\title{
Bildung und Erziehung im Kontext globaler Transformationen
}

Iris Clemens, Sabine Hornberg,

Marco Rieckmann (Hrsg.)

Schriftenreihe

Ökologie und Erziehungswissenschaft der Kommission Bildung für nachhaltige Entwicklung der DGfE

DEE Deutsche Gesellschaft 
Schriftenreihe

„Ökologie und Erziehungswissenschaft"“ der Kommission

Bildung für nachhaltige Entwicklung der Deutschen Gesellschaft für

Erziehungswissenschaft (DGfE) 
Iris Clemens

Sabine Hornberg

Marco Rieckmann (Hrsg.)

Bildung und Erziehung im Kontext globaler Transformationen

Verlag Barbara Budrich

Opladen • Berlin • Toronto 2019 
Bibliografische Information der Deutschen Nationalbibliothek

Die Deutsche Nationalbibliothek verzeichnet diese Publikation in der Deutschen Nationalbibliografie; detaillierte bibliografische Daten sind im Internet über http://dnb.d-nb.de abrufbar.

Die frei zugängliche digitale Publikation wurde ermöglicht mit Mitteln des BMBF Projektes OGeSoMo der Universitätsbibliothek Duisburg-Essen. In diesem Projekt wird Open Access für geistes- und sozialwissenschaftliche Monografien gefördert und untersucht.

Informationen und Ergebnisse finden Sie unter: https://www.uni-due.de/ogesomo

(C) 2019 Dieses Werk ist bei der Verlag Barbara Budrich GmbH erschienen und steht unter der Creative Commons Lizenz Attribution-ShareAlike 4.0 International (CC BY-SA 4.0): https://creativecommons.org/licenses/by-sa/4.0/

Diese Lizenz erlaubt die Verbreitung, Speicherung, Vervielfältigung und Bearbeitung bei Verwendung der gleichen CC-BY-SA 4.0-Lizenz und unter Angabe der UrheberInnen, Rechte, Änderungen und verwendeten Lizenz.

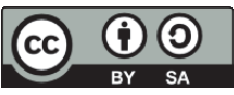

Dieses Buch steht im Open-Access-Bereich der Verlagsseite zum kostenlosen Download bereit (https://doi.org/10.3224/84742174).

Eine kostenpflichtige Druckversion kann über den Verlag bezogen werden. Die Seitenzahlen in der Druck- und Onlineversion sind identisch.

$$
\begin{array}{ll}
\text { ISBN } & 978-3-8474-2174-0 \text { (Paperback) } \\
\text { eISBN } & 978-3-8474-1201-4 \text { (eBook) } \\
\text { DOI } & 10.3224 / 84742174
\end{array}
$$

Druck: paper \& tinta, Warschau

Printed in Europe

Umschlaggestaltung: Bettina Lehfeldt, Kleinmachnow - www.lehfeldtgraphic.de Typographisches Lektorat: Anja Borkam, Jena - kontakt@lektorat-borkam.de 


\section{Inhalt}

Abkürzungsverzeichnis

$1 \quad$ Einleitung

Iris Clemens, Sabine Hornberg, Marco Rieckmann.

2 Education for Sustainable Development in the Postcolonial

World: Towards a transformative agenda

Leon Tikly.

3 Beiträge einer Bildung für nachhaltige Entwicklung zum Erreichen der Sustainable Development Goals -

Perspektiven, Lernziele und Forschungsbedarfe

Marco Rieckmann

4 Nationales Monitoring von BNE - Stand und Prozess der

Verbreitung von BNE in Deutschland

Mandy Singer-Brodowski, Nadine Etzkorn, Antje Brock, Theresa

Grapentin-Rimek, Janne von Seggern

5 Kompetenzen für eine Nachhaltige Entwicklung konzeptionelle Präzisierung der Nachhaltigkeitskompetenz über den Leistungsanspruch

Corinne Ruesch Schweizer.

6 Nahtstellen nachhaltigen globalen Lernens - Philosophieren als (neue) Aufgabe von Unterricht Lydia Kater-Wettstädt

7 Rethinking the "Global Good" of Compulsory Schooling Combining Young People's Education and Work for Making a Future in South-West Ethiopia

Sabrina Maurus 141 
8 Wege der Transmission von Bildungskonzepten in einer globalisierten Welt. Das Beispiel der Transformation des National Achievement Surveys in Indien

Theresa Vollmer

9 Europa zum Thema machen?! - Zur Konzeption von Unterrichtsmodulen für die Sekundarstufe Marie Zipp-Timmer, Nadine Sonnenburg, Sabine Hornberg, Saphira Shure

10 Europäisierungsprozesse als Reformchance? Eine institutionelle Analyse der Durchlässigkeitsstrukturen zwischen Berufs- und Hochschulbildung in Deutschland von 1990-2012

Nadine Bernhard 179

11 Learning Morality? Über die Notwendigkeit (der Vermittlung) von Normen und Werten im Kontext globaler Transformationen Matthias Huber

12 Die ,gute Schule“ im Schulwahldiskurs von Eltern an einer hizmet-inspirierten Schule

Thomas Geier, Magnus Frank, Dorothea Schmidt

13 Medien - Politik - Erziehungswissenschaft? Platzierung und De-Platzierung von Experten in globalen Wissensregimen Sarah Schaufler.

14 Rethinking education in times of globalization - but where to start the rethinking?

Iris Clemens, Tanu Biswas.

Verzeichnis der Autorinnen und Autoren 251 


\section{Abkürzungsverzeichnis}

$\begin{array}{ll}\text { ACER } & \text { Australian Council for Educational Research } \\ \text { AfDB } & \text { African Development Bank } \\ \text { ANC } & \text { African National Congress } \\ \text { AU } & \text { African Union } \\ \text { AUC } & \text { African Union Commission } \\ \text { BIBB } & \text { Bundesinstitut für Berufsbildung } \\ \text { BMBF } & \text { Bundesministerium für Bildung und Forschung } \\ \text { BNE } & \text { Bildung für nachhaltige Entwicklung } \\ \text { CESA } & \text { Continental Education Strategy for Africa } \\ \text { DEME } & \text { Department of Educational Measurement and Evaluation } \\ \text { DFID } & \text { Department for International Development } \\ \text { DGB } & \text { Deutscher Gewerkschaftsbund } \\ \text { DGfE } & \text { Deutsche Gesellschaft für Erziehungswissenschaft } \\ \text { DIHK } & \text { Deutsche Industrie- und Handelskammertag } \\ \text { DPEP } & \text { District Primary Education Programme } \\ \text { DQR } & \text { Deutscher Qualifikationsrahmen } \\ \text { EG } & \text { Europäische Gemeinschaft } \\ \text { ELIN } & \text { Projekt „Europa in der Schule - Lehrerfortbildungen in Nord- } \\ & \text { rhein-Westfalen“ } \\ \text { EPAs } & \text { Einheitliche Prüfungsanforderungen in der Abiturprüfung } \\ \text { ETS } & \text { Educational Testing Service } \\ \text { ESD } & \text { Education for Sustainable Development } \\ \text { ESD } & \text { Educational Survey Division } \\ \text { EU } & \text { Europäische Union } \\ \text { FD } & \text { Agenda 2063 Framework Document: The Africa we want } \\ \text { GCED } & \text { Global Citizenship Education } \\ \text { GDP } & \text { Gross Domestic Product } \\ \text { HBNE } & \text { Hochschulbildung für eine nachhaltige Entwicklung } \\ \text { HCT } & \text { Human Capital Theory } \\ \text { HRK } & \text { Hochschulrektorenkonferenz } \\ \text { ICT } & \text { Information and Communications Technology } \\ \text { ILO } & \text { International Labour Organization } \\ \text { IMF } & \text { International Monetary Fund } \\ \text { INGO } & \text { International Non-Gonvernmental Organization } \\ \text { IRT } & \text { Item-Response-Theorie } \\ \text { KMK } & \text { Kultusministerkonferenz } \\ \text { MDGs } & \text { Millennium Development Goals } \\ & \\ & \end{array}$


MSW

NAP

NAS

NCERT

NEPAD

NGO

NPCA

NUEPA

OAU

RMSA

SAPS

SD

SDGs

SEL

SIIVE

SO

SSA

STEM

SWAPO

TCA

TCF

TSA

TVET

UIS

UN

UNECA

VIE

WAP

WTO

WWA
Ministerium für Schule und Weiterbildung NordrheinWestfalen

Nationaler Aktionsplan Bildung für nachhaltige Entwicklung

National Achievement Survey

National Council of Educational Research and Training

New Partnership for Africa's Development

Non-Gonvernmental Organization

Planning and Coordinating Agency

National University of Educational Planning and Administration

Organisation of African Unity

Rashtriya Madhyamik Shiksha Abhiyan

Stabilisation and Structural Adjustment Polices

Sustainable Development

Sustainable Development Goals

Sozial-Emotionales-Lernen

Sektion Interkulturelle und International Vergleichende

Erziehungswissenschaft

Strategic Objective

Sarva Shiksha Abhiyan

Science, Technology, Engineering and Mathematics

South West African People's Organisation

Technical Cooperation Agency

Technical Cooperation Fund

Technical Support Agency

Technical and Vocational Education and Training

UNESCO-Institute for Statistics

United Nations

UN Economic Commission for Africa

Vergleichende und Internationale Erziehungswissenschaft

Weltaktionsprogramm Bildung für nachhaltige Entwicklung

World Trade Organization

Word Without Anger 


\title{
1 Einleitung
}

\author{
Iris Clemens, Sabine Hornberg, Marco Rieckmann
}

\subsection{Die Tagung „Bildung und Erziehung im Kontext globaler Transformationen"}

Globale Veränderungen stellen Gesellschaften derzeit vor große Herausforderungen. Hierzu zählen Globalisierungs-, Internationalisierungs- und Transnationalisierungsprozesse genauso wie Migration und Flucht. In der Erziehungswissenschaft werden diese gesellschaftlichen Entwicklungen und damit oftmals einhergehenden Dilemmata bereits seit längerem in den Teildisziplinen Bildung für nachhaltige Entwicklung (BNE) und Vergleichende und Internationale Erziehungswissenschaft (VIE) aufgegriffen.

Für eine fokussierte und thematisch breite Bearbeitung dieses Themenkomplexes haben die beiden Kommissionen BNE und VIE in der Sektion Interkulturelle und International Vergleichende Erziehungswissenschaft (SIIVE) der Deutschen Gesellschaft für Erziehungswissenschaft (DGfE) am 23. und 24. März 2017 an der Universität Bayreuth eine gemeinsame Jahrestagung unter dem Titel „Bildung und Erziehung im Kontext globaler Transformationen" durchgeführt.

Höhepunkte der Tagung waren nicht nur die Hauptvorträge von Arjen Wals von der Wageningen University in den Niederlanden zu dem Thema „Disrupting the normalisation of unsustainability: rethinking education and research in times of global systemic dysfunction" und von Leon Tikly, University of Bristol, England, der sich mit "Quality learning for all and sustainable development: A transformative agenda" beschäftigte, sondern auch eine Podiumsdiskussion über Hochschulbildung und Wissenschaft in der Entwicklungszusammenarbeit. Organisiert von Christel Adick (RuhrUniversität Bochum) waren als Teilnehmende Christoph Hansert (DAAD), Ulrike Wiegelmann (GIZ GmbH), Annette Scheunpflug (Universität Bamberg) und Karsten Speck (CERM-ESA/Universität Oldenburg) geladen. Zum besonderen Charakter der Tagung hat auch ihre Anbindung an den AfrikaForschungsschwerpunkt der Universität Bayreuth beigetragen, die Raum für interdisziplinären Austausch bot. Die sehr anregende und produktive Veran- 
staltung endete nach insgesamt neun Sessions und acht Panels mit bleibenden Eindrücken und neuen Ideen.

\subsection{Hintergrund}

Das Tagungsthema wurde wie viele andere Veranstaltungen und Publikationen in den letzten Jahren unter dem Eindruck zunehmender globaler Verflechtungen gewählt. Und aus einer der vielen kontingenten Perspektiven ist dies auch durchaus plausibel. Tritt man jedoch einen Schritt zurück und reflektiert die eigenen, scheinbar selbstverständlichen Hinsichten auf Welt, werden gleich mehrere blinde Flecken deutlich, von denen zwei genannt werden sollen.

Da ist zunächst die Konzeption von Transformation selbst. Ein Kontext globaler Transformationen suggeriert, dass es auch einen Kontext, ein soziales Gebilde ohne Transformationen geben könnte. Als sei die Transformation die Abweichung, die es zu erklären gilt, anstatt die Norm. Es zeigt sich hier eine typische Fokussierung auf das Gleichwicht, die Kontinuität und Konsistenz. Aber schon Darwin hat nicht ohne Grund darauf hingewiesen, dass es strenggenommen evolutionsbiologisch noch nicht einmal Sinn macht, überhaupt von Arten zu sprechen. Umso mehr gilt für das Soziale, dass es keinen Stillstand gibt, und wenn doch, dass auch Konservation der (oft immensen) Arbeit bedarf. Dies ist eine zutiefst im nordamerikanisch-europäischen Denken verankerte Vorstellung, des Dinges an sich', wie der Philosoph Hans Vaihinger in seiner Philosophie des Als Ob 1922 deutlich macht:

„Wir bringen das Allgemeine unter die beliebte Substanzkategorie, fassen es als Ding mit Eigenschaften und Kräften. Der unkritische Sprachgebrauch hat aus dem alles personifizierenden Kindeszeitalter der Menschheit diese Redeweise mit herübergenommen: wie der Astronom noch vom Auf- und Untergang der Sonne spricht, so wenden auch wir jene bequemen Hilfsausdrücke, die Allgemeinbegriffe an, als ob das Allgemeine wirklich etwas Existierendes wäre.“(Vaihinger 1922, S. 212/214)

Man solle jedoch nicht Ernst aus diesem zugegebenermaßen sehr brauchbaren Spiel machen ,und das Als ob nicht in ein starres Daß verwandeln“ (ebd.). Es mag auch Teil des Problems derzeitiger politischer scheinbarer Rückbesinnungsrhetoriken oder Konservierungsphantasmen sein, dass Teile der Gesellschaft eine real betrachtet extrem kurze historische Spanne von gerade einmal ca. 70 Jahren Nachkriegszeit als unumstößliches und unverändertes Nationalkonstrukt und,Gesellschaftsding an sich' nimmt, statt von Transformation als selbstverständlichem Zustand aller sozialen Konstellationen auszugehen. Insofern gilt es umso mehr danach zu fragen, was die derzeitig ablaufenden Transformationen spezifisch auszeichnet. 
Das bringt uns zu dem zweiten Aspekt der Globalisierung. Auch hier lohnt ein Perspektivwechsel. Mit Bezug auf Bildung und ihre Institutionen werden Globalisierung und weltweite Vernetzung in unserem Kontext seit einiger Zeit als virulent wahrgenommen und beschäftigen Semantiken aller erziehungswissenschaftlichen Bereiche. Auch die gesellschaftlichen Verschiebungen im Zuge der Globalisierung haben im europäischen und nordamerikanischen Kontext längst die meisten Menschen selbst in nichturbanen, eher traditionellen Milieus erreicht und werden insbesondere dort als potentiell irritierend und verunsichernd bis latent verängstigend wahrgenommen. Aber auch hier ist der Fokus zumeist auf einen eher kleinen Bereich der Weltgesellschaft gerichtet. Bei einer etwas distanzierteren Betrachtung fällt jedoch auf, dass viele Menschen außerhalb Europas und Nord-Amerikas schon sehr viel früher und vor allem tiefgreifender von den Auswirkungen der teils dramatischen Veränderungen durch Globalisierungsprozesse betroffen waren. Viele Gesellschaften und mit ihnen ihre Bildungsinstitutionen sind schon seit Jahrhunderten globalen Transformationen ausgesetzt, indem Länder etwa kolonialisiert, marginalisiert oder anderweitig heftigen, von außen herangetragenen Transformationen ausgesetzt waren und beispielsweise ihre Bildungsinstitutionen zerstört oder bis zur Unkenntlichkeit desavouiert wurden. Überspitzt formuliert könnte man also sagen, diese Gesellschaften sind uns historisch betrachtet in der Erfahrung mit globalen Transformationen weit voraus. So gesehen sind es heute die Länder des sogenannten Westens, die einen Nachholbedarf in Sachen Globalisierung und der Verarbeitung der damit einhergehenden Konsequenzen haben, wobei diese vergleichsweise noch als schwach angesehen werden müssen. Ein Schwerpunkt der Tagung lag deshalb auf Kontexten jenseits von Europa und Nordamerika - aufgrund der besonderen Ausrichtung der Universität Bayreuth als Tagungsort speziell auf dem afrikanischen Kontext und Indien -, um einen alternativen Umgang mit Globalisierungsdynamiken im Bildungsbereich stärker in den Blick zu nehmen.

Analog zu politischen, ökonomischen, ökologischen, sozialen und kulturellen Globalisierungsprozessen haben sich bereits bestehende Problematiken wie Ungleichheit, Exklusion, Vulnerabilität, Diskriminierung und Gewalt trotz Empowerment und erweiterten Zugängen zu Bildung verstärkt; parallel zu globalen Migrations- und Fluchtbewegungen nehmen kulturelle und religiöse Intoleranz, identitäre Abgrenzungsbewegungen und damit verbundene politische Mobilisierungen zu, wie die UNESCO (2015) in ihrem Bericht Rethinking Education konstatiert. Globale Transformationen wie die genannten, haben in den vergangenen Jahrzehnten sowohl in westlichen als auch in nicht-westlichen Kontexten Menschen in urbanen wie in eher traditionellen Milieus erreicht. Vor diesem Hintergrund stellt sich die Frage, wie Bildungssysteme mit diesen Herausforderungen umgehen. Die UNESCO formuliert in diesem Zusammenhang gar: „Rethinking the purpose of education and the 
organization of learning has never been more urgent" (UNESCO 2015, S. 10).

Hieran anknüpfend eröffnete die Tagung einen Raum für die Reflexion ausgewählter Aspekte des Globalen Wandels sowie für seine erziehungswissenschaftlichen Bearbeitung. Sie thematisierte in diesem Kontext u.a. folgende Fragen: Was ist das Spezifische der derzeitigen, globalen Transformationen, und welche Rolle spielt Bildung bzw. kann sie spielen? Welche Bedeutung haben globale und alternierende Gesellschaftskonzeptionen für humanistische Bildungsideale? Welchen Stellenwert gewinnen lebenslange Lernprozesse bei der Verortung von migrations- und fluchtgeprägten Bildungsbiografien in unterschiedlichen Bildungssystemen? Welche Risiken, aber auch Chancen und Möglichkeiten bergen Prozesse der Internationalisierung, Globalisierung und Transnationalisierung für nationale Bildungswesen? Und schließlich: Wie kann Bildung besser auf die Herausforderungen einer nachhaltigen Entwicklung reagieren?

\subsection{Beiträge in diesem Band}

Im vorliegenden Band werden ausgewählte Vorträge der Tagung veröffentlicht. Damit wird ein Einblick in aktuelle Forschungen zu Bildung und Erziehung im Kontext globaler Transformationen der wissenschaftlichen Community und allen Interessierten zugänglich gemacht.

Im ersten Beitrag ,Education for Sustainable Development in the Postcolonial World: Towards a transformative agenda" befasst sich Leon Tikly mit einer Analyse und Kritik aktueller regionalpolitischer Agenden in Afrika, nämlich dem „Agenda 2063 Framework Document: The Africa We Want“ der Afrikanischen Union und der begleitenden „Continental Education Strategy for Africa“ (CESA). Diese Dokumente haben den Anspruch, eine transformative Vision für nachhaltige Entwicklung bzw. Bildung für nachhaltige Entwicklung darzulegen, die mit einer panafrikanischen Vision eines vereinten und wohlhabenden Afrikas verbunden ist.

In „Beiträge einer Bildung für nachhaltige Entwicklung zum Erreichen der Sustainable Development Goals (SDGs) - Perspektiven, Lernziele und Forschungsbedarfe" setzt sich Marco Rieckmann mit der Frage auseinander, welche Rolle Bildung für nachhaltige Entwicklung für das Erreichen der Sustainable Development Goals (SDGs) der Vereinten Nationen spielen kann. Auf die Relevanz einer handlungsorientierten, transformativen Pädagogik wird genauso eingegangen wie auf Forschungsbedarfe im Kontext von Bildungsprozessen für die SDGs.

Mandy Singer-Brodowski, Nadine Etzkorn, Antje Brock, Theresa Grapentin-Rimek und Janne von Seggern widmen sich in ihrem Beitrag ,Natio- 
nales Monitoring von BNE - Stand und Prozess der Verbreitung von BNE in Deutschland" der Konzeption dieses BNE-Monitoring in Deutschland sowie ausgewählten Ergebnissen einer Dokumentenanalyse und einer groß angelegten Interviewstudie. Sie geben damit einen Überblick zur BNE-Verankerung in den verschiedenen Bereichen des deutschen Bildungssystems. Es wird deutlich, dass die Verankerung von BNE sehr stark zwischen den einzelnen Bundesländern, aber auch zwischen den verschiedenen Bildungsbereichen variiert.

In ihrem Beitrag „Kompetenzen für eine Nachhaltige Entwicklung - konzeptionelle Präzisierung der Nachhaltigkeitskompetenz über den Leistungsanspruch" erörtert Corinne Ruesch Schweizer, welche Entscheidungsgrundlage durch eine Präzisierung von Nachhaltigkeitskompetenz zu schaffen ist, damit diese begründete Entscheidungen für die didaktische Gestaltung eines Studienangebots ermöglicht. Dazu wird gefragt, wie die Präzisierung der Nachhaltigkeitskompetenz aus einer didaktischen Erkenntnisperspektive konzeptualisiert werden kann und welche Befunde aus der Forschung zur Hochschulbildung für eine nachhaltige Entwicklung als Entscheidungsgrundlage für die Präzisierung eines Leistungsanspruchs dienen können.

Mit ihrem Beitrag ,Nahtstellen nachhaltigen globalen Lernens - Philosophieren als (neue) Aufgabe von Unterricht " nähert sich Lydia KaterWettstädt der Frage, wo es Ansatzpunkte für ein Umdenken und eine aktive Umgestaltung gibt, die es Kindern und Jugendlichen ermöglichen, sich in einer Weltgesellschaft kritisch-reflexiv zu verorten und aktiv gestaltend mitzuwirken, auf der Ebene von Unterricht an und stellt auf der Basis empirischer Befunde zur Auseinandersetzung von Jugendlichen mit globalen Fragestellungen Überlegungen zu einer Veränderung der Unterrichts- und damit auch der Schulpraxis an. Dabei wird Philosophieren als ein besonders relevanter methodischer Zugang beleuchtet.

Sabrina Maurus lotet in ihrem Beitrag ,,Rethinking the ,Global Good' of Compulsory Schooling - Combining Young People's Education and Work for Making a Future in South-West Ethiopia", der sich auf ihre ethnographische Feldforschung im Hamar Destrikt in Äthiopien stützt, die Spannungen und Paradoxa aus, die sich durch die Durchsetzung der allgemeinen Schulpflicht in durch Subsistenzwirtschaft geprägten ländlichen Gesellschaften ergeben. Die Spezifik lokaler Ökonomien und entsprechende besondere Lernerfordernisse der Angehörigen fordern die Idee einer allgemeinen Schulpflicht und herkömmliche Curricula heraus, und Schule erweist sich hier mindestens in Teilen als dysfunktional. Die Notwendigkeit, neue Konzeptionen von Lernen und dessen Organisation zu entwerfen, wird offensichtlich.

In ,, Wege der Transmission von Bildungskonzepten in einer globalisierten Welt. Das Beispiel der Transformation des National Achievement Surveys in Indien " zeigt Theresa Vollmer anhand des Beispiels der Transformation des National Achievement Surveys (NAS) in Indien, wie global kursierende 
Bildungskonzeptangebote - konkret die Item-Response-Theorie (IRT), die Anwendung in der PISA-Studie der OECD findet - lokal aufgegriffen und prozessiert werden. Es geht ihr darum, anhand der trading zones of knowledge und unter Einbeziehung netzwerktheoretischer Positionen Transformationen von Bildungskonzepten in den globalen Kontext zu stellen. Es sollen möglichst viele Akteure sowie deren Interdependenzen in die Analyse der Transformationen von Bildung einbezogen werden, um die Struktur und Dynamik der internationalen Verflechtung der Bildungsakteure zu erforschen.

Mit ihrem Beitrag ,Europa zum Thema machen?! - Zur Konzeption von Unterrichtsmodulen für die Sekundarstufe " gehen Marie Zipp-Timmer, Nadine Sonnenburg, Sabine Hornberg und Saphira Shure am Beispiel von Unterrichtsmodulen für die Sekundarstufe I der Frage nach, wie europabezogene Themen stärker und optimaler im Hinblick auf die Interessen von Schülerinnen und Schülern in den regulären Unterricht gesellschafts- und sozialwissenschaftlicher Fächer integriert werden können und damit zugleich ein Beitrag zur Förderung einer kritischen, konstruktiven Reflexion von Europa geleistet werden kann.

In ihrem Beitrag „,Europäisierungsprozesse als Reformchance? Eine institutionelle Analyse der Durchlässigkeitsstrukturen zwischen Berufs- und Hochschulbildung in Deutschland von 1990-2012" zeigt Nadine Bernhard, welchen Einfluss die europäischen Bildungsprozesse Bologna-Prozess für die Hochschulbildung und der Kopenhagen-Prozess für die berufliche Bildung in Hinblick auf die Entwicklung institutioneller Durchlässigkeitsstrukturen in Deutschland hatten. Mithin geht es um die Frage, inwiefern Europäisierungsprozesse auch als Chance genutzt werden konnten, um die deutsche traditionelle Trennung zwischen Berufs- und Hochschulbildung $\mathrm{zu}$ verringern und Übergänge zu erleichtern.

In seinem Beitrag ,Learning Morality? Über die Notwendigkeit (der Vermittlung) von Normen und Werten im Kontext globaler Transformationen" beschäftigt sich Matthias Huber unter anderem mit Rekurs auf die Sustainable Development Goals (SDGs) der United Nations mit Global Education und Global Citizenship und mit darüber hinaus weiterführenden Fragen, die im Kontext der Moralerziehung angesiedelt sind.

In ihrem Beitrag „,Die ,gute Schule“ im Schulwahldiskurs von Eltern an einer hizmet-inspirierten Schule" beschäftigen sich Thomas Geier, Magnus Frank und Dorothea Schmidt mit dem Schulwahlverhalten von Eltern, deren Kinder eine der insgesamt 26 hizmet-inspirierten Schulen in Deutschland besuchen. Dabei steht im Fokus die Frage danach, wie die Eltern dieser Schüler*innen zu der Entscheidung gelangt sind, dass diese Schule die beste für ihr Kind sein würde. Der Aufsatz entstand im Kontext des DFG-Projekts „Die Pädagogik der Gülen-Bewegung“, in dessen Zuge seit Oktober 2016 die Praxis religiöser Gesprächskreise (sohbetler) im Kontext der sogenannten 
Gülen-Bewegung und ihre biographische Relevanz für die Teilnehmenden untersucht wird.

In dem Beitrag „Medien - Politik - Erziehungswissenschaft? Platzierung und De-Platzierung von Experten in globalen Wissensregimen " nimmt Sarah Schaufler die veränderten Verhältnisse von Politik, Medien und Wissenschaft in den Blick, um ihre Neu-Kalibrierung und die Entstehung neuer Grenzen nachzuzeichnen, an denen sich wiederum neue Akteure, wie Expert*innen, anlagern. Vor diesem Hintergrund wird die besondere Bedeutung von Medien als Mittler dieser Expertise zwischen Wissenschaft und Politik in den Blick genommen. Zudem wird die Position der Erziehungswissenschaft zwischen öffentlichem und disziplinärem Interesse skizziert und ihre Platzierung in medialen Diskussionen an einem empirischen Beispiel beschrieben.

In dem Beitrag ,,Rethinking education in times of globalization - but where to start the rethinking?" fragen Iris Clemens und Tanu Biswas danach, wo eine kritische Reflexion aktueller Vorstellungen von Bildung - insbesondere das derzeit dominante, spezifische Konzept von Schule -beginnen müsste. Die Grundannahme einer universellen Bildung, die global für alle funktional und gültig sei, wird hinterfragt und das für den euro-nordamerikanischen Kontext scheinbar typische Denken in Singularitäten selbst als Teil des Problems identifiziert. Anhand des Modebegriffs der employability wird dies vor allem anhand des indischen Kontextes konkretisiert, indem problematisiert wird, inwieweit dieses Konzept überhaupt einer universellen sozialen Realität entspricht. Die Autorinnen plädieren für Pluralitäten und Simultanitäten bei Bildungsentwürfen.

Wir danken allen Autor*innen für die Mitwirkung an der Tagung und insbesondere für die Aufbereitung der Beiträge für diesen Sammelband. Gedankt sei zudem den Kommissionen BNE und VIE für die Finanzierung dieser Veröffentlichung. Wir hoffen, mit diesem Sammelband wertvolle Anregungen für eine weitere wissenschaftliche Auseinandersetzung mit Bildung und Erziehung im Kontext globaler Transformationen zu geben.

\section{Literatur}

UNESCO (United Nations Educational, Scientific and Cultural Organization) (2015): Rethinking Education. Towards a global common good? Paris: UNESCO. http://unesdoc.unesco.org/images/0023/002325/232555e.pdf 18.05.2018].

Vaihinger, Hans (1922): Die Philosophie des Als Ob. Leipzig: Felix Meiner. 



\title{
2 Education for Sustainable Development in the Postcolonial World: Towards a transformative agenda
}

\author{
Leon Tikly
}

\subsection{Introduction}

The aim of the paper is to offer an analysis and critique of recent regional policy agendas in Africa, namely the African Union's Agenda 2063 Framework Document: The Africa We Want (AUC 2015) and the accompanying Continental Education Strategy for Africa (CESA) (AU 2015). The documents claim to set out a transformative vision for Sustainable Development (SD) and for Education for Sustainable Development (ESD) respectively, linked to a pan-African vision of a united and prosperous Africa. SD and ESD have achieved a hegemonic status as global discourses thanks to the adoption of the Sustainable Development Goals (SDGs).

A focus on the African continent in relation to an analysis of SD and ESD seems particularly relevant given the scale of the challenges facing the subcontinent in achieving the SDGs. The documents are analysed in relation to an understanding of the 'postcolonial condition'. This involves a consideration of the colonial legacy but also of Africa's position in relation to processes of contemporary globalisation. The analysis takes place across six domains of the economy, the polity and of violence, as well as the social, cultural and environmental domains. It will be argued that the documents do not pay sufficient attention to the role that education has played since colonial times in supporting unsustainable development and, that the documents present contradictory understandings about the nature of SD and ESD in which narrow economic concerns predominate, reflecting the interests of global powers and regional elites. The paper concludes by setting out the basis for a transformative ESD that grounded in a vision of social and environmental justice. 


\subsection{Agenda 2063 and CESA}

This section provides a brief overview of the two key policy texts to be considered, namely the Agenda 2063 Framework Document: The Africa we want (FD for short) which sets out in detail the aspirations for SD on the continent and the underlying view of the opportunities and challenges in realising these aspirations $^{1}$; and, the CESA document which sets out an educational strategy commensurate with Agenda 2063. In order to understand how ESD is conceptualised, it is important to consider the two documents in relation to each other starting with the FD.

\subsubsection{Agenda 2063: Towards the Africa we want}

The Agenda 2063: The Africa we Want recently adopted by the African Union sets out an aspirational 50-year programme of action for the continent framed within an over-arching commitment to pan-Africanism, inclusive growth, sustainable development and a vision of an African Renaissance ${ }^{2}$. The vision is for "an integrated, prosperous and peaceful Africa, driven by its own citizens and representing a dynamic force in the international arena" (AU 2015, p. iv). It is based on a recognition of the enormous wealth of the continent in natural resources and the resilience and cultural resourcefulness of African peoples. In highlighting the opportunities as well as the challenges faced by the continent in developmental terms, Agenda 2063 stands in contrast to the more pessimistic accounts on development in Africa prevalent in the international development arena. The document is also based on an analy-

1 Agenda 2063 consists of three components, namely the vision for 2063 based on the Aspirations of the African People, a transformation framework or framework document which presents detailed milestones, goals, priority areas, targets and indicative strategies; and an implementation plan. It is the Agenda 2063: The Africa We Want Framework Document (AU 2015a) that has provided the major focus for this paper as it sets out in some detail the nature of the development challenges and opportunities facing the continent.

2 The origins of Agenda 2063 lie in the Golden Jubilee of the Organisation of African Unity (OAU) now the African Union (AU). The AU summit tasked the African Union Commission (AUC), supported but the New Partnership for Africa's Development (NEPAD), the Planning and Coordinating Agency (NPCA), the African Development Bank (AfDB) and the UN Economic Commission for Africa (UNECA) to prepare a 50-year continental agenda. This was to be achieved through an extensive consultative process involving a series of meetings across the continent with stakeholders spanning many areas of African society including youth, women, civil society organisations, the diaspora, African think tanks and research institutes, planners, the private sector, religious organisations, the Forum for Former African Heads of State and others. This gave rise to the Aspirations of the African People, the driver of Agenda 2063. 
sis of previous development experiences and initiatives. Specifically, it locates itself within the history of pan-Africanism and as part of a continuum on previous African-led development initiatives including the formation of the OAU, its subsequent transformation to the AU, the Monrovia declaration and the Lagos Plan of Action. Agenda 2063 also refers to externally driven development agendas. Prominent amongst these are the structural adjustment programmes introduced under the auspices of the World Bank during the 1980s, the Millennium Development Goals (MDGs) and the Sustainable Development Goals (SDGs). An important point of reference is the 'success stories' of the South East Asian 'tiger' economies to which several references are made. Some of the key opportunities and challenges set out in the document are discussed in later sections of the paper.

The FD outlines the 'aspirations' set out in Agenda 2063. These are (AUC 2015):

A prosperous Africa based on inclusive growth and sustainable development. Key to this priority is the eradication of poverty in one generation and building, sharing prosperity through social and economic transformation and with the means and resources to drive its own development. This includes sustainable and long term stewardship of its resources where African people have a high standard of living, and quality of life, sound health and wellbeing; well-educated and skilled citizens, underpinned by science, technology and innovation for a knowledge society and where no child misses school due to poverty or any form of discrimination; cities and other settlements are hubs of cultural and economic activities; economies are structurally transformed to create shared growth, decent jobs and economic opportunities; modern agriculture for increased production, productivity and value addition contributes to prosperity and Africa's collective food security; and, Africa's unique natural endowments, its environment and ecosystems, including its wildlife and wild lands are healthy, valued and protected, with climate resilient economies and communities.

An integrated continent, politically united and based on the ideals of PanAfricanism and the vision of Africa's Renaissance. This involves creating a United Africa; a world class, integrative infrastructure that criss-crosses the continent; dynamic and mutually beneficial links with her Diaspora; and, a continent of seamless borders.

An Africa of good governance, democracy, respect for human rights, justice and the rule of law. Priorities here include Africa being a continent where democratic values, culture, practices, universal principles of human rights, gender equality, justice and the rule of law are entrenched; and, where there are capable institutions and transformative leadership in place at all levels.

A peaceful and secure Africa. Priorities include a culture of peace and tolerance nurtured in Africa's children and youth through peace education; the 
more effective management of diversity; developing an entrenched and flourishing culture of human rights, democracy, gender equality, inclusion and peace; prosperity, security and safety for all citizens; and, mechanisms to promote and defend the continent's collective security and interests.

An Africa with a strong cultural identity, common heritage, shared values and ethics. The FD states that Pan-Africanism and the common history, destiny, identity, heritage, respect for religious diversity and consciousness of African people's and her diaspora's will be entrenched and the African Renaissance has reached its peak by 2063.

An Africa whose development is people-driven, relying on the potential of African people, especially its women and youth, and caring for children. This is based on a vision that all the citizens of Africa will be actively involved in decision making in all aspects including social, economic, political and environmental and where Africa shall be an inclusive continent where no child, woman or man will be left behind or excluded, on the basis of gender, political affiliation, religion, ethnic affiliation, locality, age or other factors.

Africa as a strong, united and influential global player and partner. The FD affirms the importance of African unity and solidarity in the face of continued external interference including, attempts to divide the continent and undue pressures and sanctions on some countries.

\subsubsection{Continental Education Strategy for Africa}

The Continental Education Strategy for Africa 2016-2025 (CESA) (AU 2015) was developed under the auspices of the African Union. It provides continuity on the central role accorded to education in Agenda 2063. Developing the priorities identified by African Ministers of Education set out in the Kigali Declaration that fed into the SDGs consultation process, it can also be seen as a regional response to the education SDG. As such it presents an overall vision of African-led ESD and a set of regional priorities for implementing ESD in a way that is consistent with the Pan-African vision of an African Renaissance. Like the FD, the CESA sets out a series of challenges facing education and these are discussed in more detail in later sections. At a general level, it notes that whilst there has been progress with enrolments since the advent of the MDGs, there remain an estimated 30 million children that are unschooled in Africa and their number is growing due to rapid population growth. There is also an imbalance in enrolments across sectors with a broad base $(79 \%$ at primary level), a very narrow middle section $(50 \%$ at secondary level) and a miniscule top (7\% at tertiary education). Further, expansion in enrolments also masks huge disparities and system dysfunctionalities and inefficiencies across sub-sectors. Key sub-sectors such as preprimary, technical and vocational and non-formal education are severely 
underdeveloped in spite of growing evidence showing their importance. The African education and training systems are also characterised by low quality of teaching and learning, inequalities and exclusion at all levels. Moreover, one of the critical issues in the education system is its segmented sub-sectors which lack articulation and complementarity. In tackling these challenges, CESA sets out the following 12 strategic objectives (AU 2015):

- SO 1: Revitalise the teaching profession to ensure quality and relevance at all levels of education;

- SO 2: Build, rehabilitate, preserve education infrastructure and develop policies that ensure a permanent, healthy and conducive learning environment in all sub-sectors and for all, so as to expand access to quality education;

- SO 3: Harness the capacity of ICT to improve access, quality and management of education and training systems;

- SO 4: Ensure acquisition of requisite knowledge and skills as well as improved completion rates at all levels and groups through harmonisation processes across all levels for national and regional integration;

- SO 5: Accelerate processes leading to gender parity and equity;

- SO 6: Launch comprehensive and effective literacy programmes across the continent to eradicate the scourge of illiteracy;

- SO 7: Strengthen the science and math curricula in youth training and disseminate scientific knowledge and culture in society;

- SO 8: Expand TVET (Technical and Vocational Education and Training) opportunities at both secondary and tertiary levels and strengthen link ages between the world of work and education and training systems;

- SO 9: Revitalise and expand tertiary education, research and innovation to address continental challenges and promote global competitiveness;

- SO 10: Promote peace education and conflict prevention and resolution at all levels of education and for all age groups;

- SO 11: Improve management of education system as well build and enhance capacity for data collection, management, analysis, communication, and use;

- SO 12: Set up a coalition of stakeholders to facilitate and support activities resulting from the implementation of CESA.

\subsection{Sustainable development and the postcolonial condition}

The aim of this section is to set out an understanding of a transformative SD and ESD that is relevant for Africa. It is argued that existing accounts of SD 
and ESD whilst offering useful insights, are insufficient for understanding the nature and causes of unsustainable development in Africa. As such they are limited in the extent to which they are able to offer a genuinely transformative agenda. Within the wider literature, SD is often conceived in terms of the three 'domains' of the economic, social and environmental although they differ in how the relationship between these domains is understood (Elliot 2013). SD is seen to arise as a consequence of positive interactions between these domains. Following the famous Brundtland commission report, Our Common Future (WCED 1987), a transformative SD is considered to be one that "meets the needs of the present without compromising the ability of future generations to meet their own needs" (WCED 1987, p. 41). Education, although a social institution, is implicated in all three domains and ESD is considered to be education that positively contributes to transformation across all three domains (Wals/Kieft 2010).

\subsubsection{The critique of dominant accounts}

At a discursive level, SD can best be understood as an example of a 'floating signifier' (Laclau 2005; Kogl/Kurze 2013). That is to say that what the term has come to signify has shifted over time and in relation to context and is slippery to define. The term has also been shaped by changing disciplinary influences and understandings of 'development'. It is also something of a 'metafix' (L.le 1991) in that it has been perceived to mean 'all things to all people' and has been used to quilt together disparate interests in the field of international development ${ }^{3}$. As Blewitt (2018) has noted, global debates about the meaning of SD involve sometimes contradictory discourses linked to differing starting assumptions and normative frameworks. For Blewitt, provided contradictions are acknowledged, this can be a source of productive tension. It is suggested below, however, that such a view does not adequately acknowledge the role of different interests linked to different forms of material and discursive power in shaping and contesting agendas. Rather, it is argued that it is necessary to be explicit about how power operates in debates about SD and ESD and about the interests involved including those linked to class, ethnicity/race and gender.

The three main discourses evident in the SDGs are those of inclusive growth linked to World Bank influence, discourses about human rights and

3 As Lélé first noted back in 1991, it has become something of a 'metafix' "that will unite everybody from the profit-minded industrialist and risk minimising subsistence farmer to the equity-seeking social worker, the pollution concerned or wild-lifer loving First Worlder, the growth-minimising policy maker, the goal-oriented bureaucrat, and therefore, the votecounting politician" (Lélé 1991, p. 613). 
environmentalism both of which are linked predominantly to UN and INGO influences. Each is centred on one of the domains although has implications for the other domains. In the context of Agenda 2063, each of these discourses is apparent along with another discourse focused on pan-Africanism. Each discourse claims to be 'transformative' albeit in different ways. All of them (with the exception of pan-Africanism) have been evident in global discourses about SD as they have evolved since the 1960s (Blewitt 2018; Elliot 2013). Each draws on and develops earlier discourses about development, but these are re-interpreted and re-positioned in relation to contemporary concerns.

The most obvious discourse on an initial reading of the documents is that of pan-Africanism. Here SD is presented principally in terms of an African Renaissance drawing on a long history of pan-Africanism on the continent. ESD is principally understood in this discourse as a vehicle for promoting African cultures, values and languages. However, the dominant version of SD in Agenda 2063 is organised around the idea of inclusive growth. This discourse presents SD principally in economic terms and centres on an ideal of growth that has the effect of reducing absolute poverty and that is achieved through the use of green technologies. The discourse follows a trajectory from previous hegemonic development discourses including modernisation theory and neoliberalism and includes ideas from environmental economics. The dominant view of ESD linked to this discourse is one that sees education principally in terms of producing human capital. Agenda 2063 also alludes to discourses on human rights in which SD is seen mainly in relation to social development and the protection and advancement of human rights. ESD in this discourse is principally concerned with expanding the right to a good quality education and linked to the realisation of the education SDG (SDG 4). Finally, there is evidence of the impact of environmentalism and this finds expression in concerns about 'environmental protection'. Globally, these are often associated with forms of environmental education (Wals/Kieft 2010) although as we will see, references to environmental education are not evident in the CESA.

There are two main criticisms of the understanding of SD and ESD contained in Agenda 2063 (and by implication in the SDGs). The first is that the three domains of the economic, social and environmental that act as a point of reference for each discourse are inadequate for capturing the range of issues and challenges facing SD in Africa. Rather, it is suggested below that consideration of the domains of the polity, civil society, violence and of culture are also necessary as these areas are crucial for understanding 'development' in Africa but are not adequately taken account of across the existing three domains. Secondly, existing accounts are insufficiently historical. In relation to the African and other postcolonial contexts, none of them, with the exception of pan-Africanism, take account of the colonial legacy (even in the 
case of pan-Africanism as it is portrayed in Agenda 2063 it will be suggested that the account is only partial). Thirdly, none of the discourses offers a sufficient conception of the underlying causal mechanisms ${ }^{4}$ that give rise to unsustainable development which, it is suggested, lie not only in the colonial legacy but in an understanding of Africa's position in relation to processes of contemporary globalisation.

\subsubsection{Towards a transformative SD and ESD}

So how might a genuinely transformative SD and ESD that is relevant for the African context be conceptualised? It is argued in this section that understanding what a transformative SD and ESD might mean requires first taking account of and then seeking to transform the deep causal mechanisms that give rise to unsustainable development. This in turn requires understanding the nature of the 'postcolonial condition' in Africa ${ }^{5}$, i.e. it requires giving consideration to the longue durée of development on the continent since colonial times as well as Africa's position on the margins of contemporary processes of globalisation. It is also argued that the postcolonial condition itself needs to be understood both discursively, i.e. in terms of the constitutive effects of different discourses of development on the way that social reality and postcolonial identities are constructed but also materially, as an aspect of the political economy of globalisation. With particular reference to Agenda 2063 and to CESA, a transformative SD and ESD needs to be rooted in an analysis of the nature of regional policy agendas. Finally, SD and ESD need to be conceptualised against an understanding of social and environmental justice which it is suggested, provides a suitable normative basis for evaluating the extent to which SD and ESD have been realised.

In developing the analysis of the postcolonial condition, the paper is informed at an ontological level by developments in inter-disciplinary understanding of complexity theory as it has been applied to the social sciences in

4 The idea of causal mechanism is taken from complex realism which informs the understanding of complex systems developed here at a metatheoretical level. As Byrne and Callaghan (2014) explain, complex realism brings together Bhaskar's critical realism with complexity theory. Put very simply the assumption is of one ontological reality comprised of complex systems albeit with differing perceptions of that reality. The task of the disciplines is to uncover the deep lying causal mechanisms that give rise to change in complex systems.

5 At the most general level the term "postcolonial condition" is used to describe a shift in the cultural, political and economic arrangements that arise from the experiences of European colonialism both in former colonised and colonising countries. Importantly, it is used not just to describe specific developments or events related to colonialism and its aftermath but also to signify an epistemological shift in the way that these events are described and interpreted (Tikly 1999). 
general (e.g. Byrne/Callaghan 2014); to an understanding of globalisation and of global crisis (Walby 2009, 2015); to debates about sustainable development (e.g. Wells 2013; Sachs 2015); public policy (Cairney 2012); aid and international development (Ramalingam 2013; Andrews et al. 2017); and, education (Mason 2008; Davies 2004). Space does not allow for a full account here. At the most basic level the understanding of complexity focuses on the idea of complex systems. It is possible to conceive of many aspects of social reality in terms of systems thinking (although not all aspects of social reality behave exhibit complex behaviour $)^{6}$. It thus provides one ontological basis for considering the co-evolution of complex systems that span the natural and social worlds and is thus relevant for considering SD and ESD which are fundamentally concerned with the relationship between social and natural systems.

The identification of what systems are relevant for consideration when discussing SD and ESD in Africa is at one level an arbitrary one and depends on the interpretation of the reality that is being analysed. In the context of this article, complex systems include 'domains' including those of the economic, the political and social domains, as well as those of civil society, violence, culture and of the environment; various 'regimes', including regimes of global governance such as those governing the environment, aid and education and regimes of inequality; discourse understood as complex systems of signification and meaning; natural systems including eco-systems; and, institutions such as health, welfare, education and training.

Key characteristics of systemic behaviour that will be referred to are that systems comprise elements that evolve in relation to each other; that complex systems demonstrate autopoiesis (i.e. they are self-generating and selfcorrecting); they exhibit positive and negative feedback loops; they also exhibit 'path dependency', i.e. periods of relative equilibrium punctuated when systems reach a 'tipping point' on account of incremental or sudden change/ crisis; that systems co-evolve in relation to each other in often antagonistic and contradictory ways; that other related systems comprise the 'fitness landscape' in relation to which systems evolve ${ }^{7}$; and, that this wider landscape is constituted by forms of material and discursive power that give rise to regimes of inequality.

6 It is possible to distinguish, for instance between complicated systems such as a sophisticated machine like a car and complex systems that demonstrate complex behaviours.

7 Systems in this understanding are not nested as is the case in traditional accounts. Rather they are free floating albeit in a fitness landscape populated by other systems in relation to which they co-evolve. 


\subsubsection{Africa, globalisation and crisis}

Recent work by Sylvia Walby $(2009,2015)$ that draws on insights from complexity theory provides a useful starting point. Like much existing scholarship on globalisation, however, the account is written from a Eurocentric perspective with little if any consideration given to the implications for the African continent. Here, insights have been re-interpreted to make them relevant for a discussion of Africa and synthesised with ideas from recent work on the political economy of Africa (e.g. Ferguson 2006; Mohan 2013; Ayers 2013).

The basic definition of globalisation referred to by Walby is taken from the seminal work of Held et al. (1999) who define globalisation as "a process (or set of processes) which embodies a transformation in the spatial organization of social relations and transactions - assessed in terms of their extensity, intensity, velocity and impact-generating transcontinental or interregional flows and networks of activity, interaction, and the exercise of power" (Held et al. 1999, p. 16). Usefully for our purposes, is that forms of globalisation have occurred before and that colonialism can be interpreted as a previous form of globalisation that has been significant in giving rise to contemporary forms ${ }^{8}$. Held et al. (1999) understand contemporary globalisation which they interpret as coinciding with the end of the Second World War and the advent of the so-called development era, as historically unprecedented in terms of its extensity, intensity, velocity and impact ${ }^{9}$.

Developing Held et al.'s argument, Walby (2009) argues that globalisation consists of uneven global flows of capital, trade, and people, an uneven development of global institutions, networks and hegemons, and global civil societal waves - not a single uniform or linear process. In the language of complexity, this is to acknowledge more than one 'path dependency' in the way that globalisation has developed leading to different development trajectories, varieties of capitalism (see also Peck/Theodore 2007), forms of the

Held et al. (1999) provide an historical periodisation of different forms of globalisation, in the pre-modern, early modern, modern and contemporary periods. They argue that international and global interconnectedness is by no means a novel phenomenon and seek to advance understanding by providing a framework for assessing the qualitative and quantitative differences between the forms taken by globalisation in different eras. Of particular relevance here is their analysis of the global flows and networks associated with modern globalisation (1859 - 1945). Here the focus is on the enormous expansion of global, political and military relations associated with Western global empires and the soaring of global trade and investment during this period.

The authors explain that by 'flows' they refer to "the movements of physical artefacts, people, symbols, tokens and information across space and time', whilst 'networks' is used to refer to 'regularized or patterned interactions between independent agents, nodes of activity, or sites of power" (Held et al. 1999, p. 16). 
state and versions of modernity itself. In Walby's work for example, she distinguishes between neo-liberal and more social democratic versions of capitalism. In the sections below, reference will be made to various development pathways in different eras including differences for example between colonialism under the French and British colonisers, different development trajectories undertaken by nations in the post-independence phase as well as differences in how development and modernity are conceived within panAfricanism itself including in Agenda 2063.

Following Walby it is argued that the development of flows, institutions, and waves involves the co-evolution of different domains including those of the economy, the polity, civil society and of violence as well as the social, cultural and the environmental domains ${ }^{10}$ - there is no simple one-way impact of the economic on the rest. Walby draws attention to the multidirectional nature of change and the importance of considering how different domains co-evolve rather than assume that change is unidirectional in nature. The upshot is that 'development' cannot be 'read off' in a simple way from any one domain such as the economic and the importance of different domains at any point in determining the direction of development pathways might shift depending on the specific conjuncture of events. Similarly, when systems reach a 'tipping point', for example in the wake of the 2007 financial crisis, the causes of the crisis are themselves multifaceted ${ }^{11}$.

Walby (2009) following Held et al. (1999) argues that contemporary globalisation essentially involves the de-territorialisation and reterritorialisation of space. That is to say, rather than the nation state or the region becoming 'irrelevant' as is suggested in some 'hyperglobalist' views of globalisation, they have been reconfigured in relation to the global scale ${ }^{12}$. As we will see, key moments in the de-/re-territorialisation of space that are of relevance for Africa include the development of a diaspora as a consequence of slavery and migration, the advent of the so-called 'development era', the rise of pan-Africanism in the context of anti-colonial struggles, the

10 Walby actually refers to the domains of economy, polity, civil society, violence and ethnicity. In the African context and in the context of a discussion about SD and ESD it was decided to organise a discussion around what seem more relevant domains.

11 This is similar to Gramsci's conception of organic crisis as involving the coming together of economic, political and cultural factors to create what might be described in popular parlance a 'perfect storm'. Thus the advent of neo-liberal policies can be seen in economic terms as a response to the debt crisis in the wake of the 1973 oil shock, in political terms as a response to Mexico's decision to default on its debt and at a cultural level as a consequence of the development of neoliberal ideas from the 1950s. Similarly, the 2008 global crisis for involved he interaction of factors within the housing market as well as related to global financial regulation.

12 Here the term 'scale' is used in preference to that of 'level' as the former sees space as the mutable product of social relations and struggle in which the global, regional and national 'levels' are mutually implicated (Verger et al. 2018). 
'hollowing out' of the state under neo-liberalism, the emergence of regional developmentalism with the formation of first the OAU and then the AU and, the impact of regimes of global environmental governance on the natural environment.

As Walby (2009) points out, contemporary globalisation is characterized by contesting global hegemons, especially the USA and the rising powers, as well as the emergence of global institutions including the Bretton Woods financial Institution and the UN system. The period since the end of the Second World War has been marked by the emergence in Gramsci's (1992) terms of a dominant 'historical bloc'13. Taking up and adapting this concept, Hoogvelt (1997) describes sub-Saharan Africa as constituting a distinctive 'postcolonial formation', i.e. a distinctive mixture of economic, political and cultural dynamics linked to Africa's position in the world and to the nature of regional responses to globalisation.

The current historical bloc has been described as representing a contradictory fusion of the politics of states and empire, that is, the United States and its allies and the interests of dominant factions of capital including transnational corporations and finance capital (Harvey 2003). World order is, however, increasingly contested. Of particular relevance for Africa, for instance is the emergence of the so-called rising powers that includes South Africa as one of the BRICS economies ${ }^{14}$. Also, relevant here are attempts to develop the African Union as a means for projecting African interests globally. As will be discussed below, however, an aspect of the postcolonial condition in Africa is the continued marginal position of African governments in relation to the global economy and processes of global governance.

Here Barnett and Duvall's (2005) work on the nature of power in international relations is considered useful supplement to Walby's ideas. The authors define power as "the production, in and through social relations, of effects that shape the capacities of actors to determine their own circumstances and fate" (Barnett/Duvall 2005, p. 3). They distinguish between different kinds of power that can help to explain change within global and regional regimes of governance. The authors define compulsory power as comprising the relations of interaction that allow one actor to have direct control over another. In the context of the focus of this book, the conditionalities imposed by donors on recipients of aid can be seen as an example of this kind of power as can the inability of low and middle-income countries to hold donor countries to account for the amount of aid provided of for the nature of the aid relationship.

At a general level this signifies the complex relationships between different actors in any historical era including those of states, multilateral organisations, different factions of capital and global civil society.

The BRICS economics comprise Brazil, Russia, India, China and South Africa. 
A second type of power is institutional power in which states design international institutions in ways that work to their long-term advantage and to the disadvantage of others. In education governance this kind of power is manifest in the historical dominance of the interests of powerful, Western nations and private sector interests in the governance structures of global financial institutions such as the World Bank (Jones 2007; Mundy et al. 2017; Tikly 2017). Thirdly, structural power, concerns the constitution of social capacities and interests of actors in direct relation to one another. One expression of this form of power is the working of the global capitalist economy in producing unequal social relations of production between capital and labour in Africa as elsewhere. Finally, productive power is the socially diffused production of subjectivity in systems of meaning and signification, including the way that 'development' itself is defined and understood. Here again, as will be suggested below, it is often Western definitions of SD and ESD that predominate in global, regional and national agendas.

Walby describes different kinds of 'regimes of inequality' that can themselves be understood as self-generating/ self-reproducing systems linked to the socially constitutive effects of different forms of power. Regimes of inequality are composed of relations of inequality that cut across institutions (such as education, health and social welfare) and across domains. They include but are not confined to inequalities based on class, gender, race/ethnicity, rurality, disability, age etc. Understanding each regime as being implicated in the development of different domains allows for an appreciation of their full ontological depth. Gender inequality, for example, as we will see cannot be understood without appreciating the gendered nature of labour markets since colonial times, the position of women in relation to the polity and how gender is constructed through different Western and African cultural traditions. Neither can it be understood outside of an appreciation of gendered violence which has both a public side (e.g. sexualised violence in the context of war or as an everyday occurrence in institutions including education) and a private side (i.e. domestic violence). Importantly, regimes of inequality are not reducible to each other. Rather they co-evolve as systems of classification and oppression. They need to be understood in the way that they intersect and mutually constitute each other at the level of individual and group experiences and identities.

Walby's work assists in theorizing the nature and role of global civil society. She conceives of global civil society in terms of global social movements of intellectual and moral energy that transverse traditional institutions and geographical borders. Pan-Africanism, anti-colonialism, neoliberalism, socialism, human rights, feminism, environmentalism, and religious fundamentalisms are examples of civil society waves that have impacted on Africa. They are seen to originate as projects in civil society and then to spread. In the African context, anti-colonial struggles and the development of pan- 
Africanism and of the non-aligned movement have represented distinct civil society waves. Neoliberalism, based on a view of the importance of markets and the need to reduce barriers to the free market and roll back the power of the state was a project that had its origins in the domestic politics of Thatcherism and Reaganism but then developed into a global wave. Environmentalism has also had a presence on the continent although one that has been until recently more muted compared to other development discourses (Obi 2005) ${ }^{15}$. Discourses about the war on terror continue to shape the responses of foreign powers to Africa (Novelli 2010) whilst the growth of Islamic fundamentalism in some parts of civil society in the horn of Africa and in Northern Nigeria etc. have also been influential ${ }^{16}$.

Given the plurality of global civil society waves, Walby points out that although neoliberalism is a powerful global project that has become embedded in some governmental programmes and social formations, it is not the same as globalisation, nor is it fully hegemonic. As De Jaeghere (2017) has recently argued, it is better to think of global education policy, for example, as being shaped by different 'neo/liberal' projects that in the African context as elsewhere have been coupled with other political projects and global civil society waves. This helps to explain why policy relating to SD and ESD takes on a different form in different localities in which neoliberal concerns are coupled with other political projects to produce unique fusions of policy.

Global governance is also usefully conceived in terms of the operation of different 'regimes of global governance'. It has been argued elsewhere that regimes in the issue area of education and development as well as in other areas relating to SD such as environmental governance are fundamentally concerned with maintaining hegemony and legitimising world order (Tikly 2017) ${ }^{17}$. Thus, the current education and development regime has been

15 Obi argues that environmental movements in Africa have tended to operate within a transformative logic in which struggles for power over environmental resources connect broader popular social struggles for empowerment and democracy.

16 The war on terror for example was given impetus from the political response to the $9 / 11$ attacks in the US whilst the spread of Islamic fundamentalism can be seen to be rooted in forms of local resistance to perceived Westernisation and demands for a caliphate in parts of the Arab World as wells in the horn of Africa and Northern Nigeria. Trump's virulent anti-globalisation and re-assertion of protectionist policies coupled with the antiglobalisation rhetoric associated with the leave campaign in the UK may well transform into a new anti-globalisation, global wave.

17 Regimes are defined as "sets of implicit or explicit principles, norms, rules, and decisionmaking procedures around which actors' expectations converge in a given area of international relations" (Krasner 1982, p. 185). It will be suggested that we are currently witnessing a regime change in the area of education from one governed by the norms and principles of the Education for All Movement and the Millenium Development Goals to one governed by the norms and principles of SD and ESD. Regimes have the general characteristics of complex systems in that principles and norms are always emergent and the product of in- 
shaped by networks of actors involved in decision-making within the regime that includes not only multilateral organsiations and national governments but organs of global civil society and, increasingly, education foundations and the private sector (Olmedo 2014, 2017). They have also been shaped through the position of education within a wider regime complex comprising regimes governing, amongst other things, international development assistance, trade and security.

It is against such an ontological understanding that the nature of regional policy itself needs to be understood. In developing understanding, the paper builds on recent work on global education policy within the critical tradition (Mundy et al. 2017; Verger et al. 2018) but will develop insights from this work in relation to the above account of globalisation. At a global scale this involves drawing attention to 'meta-discourses' that shape what can be thought, or in Carney's (Carney 2008) terms, 'policyscapes' that help to frame regional agendas. In this respect as mentioned, a key point of reference for Agenda 2063 and CESA is the adoption of the Sustainable Development Goals (SDGs). Regional policy agendas then serve to mediate and reinterpret global policy in relation to regional interests and priorities which are then mediated and reinterpreted at a national level. Following Ball et al (2012), policy can therefore be understood as a series of socially constructed enactments that span text and practice. This draws attention to the gap between policy intentions on the one hand and what actually goes on at the level of practice on the other hand. It also underlines the importance of the agency of policy makers at different scales in enacting policy and the extent to which policy simultaneously shapes and is shaped by social relations including those based on class, race, ethnicity and gender.

\subsubsection{Social and environmental justice}

In developing a critique of Agenda 2063 and CESA it is important to be clear about the normative position on which a view of transformative SD and ESD is based and which provides a starting point for critiquing the FD and CESA. A starting point comes from the capability approach of Sen and Nussbaum. Described as a 'species of the rights-based approach'18 it sees human development principally in terms of the development of human capabilities (oppor-

teraction and contestation between different interests at play within a regime and in relation to the development of other regimes.

18 As we have argued elsewhere, the capability approach is best seen as a 'species of the rights based approach' but with a stronger emphasis on establishing the ethical basis for rights through processes of informed public dialogue, mobilisation and advocacy rather than through the imposition of top down rights based agendas (Tikly/Barrett 2013). 
tunity freedoms) that enable individuals and groups to achieve valued functionings (beings and doings) that they have reason to value and that will contribute to wellbeing and human flourishing. In the context of the shift to SD as the dominant development paradigm, Sen (2013) has recently argued for an expansion of this idea to take account of the capabilities of future generations and the extent to which this necessitates a concern with environmental protection as inseparable and integral to the realisation of capabilities both now and in the future. This goes beyond the concern with poverty alleviation as the meeting of basic needs as set out, for example in the influential Brundtland report (WCED 1987) to a concern with providing the opportunities and freedoms that enable individuals and groups to convert resources - now and in the future - in a way that supports human wellbeing and conserves the environment.

Sen argues forcefully that issues of freedom and of sustainability are inextricably linked and that sustainability can only be achieved through the realisation of human freedom. Whilst Sen in right about the links between human freedom and sustainability, it is important to add some caveats. Firstly, to note that Sen (2009) himself sees the concept of human capability as both a property of individuals and of groups ${ }^{19}$. This is to understand that regimes of inequality represent sets of historically contingent social relationships based on unequal distribution of material and discursive power between groups and it is at a group level that many of the institutional and other barriers to realising human freedom become apparent and form the basis for group solidarity and action.

It is also important to recognise that Sen's is an anthropocentric view of capability, i.e. a view of capability as applying only to human beings. Nussbaum has begun to articulate a view of other species having capabilities linked to their inherent dignity. She goes on to explain "Each form of life is worthy of respect and it is a problem of justice when a creature does not have the opportunity to unfold its (valuable) power, to flourish in its own way and to lead a life with dignity" (Nussbaum 2006, B7) ${ }^{20}$. Extending this view, Schlosberg (2007) argues that all "individual animals, human and non-human

19 This is significant in the context of this paper because whilst it is important from an evaluative perspective to consider human capability at the level of the individual and in the context of the impact of intersecting regimes of inequality on individual freedom, it is also important to understand how regimes of inequalities impact the capabilities (agency freedoms) of different oppressed groups including those based on class, race/ethnicity, indigeneity, gender, disability etc.

20 Whilst it is important to take account of the rights of other species to flourish, Nussbaum's ideas have been critiqued from within the environmental tradition because by invoking animal dignity she appears to be favouring only sentient beings (Schlosberg 2007). She has also been criticised for focusing on the rights of individual animals rather than on the integrity and flourishing of species as a whole and of ecosystems. 
need not just some others of their own species, but a full environment, including non-sentient life and ecosystem relations, as part of their capability set in order to flourish" and that "it is simply not possible to talk about the flourishing of individual animals without reference to the environment in which this flourishing is to occur" (Schlosberg 2007, p. 142). Schlosberg argues that systems themselves have capabilities and functionings and might be considered agents for the work they do in providing the various capacities for their parts to function - i.e., purifying water, contributing oxygen, providing nutrition, sustaining temperature ${ }^{21}$.

At the heart of Sen's approach towards SD is that determining the capabilities and needs of existing and future generations requires processes of advocacy and informed public dialogue in which the interests of different groups are made transparent and open to public scrutiny. As we have argued previously (Tikly/Barrett 2013), Sen's ideas provide an important evaluative 'space' in this case for considering SD as a process of balancing the capabilities of existing and future generations and indeed of environmental systems. However, on their own, Sen's ideas about justice do not provide a means for considering the wider structural and discursive barriers that prevent some individuals and groups and indeed of other species and of environmental systems from having their interests recognised in public policy. Here it is argued that Fraser's understanding of global justice provides a multidimensional way of conceiving the barriers to social and environmental justice. Fraser defines justice as 'parity of participation'. She explains that:

"According to this radical-democratic interpretation of the principle of equal moral worth, justice requires social arrangements that permit all to participate as peers in social life. Overcoming injustice means dismantling institutionalized obstacles that prevent some people from participating on a par with others as full partners in social interaction." (Fraser 2008, p. 16)

By institutionalised obstacles, Fraser is here referring to economic structures that deny access to resources that people need in order to interact with others as peers; institutionalised hierarchies of cultural value that may deny them the requisite standing; and, exclusion from the community that is entitled to make justice claims on one another and the procedures that structure public processes of contestation ${ }^{22}$. Recognising issues of environmental justice also

21 "In this case, the central issue of ecological justice would be the interruption of the capabilities and functioning of a larger living system - what keeps it from transforming primary goods into capabilities, functioning, and the flourishing of the whole system" (Schlosberg 2007, p. 13). This view of environmental systems themselves having capabilities raises important considerations for educators and these are discussed further below.

22 Important to add here, however, is that an exclusive focus on institutional arrangements can detract from some of the other barriers that may prevent equal participation in social life. For example, besides institutions, discourses can have their own constitutive effects on 
requires extending the view of parity of participation to include a consideration of the rights and capabilities of other species and of environmental systems, point that are developed below.

Fraser draws attention to three dimensions of social justice, each related to one of the institutional barriers identified above. The first, redistribution, relates to access to different kinds of material resources or to services such as education and health. From the point of view of SD, distributive justice would also need to take account of the way that environmental benefits (in the form of access to natural resources) as well as risks (in the form of the effects of global warming, droughts, famines, pollution etc.) are distributed. It will be argued below, for example, that part of the postcolonial condition in Africa as elsewhere is the disproportionate environmental risk that accrues to the most disadvantaged sections of society. In this sense, environmental inequalities cut across and reinforce other inequalities including those based on class, race/ethnicity, gender and disability.

The second of Fraser's dimensions, recognition, means first identifying and then acknowledging the claims of historically marginalised groups in the African context including, for example, women, rural dwellers, victims of HIV/AIDS orphans and vulnerable children, refugees, cultural, linguistic, religious, racial and sexual minorities and indigenous groups. In the context of a transformative SD and ESD, this also means recognising the integrity and the right to flourish of other species and ecosystems, a view that is in keeping with many indigenous knowledge systems in Africa that have posited a more organic, symbiotic and custodial relationship between human beings and the natural world (Maware/Mubaya 2016)23.

Participatory justice includes the rights of individuals and groups to have their voices heard in debates about social justice and injustice and to actively participate in decision-making. Importantly, for Fraser, this is a prerequisite for realising issues of redistribution and recognition. It also ties in with Sen's insistence on public participation and informed public dialogue as the basis

what can and cannot be said, who can speak and with what authority, how our understanding of concepts such as education and development are shaped and how individual and group identities are defined (see paper three). Unterhalter (2007) also draws attention to the more informal, interactive networks and associations at the local, national and global level that criss-cross institutional structures and processes but yet are often important in determining justice claims. Understanding the workings of different kinds of institutional and discursive power at different levels from the macro to the micro is important for the conceptualisation of regimes of inequality.

23 For Schlosberg (2007), it is this aspect of recognitional justice that sets his view of environmental justice apart for that of Nussbaum's in that the focus is on the flourishing of whole ecosystems rather than on the rights of individual animals. This also leads to a nonromanticised view of environmental flourishing in that, for example, being food for other living beings might form part of essence of functioning for some living things. 
for adjudication between justice claims. In relation to participatory justice Fraser identifies two forms of misrepresentation. The first form is related to issues of what Fraser calls 'ordinary-political representation'. It is concerned with the nature of political rules and processes within nation states that deny some citizens the chance to participate fully in decision-making. The second form of misrepresentation is related to globalisation and has increasing significance for education in low income countries because of the influence over national policy of global and regional agendas and frameworks. Fraser describes this as 're-framing'. Here the injustice arises when the community's boundaries are drawn in such a way as to wrongly exclude some people from the chance to participate at all in its authorised contests over justice.

Schlosberg (2007) has considered how Fraser's and indeed Sen's views about the importance of participation might be extended to incorporate environmental and ecological concerns. Noting the obvious point that other species or natural systems do not have the same reasoning or communicative capacities to participate in processes of democratic deliberation, he nonetheless argues that the capabilities and flourishing of other species and natural systems can and ought to be the subject of public deliberation ${ }^{24}$. Such a view has important implications for education systems in creating a space for this understanding of the capabilities and needs of other species and of environmental systems in order to flourish. Nussbaum (Hoogvelt 1997, 2006), for example, talks about the importance of imagination and story-telling in accessing the capabilities of other animals. All of the disciplines spanning the natural and social sciences, arts and humanities have a positive role to play in this respect.

Drawing together the above discussion, it is useful to summarise what is meant by social and environmental justice in the context of this article ${ }^{25}$. At the most general level, and extending Fraser's earlier definition, social and environmental justice can be understood as putting in place social arrangements that permit existing and future generations to participate as peers in social life and that recognises the integrity of other species and of natural

24 He argues that in "applying a capabilities approach to nature, we do not need to have a particular animal or ecosystem express a desire for a particular functioning; rather, we need to recognise a different type of agency - a potential, a process, or form of life illustrated by its history, ecology, integrity, and non-reason-based forms of communication" (Schlosberg 2007, p. 152).

25 Scholsberg (2007), following Sen, makes the point that definitions of concepts such as justice or capability are necessarily contextually bound and that it is in fact important to embrace the possibility of a plurality of definitions and understanding as to which aspects of social and environmental justice and which capabilities are particularly relevant across different contexts. Developing a pluralistic and context sensitive view of the meaning of social and environmental justice is important, for example, in the context of bringing together different kinds of social and environmental movements in struggles against injustice. 
systems. Overcoming injustice means dismantling institutionalized obstacles that prevent some people from participating on a par with others as full partners in social interaction and well as barriers that prevent the wellbeing and flourishing of other species and of natural systems. Some of the implications of this view of social and environmental justice for a transformative ESD are set out below.

\subsection{Interpreting regional policy in relation to the postcolonial condition}

In this section an attempt will be made to read Agenda 2063 Framework Document (FD) and CESA against an analysis of the postcolonial condition and an understanding of social and environmental justice set out in previous sections. In keeping with the discussion of globalisation above, the section will explore education's role in relation to the seven inter-related domains of the economy, the polity, civil society and of violence as well as the social, cultural and environmental domains. The key argument advanced is that whilst the FD and CESA provide an overview of the development opportunities and challenges facing the continent, they provide only partial explanations of the underlying causes of Africa's malaise. Rather, the roots of unsustainable development captured in the various challenges set out in Agenda 2063 and CESA can in fact be traced back to the colonial encounter and that education has been complicit in these. It will also be argued that whilst the FD and CESA go some way towards setting out transformative, Africa-led agenda for SD and ESD, they are limited by the predominance of narrow instrumentalist concerns linked to global and indigenous elite interests.

\subsubsection{The economic domain}

The FD points out that African economies have been among the fastest growing in the world in recent decades but with variation within countries and regions. Growth according to the FD can be attributed to an expansion of foreign investment in extractive industries such as mining and oil and to a lesser extent by the growth in the agricultural ${ }^{26}$ and informal sectors, in in-

The report goes on to state that in a small number of instances, such as Rwanda and Ethiopia, increased levels of growth have been attributed to increases in agricultural production. 
formation technologies and in remittances from the diaspora ${ }^{27}$. Amongst the challenges, the FD notes a decline in the export of manufactured goods and a very small proportion of high technology manufactured goods and a lack of productivity in the agricultural sector. This is attributed to a variety of factors including poor infrastructure (roads, transport, electricity etc.) the relatively small size of African enterprises, a shortage of inter-firm linkages and importantly for our purposes, skills.

Whilst at a general level the FD provides a reasonable overview of opportunities and challenges in the economic domain, it does not go far enough in outlining the underlying causes of these or indeed the implications for society and for the environment. For example, it is important to recognise that the current path dependency of African economies on the extraction of raw materials is deeply entrenched and linked to economic interests that can be traced back to colonial times. European colonialism from the sixteenth century onwards was based largely on the extraction of raw materials including agricultural products and minerals from the global South which were then converted into commodities in the global North and sold back to the global South often at a profit (see for example Rodney 1973; Hoogvelt 1997; Akyeampong et al. 2014). A key motive for European colonisation of Africa was economic and political competition between the European powers which became known as the 'scramble for Africa' ${ }^{28}$. The colonial economy was also based on the extraction of an estimated 12 to 15 million Africans in the form of the transatlantic slave trade. Whilst the slave trade benefitted development in the America's it led to a huge loss of people and skills and played a significant

27 The report cites statistics for example that show that during the 2002-2008 period, Africa's economic growth rate averaged 5.6 per cent per annum. There has also been an increase in per capita income which more than doubled from US\$958 (2004) to US\$1878 (2012) although, economic growth has slowed on the continent subsequent to the publication of the report because of a fall in prices of raw materials on international markets and a slowdown in growth in emerging markets which imports raw materials from Africa (WBG 2017).

In what has been termed the 'Scramble for Africa', fourteen European nations met - without African representation - at the West Berlin Africa Conference of 1884-1885, "wishing to regulate in a spirit of good mutual understanding the conditions most favourable to the development of commerce and of civilization in certain regions of Africa...; desirous on the other hand to prevent misunderstandings and contentions to which the taking of new possessions on the coast of Africa may in the future give rise, and at the same time preoccupied with the means of increasing the moral and material well-being of the indigenous populations" (General Act of the Conference of Berlin Concerning the Congo 1909, p. 7). The subsequent partition of the 'magnificent cake' - Africa - has been described by Anghie (2004, p. 91 in Craven 2015, p. 33) as transforming Africa "into a conceptual terra nullius" through an ideology of colonial rule or "doctrine of trusteeship" (Cowen/Shenton 1996 in Okolie 2003, p. 237), under which 'developed' societies subordinated native claims to sovereignty and determined how 'primitive' societies would develop. 
role in holding back development on the African continent (Akyeampong et al. 2014; Eltis/Richardson 2008).

Even after independence, as Nkrumah (1966) pointed out in his seminal account of neo-colonialism, economic relationships between Africa and the countries of the former metropole continued to be based on the extraction of raw materials to support industrialisation in the global North. An important influence for governments such as those of Ghana and Tanzania that wished to break free from these global relationships was the development of dependency theory by Frank (1970) and the dependency school. This provided a compelling argument about the negative consequences of economic dependency of low income countries to countries of the former colonial metropole. It provided an impetus - alluded to in the FD - for newly independent countries adopting import substitution industrialization policies as a way of breaking dependency ${ }^{29}$ and is significant because it demonstrates the possibilities and challenges faced by African countries in seeking to break this dependency under globalisation.

The emergence of neo-liberalism as a global wave from the late 1970s had a major re-territorialising effect on Africa's relations with the global economy. The policies, collectively known as Stabilisation and Structural Adjustment Polices (SAPs) (Robertson et al. 2007) ${ }^{30}$ included a range of measures related to fiscal austerity, deregulating the economy and opening it up to international competition, rolling back the ambit of the state in financing public services and encouraging privatisation. This new policy orthodoxy became known as the 'Washington Consensus'. The policy measures were linked, through conditionality clauses with low-income debtor nations, to loan agreements issued by the IMF in agreement with the World Bank. In Barnett and Duvall's (2005) terms they are mechanisms of conditional power. Conditionality clauses thus became the key mechanism through which neo-liberal economic policies became globalised and spread throughout lowincome countries (Hoogvelt 1997) and by which Africa could service global

The theory was critiqued for offering too pessimistic an analysis of the prospects of low income countries in the face of dependency and the failure to address macroeconomic policies within low income countries themselves. Nonetheless traces of the underlying sentiment informing dependency theory, i.e. the fundamental need for African-led development is evident in the FD. It provides a source of tension and contradiction with the reality of the new primitive accumulation on the continent led by FDI (below) and the continued dependency of many Africa countries on large amounts of foreign assistance including in areas such as education which has the effect of increasing dependency and fragmenting the possibilities for autonomous development through the need to respond to sometimes contradictory donor agendas (e.g. between the Chinese and Western powers).

The Mexican debt crisis led to a dramatic shift in the policies of the World Bank and the IMF during the late 1970s and early 1980s. These institutions developed a set of neo-liberal policies that served to ensure that debtor countries were able to service their debts. 
financial flows through its position as a debtor continent in an extractive global system of debt peonage.

The impact of SAPs were devastating in terms of human development and led to the so-called lost decades of development (below). The call for 'adjustment with a human face' (Robertson et al. 2007) represented a challenge to the international financial institutions whose policies, despite never calling explicitly for budget cuts to health and education, had nonetheless pushed many low-income countries (as well as those in the 'north') into prioritising debt repayments over social spending. Added to this, there was also criticism over the failure of SAPs to either reduce poverty and inequality or to achieve sustained economic growth in low-income countries.

The development of the discourse of 'inclusive growth' that underpins the FD needs to be seen in this context. Developed by economists in the World Bank and OECD and propagated by other multilateral and regional organisations including the African and Asian Development Banks, inclusive growth develops earlier development discourses such as modernisation theory (Rostow 1960) and neoliberalism which see growth as a linear process that is market-driven. Unlike more pure forms of neoliberalism such as those that informed SAPs, it envisages a limited role for governments in providing a human safety net to ensure the poorest sections of society benefit from economic growth in absolute terms and facilitates the adoption of scientific and technological solutions to offset environmental degradation and to replace forms of natural capital ${ }^{31}$. The idea of inclusive growth is central to Agenda 2063. It is reflected in plans to modernise the manufacturing and agricultural sectors for example and for the blue/water economy in a way that promotes shared growth, decent jobs and economic opportunities for all and contributes to food security.

However, there is sharp contrast between the rhetoric of inclusive growth and the development of extractive practices under neoliberal inspired reform that are themselves deeply rooted in global capitalism. As Harvey (2011) has argued for example, the development of neo-liberalism since the 1970s was a consequence of capitalist over-accumulation in the global North and the need to restore the profitability of capital. The major political transformations in the former Soviet Union and in China also served to release hitherto unavailable assets into the global economy as has unprecedented growth in South East Asia in the wake of the 2007 shock. These developments are associated with changes in the locus of power and influence within the global economy. Over-accumulation of capital has contributed to a 'revitalisation of primitive accumulation' (Harvey 2003) (that is accumulation that is based on the ex-

31 This perspective has its origins in debates about the limits to growth in the 1970s encapsulated for instance in the Club of Rome, that focused on the dangers of untrammelled growth for the environment. 
traction of primary commodities and on cheap labour) as a way of increasing the profitability of capital.

It is this turn to primitive accumulation together with concerns about energy and food security in China, the US and elsewhere that lies behind the 'new scramble for Africa' (Ayers 2013; Mohan 2013). This has involved investing Western based capital and to a lesser extent capital linked to China and the other rising powers in extractive mining industries and agriculture. Thus whilst as is suggested in the FD, the new scramble for Africa has coincided with a period of economic growth especially following the 2007 financial crisis, it has not led to sizeable gains for ordinary Africans because as Ferguson (2006) has pointed out, the vast majority of this growth has been through foreign investment and has occurred in enclaves and have remained shut off from local communities who have not benefited directly. It has also happened in the form of land grabs in which vast areas of land have been effectively privatised and sold off to foreign interests (see also Ayers 2013) and which has had dire consequences for human and environmental development as noted in the FD. China has also exported large numbers of labourers to work on agricultural and infrastructure projects in Africa such that in many cases, new projects have often not led to increased opportunities for the employment of Africans themselves (Mohan 2013).

Missing from the analysis contained in the FD is a recognition of the indigenous as well as foreign interests that have been served through the predominance of different kinds of extractive practices. Thus, whilst under colonialism it was the mercantile classes within the colonial powers that benefited most from the extraction of raw materials from Africa, in the postindependence period indigenous elites have also benefitted through their access to state power, more limited access to capital and from their insulation from the worst effects of structural adjustment. Education policy needs to be seen in this context of overlapping but conflicting economic interests between African based and foreign capital and in relation to different class interests within Africa itself.

Colonial education policy on the African continent was driven by a complex mixture of differing colonial interests and motives, as historians have made clear (see for example Mangan 1988; Altbach/Kelly 1978) ${ }^{32}$. It is also important to take account of differences between the colonial powers in the way that colonial education was conceived in relation to the broader 'civilismissionaries dating back to the sixteenth century. In South Africa missionary education was introduced following the arrival of the Dutch in 1652. In many parts of the continent, however, missionary education preceded formal colonial rule. Evangelical missions, predominantly from Protestant churches in Europe, taught literacy and manual skills, while the Anglican and Catholic missions (the latter predominating in French and Portuguese colonies) generally had a more academic focus (Cowan et al. 1965, p. 4). 
ing mission' (White 1996). A key rationale, for the introduction of forms of mass education under colonialism, however, was economic. In all cases, access to education was not universal and was for most learners limited to a few years of basic education with very limited access indeed to secondary education. Access was particularly limited for girls although greater emphasis was placed on the education of girls within the British system. Here, however, as historians have argued, this was linked to efforts to socialise girls into the roles expected of them in the home and in the labour market (White 1996; Gaitskell 1988).

There were differences in the form and content of education introduced by the different colonial powers. In the case of both the French and the English, however, there was an emphasis on a primary curriculum more suited to the needs of the rural areas. In the English case this took the form of 'adapted education' ${ }^{\prime 3}$. In both cases too there was limited access to secondary education as a means to develop a small cadre of Africans who could staff the colonial administrations and provide a point of contact with ordinary Africans.

Colonial education can be said to have had both a positive and a negative correspondence with the economic domain under colonialism. For example, whilst colonial education policy was geared towards supporting the rural economy, the reality was a loss of rural livelihoods for Africans in the context of mass urbanisation. In the run-up to independence, there was also increasing resentment on the part of Africans towards an agriculturally and vocationally oriented education and growing demands for an expansion of secondary education which was associated with an elite position in the colonial administration. The elitist nature of education has persisted in the postcolonial period. Indeed, it has been a defining characteristic of the path dependency adopted by African education systems that until relatively recently they have been characterised by low levels of access for the poorest, outmoded, content-driven curricula and assessment systems that are both cognitively and linguistically demanding and that have played a strong filtering role in limiting access to higher levels of education.

Two discourses were key in defining education policy across the postcolonial world in the immediate post-independence period. Besides moderninsation theory (above) which identified education as a key institution for developing the skills required for a modern economy. The other, was human capital theory originally developed by Theodore Schultz (1961). The

33 I.e. a curriculum "adapted to the mentality, aptitudes, occupations and traditions of the various peoples" and particularly focused on developing agricultural and other skills suited to life in the rural areas (White, XXX: 19). The view of adapted education was based on notions of cultural relativism in contrast to the cultural universalism of the French. In this view, African cultures could at times be valorised. 
latter has proved durable although it has changed in form and emphasis over the years (Robertson et al. 2007). During the 1960s and 70s it was associated with modernisation theory, in the 1980s with the development of rates of return analysis (below) and from the 1990s with the role of education in poverty reduction and subsequently in promoting inclusive growth and the knowledge economy.

SAPs had a negative effect on both enrolments and the rate of enrolments as was widely reported at the time (Samoff 1994). It is the above context that the MDGs were introduced. Informed by rates of return analysis ${ }^{34}$, the emphasis was on expanding access but this meant in practice access to the lowest tiers of a highly fragmented system often with a negative consequence for the quality of education (Tikly/Barrett 2013). The MDGs also had the effect of siphoning off the limited resource that had previously gone into financing higher levels of education. For elites this made little difference as they could continue to access high quality private provision and to attend overseas universities. For the majority the effects were to further restrict access to these levels and to further undermine the quality of provision through decades of systematic underfunding. Ironically given the emphasis in CESA, the diversion of funding from higher education further undermined the capability of higher education systems to furnish the higher order technical and scientific skills required for indigenous systems of innovation to flourish.

It is against this backdrop and in relation to the view of social and environmental justice given above that the strategic priorities in CESA need to be interpreted. On the positive side, CESA argues for an expansion of access at all levels including historically marginalized groups such as rural dwellers and girls/women. It also calls for an expansion of investment in infrastructure and especially in teachers which is critical for improving the quality of education (Tikly/Barrett 2013). Here in Fraser's terms there is a strong redistributive element. There is also an emphasis on a more holistic approach to TVET that recognizes the potential role of TVET in supporting the development of rural economies and the informal sector. Once gain this can be seen as recognising claims for sustainable livelihoods in the rural areas. These concerns can be seen to correspond to a rights based discourse on education that has developed in the context of the global Education for All movement (Tikly 2017).

Here, George Psacharopoulos' (1983) work on individual and social rates of return to different levels of education was significant. In relation to rates of return analysis, primary education is seen as a principal means to eradicate poverty because of its relatively high social rates of return to gross domestic product (GDP) and growth. In this way, human capital theory became linked to structural adjustment lending and the increased use of development targets by multilateral agencies. 
The rights-based discourse stands in contrast, however to the dominant economistic rhetoric of CESA. At the very heart of CESA is the view that education should contribute to the development of human capital to develop a knowledge economy. This leads to the emphasis on the instrumental aspects of schooling and especially science and mathematics education, the development of higher order technical and vocational skills and the role of higher education in supporting innovation and enterprise.

Ideas about the knowledge economy are not new to the continent. Resting on the four pillars of education and training, the development of an information infrastructure, providing an economic and institutional regime to support knowledge flows and supporting innovation systems, the idea of the knowledge economy has been advocated by the World Bank since the 1990s (Robertson et al. 2007). Policies linked to the idea of the knowledge economy find prominent expression in the education and training policies of several African countries including, for instance Rwanda and Tanzania (Tikly et al. 2003). As has been argued elsewhere, whilst the idea of a knowledge economy is intuitively appealing to policy makers, it can often operate rhetorically as a panacea for solving economic crisis that has its roots in Africa's position in relation to the global economy and unequal social relations of production.

Here some of the critiques of human capital theory (HCT) are also pertinent. To begin with, it posits a narrow view of the role of schooling linked to growth. For Sen, growth, whilst important, is a means to achieving wellbeing and realising human freedom rather than an end in itself (Sen 1999). In this case, the role of education is perceived more broadly as developing capabilities (opportunity freedoms) that lead to valued functionings (beings and doings). These might include but also go beyond a narrow focus on instrumentally useful knowledge. Indeed, as has been recently argued with respect to STEM (Science, Technology, Engineering and Mathematics) education in Africa, developing creativity, problem-solving and other kinds of skills necessary for innovation and enterprise involves an emphasis on the creative arts and humanities as well as science and mathematics (Tikly et al. 2018). Like modernisation theory, HCT is also premised on an idealistic view of a direct correspondence between investing in human capital and economic growth when as we have seen, the relationship is more complex. Part of this complexity is that growth itself is never a linear process and is subject to periodic crises. Such a view urges caution in naively assuming education can act as a panacea for economic growth in the way that HCT implicitly does but rather sees the importance of understanding the complex relationship between education and the economy and the need for a more joined up, strategic approach to integrating education policy and skills formation into wider developmental agendas as in fact happened in many of the South East Asian economies (Tikly 2003). 


\subsubsection{The political domain}

The FD points to increases in the number of democracies on the continent and in multi-party elections. It also points out that most elections are now violence-free. The report highlights some improvements in economic governance $^{35}$ including success in tackling corruption ${ }^{36}$ which it considers has a bearing on the sustainability of economic performance of African countries. However, it notes that policy making and service delivery remain compromised due to poor public institutions and administration at central, municipal and local levels, leaving many citizens poorly served by their governments (AUC 2015, p. 62). The report argues that the quality of democracy remains a challenge with huge variability in the extent to which democratic norms are internalised and implemented ${ }^{37}$. The FD posits the notion of the 'developmental state' as a possible way forward for improving governance. Significantly, the FD addresses Africa's position in relation to processes of global governance. This is important because as an exporter of primary goods, the continent is exposed to externally imposed changes in the prices of commodities and is subject to a multitude of externally imposed agendas and initiatives.

Again, it is useful to consider the analysis provided by the FD in historical perspective which allows for an understanding of the deep-rooted nature of the issues involved. Global discourses relating to politics and good governance often assume a Westphalian model of the state. This fails to take account of the relative newness of African states and their difficult birth as part of the 'scramble for Africa' (above). At a political level, European colonialism also resulted in the introduction of highly centralised and authoritarian state structures which were intended to serve the interests of the colonisers and did not acknowledge some of the complexities of incorporating into one territory diverse ethnic groups and in some instances the challenges involved in governing vast, sparsely populated swathes of land given limited governmental capacities (Herbst 2000).

Indigenous elites were assimilated into these existing structures. As Mamdami (1996) has cogently argued, this led to an increasing bifurcation

The report notes improvement in domestic resource mobilisation and public administration, modest progress in tackling corruption, significant improvements in the business climate and progress in stemming illicit capital outflows.

36 Although the FD also notes that according to transparency international, four out of five African countries are below the world average (AUC 2015, p. 64).

37 It points to detention without trial, arbitrary arrests, torture, forced disappearances and extra-judicial killings which it claims are still unfortunately widespread whilst access to justice and independence of the judicial system is a major concern. The report highlights pervasive weaknesses of institutions, especially in the field of human rights at national, regional and continental levels. 
between urban elites subject to the power of the colonial state and rural dwellers who were still subject to traditional forms of authority - a bifurcation that is still evident in the postcolonial era between 'citizens' of the modern state and 'subjects' of more traditional forms of authority. The difficulties in instituting democratic rule and the use of the state to advance the interests of some ethnic groups at the expense of others can, according to Mamdami, be traced back to this dynamic.

The advent of the development era can be seen as a very conscious effort at de-territorialisation and re-territorialisation of the polity at the global, regional and national scales. Key moments in the birth of the development era were the formation of the Bretton Woods financial institutions in 1944 including the World Bank and the IMF and the General Agreement on Tariffs and Trade which were aimed predominantly at post-World War Two reconstruction in Europe. Another key moment was the establishment of the UN under article 55 of the UN charter in 1945 which enjoyed the support of the US and its Western allies ${ }^{38}$. However, it was President Truman's inaugural address in 1949 in which he referred to 'underdeveloped areas' and identified poverty as a threat to prosperity and peace is often cited as the point at which the 'development era' officially commenced ${ }^{39}$.

The advent of the cold war in the post WWII period also provided a political rationale for the West to embark on a development mission as a means of keeping the newly labelled 'developing world' out of the orbit of the Soviet Union and its allies. In the context of the cold war, state building became implicated in global politics with both Western and Eastern powers propping up sometimes corrupt and authoritarian regimes in support of their own global ambitions and economic interests. This, according to Bayart (2009) led to the formation of two 'ideal types' of postcolonial state based on projects of

The founding charter set out the aims of the UN as creating worldwide peace, well-being and stability. Envisioning 'higher standards of living, full employment, and conditions of economic and social progress and development; solutions of international economic, social, health and related problems; and universal respect for and observance of human rights and fundamental freedoms for all without distinction as to race, sex, language or religion' (UN 1945), the Charter goals "created moral pressure for institutional and policy change" (Koehler 2015, p. 734) as did the adoption of Universal declaration of Human Rights in 1948.

39 President Truman set out a vision of the future for the world's low-income countries and coined the term 'development' to refer to processes of economic and social progress in colonial and post-colonial states: "We must embark on a bold new program for making the benefits of our scientific advances and industrial progress available for the improvement and growth of the underdeveloped areas....I believe that we should make available to peace loving peoples the benefits of our store of technical knowledge in order to help them realise their aspirations for a better life.....The old imperialism - exploitation for foreign profit has no place in our plans. What we envisage is a program of development based on the concepts of democratic fair dealing." (Truman 1949: Point Four). 
'conservative modernisation' on the one hand and 'social revolution' on the other hand ${ }^{40}$. Both represented different underlying views of modernity.

At a regional scale the idea of pan-Africanism also provided impetus for the formation of the Organisation of African Unity (OAU) in 1963 as a counter-point to the consolidation of the US-led historical bloc ${ }^{41}$. It later transformed into the African Union. Similarly, the creation of the non-aligned movement as a consequence of the Havana Declaration of 1979 was an effort to create a forum to represent the views of members on the international stage $^{42}$. More recently, the discourse of the African Renaissance has built on the pan-African vision ${ }^{43}$. The concept has informed the New Partnership for Africa's Development (NEPAD) which was adopted by African heads of state in October 2001. For our purposes, what is significant is that the development of the AU, NEPAD and now Agenda 2063 organised around a concept of an Africa Renaissance can be seen as an example of the developmen-

40 Each of these projects can be seen to have articulated with both 'capitalist' and 'socialist' growth paths and with single and multi-party systems. The former emerged where already established elites had maintained their power (such as in Senegal, Cameroon, Botswana and Burundi) and the latter involved the rise of at least a section of the subordinate groups (e.g. Angola, Mozambique, Kenya and Tanzania). Both projects had at their centre concepts of 'development' and of 'nation building' although they have differed in their specific character (see also Mkandawire 1996). Where hegemony has been maintained in both cases it has involved the 'reciprocal assimilation of elites', i.e. a process of ameliorating emerging or existing elites through granting limited access to status and wealth.

41 Constituting "a crucial moment in the process of norm socialization on the continent" (Williams 2007, p. 263), the Organisation of African Unity (OAU) was established in 1963 at Addis Ababa, with the intention of promoting inter-African cooperation and eradicating all forms of colonialism. During negotiations, two major competing groups of African states became visible - the Casablanca bloc and the Monrovia bloc -, each of which had differing visions of pan-African unity, the latter based on the idea of a supranational panAfrican government similar to a United States of Africa and, the latter committed to a looser federation of independent states. The formation of the OAU which later transformed into the African Union can be seen as a compromise between these positions.

42 The aims of the non-aligned movement was to ensure "the national independence, sovereignty, territorial integrity and security of non-aligned countries" in their "struggle against imperialism, colonialism, neo-colonialism, racism, and all forms of foreign aggression, occupation, domination, interference or hegemony as well as against great power and bloc politics," by Fidel Castro in the Havana Declaration of 1979. Significantly, all the countries of Africa despite being aligned with either the Western or Soviet blocs also became members of the non-aligned movement which has more recently taken on more of a co-ordinating role in representing the voices of low income countries around the world.

43 Usage of the term can be dated back to Nelson Mandela's (1994) speech to the OAU summit in Tunis in which he spoke of the vision of an African Renaissance following on the liberation of South Africa. It is Thabo Mbeki, however, who is most credited with articulating and developing the concept in the form of a call to action for Africans at the turn of the new millennium. Subsequently, the term has become a point of reference for politicians in Africa, has spawned a number of conferences and led to the establishment of the African Renaissance Institute in Tshwana (formerly Pretoria). 
tal regionalism (Robertson et al. 2007). Thus, whereas earlier forms of regionalism on the continent are associated with the free trade of goods and people, developmental regionalism seeks to project a regional identity and to develop political projects at a regional level in order to advance development.

Western inspired neo-liberal reforms have been deeply implicated in processes of re-territorialising political space. A major implication of neo-liberal inspired reform has been a 'hollowing out' (Ferguson 2006) of the state in Africa. That is to say that whereas states in the post-independence era were seen as the main vehicles for development and were often characterised by assertive Africa-led leadership, this has been increasingly challenged under neo-liberalism. Rather, cut backs in government expenditure and the streamlining of state bureaucracies have had the perverse effect of increasing dependency as the capacity to govern has decreased further. This process of hollowing out has also exacerbated rather than eased the problems of socalled 'failed states' in which warlords and bandits often assumed the role of governing hard to govern areas (Herbst 2000).

Within this historical context of the 1990s that the 'good governance' agenda also emerged, as both an explanation of, and solution to, the deficiencies of the Washington Consensus development model. Broadly, the concept 'good governance' embraces the idea of an efficient public service; respect for human rights; an independent judiciary and legal framework; economic liberalism; protection of private property; political pluralism; participation, administrative accountability; transparency and respect for the law (Robertson et al. 2007).

Like neo-liberal prescriptions for the economy, the good governance agenda continues to play a major role in shaping how Western governments and multilateral organisations 'do business' with Africa and it is therefore not surprising given the enormous conditional and institutional power held by these organisations that the good governance agenda features so prominently in the FD and CESA as part of the wider inclusive growth agenda. The good governance agenda is evident in the FD, for example in the emphasis on strengthening democratic rights, eliminating corruption and sound economic management. In relation to promoting democratic rights there are clear overlaps between the good governance agenda and inclusive growth and human rights discourses. However, there are also tensions.

Missing from the analysis is a consideration of divergent political interests. Furthermore, as was the case during the cold war, extractive industries have often grown just as quickly in territories that exhibit 'good governance' as they have in so-called failed states which has led to foreign governments being prepared to turn a blind eye to human rights abuses (Ayers 2013). It is against this background that the discussion of the potential for a developmental state in the FD needs to be interpreted. With one eye firmly on East Asian development models, the FD makes the case for a stronger role for the state 
in relation to development. As in South East Asia, the developmental state has the advantage of providing a conducive climate for good governance to support capital accumulation under FDI whilst protecting entrenched interests within the state all under the rubric of 'development'.

As is well documented, Chinese economic investment in Africa has been accompanied by new forms of development assistance based on the provision of infrastructure in exchange for favourable access to natural resources and land (Mohan 2013). In education it has also involved the exercise of soft power through the role of Confucius institutes on the continent and making available large numbers of scholarships in China for African students (King, 2013). A characteristic of Chinese development assistance is that it has been based on strict adherence to the principles of non-interference, a key touchstone of the so-called 'Beijing consensus' (Ayers 2013). This has led some Western powers and institutions such as the World Bank to raise concerns about how Chinese development assistance is 'undermining' Western reform efforts in African economies ${ }^{44}$. The implication for many African countries is the need to deal with an increasingly fragmented development assistance architecture that comprises not only different kinds of models of 'partnership' but also engaging with different underlying conceptions of modernity and development, in this case Chinese and Western.

It is in this context that Africa's marginal position and relative weakness in relation to processes of global governance becomes apparent. As the FD points out, "global governance matters a great deal for Africa as decisions made in global institutions and forums have a direct impact on the wellbeing of Africans and their continent. Yet Africa has to date been a marginal player in the governance of global institutions. This is particularly so with respect to international peace and security, economics, environment, and trade issues, and in other areas" (AUC 2015, p. 74-75). The report particularly highlights Africa's lack of representation in the United Nations Security Council, pointing out that although half of the resolutions passed in 2011 related to Africa but Africa has not among the permanent members and African members have no veto power. Similarly, Africa is not represented on the Bretton Woods global financial institutions despite the inordinate amount of influence the World Bank and IMF have had over Africa's affairs. Finally, the report points out that whereas the EU represents 27 European countries in the World Trade negotiation, the AU is not a member of the WTO which weaken the

As commentators such as Ayers and Mohan point out, however, such concerns smack of hypocrisy in that Chinese investments in Africa fall far short of Western interests and that raising such concerns elides the role of the West since colonial times in supporting undemocratic practices on the continent. In this regard, as Ferguson notes, a perverse effect of neo-liberal policies has been that economic growth has often occurred in enclaves within highly dysfunctional states. 
collective voice of Africa over global trade. In Fraser's terms, the upshot is that ordinary African citizens suffer both from a break-down in processes of ordinary-political representation and again through the imposition of top down global and regional agendas in which they or indeed their leaders have limited say.

Once again, education policy can be seen as being complicit at a number of levels in the development of contemporary forms of the state but has been contradictory in its effects. Highly centralized, bureaucratic and undemocratic systems of education were introduced under colonial rule although there were differences in the way education was governed. Some of these differences were linked in Foucault's terms to differences in colonial governmentality (i.e. in the art and practice of colonial government) between the differing colonising powers with a tendency towards greater centralization in the French compared with the English systems and with implications for relationships between the colonial state and religious bodies in civil society (below).

Nonetheless, at a general level, education under colonial education acted as a socialisation mechanism with the aim of rendering the colonised economically useful and politically docile (Rodney 1973). In this respect, the expansion of secondary and tertiary education opportunities whilst highly functional for the colonial administration was also contradictory for the wider colonial project because it had the unintended consequence of developing a cadre of Africans some of whom would go on to lead national struggles for independence. For those with access, education has continued to play a socialising role in the post-independence era. Education systems have remained highly centralised until relatively recently. Schools are also highly authoritarian places in Africa as elsewhere. This is demonstrated in the prevalence of formalistic, teacher centred approaches to delivering the curriculum, the often conservative nature of the curriculum itself, the widespread use of corporal punishment and the lack of opportunity for student and teacher voice at an organizational level (Davies 2008).

In relation to the vision of social and environmental justice offered earlier, there is an important role for education in promoting democratic citizenship. In this respect CESA does contain objectives that are consistent with the idea of social and environmental justice. Expanding access to education at all levels and promoting adult literacy are ways of improving understanding and awareness of democratic processes and more educated populaces are better equipped to hold their leaders to account (UNESCO 2017). CESA also makes a call for an expansion of citizenship education (although there is little indication on what the content of such an education might entail). Whilst recognising the highly political role of education under colonialism the FD and of CESA are muter about the socialising role of education in the postindependence period and how citizenship education might transform this. 
Rather, the emphasis is on the managerialist aspects of the good governance agenda. Thus, for example, improving accountability of teachers is emphasised as a means to improve their performance and hence learning outcomes. This rather narrow view of accountability does not take account of the need for greater teacher voice and autonomy or the need to hold politicians and policy makers or indeed donors accountable for failed education policies.

\subsubsection{The domain of civil society}

By civil society is meant organisations and individuals that represent distinct economic, political and religious/cultural interests that lie outside of the gambit of the state. In the African context these include religious organisations, the private sector and NGOs for example. Civil society has a contradictory relationship with the state, sometimes being included in processes of governance and sometimes in direct antagonism with the aims of government. The extent of involvement of institutions in civil society including faith based organsiations and the private sector has also been significant in shaping the form of the state. The FD is relatively quiet on the role of civil society in governance. It draws attention to the fact that "civil society participation and contributions to democracy is frequently handicapped by their capacity and resources" (AUC 2015, p. 62) but it does not delve more deeply into the issues involved. This is despite the fact that since colonial times, civil society organisations at national and global scales have played a prominent role in education as in other spheres.

For example, the churches played a significant role in education, health and other areas under colonial rule although their role differed depending on the colonising power. Within the more centralized French system, for example, mission schools for the most part were absorbed within the system of government schools. More decentralized education systems introduced under the English on the other hand, experienced less direct control from the British Colonial Office and allowed for greater autonomy for missionary bodies in the running of schools, mirroring the more voluntarist nature of the English education system (Whitehead 2003). These differences were also reflected in attitudes to pre-colonial Islamic schools in West and Eastern Africa which were well established dating back to the tenth century and earlier waves of globalisation from the Arab world. Although treated with suspicion by both the British and the French, they were more likely to be tolerated within the British colonial system than the more secular French system (Launey 2016).

For religious bodies, having influence over the education system was considered key for achieving their proselytising aims. Different religious bodies represented different interests within the state and civil society. They played a powerful role in spreading Christian and Islamic beliefs, often operating in 
antagonism with indigenous belief systems. Islamic and Christian-run schools also operated quite different forms of pedagogy and at a cultural level projected alternative views of modernity. The churches, often vied with each other for control over the education system. They sometimes took differing positions either in support of the colonial administration or against it in the context of struggles for national independence and in their relationship to postcolonial governments. In the period following independence, churches were often allowed to maintain their role as a provider of education and comprise a significant proportion of state-aided and independent secondary and primary schools in many African countries.

During the struggles for national liberation from colonial rule on the continent, liberation movements emerged from within civil society as a direct political and military challenge to White supremacy. In some instances, they had an explicit educational agenda. The African National Congress and Black Consciousness movements in South Africa along with the South West African People's Organisation (SWAPO), for instance had strong educational agendas (Tikly 1994). The ANC, for instance, organised its own school on land donated by the Tanzanian government in the early 1980s based on a vision of an alternative to Bantu education whilst Steve Biko as a figurehead of the Black Consciousness movement wrote extensively about education as a means to liberate the black mind from the effects of apartheid and racism (Biko 1978). The Tanzania African National Union (later Chama Cha Mapinduzi) in Tanzania launched an ambitious adult literacy programme linked to a vision of Ujaama (African socialism) that was highly successful in eradicating illiteracy in the early years following independence. The relationship between literacy and rural development is noted in CESA ${ }^{45}$. For the most part, however, once national liberation was achieved, the education systems often reverted back to the path dependency of elitist models of education established under colonialism.

A key feature of the changing educational landscape in Africa and other parts of the postcolonial world has been the emergence of NGOs as a major player in education and other areas of development. As Manji and O'Coill (2002, p. 568) put it, "NGOs today form a prominent part of the 'development machine', a vast institutional and disciplinary nexus of official agencies, practitioners, consultants, scholars and other miscellaneous experts producing and consuming knowledge about the "developing world"'. The authors explain, the emerging discourse of development in the period follow-

45 Illiteracy is identified by CESA as a major challenge to the adoption of scientific and technological innovations geared towards improvement in health, agriculture and livelihoods. The document argues that with one of the fastest growing population growth rates, if the rise in illiteracy is not stemmed, illiteracy may jeopardize economic and social progress on the continent. 
ing the Second World War provided a rationale for the emergence of two distinct types of $\mathrm{NGOs}^{46}$. However, in the immediate post-independence period, official development agencies remained unenthusiastic about the work of NGOs preferring to channel aid through the state. The work of NGOs in education as in other spheres was marginal and limited to project work.

The rise of neo-liberalism, and the good governance agenda, however, saw a change in attitude towards NGOs in which NGOs and other civil society organisations were often co-opted by international development agencies to a re-packaged programme of welfare provision. Increasing amounts of development assistance were channelled through $\mathrm{NGOs}^{47}$. This provided a safety net that served to legitimise the neoliberal state in which economic policies focused on austerity were increasingly determined by international financial institutions. This period saw a mushrooming of NGOs in Africa. According to Pinkney (2009), NGOs nowadays are concerned either with service delivery or with 'advocacy'. This duel function is evident in education with NGOs often making up some of the shortfall in educational provision and, increasingly with NGOs such as $\mathrm{UWEZO}^{48}$ in East Africa that enjoy significant donor support in holding governments to account for the quality of education. This duel function places NGOs in an ambiguous position vis a vis the state, legitimatory on the one hand and antagonistic on the other.

A key actor within civil society that has significantly impacted education and training systems since colonial times is the private sector. Private schools were present under colonialism, often serving the children of European settlers and indigenous elites. Private schools in the metropole and in the colonies provided a key entry point into the colonial administration and played a major socialising function in developing an esprit de corps for the colonial project (Mangan 1988). They were often allowed to flourish in the postcolonial era, providing a key institution for the reproduction of the class privilege

The first group consisted of overseas missionary societies and charitable bodies that were present in the colonies prior to independence. Christian Aid evolved out of an amalgam of such charities. The second group is typified by organisations such as Oxfam, Save the Children and Plan International that had no direct involvement in the colonies but rather emerged as 'war charities'. Each group had different motivations for adopting the development mantle.

47 In the early 1970 s less than two per cent of NGO income came from official donors. By the mid-1990s this figure had risen to 30 per cent (Manji/O'Coill 2002).

48 UWEZO means 'capability' in Kiswahili. It aims to improve literacy and numeracy among children in the basic education cycle through what it claims are citizen-driven approaches to accountability. UWEZO produces the results of a literacy and numeracy test that it administers annually so as to draw attention to poor learning outcomes in schools (see http://www.uwezo.net/). UWEZO often operates in an antagonistic relationship with Ministries of Education in the countries concerned. 
enjoyed by indigenous elites. An infamous example was Kamuzu school, built by Malawi's infamous dictator, Hastings Banda. A homage to British schooling, it consumed almost all of the country's education budget ${ }^{49}$.

As Ilon (1994) points out, as part of structural adjustment lending, policies supporting private schools and the introduction of user fees were introduced by many governments as part of a hollowing out of state provision. This led to middle class 'flight' from the system which in turn led to an increasing reluctance on the part of this group to pay taxes to support state schools. The consequence was a decline in the quality of government schools which in turn impacted negatively on enrolments. More recently, the privatisation agenda with the active backing of Western governments has led to the proliferation of low fee private schools targeted at low-income families. Virtually the entire basic education system in Liberia for example, has been outsourced to chains of foreign owned private providers. Available evidence is mixed concerning the impact of low fee private schools on learning outcomes in Africa and elsewhere (Day et al. 2014; Verger et al. 2016) and these schools often remain out of reach for the poorest. The unregulated expansion in the number of private providers has exacerbated the already fragmented and incoherent nature of many African education systems.

Providing continuity on a key rationale for the existence of private schools under colonialism and subsequently, CESA calls for a greater emphasis on privatisation in recognition of the high costs of educational expansion, particularly at higher levels of education and training. The privatisation of schooling continues to be a key mechanism for the reproduction of class and other inequalities. As such it militates against the notion of social and environmental justice outlined above through further providing a highly unequal set of institutional arrangements within which learners may realise capabilities and valued functionings.

Writing in the 1990s, and based on her analysis of the longer term impact of SAPs, Ilon (1994), an economist of education, painted a future scenario involving a growing gulf in educational opportunities between emerging global elites and the rest of the population. According to Ilon (p. 99), "a national system of schooling is likely to give way to local systems for the poor and global systems for the rich". Within this highly differentiated environment, a top tier will benefit from a private education that will make them globally competitive; a middle tier will receive a 'good' but not 'world class' education, whilst the majority, third tier, will have a local, state education that will make them "marginally competitive for low-skill jobs" (ibid., p. 102). In very large measure Ilon's predictions have been realised although with the caveat that millions of children on the continent still have no access 
to any form of education at all. It can be argued that this educational scenario, whilst having a negative correspondence with the longer-term aspirations for SD contained in Agenda 2063, actually enjoys a positive correspondence with the existing system of global capitalism in which African elites have limited access to economic opportunities and resources but the majority can expect a lifetime of poverty in the rural and urban areas with limited opportunities on the margins of the economy punctuated by long period of unemployment.

A further feature of the educational landscape in Africa in the past 20 years or so has been a proliferation of philanthropic private foundations. Foundations such as the Phelps-Stokes Foundation have had a role in providing education and on influencing policy on the continent since colonial times in the early part of the twentieth century. More recently and driven by diverse philanthropic and ideological motives, Foundations including the Hewlett Foundation, the Bill and Melinda Gates Foundation and Mastercard Foundation have played an increasingly prominent role in funding education and in shaping policy at a global scale, e.g. through their involvement in the Global Partnership for Education. They have also gone some way towards establishing their own epistemic communities (Haas 1989) in education and other areas as a means of exercising their productive power. As with NGOs, Foundations have also sought to play a role as innovators in the education system.

Besides advocating forms a role for the private sector in the provision of education CESA is silent on the role of civil society in the education sector. Given the role of civil society in education since colonial time this can be perceived as an omission. One way of interpreting the omission is in terms of the dual role of civil society organisations in providing services that might otherwise be provided by the state on the one hand and, on the other hand, challenging the state to be more accountable for service provision. Both of these roles stand in contradiction to the vision of state-led development that is encapsulated in Agenda 2063. As such they challenge entrenched interests within the state. Civil society has played a contradictory role also in realising social and environmental justice in education.

On the one hand faith-based organisations philanthropic organisations and NGOs can be seen to have contributed to distributive justice through the transfer of resources from the more prosperous global North to the Global South. It has also been suggested, however, that the privatisation of education supported by philanthropy, private capital and donors has exacerbated inequality in education along class lines. Further, faith-based organisations, Western NGOs and Foundations can also be seen to have undermined the goals of both recognitional justice through promoting Western cultures and ideologies at the expense of indigenous ones and participatory justice through their legitimatory role in processes of hollowing out of the state under neoliberalism. 
From a complexity perspective, the role of civil society can also be seen to have contributed to the increasing fragmentation and lack of coherence in education systems. In many African countries, for example, private schools remain largely unregulated and therefore outside of the ambit of national education policy (Day et al. 2014). This poses a real challenge for regional and national policy agendas.

\subsubsection{The domain of violence}

As Walby points out, the importance of violence for people's well-being, for regimes of inequality, and for other institutional domains, is much underestimated in social theory and is frequently rendered invisible. This is despite the regulation and deployment of violence "being part of the constitution of social order, complex inequalities and globalization" (Walby 2009, p. 190). Walby argues that violence needs to be understood in its full ontological depth, i.e. as an institutional domain and social system in its own right. Violence operates at different scales. It cannot be reduced to personal psychological aspects as is commonly the case in criminology for example. Rather it also needs to be seen as discursively constituted and a social practice that is itself constitutive of power and regimes of inequality. In this regard, violence may be perpetrated by states, individuals or groups. From the perspective of social and environmental justice, violence can be seen as a means to curtail the capabilities of groups, limiting their opportunities to flourish through incalculable physical and psychological trauma and injury. Conflict also causes enourmous damage to the environment and to other species curtailing the capability of natural environments to flourish.

Agenda 2063 goes some way to highlighting major threats to Africa's Peace and Security. It notes increases in the propensity to resort to the use of violence within communities linked to 'cultural, political, social and economic gaps between the minority at the center and the larger population - rural or urban and intergenerational disputes' and over 'failure to accommodate multiple community identities, especially at the local level, especially in fragile and conflict-affected areas'. At a state level, violence is linked in the report "to ineffective credible and legitimate democratic governance institutions for the prevention of violent conflicts; such as the rule of law, democratic access to power and effective wealth distribution" and to "limited state capacities leading to corruption lack of accountability and impunity, which restricts the provision of services" (AUC 2015, p. 66). The report also highlights new forms of criminal activity such as piracy and of religiously inspired conflict that cuts across national borders and to the "ease of trading, acquiring and circulating weapons" (AUC 2015, p. 66). Finally, the report draws attention to violence against women as a continent-wide problem. 
It can be seen that the FD goes some way towards recognising the ontological depth of violence, the multiple scales at which it operates, and it also tacitly acknowledges the implication of violence for inequalities including those based on rurality, class, gender and ethnicity. Violence is however, first and foremost identified as arising from inequalities within communities. In this way the FD elides the role of the state and of elites within the state in perpetuating violence to protect their own interests. This has an historical basis and is linked to globalisation.

Although the use of violence pre-dates the colonial encounter, colonialism was itself premised on violence. Whether it was the violent acquisition of territories, the forced removal of communities from their lands and livelihoods, the violence of slavery and of indentured servitude, the violent suppression of rebellion or the psychological trauma caused by the effects of institutionalised racism. The cold war fermented state sponsored violence through its role in propping up corrupt and often ethnically exclusive regimes promoting inter-ethnic conflict over land and resources. Neo-liberalism has fuelled inequalities and in turn contributed to conflict through the hollowing out of the state which has reduced the capacity of the state to prevent violence. It is in this context that the FD proposes a stronger role for the state in dealing with violence. However, this role is, in accordance with the good governance agenda, seen principally in terms of managing community-based conflict through sound institutional frameworks. It does not address the fundamentally political nature of violence and the extent to which in the postcolonial world violence is embedded in the nature of the state and linked to processes of globalisation.

Neither does the FD or CESA acknowledge the role of institutions such as the education system in perpetuating violence. Colonial education was complicit in perpetrating violence through a number of mechanisms that have remained remarkably obdurate. For example, the use of corporal punishment which was a hallmark of colonial education remains widespread despite the efforts of some governments driven by human rights concerns to outlaw its use. Gendered, sexualised violence is also widespread in many education systems (Leach 2004). From the colonial period, the implicit denigration and belittling of indigenous cultures, languages and forms of knowledge can be seen as a form of epistemic violence. Education since colonial times has also fuelled ethnically based violence through restricting access to education for some groups.

As commentators have noted, education has a Janus face with respect to conflict (Davies 2004; Bush/Salterelli 2000). It is complicit in perpetuating inequalities in access that can fuel violence and has been used by governments and civil society political projects to further their political ends. The other face is education's potential role in peace building through forms of peace education. Peace education has long been advocated as part of a rights- 
based approach to education. The CESA specifically mentions peace education as a means for preventing conflict. This is potentially positive. However, as Bush and Salterelli and others have noted, whilst peace education can play a positive effect in preventing violence it can only be part of a wider set of initiatives aimed at addressing the roots of conflict. It also needs to be linked to efforts to transform education systems themselves away from incubators of different forms of violence including corporal punishment, sexualised violence and epistemic violence.

\subsubsection{The social domain}

The FD gives a relatively high priority to the social domain, focusing in particularly on demographic change, poverty (particularly rural poverty), gender, health and education. It is noticeably silent on some forms of inequality including those relating to sexuality for example, perhaps reflecting the prevalence of conservative cultural norms and values. There are also silences in relation to other areas of inequality including indigenous groups and disability.

By way of context, the FD notes dramatic changes in Africa's demographic profile $^{50}$. In the period to 2063, the FD notes that the African population will increase far more rapidly than it will in the rest of the world population. A key feature of development in Africa is the rapid process of urbanisation. The FD estimates that more than two-thirds of the projected population of 2.5 billion will be living in urban centres by 2063 . It is also noted that Africa's population is young with a median age of about 20 years in 2014, compared to a world average of 30 years. This is seen in the report as both an opportunity and a challenge for education and training. A further demographic trend with implications is that of migration which is intense including rural-urban migration, opening up of borders, a growing trend of young Africans seeking a better life in Europe and elsewhere, and forced displacements, due to factors such as civil wars, droughts, water shortages and natural disasters.

In relation to poverty, the FD points out that there has been a reduction in absolute poverty in many African countries and that this is falling for the first time in a generation ${ }^{51}$. However, the report notes that poverty has worsened

50 The FD notes, for example, that since 1950, Africa's population size and growth has experienced an upward trend, growing from about 229 million to 1.2 billion in 2014, representing 9.1 and 15.1 per cent of the total world population respectively. This proportion is projected to increase to 19.7 and 35.3 per cent respectively by 2034 and 2100 (AUC 2015, p. 44).

51 The proportion of people living in extreme poverty (i.e. less than USD $1.25 /$ day) fell from 56.5 per cent in 1990 to 48.5 per cent in 2010 (AUC 2015, p. 31). Furthermore, it points 
in several other countries and that "overall, the gains remain fragile and reversible due to rising inequalities and exposure to shocks (economic, political, social and environmental)" (AUC 2015, p. 31) ${ }^{52}$. Linked to poverty is the prevalence of disease ${ }^{53}$. The report highlights rural poverty as a particular challenge. It links rural poverty in part to patterns of economic growth and to the limited growth within the agricultural sector ${ }^{54}$. Linked to the issue of rural poverty is the challenge of food insecurity. The report notes that with 60 per cent of the world's arable land, agriculture is Africa's greatest potential and can serve as the main engine to propel the continent's growth and transformation. However, "due to her high population growth, low and declining agricultural productivity, policy distortions, weak institutions and poor infrastructure, among others, Africa has turned into a net food importer, is currently importing nearly a quarter of her food needs. Consequently, one in four undernourished people in the world live in Africa" (AUC 2015, p. 31).

The FD identifies the development of the agricultural sector as the key means for addressing rural poverty and food insecurity. There are however tensions. Poverty is seen in the FD principally in absolute terms. The idea of inclusive growth contained in the FD is premised on the idea that growth will have a 'trickle down' effect in reducing absolute poverty. The tension here is between the rhetoric of agricultural development and the reality of extractive economic practices and land grabs which have increased inequalities in rural and urban areas (Ayers 2013). That is to say that in relation to redistributive justice, poverty needs to be seen in relative as well as absolute terms as an aspect of class and other intersecting regimes of inequality that have been in existence since colonial times.

For example, the introduction of mining under colonialism and the migratory system resulted in long periods of absence for African men. This in turn had the effect of disrupting family and kinship arrangements, diminishing men's roles in resource management and hugely increasing the workload of African women. It is in relation to the effects of colonial practices on rural

out that a number of countries have reached, or are close to reaching, the MDG target of halving poverty by 2015 .

52 Despite progress, the report states that Africa remains the continent with the highest concentration of poverty with the number of Africans living below the poverty line in fact increasing from 290 million in 1990 to 376 million in 1999 to 414 million in 2010.

53 The framework document notes that although infectious diseases as a cause of mortality and morbidity have declined in the rest of the world, these remain as the most frequent causes of deaths in Africa due to poor environmental management, weak water and sanitation systems and low knowledge of basic health household practices.

It is noted that "agricultural/rural population in Africa stands at 530 million people, and is expected to exceed 580 million by 2020 . About 48per cent of this population relies directly on agriculture for economic and livelihood needs". It is noted that "agricultural performance is central in driving socio-economic transformation, especially in the traditionally economically marginalized and largely rural populations" (AUC 2015, p. 45). 
poverty and social relations that the salience of the 'land question' in panAfricanist thought emerged as a basis for grass roots political mobilisation and demands for recognitional justice (Moyo 2015). It is also the case that the vast majority of rural workers are women and are often amongst the poorest. In the context of SAPs they also had to 'take up the slack' of cuts in services such as health and education as feminist critiques of SAPS have illustrated (see for example Sparr 1994). The undermining of African rural livelihoods also contributed to urbanisation with all of the environmental and social problems that ensued. There is also an unaddressed tension in the links made in the FD between population growth and poverty. Whilst there are clearly challenges involved in dealing with social consequences of large population growth, there is a need to treat such links with caution. There is a long history in development discourse of locating the causes of poverty in Africa to population growth rather than in the unequal nature of the economy and polity ${ }^{55}$.

Education is deeply implicated in the FD and CESA in playing a role in addressing both population growth and youth unemployment in the rural areas. In particular, CESA emphasises the role of a revitalised TVET sector in providing the skills relevant for sustainable rural livelihoods and the role of adult literacy in tackling disease and poverty and giving women greater control over their fertility. These are consistent with a rights-based approach to education and with the vision of social and environmental justice described above in that they aim to expand the capabilities of young people and women in rural areas. As suggested earlier, however, education is implicated in perpetuating the conditions that give rise to poverty through acting as a mechanism for reproducing unequal class and gender relations. It can also be seen to have contributed to rural/ urban inequalities since colonial times through the emphasis on developing urban elites. (It remains the case that the majority of secondary schools are to be found in urban areas which contributes to processes of urbanisation). As part of a vicious cycle it is also difficult to recruit good quality teachers to work in impoverished rural areas. These tensions and challenges are not addressed in CESA. For example, there is little emphasis on how to attract and retain good quality teachers to rural areas.

In relation to gender equality, the FD notes progress in improving the political representation of women. It notes that with an average of 21 per cent of parliamentarians as women, Africa is the only region to double women's political participation in one decade - at 64 per cent, Rwanda is the country with the highest percentage of female parliamentarians in the world'. It also notes improvements in women enrolment in basic education. These gains have not, however, reduced inequalities between men and women, especially with respect to access and control of economic resources, as well as in labour 
market participation or reproductive rights (maternal mortality and fertility). Women constitute the majority of those holding vulnerable jobs (i.e. poor wages and working conditions) $)^{56}$ and gender inequality is one root cause of Africa's poor performance with respect to poverty reduction. It is claimed that the continued monopoly of power by male political elites, a lack of political will, socio-economic challenges, the non-recognition of unpaid care and domestic work, as well as patriarchal traditions and beliefs continue to limit the formal and meaningful involvement of women in governance, peace and security and development processes and that the continent cannot meet its ambitious goals under Agenda 2063 while it limits a dynamic segment of its society, which women represent, from realising its full potential ${ }^{57}$.

There are other silences too linked to the social domain such as the increasing mobility of youth as a consequence of poverty and conflict. It might be expected for example, from a rights-based perspective, that a regional agenda would be well placed to tackle issues of transnational migration but there is a silence around these issues. Rather the focus is on the development of continental and sub-regional integration schemes as a means to promote the mobility of students and workers, i.e. as a contribution to the mobility of human capital. Whilst this is important in its own right, the emphasis is on economic factors rather than on finding regional solutions to tackling the humanitarian crisis brought on by war, conflict and poverty.

\subsubsection{The cultural domain}

The pan-African influence in the FD is perhaps most evident in relation to discussions about the cultural domain. The report notes the effects of cultural domination during the slave trade and colonial era which it is claimed "led to the depersonalization on the part of African peoples, falsified their history, systematically disparaged and combatted African values and tried to replace progressively and officially their languages by that of the colonized" (AUC 2015 , p. 68$)^{58}$. Education is singled out as having accelerated Africa's inte-

ILO classified 84 per cent of jobs held by women in 2012 as vulnerable as compared to 70.6 per cent for men.

57 Investing in women and girls and their integration into the labour market, alongside delayed marriage and child bearing and expanded access to education for girls, family planning and sexual and reproductive health rights, has been attributed as the driving forces behind the economic successes of the 'Asian tigers'.

58 The document notes that work done by great African scholars and writers have contributed a lot to re-examining and restoring Africa's distorted and obscured place in the history of the world. The document also notes that despite her rich cultural heritage, Africa is poorly represented in the list of protected world cultural heritage sites and that this risks hastening the erosion of these sites. 
gration into a Western, global culture along with news media, music and art. The report argues that while Western influences can enrich the African cultural heritage, "they can also be a source of erosion and ultimately can supplant and replace African values and ethics" (ibid.).

The FD states that "language is at the heart of a people's culture and the acceleration of Africa's socio-economic transformation is impossible without harnessing in a practical manner the indigenous African languages" (AUC 2015, p. 68). Significantly, it goes on to argue that a 'major threat to African culture and heritage is the educational system which is marginalizing African languages' although as we shall see, this is not carried through in the CESA document. The FD identifies poor management of Africa's diversity - ethnic, religious, cultural - as being a source of conflict, on the continent. It also identifies religious extremism including Boko Haram in Northern Nigeria and the Lord's Resistance Army (LRA) in Uganda as examples of what can happen on account of this mismanagement.

At a discursive level, a key rationale for colonialism was in terms of the so-called 'civilising mission' of the white man (sic) ${ }^{59}$. Underpinning this view however, lay different explanations. Some of these were founded on a reading of the bible and particularly the old testament in which Africans are portrayed as heathens and as 'hewers of wood and drawers of water'. This particular reading of the old testament was influential, for example, in legitimising apartheid in South Africa (Tikly 1994). Also influential were changing discourses around race, nation and culture that assumed the biological and cultural inferiority of the non-European 'other' ${ }^{60}$. As Williams and Young (2009) have argued, in the lead up to independence, the civilising mission of whites was increasingly articulated with a modernist view of progress in which educated, African elites were seen as indigenous agents of modernity.

This modernist, universalistic view of progress provided a source of contradiction with the virulent forms of religious, racial and cultural racism with which it co-evolved. As Franz Fanon along with many other anti-colonial activists and advocates of Pan-Africanism have pointed out this has had a

59 Various scholars have argued that disability as a classificatory system for assigning difference can be traced back to the colonial encounter. There was often an overlap between depictions of the racial other and notions of deformity/ disability in western popular culture (Grech/Soldatic 2015).

60 These terms can be understood as floating signifiers with fluid boundaries between the way that they were deployed and what they were intended to signify (i.e. so-called 'races' were also often considered to have distinct cultures and to belong to different 'nations' - the $\mathrm{Zu}$ lu, Shona, Khosa, Tswana nations etc). In the context of the growth of the Eugenics movement in the late nineteenth century, the inferiority of Africans was underpinned by a virulent scientific racism that posited a hierarchy between the races with white, aristocratic Europeans at the top and Africans at the bottom of the hierarchy (Gould 1996; Loomba 2005). 
long lasting, negative effect on the African psyche, leading to a situation where Africans have at times rejected their own cultural values in favour of European ones and, so it is argued, have been complicit in their own subjugation (see for example Fanon 1961, 1986). Where the FD is more silent, however, is in the role of Western culture in processes of indigenous elite formation since colonial times.

Discourses about 'race' were also central to emerging ideas about 'development'. Commentators have argued that what Truman's speech represented was a break or disjuncture in the way that 'development' was understood but one that continued to provide continuity on development under colonialism. Whereas development had in the past been a 'natural' phenomenon, in the emerging hegemonic worldview, development became something that could be performed by one actor or region over another actor or region. Further, whereas colonisers and colonised had previously belonged to two different universes, separated by a gulf of biological and cultural difference, the new binary represented a step in the reinvention of the 'Third World' as part of a continuity with the West (Escobar 1995). Furthermore, whereas classical colonialism was premised on the view that although the 'natives' could be 'civilised' to some degree, they could never achieve equality with the West, in 'development' discourse, it became possible for underdeveloped regions and populations to evolve into developed ones. This did not mean, however, that the previously colonised were now seen as cultural 'equals' with the West, at least until they had become more 'westernised' (Rist 1997).

As the FD notes, education has historically been a key institution for the imposition of Western cultural hegemony. Thus overall the colonial curriculum introduced a Western episteme (ground base of knowledge) which differed considerably from indigenous knowledge systems but also from other forms of education in Africa such as Qur'anic education (Launey 2016). Similarly, in relation to assessment, the introduction of competitive examinations in the context of a highly selective education system stood in contrast to the role of assessment in traditional African education which focused on demonstrating relevant knowledge and skills on the job to ones elders and peers (Rodney 1973). In brief, at a cultural level, education was complicit in the spreading of a Western views of modernity that were seen as superior both to African cultures and religions and to Islam which had been long established on the continent thanks to earlier waves of globalisation.

Where the FD is less explicit is in identifying the role of Western education in the process of elite formation. As noted above, the French approach was more assimilationist in their orientation towards education ${ }^{61}$. A key com-

61 In the eyes of the French, the policy of assimilation was based on a very real need: "The black races of Africa have not attained a complete and coherent civilization of their own, nor do they possess the necessary foundations on which to build up a real system of educa- 
ponent of the approach was the use of French as the medium of instruction at all levels of the education system ${ }^{62}$. Whilst there was an emphasis on a curriculum more suited to the rural areas at primary level, there existed a stronger emphasis on the 'formation' of African elites into French culture through secondary and latterly tertiary education (from the turn of the twentieth century up to independence this policy became one of 'association' aimed explicitly at developing modern African elites who could assume leadership roles albeit in the French image). The British by way of contrast, explicitly pursued a policy of 'adapted education'. This meant teaching in the mother tongue at primary level and a curriculum "adapted to the mentality, aptitudes, occupations and traditions of the various peoples" and particularly focused on developing agricultural and other skills suited to life in the rural areas (White 1996 , p. 19$)^{63}$ but promoting English at secondary and tertiary level ${ }^{64}$.

The Eurocentric and elitist nature of colonial schooling has proved remarkably enduring. The advent of modernisation theory continued to equate good quality education with a Western view of modernity and this continued to imply a Western curriculum. Interestingly, the FD advocates a target that "at least 80 per cent of content in educational curriculum is on indigenous African culture, values and language targeting primary and secondary schools by 2030" (AUC 2015, p. 157). This is not reflected in the more conservative

tion. The great contribution that we can make lies precisely in the interweaving and blending of primitive civilizations with our own universally applicable civilization, which will have to justify its position of superiority and authority by the manner in which it acquits itself of the responsibility it has assumed" (Charlton, in White 1996, p. 15).

62 As White (1996) explains, the use of French was explicitly justified by the French colonialists at the time with reference to the underlying view of the technical inferiority of African languages and in order to make African more employable - themes that are remarkably similar to themes in contemporary discourses around the instrumental role of language of instruction (Tikly 2016).

63 The view of adapted education was based on notions of cultural relativism in contrast to the cultural universalism of the French. In this view, African cultures could at times be valorised.

64 At a more instrumental level, part of the rationale for adapted education as Whitehead explains, was to circumvent a situation similar to the one in India in which there were limited employment opportunities for Western educated Indians leading to resentment and rebellion. Unlike the French tradition the British also instituted technical and vocational education and training although this was always much debated and remained so into the postcolonial period. There were also differences between the French and British as the two major colonising powers about how the outcomes colonial education might be evaluated. For the French, whilst there was a need to account for expenditure, the 'success' of colonial education lay largely in the success or otherwise of its assimilationist project and quality was very much equated with exposure of elites to the academic rigour of the French curriculum. By way of contrast and as a precursor to the later emphasis placed on rates of return analysis in anglo-American policy, the quality of education in the English system was more likely to be equated with efficiency and the need to avoid wastage of money and human material (read human capital) (White 2006). 
CESA document, however, where, as we have seen, the emphasis is on science and mathematics with no mention of the development of indigenous knowledge in the strategic objectives.

Walby (2009) also draws attention to processes of 'glocalisation' in which as an aspect of contemporary globalisation, emergent forms of global civil societal practices as well as cultures are framed by the global. This leads to hybrid cultural forms and identities rather than to the homogenisation of culture. This is important to grasp in the postcolonial world where the commercialisation and spread of Western languages, religions, forms of knowledge and popular culture is not uniform in its effects but co-evolves with a reassertion in some instances of indigenous cultural forms.

However, glocalisation of culture clearly does not involve the coming together of different cultures and identities on an equal basis. Rather hybridization needs to be seen in historical context in terms of the productive power of the West since colonial times in defining the nature of modernity even though these understandings have been challenged and resisted. It draws attention to the importance of recognising different epistemologies of the South (de Sousa Santos 2012) in defining the curriculum. It also draws attention, however, to raising awareness of the interpenetration of cultural forms over many centuries including the debt owed by so-called Western culture to African and Asiatic civilisations (Bernal 1989). It warns against an essentialised, conservative view of either Western or African cultures as being fixed in time and immutable. It also involves stepping back from a position in which African cultures are 'valorised' in antithesis to Western cultures in a way that ignores the potential role of indigenous cultures in reproducing forms of inequality including conservative cultural norms and values around gender, sexuality, disability etc. that have been oppressive in their effects.

The above discussion suggests a potentially pivotal role for education in developing contemporary understanding of African cultures and languages in a way that recognizes the enormous cultural resources of the continent without falling into a naïve relativism about the effects of different cultural traditions and the constantly emergent and hybrid nature of African cultural forms and identities. It is also useful for framing contemporary debates including those around 'decolonising the curriculum'. It also suggests a pivotal role for universities in re-orienting research on the continent to focus on African development which it has been suggested elsewhere should lie at the heart of the African Renaissance project (Tikly 2003) ${ }^{65}$. Rather, the emphasis in CE$\mathrm{SA}$ is on the role of universities in supporting economic development through

At its most simple it signals a 'rebirth' of the African continent in economic, political and social terms and the projection of African humanism based on the collective, peoplecentred and spiritual nature of the African personality captured buy concepts such as ubuntu onto the global stage (Tikly 2003). 
promoting science and mathematics, innovation and enterprise without problematising the cultural basis of the curriculum.

CESA is also silent on the language question except in relation to the early years. The pattern of early exit from the mother tongue (i.e. a subtractive bilingual approach) is very widespread. It reflects the view amongst many parents and policy makers that a good quality education means learning in a European language and the association particularly between competence in English and access to elite jobs (Trudell 2009). This is despite the evidence that learning in the mother tongue for at least eight years and learning a global language as a second language (i.e. an additive bilingual model) is far more effective for conceptual and linguistic development, particularly for learners from disadvantaged backgrounds (e.g. Heugh 2005). A key effect of these omissions is to continue to reinforce a separation between predominantly Western oriented elites, fluent in European languages who reside largely in the urban areas and the urban and rural poor who have not been Westernised to the same extent.

\subsubsection{The Environmental Domain}

The FD identifies Africa's natural resources as playing a critical role for vast segments of Africa's population who depend on the continent's biodiversity, forests and land for their livelihoods directly or indirectly. The document points out that Africa is well endowed with biodiversity: both variety and abundance of species, ecosystems and genetic resources. The document highlights the blue/ ocean economy as having importance in environmental, economic and social terms ${ }^{66}$. The FD identifies natural resources as playing a critical role for vast segments of Africa's population who depend on the continent's biodiversity, forests, land and waters for their livelihoods directly or indirectly. These natural resources, it is argued, also make a direct contribution to economic development through tourism, agriculture, logging, fishing and other activities. However, the FD notes that the continent's biodiversity, land and forests are facing increasing challenges ${ }^{67}$. The report highlights

66 It states, for example, that "Africa's bodies of water are endowed with abundant flora and fauna and marine ecosystems including diverse fish and other aquatic life, coral reefs; and are also sources of livelihoods to many Africans including water, food, power generation and transportation. Coastal areas and lake basins have also emerged not only as major tourist attractions but also as important sources of minerals, including oil and gas. The sector creates jobs for 7.1 million fishers $(2.7$ million in marine fisheries and 3.4 million in inland fisheries and 1 million in aquaculture) and over 59 per cent of these people are women" (AUC 2015, p. 51).

67 These include habitat loss as the major factor behind biodiversity loss and accelerating erosion of the genetic resources of agricultural plants and animals. The erosion of genetic 
unequal distribution of land, with small farmers pushed out to marginal areas by large investment programs, severe soil degradation, desertification and deforestation $^{68}$ accompanied by flooding and intermittent droughts. Significantly and in keeping with the analysis presented below, the document names the recent 'scramble for Africa's land' by big investors (mostly foreign) in bio-fuels, minerals and oil, as well as food production for consumption abroad as a major risk to environmental protection and sustainable economic development. In relation to the blue/ ocean economy, the report states that the dumping of toxic waste, illegal trafficking, oil spills, degradation of the marine environment, transnational organized crimes, among others, have seriously threatened Africa's oceans, seas and lakes ${ }^{69}$. Finally, the FD draws attention to the abundance of energy sources on the continent including crude oil and natural gas with huge potential for hydropower, geothermal energy, solar and wind power ${ }^{70}$ but notes that Africa's energy profile is characterized by low production, low consumption, and high dependence on traditional biomass energy and that despite the huge energy resources ${ }^{71}$.

The devastating social and environmental consequences of extractive economic practices noted in the FD can also be traced back to colonial times. As economic historians have argued (see for example Akyeampong et al. 2014; Ghai 1992), changes in the economy brought about by colonialism had

resources leads to growing genetic uniformity of agricultural plants and animals, which means an increased risk of food loss from major epidemics.

68 Linked to these developments as well as to global warming are issues of land degradation and desertification which are believed to impact 43 per cent of Africa's land surface with serious environmental and socio-economic consequences. Similarly, the report notes that the continent lost over 4 million hectares of forests annually over the past two decades due to extensive agricultural practices, unregulated and unsustainable wood harvesting and illegal commercial logging.

69 These problems, it is argued are "compounded by the aggravated effects of climate change, most notably the rising ocean temperatures and ocean acidification that is leading to the weakening of the capacity of the ocean carbon sink and loss of fishery resources, and also reduction in the size of water bodies, such as Lake Chad" (AUC 2015, p. 51).

70 "Crude oil reserves estimated at over 130 billion barrels - about 9.5 per cent of world's reserves; about 8 per cent of the world's total reserves of natural gas estimated at about 15 trillion cubic metres; about 4 per cent of the world's total proven reserves (about 95 per cent of these reserves found in Southern Africa); hydropower resources potential to generate over 1,800 TWh/yr of electricity; geothermal energy potential estimated at over 15,000 MW; and huge solar and wind power potential. Because of its proximity to the Equator, Africa has also the world's highest average amount of solar radiation each year. Africa's bioenergy potential is immense, particularly given rapid advances in research that have brought new energy crops into production and second-generation lingo-cellulosic technologies within reach in less than a decade" (AUC 2015, p. 51).

71 The report argues that the continent faces enormous energy challenges including low generation capacity and efficiency, high costs, unstable and unreliable energy supplies, low access to modern energy, insufficient energy infrastructure, and lack of institutional and technical capacity to harness huge resources. 
a significant impact on environmental degradation and disrupted the longestablished systems of resource management which had relied on shifting cultivation and nomadic pastoralism. The annexation and centralisation of sovereignty over forests, farm lands, lakes and rivers also laid the foundations for environmental degradation as colonial administrations, unlike traditional authorities often lacked the capacity to exercise effective control over resource management. The search for profits often undermined traditional agricultural practices such as crop rotation which had protected the soil and the introduction of foreign crops such as groundnuts and cotton further reduced soil fertility. It also served to confine indigenous populations to areas with least agricultural potential. Different methods involving various degrees of coercion were used to secure labour on European farms, plantations and mines (Ghai 1992).

As noted in the FD, the continent continues to face huge environmental challenges from drought to deforestation to soil erosion, desertification, pollution and toxic waste dumping. A very real manifestation of the impact of the new scramble for Africa coupled with processes of global warming has been the speeding up of processes of environmental degradation on the continent (Ayers 2013). Furthermore, in spite of agreements made in the UN Stockholm Declaration or at the Basel Convention, practices such as the dumping of over five hundred tons of toxic waste in Abidjan, Côte d'Ivoire in 2006 - coined as 'toxic colonialism' by Greenpeace - assumes disproportionate risks between 'developed' and 'underdeveloped' countries (Pratt 2011). For some exponents of neoliberalism, environmental degradation is seen as a form of collateral damage ${ }^{72}$. In the meantime, a lack of investment in renewable sources of energy in which Africa is abundant (from solar power to biofuel) has increased dependency on fossil fuels which is contributing heavily to processes of deforestation. There is a contradiction, therefore, between the rhetoric of the FD and the realities of neo-liberal policies on the continent. It is too early to say whether the environmentalist agenda contained in the FD will be effectual in the face of these contradictions.

72 For some exponent of neoliberalism, environmental degradation can be seen as a form of collateral damage. In an internal memo, written by the Chief Economist for the World Bank in 1991, Lawrence Summers, toxic waste dumping is seen precisely in these terms: "Just between you and me, shouldn't the World Bank be encouraging more migration of dirty industries to the LDCs?... The economic logic behind dumping a load of toxic waste in the lowest wage country is impeccable, and we should face up to that... Under-populated countries in Africa are vastly under-polluted; their air quality is probably vastly inefficiently low compared to Los Angeles or Mexico City... The concern over an agent that causes a one in a million change in the odds of prostate cancer is obviously going to be much higher in a country where people survive to get prostate cancer than in a country where under-five mortality is 200 per thousand" (Shiva 2000, p. 65). 
Education has had a contradictory relationship with the history of environmental degradation on the continent. There has been an emphasis on the teaching of agriculture as part of 'adapted education' and then in the postindependence period as a school subject. Agricultural Education and Training is also a recognised part of the TVET and Higher Education sectors although there have been concerns about its quality and relevance (AU 2007). There is also a long history of environmental education in Africa. This was given impetus by the decade for Education for Sustainable Development although the overall reach of environmental education initiatives remains limited (Lotz-Sisitka et al. 2017). Education has also contributed to processes of environmental degradation for example, by being complicit in encouraging urbanisation (above) and through its academic bias which has meant that agricultural and environmental education has not been afforded a high status. It is therefore unfortunate that CESA makes little mention of these subjects or indeed of a broader conception of ESD that would embrace environmental, economic and social dimensions of the challenges facing the continent. This suggests that enormous challenges lie ahead in Africa as elsewhere to ensure a holistic conception of ESD gets instituted in the curriculum.

\subsection{Towards a transformative agenda}

The above analysis serves to highlight the contradictory nature of different discourses about SD and ESD in Africa as elsewhere (Blewitt 2008). It has been suggested for instance that there are differences and contradictions between discourses of pan-Africanism, inclusive growth, human rights and environmentalism in terms of their views of modernity and by implication of $\mathrm{SD}$ and ESD. It has been argued that of these discourses, it is those relating to inclusive growth that predominate and that this leads to an emphasis on the instrumentalist role of schooling. The dominance of economistic discourses has been linked in the discussion above to the dominance of global and indigenous elite interests in regional policy agendas such as Agenda 2063. There are also fundamental contradictions, however between the ideas of SD and ESD contained in the document and the reality of neoliberal globalisation. These contradictions call into question the extent to which regional agendas can be understood as transformative. It also raises questions about what a transformative agenda might indeed look like.

A starting point it has been suggested is to consider the development of SD and ESD in relation to an understanding of social and environmental justice and such a view has been outlined in the paper. This involves understanding the role of education in supporting the development of valued capabilities and functionings for existing and future generations and recognising 
the capabilities of other species and natural systems. Crucially, it also involves overcoming the institutional and discursive barriers that prevent the realisation of valued capabilities. Here it has been argued that these barriers lie in the nature of the colonial legacy on the one hand and in the nature of Africa's position in relation to contemporary globalisation on the other hand.

A transformative SD and ESD will need to build from existing initiatives if it is to have purchase and achieve ownership amongst different stakeholders. In this sense, it is important to once again acknowledge the contested nature of the documents and the extent to which they contain within them the seeds of a transformative SD and ESD. For example, there is a recognition as noted of the harmful effects to society and to the environment of untrammeled market forces even if these are not properly addressed in policy recommendations. There is also recognition of the importance of promoting African cultures and languages including indigenous knowledge in the FD even if this does not subsequently appear in the CESA. Finally, there is some recognition of the importance of a holistic approach to skills development in CESA which emphasises a range of skills necessary for economic and social development and for environmental protection. However, the emphasis is on a rather narrow set of skills including the development of basic literacy and science and maths as well as on peace education. Other kinds of skills, for example linked to promoting environmental understanding and developing creativity are not mentioned although they are critical for human development and environmental protection. Further, whilst attention is given to the role of education in poverty reduction and gender quality, there are omissions around other areas of disadvantage including sexuality and disability.

A source of inspiration in imagining what a transformative ESD might look like comes from history. In his classic text How Europe Underdeveloped Africa, Walter Rodney (1972) describes the following features of pre-colonial African education as 'outstanding':

“... its close links with social life, both in a material and spiritual sense; its collective nature; its many sidedness; and its progressive development in conformity with the successive stages of physical, emotional and mental development of the child. There was no separation of education and productive activity or any division between manual and intellectual education. Altogether, through mainly informal means, pre-colonial education matched the realities of pre-colonial African society and produced well-rounded personalities to fit into that society." (Rodney 1973, p. 262)

Rodney's account is useful in that it helps to place pre-colonial education into a broader historical and material context ${ }^{73}$ and because it serves to demon-

73 In particular, Rodney links the development of more formal specialisation in pre-colonial skills formation (iron-making, cloth manufacture, pottery moulding, professional training as well as religious, medicinal and military instruction) to shifts in the mode of production (pre-Feudal to Feudal) before the Europeans arrived. 
strate the possibility for a positive correspondence between education and sustainable livelihoods. This stands in stark contrast to the largely positive correspondence between education policy and unsustainable development since colonial times.

More recently there has been a long tradition of environmental education and education for sustainable development on the African continent on which to build that has emphasized the importance of developing curricula and pedagogical approaches that can sensitise learners in a holistic way to the opportunities and challenges of SD. Lotz-Sisitka et al. (2017) have recently summarized some of the starting assumptions behind many of these initiatives as follows:

- ESD learning processes change the focus on learning to 'learning as connection' and a foregrounding of meaning making in the learning process as basis for efficacy and inclusivity. This requires a wider engagement with different ways of knowing, or inter-epistemological dialogues, and changes in pedagogy.

- ESD learning processes can enhance learners' capabilities (abilities to express and make choices about valued beings and doings), critical thinking and action competence (abilities to act) and agency (evidence of action). This requires different forms of pedagogy, but it is notable that there is a high level of interest in these forms of pedagogy and these outcomes of education amongst ESD practitioners on the continent. This is because these approaches all foster change or change oriented learning. Pedagogical models exist to support such approaches to learning, and these have been tried out and tested in a number of settings.

- ESD learning processes can enhance relevance of education. This can take place, for example, through various strategies such as including ESD topics in localised curricula and through place-based educational activities or use of local audits. Relevance of education is not simply local, but involves learners in hybrid relationships between the local and the global and in identity formations and negotiating of directions and purposes for engaging in educational activities. ESD learning processes support such initiatives (Lotz-Sisitka et al. 2017, p. 87-89).

These principles, it is suggested provide a good starting point for African-led research into what a genuinely transformative ESD might look like on the continent.

Furthermore, dominant economistic discourses from modernisation to human capital theory have often assumed that investing in education can lead to economic growth. This is an idealistic view of education as a panacea for development but also one that does not consider the complex nature of globalisation and of crisis. In this sense, it is important to recognise that ESD on its own cannot realise a transformative SD. As has been suggested, the roots 
of unsustainable development lie in the co-evolution of a range of economic, political, cultural and environmental factors. If education is to play a transformative role this can only be achieved if it is articulated in a coherent way with other key aspects of economic, political and environmental policy.

This in turn raises questions about the nature of the policy-making process itself and the use of evidence to inform policy. Policy-making in Africa as elsewhere is often dominated by a technical-rational approach based on the implementation of objectives typically contained in five-year plans. At an empirical level, the kinds of evidence that are valorised are those arising from the 'what works' agenda which is itself increasingly based on the use of randomised control trials and other kinds of quasi-experimental methodologies. As has been argued elsewhere (Tikly 2015; Byrne/Callaghan 2014), given the inherently unpredictable and non-linear nature of change within complex systems, this kind of evidence can give only limited understanding of how change might be brought about. These kinds of study provide a 'surface actuality', i.e. an indication, depending on the rigour of the studies themselves of the existence of correlations between variables that appear to be implicated in change. They do not say much about the causality. Rather, more research is required as to how policy makers get involved in iterative processes of problem-based policy making and are empowered to draw on a range of different kinds of evidence as a spur to action. There is also a ned to guard against the uncritical transfer of policy based on evidence derived in other contexts. Of importance here is the need to empower African based researchers to develop evidence of successful practice in SD and ESD rather than rely on the army of externally based 'experts' and consultants that are often literally flown in to help draft policy.

Realising a transformative vision for ESD presents considerable challenges, given the path dependency of education systems towards supporting unsustainable development since colonial times. It is also important, however, not to be overly fatalistic and to recognise the contested nature of regional and global agendas in the postcolonial period. As we have seen, the development of pan-Africanism, for example, has been marked by alternative visions of capitalist, socialist and other kinds of modernity albeit within an overall commitment to African unity. This offers some hope for a transformative SD and ESD but also indicates the importance of struggle and advocacy on the part of civil society organisations and policy makers committed to such a vision at a number of scales. 


\section{References}

Akyeampong, E./Bates, R./Nunn, N./Robinson, J. (2014): Africa's Development in Historical Perspective. Cambridge: Cambridge University Press.

Altbach, P./Kelly, G. (1978): Education and Colonialism. New York: Longman.

Andrews, M./Pritchett, L./Woolcock, M. (2017): Building State Capability: Evidence, analysis, action. Oxford: Oxford University Press.

AU (African Union) (2007): Strategy to Revitalize Technical and Vocational Education and Training (TVET) in Africa. Addis Ababa: African Union.

AU (African Union) (2015): Continental Education Strategy for Africa. Addis Ababa: African Union.

AUC (African Union Commission) (2015): Agenda 2063 Framework Document: The Africa We Want. https://www.un.org/en/africa/osaa/pdf/au/agenda2063framework.pdf [access: 2 May 2019].

Ayers, A. (2013): Beyond Myths, Lies and Stereotypes: The Political Economy of a 'New Scramble for Africa'. In: New Political Economy 18(2): 227-257.

Ball, S./Maguire, M./Braun, A. (2012): How Schools do Policy: Policy enactment in secondary schools. London: Routledge.

Barnett, M./Duvall, R. (2005): Power in Global Governance, International Organization. Cambridge: Cambridge University Press.

Bayart, J. (2009): The State in Africa: The politics of the belly. 2nd English Edition ed. London: Polity Press.

Bernal, M. (1989): Black Athena The Afroasiatic Roots of Classical Civilisation: The fabrication of ancient Greece 1785-1985. New Jersey: Rutgers University Press.

Biko, S. (1978): I Write What I Like. London: Bowerdean Press.

Blewitt, J. (2008): Understanding Sustainable Development. London: Earthscan.

Blewitt, J. (2018): Understanding Sustainable Development. Third edition ed. London: Routledge.

Bush, K./Salterelli, D. (2000): The Two Faces of Education in Ethnic Conflict: Towards a Peacebuilding Education for Children. Rome: UNICEF.

Byrne, D./Callaghan, G. (2014): Complexity Theory and the Social Sciences: The state of the art. London: Routledge.

Cairney, P. (2012): Understanding Public Policy: Theories and Issues. Basingstoke: Palgrave Macmillan.

Carney, S. (2008): Negotiating Policy in an Age of Globalisation: Exploring educational "policyscapes" in Denmark, Nepal and China. In: Comparative Education Review 53(1): 63-88.

Cowan, L./O'Connell, J./Scanlon, D. (1965): Education and Nation Building in Africa. New York: Frederick A. Praeger Publishers.

Davies, L. (2004): Conflict and Education: Complexity and Chaos. London: Routledge. 
Davies, L. (2008): Interruptive Democracy in Education. In: Zajda, J./Davies, L./ Majhanovich, S. (eds.): Comparative and Global Pedagogies. Equity, Access and Democracy in Education. Dordrecht: Springer, pp. 15-31.

Day, L./Mcloughlin, C./Aslam, M./Engel, J./Wales, J./Rawal, S./Batley, R./Kingdon, G./Nicolai, S./Rose, P. (2014): The role and impact of private schools in developing countries: a rigorous review of the evidence. London: Department for International Development.

De Jaeghere, J. (2017): Educating Entrepreneurial Citizens: Neoliberalism and youth livelihoods in Tanzania. London: Routledge.

de Sousa Santos, B. (2012): The Public Sphere and Epistemologies of the South. In: African Development XXXVII(1): 43-68.

Elliot, J. (2013): An Introduction to Sustainable Development. 4th Edition ed. London: Routledge.

Eltis, D./Richardson, D. (2008): Extending the Frontiers: Essays on the new transatlantic trade database. Newhaven: Yale University Press.

Escobar, A. (1995): Encountering Development, The Making and Unmaking of the Third World. Princeton, New Jersey: Princeton University Press.

Fanon, F. (1961): The Wretched of the Earth. London: Penguin.

Fanon, F. (1986): Black Skins White Masks. London: Pluto Press.

Ferguson, J. (2006): Global shadows: Africa in the neoliberal world order. Durham NC: Duke University Press.

Frank, A. (1970): Latin America: Underdevelopment or Revolution. New York: Monthly Review Press.

Fraser, N. (2008): Scales of justice: Re-imagining political space in a globalising world. Cambridge: Polity Press.

Gaitskell, D. (1988): Race, Gender and Imperialism: A Century of Black Girls' Education in South Africa. Johannesburg: University of the Witwatersrand.

Ghai, D. (1992): Conservation, Livelihood and Democracy: Social dynamics of environmental changes in Africa. Geneva: UNRISD.

Gould, S. (1996): The Mismeasure of Man. London: w.w. Norton.

Gramsci, A. (1992): Prison notebooks, volume 1. New York: Columbia University Press.

Grech, S./Soldatic, K. (2015): Disability and Colonialism: (Dis)encounters and anxious intersectionalities. In: Social Identities: Journal for the Study of Race, Nation and Culture 21(1): 1-5.

Haas, P. (1989): Do Regimes Matter? Epistemic Communities and Mediterranean Pollution Control. In: International Organization 43: 377-403.

Harvey, D. (2003): The New Imperialism. OUP.

Harvey, D. (2011): The Enigma of Capital And the Crises of Capitalism. London: Profile Books.

Held, D./McGrew, A./Goldblatt, D./Perraton, J. (1999): Global Transformations politics, economics and culture. Cambridge: Polity Press. 
Herbst, J. (2000): States and Power in Africa: Comparative lessons in authority and control. 2nd edition ed. Princeton: Princeton University Press.

Heugh, K. (2005): The Case for Additive Bilingual/ Multilingual Models. In: ADEA Newsletter 17(2): 11-12.

Hoogvelt, A. (1997): Globalisation and the Postcolonial World. Houndmills, London: Macmillan Press.

Ilon, L. (1994): Structural adjustment and education: Adapting to a growing global market. In: International Journal of Educational Development 14 (2): 95-108.

Jones, P. W. (2007): Education and world order. In: Comparative Education 43(3): 325-337.

Kogl, I./Kurze, K. (2013): Sustainable Development: A floating signifier in the EU's energy policy discourse. In: Barnes, P.M./Hoerber, T.C. (eds.): Sustainable Development and Governance in Europe: The evolution of the discourse on sustainability, Abingdon: Routledge, pp. 61-74.

Laclau, E. (2005): On Populist Reason. London: Verso.

Launey, R. (2016): Islamic Education in Africa: Writing Boards and Blackboards. Indiana: Indiana University Press.

Leach, F. (2004): School-based gender violence in Africa: A risk to adolescent sexual health. In: Coombe, C. (ed.): The HIV challenge to education: a collection of essays. Paris: UNESCO IIEP, pp. 221-246.

Lélé, S.M. (1991): Sustainable development: A critical review. In: World Development 19(6): 607-621.

Loomba, A. (2005): Colonialism/ Postcolonialism: the new critical idiom. Second edition ed. Abingdon: Routledge.

Lotz-Sisitka, H./Shumba, O./Lupele, J./Wilmot, D. (2017): Schooling for Sustainable Development in Africa. Switzerland: Springer.

Mamdani, M. (1996): Citizen and Subject: Contemporary Africa and the legacy of late colonialism. Princeton: Princeton University Press.

Mangan, J. (1988): Benefits Bestowed? Education and British Imperialism. Manchester: Manchester University Press.

Manji, F./O'Coill, C. (2002): The missionary position: NGOs and development in Africa. In: International Affairs 78(3): 567-583.

Mason, M. (2008): Complexity Theory and the Philosophy of Education. Chichester: John Wiley and Sons.

Mohan, G. (2013): Beyond the Enclave: Towards a Critical Political Economy of China in Africa. In: Development and Change 44(6): 1255-1272.

Moyo, S. (2015): The Land Question and Land Reform in Southern Africa. Harare: Sam Moyo African Institute for Agrarian Studies.

Mundy, K./Green, A./Lingard, R./Verger, A. (2017): The Handbook of Global Education Policy. New Jersey: Wiley Blackwell.

Nkrumah, K. (1966): Neo-colonialism: The Last Stage of Imperialism. London: Thomas Nelson and Sons. 
Novelli, M. (2010): The new geopolitics of educational aid: From Cold Wars to Holy Wars? In: International Journal of Educational Development 30(5): 453-459.

Nussbaum, M. (2006): The moral status of animals. In: The Chronicle of Higher Education 52(22): B6-B8.

Obi, C. (2005): Environmental Movements in Sub-Saharan Africa: A political ecology of power and conflict. Geneva: UNRISD.

Olmedo, A. (2014): From England with love...ARK, heterarchies and global 'philanthropic governance'. In: Journal of Education Policy 29(5): 575-597.

Olmedo, A. (2017): Something old, not much new, and a lot borrowed: philanthropy, business, and the changing roles of government in global education policy networks. In: Oxford Review of Education 43(1): 69-87.

Peck, J./Theodore, N. (2007): Variegated capitalism. In: Progress in Human Geography 31(6): 731-772.

Pinkney, R. (2009): NGOs, Africa and the Global Order. London: Palgrave Macmillan.

Pratt, L. (2011): Decreasing Dirty Dumping? A reevaluation of toxic waste colonialism and the global management of transboundary hazardous waste. Williamsburg: William and Mary Law School Scholarship Depository.

Ramalingam, B. (2013): Aid on the Edge of Chaos. Rethinking international cooperation in a complex world. Oxford: Oxford University Press.

Rist, G. (1997): The History of Development: from Western origins to global faith. London: Zed Books.

Robertson, S./Novelli, M./Dale, R./Tikly, L./Dachi, H.A./Alphonse, N. (2007): Globalisation, education and development: ideas, actors and dynamics. London: DFID.

Rodney, W. (1973): How Europe Underdeveloped Africa. London: BogleL'Ouverture Publications.

Rostow, W. (1960): The Stages of Economic Growth. Cambridge: Cambridge University Press.

Sachs, J. (2015): The Age of Sustainable Development. New York: Columbia University Press.

Samoff, J. (1994): Coping with crisis: austerity, adjustment and human resources. London: Cassell.

Schlosberg, D. (2007): Defining Environmental Justice: Theories, Movements and Nature. Oxford: Oxford University Press.

Schultz, T. (1961): Investment in Human Capital. In: The American Economic Review 51(1): 1-17.

Sen, A. (1999): Development as freedom. Oxford: Oxford University Press.

Sen, A. (2009): The Idea of Justice. London: Penguin.

Sen, A. (2013): The Ends and Means of Sustainability. In: Journal of Human Development and Capabilities 14(1): 6-20.

Shiva, V. (2000): The world on the Edge. In: Hutton, W./Giddens, A. (eds.): On the Edge. Living with Global Capitalism. London: Jonathan Cape, pp. 112-129. 
Sparr, P. (1994): Mortgaging Women's Lives: Feminist Critiques of Structural Adjustment. London: Zed books.

Tikly, L. (1994): Education Policy in South Africa Since 1947. Glasgow: University of Glasgow.

Tikly, L. (1999): Postcolonialism And Comparative Education. In: International Review of Education 45(5): 603-621.

Tikly, L. (2003): The African Renaissance, NEPAD and skills formation: An identification of key policy tensions. In: International Journal of Educational Development 23: 543-564.

Tikly, L. (2015): What works, for whom, and in what circumstances? Towards a critical realist understanding of learning in international and comparative education. In: International Journal of Educational Development 40: 237-249.

Tikly, L. (2017): The future of Education for All as a global regime of educational governance. In: Comparative Education Review 61(1): 22-57.

Tikly, L./Barrett, A. (2013): Education Quality and Social Justice in the Global South: Challenges for Policy, Practice and Research. Abingdon: Routledge.

Tikly, L./Joubert, M./Barrett, A.M./Bainton, D./Cameron, L./Doyle, H. (2018): Supporting Secondary School STEM Education for Sustainable Development in Africa. Bristol Working Papers in Education. Bristol: School of Education, University of Bristol.

Tikly, L./Lowe, J./Crossley, M./Dachi, H.A./Garrett, R./Mukabaranga, B. (2003): Globalisation and Skills for Development in Rwanda and Tanzania. London: DfID.

Trudell, B. (2009): Local community perspectives and language of education in subSaharan African communities. In: International Journal of Educational Development 27(5): 552-563.

UNESCO (2017): Global Education Monitoring Report: Accountability in Education: Meeting our commitments. Paris: UNESCO.

Verger, A./Altinyelken, H./Novelli, M. (2018): Global Education Policy and International Development. London: Bloomsbury.

Verger, A./Fontdevila, C./Zancajo, A. (2016): The Privatization of Education: A political economy of global education reform. New York: Teachers College Press.

Walby, S. (2009): Globalization and Inequalities: complexity and contested modernity. London: Sage.

Walby, S. (2015): Crisis. Cambridge: Polity Press.

Wals, A.E.J./Kieft, G. (2010): Education for Sustainable Development: Research Overview. Sida 2010:13. http://library.wur.nl/WebQuery/wurpubs/fulltext/161396 [Access: 2 May 2019].

WBG (2017): Africa Competitiveness Report 2017. Washington: World Bank Group. WCED (1987): Our Common Future. Oxford: Oxford University Press.

Wells, J. (2013): Complexity and Sustainability. London: Routledge. 
White, B. (1996): Talk About School: Education and the colonial project in French and British Africa (1860-1960). In: Comparative Education 32(1): 9-26.

Whitehead, C. (2003): Oversea Education and British colonial education 1929-63. In: History of Education 32(5): 561-575.

Williams, D./Young, T. (2009): The International Politics of Social Transformation Trusteeship and Intervention in Historical Perspective. In: Duffield, M./Hewitt, V. (eds.): Empire, Development and Colonialism: The past in the present. London: Boydell and Brewer, James Currey, pp. 102-115. 



\title{
3 Beiträge einer Bildung für nachhaltige Entwicklung zum Erreichen der Sustainable Development Goals - Perspektiven, Lernziele und Forschungsbedarfe
}

\author{
Marco Rieckmann
}

\subsection{Die Nachhaltigkeitsziele - eine ambitionierte und universelle Agenda für die Transformation der Weltgesellschaft}

Am 25. September 2015 verabschiedete die UN-Vollversammlung die Agenda 2030 für Nachhaltige Entwicklung (Vereinte Nationen 2015). Dieses neue globale Rahmenwerk zur nachhaltigen Entwicklung der Weltgesellschaft wurde im Anschluss an die UN-Konferenz über nachhaltige Entwicklung $($ Rio + 20) in Rio de Janeiro (Brasilien) im Juni 2012 in einem dreijährigen Prozess entwickelt, an dem neben den UN-Mitgliedstaaten, NGOs und anderen Akteuren auch Millionen von Menschen aus der ganzen Welt beteiligt waren (vgl. Kercher 2015; Scholz 2015, 2017). Im Mittelpunkt der Agenda 2030 stehen 17 Nachhaltigkeitsziele (Sustainable Development Goals, SDGs).

Die universellen, transformativen und inklusiven SDGs beschreiben wichtige Entwicklungsherausforderungen für die Menschheit. Das Ziel der 17 SDGs (siehe Kasten 1) ist es, für alle, jetzt und in Zukunft, ein nachhaltiges, friedliches, wohlhabendes und gerechtes Leben zu ermöglichen. Die SDGs beziehen sich auf globale Herausforderungen, die für das Überleben der Menschheit entscheidend sind. Sie setzen ökologische Grenzen fest und definieren kritische Schwellenwerte für den Einsatz natürlicher Ressourcen. Sie erkennen an, dass Armutsbekämpfung Hand in Hand gehen muss mit Strategien, die wirtschaftliche Entwicklung befördern. Sie widmen sich einer Reihe von sozialen Bedürfnissen, einschließlich Bildung, Gesundheit, sozialer Absicherung und Beschäftigungsmöglichkeiten, während sie gleichzeitig auf die Bewältigung des Klimawandels und Umweltschutz abzielen. Die SDGs adressieren die wichtigsten systemischen Barrieren für eine nachhalti- 
ge Entwicklung wie Ungleichheit, nicht-nachhaltige Konsummuster, schwache institutionelle Kapazitäten und Umweltzerstörung (vgl. Messner/Scholz 2015; Scholz 2015, 2017).

\section{Kasten 1: Die 17 Nachhaltigkeitsziele (SDGs) (BMZ 2019)}

1. Keine Armut - Armut in jeder Form und überall beenden

2. Keine Hungersnot - Den Hunger beenden, Ernährungssicherheit und eine bessere Ernährung erreichen und eine nachhaltige Landwirtschaft fördern

3. Gute Gesundheitsversorgung und Wohlergehen - Ein gesundes Leben für alle Menschen jeden Alters gewährleisten und ihr Wohlergehen fördern

4. Hochwertige Bildung - Inklusive, gerechte und hochwertige Bildung gewährleisten und Möglichkeiten des lebenslangen Lernens für alle fördern

5. Gleichberechtigung der Geschlechter - Geschlechtergerechtigkeit und Selbstbestimmung für alle Frauen und Mädchen erreichen

6. Sauberes Wasser und sanitäre Einrichtungen - Verfügbarkeit und nachhaltige Bewirtschaftung von Wasser und Sanitärversorgung für alle gewährleisten

7. Erschwingliche und saubere Energie - Zugang zu bezahlbarer, verlässlicher, nachhaltiger und zeitgemäßer Energie für alle sichern

8. Gute Arbeitsplätze und wirtschaftliches Wachstum - Dauerhaftes, inklusives und nachhaltiges Wirtschaftswachstum, produktive Vollbeschäftigung und menschenwürdige Arbeit für alle fördern

9. Industrie, Innovation und Infrastruktur - Eine belastbare Infrastruktur aufbauen, inklusive und nachhaltige Industrialisierung fördern und Innovationen unterstützen

10. Reduzierte Ungleichheiten - Ungleichheit innerhalb von und zwischen Staaten verringern

11. Nachhaltige Städte und Gemeinden - Städte und Siedlungen inklusiv, sicher, widerstandsfähig und nachhaltig machen

12. Verantwortungsvoller Konsum und Produktion - Für nachhaltige Konsum- und Produktionsmuster sorgen

13. Klimaschutz - Umgehend Maßnahmen zur Bekämpfung des Klimawandels und seiner Auswirkungen ergreifen

14. Leben im Wasser - Ozeane, Meere und Meeresressourcen im Sinne einer nachhaltigen Entwicklung erhalten und nachhaltig nutzen

15. Leben an Land - Landökosysteme schützen, wiederherstellen und ihre nachhaltige Nutzung fördern, Wälder nachhaltig bewirtschaften, Wüstenbildung bekämpfen, Bodenverschlechterung stoppen und umkehren und den Biodiversitätsverlust stoppen

16. Frieden, Gerechtigkeit und starke Institutionen - Friedliche und inklusive Gesellschaften im Sinne einer nachhaltigen Entwicklung fördern, allen Menschen Zugang zur Justiz ermöglichen und effektive, rechenschaftspflichtige und inklusive Institutionen auf allen Ebenen aufbauen

17. Partnerschaften für die Ziele - Umsetzungsmittel stärken und die globale Partnerschaft für nachhaltige Entwicklung wiederbeleben

Damit die Ziele erreicht werden können, müssen viele ihren Beitrag leisten: Regierungen, die Privatwirtschaft, die Zivilgesellschaft und alle Menschen auf der ganzen Welt. Es wird von den Regierungen erwartet, dass sie sich die 
Ziele zu eigen machen und nationale Rahmenbedingungen sowie politische Strategien und Maßnahmen zur Umsetzung der Agenda 2030 schaffen.

Ein wesentliches Merkmal der Agenda 2030 für Nachhaltige Entwicklung ist ihre Universalität und Unteilbarkeit. Sie richtet sich an alle Länder - aus dem Globalen Süden und dem Globalen Norden. Alle Länder, die sich der Agenda 2030 verschreiben, müssen ihre eigenen Entwicklungsbemühungen an dem Ziel ausrichten, den Wohlstand zu fördern und gleichzeitig den Planeten zu schützen, um eine nachhaltige Entwicklung zu erreichen (vgl. Messner/Scholz 2015). Insofern können in Bezug auf die SDGs alle Länder als Entwicklungsländer betrachtet werden, und alle Länder müssen dringend Maßnahmen zur Förderung einer nachhaltigen Entwicklung ergreifen.

\subsection{Bildung für nachhaltige Entwicklung - ein Schlüsselinstrument zum Erreichen der Nachhaltigkeitsziele}

"Education can, and must, contribute to a new vision of sustainable global development." (UNESCO 2015b, S. 32)

Den Weg einer nachhaltigen Entwicklung einzuschlagen, wird eine tiefgreifende Transformation unserer Art zu Denken und zu Handeln erfordern. Um eine nachhaltigere Welt zu schaffen und mit nachhaltigkeitsrelevanten Problemstellungen umzugehen, wie sie in den SDGs beschrieben werden, müssen Individuen Change Agents für eine nachhaltige Entwicklung werden. Sie benötigen das Wissen, die Fähigkeiten, die Werte und die Einstellungen, die sie dazu in die Lage versetzen, zu einer nachhaltigen Entwicklung beizutragen.

Bildung ist daher entscheidend für das Erreichen einer nachhaltigen Entwicklung. Doch nicht jede Art von Bildung unterstützt eine nachhaltige Entwicklung. Bildung, die das Wirtschaftswachstum allein fördert, kann auch zu einer Zunahme nicht-nachhaltiger Konsummuster führen. Das mittlerweile gut etablierte Konzept einer Bildung für nachhaltige Entwicklung (BNE) ermächtigt die Lernenden, fundierte Entscheidungen für den Erhalt der Umwelt, wirtschaftliche Leistungsfähigkeit und eine gerechte Gesellschaft für gegenwärtige und zukünftige Generationen zu treffen und entsprechend verantwortungsbewusst zu handeln (vgl. Rieckmann 2016). BNE zielt darauf ab, Kompetenzen zu entwickeln, die es den Individuen ermöglichen, über ihre eigenen Handlungen unter Berücksichtigung ihrer gegenwärtigen und zukünftigen sozialen, kulturellen, wirtschaftlichen und ökologischen Auswirkungen - unter lokaler und globaler Perspektive - nachzudenken, in komplexen Situationen nachhaltig zu handeln, was von dem Individuum erfordern 
kann, neue Richtungen einzuschlagen, und sich an gesellschaftspolitischen Prozessen zu beteiligen, die ihre Gesellschaften in Richtung einer nachhaltigen Entwicklung bewegen (vgl. de Haan 2010; de Haan et al. 2008; Overwien 2013; Rieckmann 2013, 2016, 2018).

BNE muss als integraler Bestandteil von hochwertiger Bildung verstanden werden, die ein Element des Konzepts des lebenslangen Lernens ist: Alle Bildungseinrichtungen - vom Vorschul- bis zum Hochschulbereich bis hin zur non-formalen und informellen Bildung - können und sollten es als ihre Verantwortung betrachten, sich intensiv mit Fragen einer nachhaltigen Entwicklung $\mathrm{zu}$ beschäftigen und die Entwicklung von Nachhaltigkeitskompetenzen zu fördern (vgl. Nationale Plattform Bildung für nachhaltige Entwicklung 2017; Rieckmann 2016). BNE ermöglicht Bildungs- und Lernprozesse, die für jeden Lernenden angesichts der heutigen Herausforderungen sehr relevant sind.

Die internationale Anerkennung von BNE als wichtiges Instrument für die Förderung einer nachhaltigen Entwicklung ist stetig gewachsen. Diese Bedeutung von BNE wurde auch auf den drei wichtigsten globalen Gipfeltreffen für nachhaltige Entwicklung betont: die UN-Konferenz über Umwelt und Entwicklung (UNCED) 1992 in Rio de Janeiro; der Weltgipfel für Nachhaltige Entwicklung (WSSD) 2002 in Johannesburg, und die UN-Konferenz für Nachhaltige Entwicklung (UNCSD) 2012 ebenfalls in Rio de Janeiro.

Die UN-Dekade Bildung für nachhaltige Entwicklung (2005-2014) zielte darauf ab, die Prinzipien und Praktiken einer nachhaltigen Entwicklung umfassend in Bildungs- und Lernprozesse zu integrieren, um Veränderungen von Wissen, Werten und Einstellungen im Sinne der Vision einer nachhaltigeren und gerechteren Gesellschaft für alle zu fördern. Das Weltaktionsprogramm (WAP) Bildung für nachhaltige Entwicklung, das am 12. November 2014 auf der UNESCO-Weltkonferenz zu BNE (Aichi-Nagoya, Japan) lanciert wurde, strebt danach, auf der Grundlage der Ergebnisse der Dekade die Umsetzung von BNE zu intensivieren (UNESCO 2014).

BNE wird in den SDGs ausdrücklich als Teil des Ziels 4.7 des SDG zu hochwertiger Bildung anerkannt (siehe Kasten 2) - zusammen mit Global Citizenship Education (GCED), die die UNESCO als einen komplementären Ansatz fördert (UNESCO 2015a).

Kasten 2: Ziel 4.7 der SDGs (Vereinte Nationen 2015, S. 19)

Bis 2030 sicherstellen, dass alle Lernenden die notwendigen Kenntnisse und Qualifikationen zur Förderung nachhaltiger Entwicklung erwerben, unter anderem durch Bildung für nachhaltige Entwicklung und nachhaltige Lebensweisen, Menschenrechte, Geschlechtergleichstellung, eine Kultur des Friedens und der Gewaltlosigkeit, Weltbürgerschaft und die Wertschätzung kultureller Vielfalt und des Beitrags der Kultur zu nachhaltiger Entwicklung 
Gleichzeitig ist es wichtig, die zentrale Bedeutung von BNE für alle anderen 16 SDGs zu betonen. Diese hebt auch der UNESCO-Bericht „Rethinking Education“ (UNESCO 2015b) hervor:

„Education is key to the global integrated framework of sustainable development goals. Education is at the heart of our efforts both to adapt to change and to transform the world within which we live." (ebd., S. 5)

Mit ihrem Ziel, übergreifende Nachhaltigkeitskompetenzen bei den Lernenden zu entwickeln, leistet BNE einen wesentlichen Beitrag für alle Bemühungen zum Erreichen der SDGs. Denn BNE befähigt Individuen, an einer nachhaltigen Entwicklung mitzuwirken, indem sie den gesellschaftlichen, wirtschaftlichen und politischen Wandel fördern und ihr eigenes Verhalten ändern (UNESCO 2017).

Zudem kann BNE spezifische kognitive, sozioemotionale und verhaltensbezogene Lernergebnisse erzielen, die es Individuen ermöglichen, mit den besonderen Herausforderungen jedes SDG umzugehen und so dessen Umsetzung zu unterstützen. BNE ermöglicht es allen Individuen, zur Erreichung der SDGs beizutragen, indem sie mit den notwendigen Kenntnissen und Kompetenzen ausgestattet werden, die sie nicht nur brauchen, um zu verstehen, worum es bei den SDGs geht, sondern auch um sich als informierte Bürgerinnen und Bürger für die Herbeiführung der notwendigen Transformation einzusetzen (UNESCO 2017).

Eine aktuelle Studie von Müller-Christ et al. (2018) zeigt, dass die SDGs im deutschen Bildungssystem bereits aufgegriffen werden.

„Es bleibt aber noch eine Menge zu tun, bis die SDGs ein selbstverständliches Thema im deutschen Bildungssystem sind. Besonders in den Bereichen der beruflichen Bildung, des non-formalen und informellen Lernens, sowie im Bereich der Fort- und Weiterbildung ist noch viel Überzeugungs- und Kommunikationsarbeit nötig“ (ebd., S. 25).

\subsection{Lernziele zum Erreichen der SDGs}

BNE kann übergreifende Nachhaltigkeitskompetenzen entwickeln, die für alle SDGs relevant sind. Zudem kann BNE auch spezifische Lernergebnisse erzielen, die Individuen benötigen, um zum Erreichen eines bestimmten SDGs beitragen zu können.

\subsubsection{Schlüsselkompetenzen für das Erreichen der SDGs}

Die Weltgesellschaft steht vor diversen Herausforderungen: eine zunehmende Komplexität und Unsicherheit, mehr Individualisierung und soziale Vielfalt, 
wachsende wirtschaftliche und kulturelle Einheitlichkeit, eine Verschlechterung der Ökosystemdienstleistungen und eine zunehmende Anfälligkeit und Exposition gegenüber natürlichen und technologischen Gefahren. Vor diesem Hintergrund müssen die Menschen lernen, die komplexe Welt zu verstehen, in der sie leben. Sie müssen in der Lage sein, zusammenzuarbeiten, ihre Meinung zu äußern und sich für positive Veränderungen einzusetzen (vgl. UNESCO 2015b). Es geht darum, „Nachhaltigkeitsbürger*innen“ (Rieckmann/ Schank 2016; Wals 2015; Wals/Lenglet 2016) zu werden.

Kasten 3: Nachhaltigkeitskompetenzen (UNESCO 2017)

- Kompetenz zum Vernetzen Denken: die Fähigkeiten, Zusammenhänge zu erkennen und zu verstehen; komplexe Systeme zu analysieren; zu überlegen, wie Systeme in verschiedene Domänen und verschiedene Skalen eingebettet sind; und mit Unsicherheit umzugehen

- Kompetenz zum Vorausschauenden Denken: die Fähigkeiten, multiple (mögliche, wahrscheinliche und wünschenswerte) Zukünfte zu verstehen und zu bewerten; eigene Visionen für die Zukunft zu schaffen; das Vorsorgeprinzip anzuwenden; die Konsequenzen von Handlungen zu beurteilen; und mit Risiken und Veränderungen umzugehen

- $\quad$ Normative Kompetenz: die Fähigkeiten, die Normen und Werte zu verstehen und zu reflektieren, die den eigenen Handlungen zugrunde liegen; und Nachhaltigkeitswerte, Prinzipien und Ziele im Kontext von Interessenkonflikten und TradeOffs, unsicheren Kenntnissen und Widersprüchen zu verhandeln

- Strategische Kompetenz: die Fähigkeiten zur kollektiven Entwicklung und Umsetzung innovativer Maßnahmen, die Nachhaltigkeit auf lokaler Ebene und darüber hinaus voran bringen

- Kooperationskompetenz: die Fähigkeiten, von anderen zu lernen; die Bedürfnisse, Perspektiven und Handlungen anderer zu verstehen und zu respektieren (Empathie), andere zu verstehen, eine Beziehung zu innen aufzubauen und für sie empfindsam zu sein (empathische Führung); mit Konflikten in einer Gruppe umzugehen; und eine kollaborative und partizipative Problemlösung zu ermöglichen

- Kompetenz zum Kritischen Denken: die Fähigkeit, Normen, Praktiken und Meinungen zu hinterfragen; die eigenen Werte, Wahrnehmungen und Handlungen zu reflektieren; und sich im Nachhaltigkeitsdiskurs zu positionieren

- Selbstkompetenz: die Fähigkeit, über die eigene Rolle in der lokalen Gemeinschaft und (globalen) Gesellschaft nachzudenken; kontinuierlich seine Handlungen zu bewerten und sich weiter zu motivieren; und sich mit den eigenen Gefühlen und Wünschen auseinanderzusetzen

- Integrierte Problemlösekompetenz: die übergreifende Fähigkeit, unterschiedliche Problemlösungsrahmen für komplexe Nachhaltigkeitsprobleme anzuwenden und passfähige, inklusive und gerechte Lösungsmöglichkeiten zu entwickeln, die eine nachhaltige Entwicklung fördern und die oben genannten Kompetenzen integrieren

Nachhaltigkeitsbürger*innen benötigen bestimmte Schlüsselkompetenzen (vgl. Rychen 2003; Weinert 2001), die es ihnen ermöglichen, konstruktiv und verantwortungsvoll mit der heutigen Welt umzugehen. Einige Schlüsselkom- 
petenzen werden im internationalen BNE-Diskurs als besonders wichtig für eine nachhaltige Entwicklung angesehen (siehe Kasten 3) (vgl. de Haan 2010; de Haan et al. 2008; Rieckmann 2012, 2013, 2018; Wiek et al. 2011, 2016).

Diese Nachhaltigkeitskompetenzen machen deutlich, wozu Nachhaltigkeitsbürger*innen insbesondere in der Lage sein sollten, um sich mit den heutigen komplexen Herausforderungen auseinandersetzen zu können. Sie sind für alle SDGs relevant und ermöglichen es den Individuen, die verschiedenen SDGs in Beziehung zueinander zu setzen, um das große Ganze der Agenda 2030 für Nachhaltige Entwicklung zu erkennen (UNESCO 2017).

\subsubsection{Spezifische Lernziele für die SDGs}

Während die Nachhaltigkeitskompetenzen dazu befähigen, insgesamt mit den SDGs umzugehen, lässt sich für jedes einzelne SDG die Frage stellen, wie damit verbundene, spezifische Lernprozesse gestaltet werden können.

Dazu bietet der von der UNESCO (2017) veröffentliche Leitfaden „Education for Sustainable Development Goals. Learning Objectives" vielfältige Anregungen. Dieses Dokument zielt darauf ab, politische Entscheidungsträger*innen, Curriculum-Entwickler*innen und Lehrende bei der Gestaltung von Strategien, Lehrplänen und Bildungsveranstaltungen zu unterstützen, um Lernen für die SDGs zu fördern. Im Sinne einer allgemeinen Orientierung sind die Lernziele, Themen und Aktivitäten für jedes SDG nicht für spezifische Altersgruppen, Lernumgebungen oder bestimmte soziokulturelle Kontexte zugeschnitten. Sie sind so konzipiert, dass sie für alle Lernenden aller Altersgruppen weltweit relevant sind und ihre Anwendung in allen möglichen Lernumgebungen finden können. Es handelt sich also um Vorschläge für Lernziele und -inhalte, die Pädagoginnen und Pädagogen auswählen und an ihre konkreten Lehr-Lern-Kontexte (soziokulturelle Anforderungen, Zielgruppen, etc.) anpassen können.

Es werden für jedes SDG Lernziele in einer kognitiven, sozioemotionalen und verhaltensbezogenen Domäne beschrieben (UNESCO 2017):

- Die kognitive Domäne umfasst Wissen und kognitive Fähigkeiten, die notwendig sind, um das SDG und die mit seinem Erreichen verbundenen Herausforderungen besser zu verstehen.

- Die sozio-emotionale Domäne umfasst soziale Kompetenzen, die es Lernenden ermöglichen, zusammenzuarbeiten, zu verhandeln und zu kommunizieren, um das SDG voranzubringen, sowie Selbstreflexionsfähigkeiten, Werte, Einstellungen und Motivationen, die es den Lernenden ermöglichen, sich selbst weiterzuentwickeln.

- Die verhaltensbezogene Domäne beschreibt Handlungskompetenzen. 
Zur Verdeutlichung dieses Ansatzes werden hier exemplarisch die Lernziele zum SDG 1 „Keine Armut“ dargestellt (siehe Tab. 1).

\section{Tabelle 1: Lernziele für das SDG 1 „Keine Armut“ (UNESCO 2017, S. 12)}

\begin{tabular}{|c|c|}
\hline $\begin{array}{l}\text { Cognitive learning ob- } \\
\text { jectives }\end{array}$ & $\begin{array}{l}\text { 1. The learner understands the concepts of extreme and } \\
\text { relative poverty and is able to critically reflect on their under- } \\
\text { lying cultural and normative assumptions and practices. } \\
2 \text {. The learner knows about the local, national and global } \\
\text { distribution of extreme poverty and extreme wealth. } \\
\text { 3. The learner knows about causes and impacts of poverty } \\
\text { such as unequal distribution of resources and power, coloni- } \\
\text { zation, conflicts, disasters caused by natural hazards and } \\
\text { other climate change-induced impacts, environmental degra- } \\
\text { dation and technological disasters, and the lack of social } \\
\text { protection systems and measures. } \\
4 \text {. The learner understands how extremes of poverty and } \\
\text { extremes of wealth affect basic human rights and needs. } \\
5 \text {. The learner knows about poverty reduction strategies and } \\
\text { measures and is able to distinguish between deficit-based } \\
\text { and strength-based approaches to addressing poverty. }\end{array}$ \\
\hline $\begin{array}{l}\text { Socio-emotional learn- } \\
\text { ing objectives }\end{array}$ & $\begin{array}{l}\text { 1. The learner is able to collaborate with others to empower } \\
\text { individuals and communities to affect change in the distribu- } \\
\text { tion of power and resources in the community and beyond. } \\
2 \text {. The learner is able to raise awareness about extremes of } \\
\text { poverty and wealth and encourage dialogue about solutions. } \\
\text { 3. The learner is able to show sensitivity to the issues of } \\
\text { poverty as well as empathy and solidarity with poor people } \\
\text { and those in vulnerable situations. } \\
\text { 4. The learner is able to identify their personal experiences } \\
\text { and biases with respect to poverty. } \\
5 \text {. The learner is able to critically reflect on their own role in } \\
\text { maintaining global structures of inequality. }\end{array}$ \\
\hline $\begin{array}{l}\text { Behavioural learning } \\
\text { objectives }\end{array}$ & $\begin{array}{l}\text { 1. The learner is able to plan, implement, evaluate and repli- } \\
\text { cate activities that contribute to poverty reduction. } \\
\text { 2. The learner is able to publicly demand and support the } \\
\text { development and integration of policies that promote social } \\
\text { and economic justice, risk reduction strategies as well as } \\
\text { poverty eradication actions. } \\
\text { 3. The learner is able to evaluate, participate in and influence } \\
\text { decision-making related to management strategies of local, } \\
\text { national and international enterprises concerning poverty } \\
\text { generation and eradication. } \\
4 \text {. The learner is able to include poverty reduction, social } \\
\text { justice and anti-corruption considerations in their consump- } \\
\text { tion activities. } \\
5 \text {. The learner is able to propose solutions to address sys- } \\
\text { temic problems related to poverty. }\end{array}$ \\
\hline
\end{tabular}


Um dieses Wissen und die genannten Fähigkeiten bei den Lernenden zu entwickeln, bieten sich einige Inhalte besonders an (siehe Kasten 4). Dabei handelt es sich nicht um eine erschöpfende Auflistung, sondern um Vorschläge von weltweit relevanten Aspekten des jeweiligen SDG. Diese sollten durch lokal relevante Themen ergänzt, und mit neuen Themen aktualisiert werden, die sich ständig in unserer sich schnell verändernden Welt ergeben.

Kasten 4: Vorschläge für Themen zur Bearbeitung des SDG 1 „Keine Armut" (UNESCO 2017, S. 13)

1. Definitions of poverty

2. Global, national and local distribution of extreme poverty and extreme wealth and their reasons

3. The importance of social welfare protection systems and measures

4. The importance of equal rights to economic resources, as well as access to basic services, ownership and control over land and other forms of property, inheritance, natural resources, appropriate new technology and financial services, including microfinance

5. The interrelation of poverty, natural hazards, climate change, and other economic, social and environmental shocks and stresses

6. Work conditions related to poverty such as sweatshops, child labour and modern slavery

7. Resilience of the poor and those in vulnerable situations

8. Consequences of poverty such as malnutrition, child and maternal mortality, crime and violence

9. Development cooperation

10. Policy frameworks at the local, national and international levels, based on pro-poor and gender-sensitive development strategies

Ebenso werden einige Methoden vorgestellt, die zur Bearbeitung der Themen und der Entwicklung der jeweiligen Lernziele geeignet sind (siehe Kasten 5).

Kasten 5: Beispielhafte Lernansätze und -methoden für das SDG 1 „Keine Armut" (UNESCO 2017, S. 13)

1. Develop partnerships between schools and universities in different regions of the world (South and North; South and South).

2. Plan and run an awareness campaign about poverty locally and globally.

3. Plan and run a student company selling fair trade products.

4. Plan and implement local service-learning and/or engagement opportunities for empowering poor people, reducing their vulnerability to different hazards and increasing their resilience - in collaboration with NGOs, the private sector and/or community groups, etc.

5. Conduct a case study on poverty and wealth in selected countries (through desktop research) or at the local level (through excursions, doing interviews, etc.).

6. Provide internships within organisations addressing poverty.

7. Develop an enquiry-based project around: "Is poverty increasing or decreasing?" 
Die für jedes SDG beschriebenen spezifischen Lernziele sind immer in Verbindung mit den übergreifenden Nachhaltigkeitskompetenzen zu sehen. Denn erst die Schlüsselkompetenzen ermöglichen es den Lernenden, die komplexen Zusammenhänge und auch Widersprüche zwischen den 17 SDGs zu erkennen und zu verstehen.

\subsection{Handlungsorientierte, transformative Pädagogik}

Für die Entwicklung der Nachhaltigkeitskompetenzen und das Erreichen der Lernziele für die einzelnen SDGs bedarf es einer handlungsorientierten, transformativen Pädagogik, die sich durch Aspekte wie selbstgesteuertes Lernen, Partizipation und Kooperation, Problemorientierung, Inter- und Transdisziplinarität und die Verknüpfung von formalem und informellem Lernen auszeichnet (UNESCO 2017). Nur solche pädagogischen Ansätze ermöglichen den Erwerb derjenigen Schlüsselkompetenzen, die für die Förderung einer nachhaltigen Entwicklung erforderlich sind (vgl. Rieckmann 2016, 2018).

Einer Bildung für nachhaltige Entwicklung geht es darum, die Lernenden zu befähigen und zu motivieren, aktive Nachhaltigkeitsbürger*innen zu werden, die in der Lage sind, kritisch zu denken und sich an der Gestaltung einer nachhaltigen Zukunft zu beteiligen. Pädagogische Ansätze, die diesem Ziel entsprechen, sind lernerzentriert, handlungsorientiert und transformativ (siehe Kasten 6).

Kasten 6: Zentrale pädagogische Ansätze einer BNE (UNESCO 2017)

\section{Ein lernerzentrierter Ansatz}

Die lernerzentrierte Pädagogik geht von selbstständigen Lernenden aus und betont die aktive Entwicklung des Wissens anstatt dem bloßen Wissenstransfer und/oder passiven Lernerfahrungen. Das Vorwissen der Lernenden sowie ihre Erfahrungen im sozialen Kontext sind die Ausgangspunkte für die Förderung von Lernprozessen, in denen die Lernenden ihre eigene Wissensbasis konstruieren. Lernerzentrierte Ansätze erfordern von den Lernenden, über ihre eigenen Kenntnisse und Lernprozesse nachzudenken, um sie zu steuern und zu verfolgen. Lehrende sollten diese Reflexionen anregen und unterstützen. Lernerzentrierte Ansätze verändern die Rolle des Lehrenden zu einer als Moderator*in von Lernprozessen (Barth 2015).

\section{Handlungsorientiertes Lernen}

Im handlungsorientierten Lernen werden die Lernenden selbst tätig und reflektieren ihre Erfahrungen in Bezug auf den beabsichtigten Lernprozess und die angestrebte persönliche Entwicklung. Die Erfahrung könnte sich aus einem Projekt, einem Praktikum, die Durchführung eines Workshops, die Durchführung einer Kampagne, etc. ergeben. Handlungsorientiertes Lernen bezieht sich auf Kolbs Theorie des erfahrungsbasierten Lernzyklus mit den folgenden Phasen: 1. Ein konkretes Erlebnis haben, 2. Beobachten 
und reflektieren, 3. Abstrakte Konzepte zur Verallgemeinerung entwickeln, 4. Sie in neuen Situationen anwenden (Kolb 1984). Handlungsorientiertes Lernen steigert den Wissenserwerb, die Kompetenzentwicklung und die Klärung von Werten durch die Verknüpfung von abstrakten Konzepten mit persönlicher Erfahrung und dem Leben des Lernenden. Die Rolle des Lehrenden besteht darin, eine Lernumgebung zu schaffen, die die Erfahrungen der Lernenden und reflexive Denkprozesse anregt.

\section{Transformatives Lernen}

Das transformative Lernen zielt darauf ab, die Lernenden dazu zu befähigen, die Art und Weise zu hinterfragen und zu verändern, wie sie die Welt sehen und über sie denken, um ihr Verständnis von ihr zu erweitern (Slavich/Zimbardo 2012; Mezirow 2000). Der Lehrende ist ein Facilitator, der die Lernenden befähigt und herausfordert, ihre Weltanschauungen zu verändern. Das verwandte Konzept des transgressiven Lernens (Lotz-Sisitka et al. 2015) geht noch einen Schritt weiter: Es betont, dass das Lernen in der BNE den Status quo überwinden und die Lernenden für disruptives (störendes) Denken und die Co-Kreation neuen Wissens vorbereiten sollte.

Diese pädagogischen Ansätze stellen allgemeine Prinzipien für die Gestaltung von Lernprozessen in der BNE dar. Spezifische Methoden, die diesen Prinzipien entsprechen, sind erforderlich, um den Lernprozess zu ermöglichen. In der BNE werden Methoden bevorzugt, die die Entwicklung von Kompetenzen durch aktives Lernen fördern. Bestimmte Methoden können für BNE besonders empfohlen werden (siehe Kasten 7). Diese partizipativen Lehr- und Lernmethoden befähigen die Lernenden, sich an der Gestaltung einer nachhaltigen Entwicklung zu beteiligen.

Kasten 7: Schlüsselmethoden für das Lernen für die SDGs (UNESCO 2017)

- Kollaborative Projekte in Ernstsituationen wie Service-Learning-Projekte und Kampagnen für verschiedene SDGs

- Methoden zur Entwicklung von Zukunftsentwürfen wie Zukunftswerkstätten, Szenarioanalysen, utopische/dystopische Erzählungen, Science-Fiction-Denken sowie Prognosen und Backcasting

- Analysen komplexer Systeme durch partizipative Forschungsprojekte, Fallstudien, Stakeholder-Analysen, Akteursanalysen, Modellierung, Systemspiele, etc.

- Kritisches und reflektierendes Denken durch Fisch-Bowl-Diskussionen, Lerntagebücher, etc.

Um vielfältige und grenzüberschreitende Lernumgebungen zu schaffen und umfassende Bilder der SDGs zu entwickeln, sollten Bildungseinrichtungen und Lehrende Partnerschaften auf lokaler, nationaler und internationaler Ebene fördern (UNESCO 2017). Es ist wichtig zu erkennen, dass angemessene Reaktionen auf Nachhaltigkeitsprobleme nicht auf einzelne Perspektiven, Disziplinen oder Arten des Wissens beschränkt werden können. Partnerschaften, die eine Reihe von gesellschaftlichen Akteuren wie Unternehmen, NGOs, öffentliche Institutionen, politische Entscheidungsträger und/oder Einzelpersonen einbeziehen, eröffnen neue Lernmöglichkeiten. In einem 
Dialog oder einem Projekt, das die Zusammenarbeit mit einem Praxispartner beinhaltet, können die Lernenden etwas über realweltliche Herausforderungen erfahren und von den Kompetenzen und Erfahrungen der Partner profitieren (vgl. Barth et al. 2014). Partnerschaften zwischen Lernenden aus der ganzen Welt fördern den Austausch unterschiedlicher Perspektiven und Kenntnisse zu demselben Thema. Zum Beispiel können virtuelle Lehrveranstaltungen eine Umgebung schaffen, um einen globalen Dialog zu üben und gegenseitigen Respekt und Verständnis zu fördern (vgl. Barth/Rieckmann 2009).

\subsection{Forschungsbedarfe}

Weltweit lassen sich bereits Forschungsaktivitäten mit Bezug auf die SDGs ausmachen. Dabei bildet Forschung zum Bildungs-SDGs (SDG 4) durchaus einen Schwerpunkt (Lange Salvia et al. 2019). Adick (2018) konstatiert eine generelle Anschlussfähigkeit des SDG 4-Monitoring an Forschung im Rahmen einer internationalen Bildungsforschung: „Auf die zum SDG 4 aufbereiteten UIS-Daten ${ }^{1}$ kann und wird vermutlich in Zukunft in kleinen oder größeren Forschungsarbeiten zurückgegriffen werden“ (ebd., S. 17).

Aus der Perspektive einer BNE bestehen u.a. folgende Forschungsbedarfe im Kontext der SDGs:

- Analyse des Beitrags von BNE zu hochwertiger Bildung;

- Analyse des Beitrags von BNE zu inklusiver und gerechter Bildung;

- Intensivierung (up-scaling) von BNE: BNE-Implementierung und Governance-Prozesse;

- Vergleichende Forschung zu BNE im Globalen Süden und dem Globalen Norden;

- Operationalisierung von Nachhaltigkeitskompetenzen und Messung ihrer Entwicklung;

- Operationalisierung von kognitiven, sozio-emotionalen und verhaltensbezogenen Lernergebnissen (und deren Messung);

- Analyse von Curricula und pädagogischen Ansätzen hinsichtlich ihrer Beiträge zur Entwicklung von Nachhaltigkeitskompetenzen und spezifischen Lernzielen;

- Operationalisierung und Analyse der Kompetenzen von Lehrenden. goal-4. 


\subsection{Fazit}

Für das Erreichen der SDGs kommt BNE eine wichtige Bedeutung zu. Sie kann die Entwicklung von Nachhaltigkeitskompetenzen fördern, die Individuen nicht nur dazu befähigen, die SDGs in ihrer ganzen Komplexität zu verstehen, sondern auch eigene Beiträge zum Erreichen der Ziele zu leisten. Gleichzeitig kann BNE auch spezifische Lernprozesse ermöglichen, die dazu benötigt werden, sich ein bestimmtes SDG zu erschließen und eigene Beiträge zu diesem Ziel zu leisten. Zudem bieten die SDGs eine inhaltliche Orientierung für BNE. Sie zeigen wesentliche Themenstellungen auf, die es im Rahmen einer BNE zu bearbeiten gilt. Für die Entwicklung der Nachhaltigkeitskompetenzen und eine Auseinandersetzung mit den einzelnen SDGs bedarf es einer handlungsorientierten, transformativen Pädagogik.

Jedoch sollte BNE auch Räume für eine kritische Reflexion über die SDGs eröffnen. So kann es z.B. darum gehen, mit Lernenden die den SDGs inhärenten Widersprüche (u.a. in Bezug auf Wirtschaftswachstum, vgl. Messner/Scholz 2015) bzw. Leerstellen (u.a. „Dekarbonisierung“, „planetare Grenzen“, „Benennung und Bearbeitung von Ursachen hinter den zu lösenden Problemlagen“, Messner/Scholz 2015, S. 23; vgl. Scholz 2017) zu analysieren und zu diskutieren. Eine nachhaltige Entwicklung selbst ist ein Lernprozess, und Bildung für nachhaltige Entwicklung - verstanden als emanzipatorisches Bildungskonzept - sollte dazu beitragen, die Ziele und Grundlagen einer nachhaltigen Entwicklung immer wieder zu hinterfragen und weiterzuentwickeln.

Um mit BNE zur Förderung der SDGs beizutragen und sie aber auch kritisch zu reflektieren, ist es allerdings notwendig, dass BNE als Querschnittsanliegen in alle Bildungsbereiche integriert wird. Dieser Anspruch wird im Nationalen Aktionsplan Bildung für nachhaltige Entwicklung (Nationale Plattform Bildung für nachhaltige Entwicklung 2017) formuliert, und es sind in den letzten Jahren Entwicklungen in diese Richtung zu verzeichnen gewesen. Weiterhin stellt es aber eine große Herausforderung dar, BNE als orientierendes Bildungskonzept in den Strukturen und der Praxis des Bildungssystems zu verankern.

Dieser Prozess sollte wissenschaftlich begleitet werden. Somit ergeben sich im Kontext der SDGs und der weiteren Verankerung von BNE im Bildungssystem vielfältige Fragestellungen für die (internationale) Bildungsforschung. 


\section{Literatur}

Adick, C. (2018): Die Bildungsagenda der Vereinten Nationen aus dem Blickwinkel der internationalen Bildungsforschung. In: ZEP - Zeitschrift für internationale Bildungsforschung und Entwicklungspädagogik 41(2): 11-18.

Barth, M. (2015): Implementing sustainability in higher education: learning in an age of transformation. London: Routledge.

Barth, M./Adomßent, M./Fischer, D./Richter, S./Rieckmann, M. (2014): Learning to change universities from within: a service-learning perspective on promoting sustainable consumption in higher education. In: Journal of Cleaner Production 62: $72-81$.

Barth, M./Rieckmann, M. (2009): Experiencing the Global Dimension of Sustainability: Student Dialogue in a European-Latin American Virtual Seminar. In: International Journal of Development Education and Global Learning 1(3): 23-38.

BMZ (Bundesministerium für wirtschaftliche Zusammenarbeit und Entwicklung) (2019): Agenda 2030. 17 Ziele für nachhaltige Entwicklung. http://www.bmz.de/de/ministerium/ziele/2030_agenda/17_ziele/index.html [Zugriff: 03.05.2019].

de Haan, G. (2010): The development of ESD-related competencies in supportive institutional frameworks. In: International Review of Education 56(2): 315-328.

de Haan, G./Kamp, G./Lerch, A./Martignon, L./Müller-Christ, G./Nutzinger, H.-G. (Hrsg.) (2008): Nachhaltigkeit und Gerechtigkeit. Grundlagen und schulpraktische Konsequenzen. Berlin, Heidelberg: Springer.

Kercher, J. (2015): Wie die Nachhaltigkeitsziele in die Welt kamen. Von den MDGs zu den SDGs. In: oekom e.V. - Verein für ökologische Kommunikation (Hrsg.): Nachhaltige Entwicklungsziele. Agenda für eine bessere Welt? (Politische Ökologie, 143). München: Oekom, S. 27-33.

Kolb, D. A. (1984): Experiential Learning: Experience as the Source of Learning and Development. Englewood Cliffs, N.J.: Prentice-Hall.

Lange Salvia, A./Leal Filho, W./Londero Brandli, L./Sapper Griebeler, J. (2019): Assessing research trends related to Sustainable Development Goals: local and global issues. In: Journal of Cleaner Production 208: 841-849.

Lotz-Sisitka, H./Wals, A. E./Kronlid, D./McGarry, D. (2015): Transformative, transgressive social learning: rethinking higher education pedagogy in times of systemic global dysfunction. In: Current Opinion in Environmental Sustainability 16: $73-80$.

Messner, D./Scholz, I. (2015): Gemeinsam für das Wohlergehen aller. Agenda 2030 und die Sustainable Development Goals. In: oekom e.V. - Verein für ökologische Kommunikation (Hrsg.): Nachhaltige Entwicklungsziele. Agenda für eine bessere Welt? (Politische Ökologie, 143). München: Oekom, S. 18-26.

Mezirow, J. (2000): Learning as transformation: critical perspectives on a theory in progress. San Francisco: Jossey-Bass. 
Müller-Christ, G./Giesenbauer, B./Tegeler, M. K. (2018): Die Umsetzung der SDGs im deutschen Bildungssystem - Studie im Auftrag des Rats für Nachhaltige Entwicklung der Bundesregierung. In: ZEP - Zeitschrift für internationale Bildungsforschung und Entwicklungspädagogik 41(2): 19-26.

Nationale Plattform Bildung für nachhaltige Entwicklung (2017): Nationaler Aktionsplan Bildung für nachhaltige Entwicklung. Der deutsche Beitrag zum UNESCOWeltaktionsprogramm.

http://www.bneportal.de/sites/default/files/Nationaler_Aktionsplan_BNE_2017.pdf [Zugriff: 03.05.2019].

Overwien, B. (2013): Kompetenzmodelle im Lernbereich „Globale Entwicklung“ Bildung für nachhaltige Entwicklung. In: Overwien, B./Rode, H. (Hrsg.): Bildung für nachhaltige Entwicklung. Lebenslanges Lernen, Kompetenz und gesellschaftliche Teilhabe. Leverkusen: Budrich, S. 13-34.

Rieckmann, M. (2012): Future-oriented higher education: Which key competencies should be fostered through university teaching and learning? Futures 44(2): 127135.

Rieckmann, M. (2013): Schlüsselkompetenzen für eine nachhaltige Entwicklung. POLIS 4/2013: 11-14.

Rieckmann, M: (2018): Chapter 2 - Learning to transform the world: key competencies in ESD. In: Leicht, A./Heiss, J./Byun, W. J. (Hrsg.): Issues and trends in Education for Sustainable Development. Paris: UNESCO, S. 39-59. http://unesdoc.unesco.org/images/0026/002614/261445E.pdf [Zugriff: 03.05.2019].

Rieckmann, M./Schank, C. (2016): Sozioökonomisch fundierte Bildung für nachhaltige Entwicklung - Kompetenzentwicklung und Werteorientierungen zwischen individueller Verantwortung und struktureller Transformation. In: SOCIENCE 1(1): 65-79. http://www.rce-vienna.at/SOCIENCE/vol1.pdf. [Zugriff: 18.05.2018].

Rychen, D. S. (2003): Key competencies: Meeting important challenges in life. In: Rychen, D. S./Salganik, L. H. (Hrsg.): Key competencies for a successful life and well-functioning society. Cambridge, MA: Hogrefe and Huber, S. 63-107.

Scholz, I. (2015): Universelle Ziele für eine nachhaltige Entwicklung. In: Leitschuh, H./Michelsen, G./Simonis, U. E./Sommer, J./von Weizsäcker, E. U. (Hrsg.): Gesucht: Weltumweltpolitik. Herausforderungen im Anthropozän. Stuttgart: Hirzel (Jahrbuch Ökologie, 2016), S. 116-125.

Scholz, I. (2017): Herausforderung Sustainable Development Goals. In: Michelsen, G. (Hrsg.): Die deutsche Nachhaltigkeitsstrategie. Wegweiser für eine Politik der Nachhaltigkeit. Wiesbaden: Hessische Landeszentrale für politische Bildung, S. 23-39.

Slavich, G. M./Zimbardo, P. G. (2012): Transformational Teaching: Theoretical Underpinnings. Basic Principles, and Core Methods. In: Educational Psychology Review 24(4): 569-608. 
UNESCO (United Nations Educational, Scientific and Cultural Organization) (2014): UNESCO Roadmap zur Umsetzung des Weltaktionsprogramms „Bildung für nachhaltige Entwicklung“. https://www.bmbf.de/files/2015_Roadmap_deutsch.pdf [Zugriff: 03.05.2019].

UNESCO (United Nations Educational, Scientific and Cultural Organization) (2015a): Global Citizenship Education: Topics and learning objectives. Paris: UNESCO. http://unesdoc.unesco.org/images/0023/002329/232993e.pdf [Zugriff: 03.05.2019].

UNESCO (United Nations Educational, Scientific and Cultural Organization) (2015b): Rethinking Education. Towards a global common good? Paris: UNESCO. http://unesdoc.unesco.org/images/0023/002325/232555e.pdf [Zugriff: 03.05.2019].

UNESCO (United Nations Educational, Scientific and Cultural Organization) (2017): Education for Sustainable Development Goals. Learning Objectives. Paris: UNESCO. http://unesdoc.unesco.org/images/0024/002474/247444e.pdf [Zugriff: 03.05.2019].

Vereinte Nationen (2015): Transformation unserer Welt: die Agenda 2030 für nachhaltige Entwicklung. http://www.un.org/depts/german/gv-70/band1/ar70001.pdf [Zugriff: 03.05.2019].

Wals, A. E. J. (2015): Beyond unreasonable doubt. Education and learning for socioecological sustainability in the Anthropocene. Wageningen, Wageningen University.

https://arjenwals.files.wordpress.com/2016/02/8412100972_rvb_inauguratiewals_oratieboekje_v02.pdf [Zugriff: 03.05.2019].

Wals, A. E. J./Lenglet, F. (2016): Sustainability citizens: Collaborative and disruptive social learning. In: Horne, R./Fien, J./Beza, B. B./Nelson, A. (Hrsg.): Sustainability Citizenship in Cities: Theory and Practice, London: Routledge, S. 52-66.

Weinert, F. E. (2001): Concept of Competence: A Conceptual Clarification. In: Rychen, D. S./Salganik, L. H. (Hrsg.): Defining and Selecting Key Competencies. Seattle, Toronto, Bern, Göttingen: Hogrefe und Huber, S. 45-65.

Wiek, A./Withycombe, L./Redman, C. L. (2011): Key competencies in sustainability: a reference framework for academic program development. In: Sustainability Science 6(2): 203-218.

Wiek, A./Bernstein, M. J./Foley, R. W./Cohen, M./Forrest, N./Kuzdas, C./Kay, B./ Withycombe Keeler, L. (2016): Operationalising competencies in higher education for sustainable development. In: Barth, M./Michelsen, G./Thomas, I./ Rieckmann, M. (Hrsg.): Routledge Handbook of Higher Education for Sustainable Development. London: Routledge, S. 241-260. 


\title{
4 Nationales Monitoring von BNE - Stand und Prozess der Verbreitung von BNE in Deutschland
}

\author{
Mandy Singer-Brodowski, Nadine Etzkorn, Antje Brock, \\ Theresa Grapentin-Rimek, Janne von Seggern
}

\subsection{Bedeutung nationaler Monitoring-Ansätze im Kontext BNE}

Die internationale Nachhaltigkeitsagenda der Sustainable Development Goals (SDGs) und das UNESCO-Weltaktionsprogramm „Bildung für nachhaltige Entwicklung“ (WAP BNE) (2015-2019) stellen einen wesentlichen Auftrag für Politik, (zivil-)gesellschaftliche und private Akteure sowie nicht zuletzt für die Wissenschaft dar. Mit dem internationalen Bedeutungszuwachs von BNE in den vergangenen Jahren wird dabei auch das Monitoring nationaler Entwicklungstendenzen von BNE-Aktivitäten immer wichtiger. Die Governance von BNE ist in vielen Ländern eher polyzentrisch aufgestellt und die Aktivitäten umfassen sowohl staatliche als auch zivilgesellschaftliche und private Akteure (Feinstein et al. 2013). Forschungsprojekte können hier zur Generierung eines systematischen Wissensstands zur BNE-Verankerung in einem Land beitragen. Ein Bildungsmonitoring wird dabei von Döbert und Weißhaupt (2012) beschrieben als ein:

„,kontinuierlicher, datengestützter Beobachtungs- und Analyseprozess des Bildungswesens insgesamt sowie einzelner seiner Bereiche bzw. Teile zum Zweck der Information von Bildungspolitik und Öffentlichkeit über Rahmenbedingungen, Verlaufsmerkmale, Ergebnisse und Erträge von Bildungsprozessen.“ (Döbert/Weißhaupt 2012, S. 158)

Ein BNE-Monitoring sollte in diesem Sinne das Ziel verfolgen, Bildungspolitik und interessierte Öffentlichkeit zu informieren sowie systematisch Wissen zur Unterstützung politischer Bemühungen um eine stärkere BNEImplementierung zu generieren. In der Regel basiert ein Bildungsmonitoring auf Indikatoren. Die UN-Dekade BNE hat sowohl zu zahlreichen Indikatoren über die Verankerung der BNE (z.B. UNECE 2007) wie auch zu vielfältigen Monitoring-Ansätzen (z.B. UNESCO 2014) geführt. Viele dieser Monito- 
ring-Projekte waren jedoch in der Rückschau wenig kontextsensibel (Lockhart 2018). Basierend auf diesen Erfahrungen gilt es für das WAP BNE Monitoring-Ansätze zu konzipieren, die multiperspektivisch und kontextsensibel sind sowie verschiedene Forschungsmethoden integrieren (vgl. ebd.). Zudem ist es wichtig, eine unabhängige Erhebung und Auswertung der Daten im Rahmen von Monitoring-Ansätzen zu gewährleisten, weil viele internationale BNE-Berichte auf positiven Selbstdarstellungen der Regierungen basieren (Nazir et al. 2009).

Vor diesem Hintergrund wurde zur Erfassung des Ist-Standes und der Prozesse der Verankerung von BNE in Deutschland ein umfassender Monitoring-Prozess konzipiert und eine Dokumentenanalyse (1. Phase), eine groß angelegte Interviewstudie mit 66 Expert*innen (2. Phase), eine quantitative Studie $(n=3.000)$ zu Wissen, Einstellungen, Verhalten und institutioneller Implementierung von BNE und Nachhaltigkeit bei jungen Menschen und Lehrkräften (3. Phase) sowie eine Wiederholung der Dokumentenanalyse (4. Phase) durchgeführt (für Überblicke über die deutschlandweite BNEImplementierung und weitere nachhaltigkeitsrelevante Dimensionen siehe: Grund/Brock 2018; Brock/Grund 2018). Damit sollte dem Anspruch der Verschränkung von verschiedenen Forschungsmethoden Rechnung getragen werden. In diesem Beitrag werden neben der Beschreibung des Forschungsprojektes die Ergebnisse der ersten und zweiten Forschungsphase vorgestellt, die einen Überblick zur BNE-Verankerung in den verschiedenen Bereichen des deutschen Bildungssystems geben.

\subsection{Die Umsetzung des Weltaktionsprogramms in Deutschland und die Konzeption des nationalen BNE- Monitorings}

Zur Umsetzung des WAP BNE hat das Bundesministerium für Bildung und Forschung (BMBF) die Koordinierung übernommen und einen umfassenden Stakeholder-Prozess mit einer Nationalen Plattform, sechs Fachforen, einem Jugendforum und verschiedenen Partnernetzwerken initiiert. Die Fachforen für die Bildungsbereiche frühkindliche Bildung, Schule, berufliche Bildung, Hochschule und non-formales und informelles Lernen/Jugend sowie für Kommunen haben seit 2016 einen Nationalen Aktionsplan Bildung für nachhaltige Entwicklung (NAP) erarbeitet, der am 20.06.2017 von der Nationalen Plattform beschlossen wurde (BMBF 2017). In den folgenden Jahren steht die Umsetzung dieses Referenzdokumentes als Rahmen der BNEVerankerung im Mittelpunkt. 
Der Umsetzungsprozess des WAP wird von einem internationalen Berater (Walter Hirche, Deutsche UNESCO-Kommission) und einem wissenschaftlichen Berater (Prof. Dr. Gerhard de Haan, FU Berlin) begleitet. Während die Deutsche UNESCO-Kommission mit dem BMBF die Auszeichnung von besonders engagierten Lernorten, Netzwerken und Kommunen sowie die Anbindung an internationale BNE-Prozesse und das BNE-Portal verantwortet, ist die wissenschaftliche Beratung für die permanente Reflexion der Governance-Prozesse im Multistakeholder-Prozess sowie der kontinuierlichen Erfassung der BNE-Verankerung in Deutschland verantwortlich. Das Monitoring zielt damit auf die Generierung von Wissen zum Implementierungsstand von BNE in den einzelnen Bildungsbereichen in Deutschland.

Weiterhin verfolgt es den Anspruch, Erkenntnisse zur Diffusion von BNE als soziale Innovation (Bormann 2013) und zu Hebelpunkten (Meadows 1999) zur weiteren Verbreitung von BNE in einzelnen Bildungsbereichen zu gewinnen und nicht zuletzt die Wirkung von BNE in der Bildungspraxis zu eruieren. Besonders die erste und vierte Phase des Forschungsprojektes (Desk Research/Dokumentenanalyse) ist damit an ein enges Verständnis von indikatorenbasiertem Bildungsmonitoring angelehnt und erlaubt den systematischen Überblick zum Verankerungsstand von BNE und verwandten Konzepten - wie Umweltbildung und Globales Lernen - in den einzelnen Bildungsbereichen (für eine ausführliche Darstellung des methodischen Vorgehens und der Ergebnisse vgl. Brock et al. 2018). Die zweite Phase der Expert*inneninterviews (Erhebungszeitraum Juni bis Oktober 2017) verfolgte das Ziel, die Diffusion von BNE in den vergangenen Jahren besser zu verstehen und besondere Merkmale und Entwicklungen der jeweiligen Bildungsbereiche zu ergründen, in die BNE hineindiffundiert.1 Zusammen ergeben die Ergebnisse aus beiden Phasen ein differenziertes Bild zur Verankerung von BNE, das in den nächsten Forschungsphasen (3 und 4) vertieft und erweitert wird.

1 Die Ergebnisse dieser Interviewstudie sind im Barbara Budrich Verlag erschienen (SingerBrodowski et al. 2019). 


\subsection{Frühkindliche Bildung}

\subsubsection{Ergebnisse der Desk Research}

Im Rahmen der Desk Research wurden zentrale Dokumente im frühkindlichen Bildungsbereich untersucht (für Ergebnisse im Detail vgl. SingerBrodowski 2018). In den politisch relevanten Rahmendokumenten (gesetzliche Vorgaben, JFMK-Beschlüsse, Nationaler Bildungsbericht) wurde keine Verankerung von BNE festgestellt. Dagegen konnte in den Bildungsplänen der Bundesländer eine sehr diverse und in manchen Ländern in den letzten Jahren deutlich zunehmende Thematisierung von BNE und verwandten Konzepten konstatiert werden. In den Studiengängen der frühkindlichen Bildung wurde in $45,6 \%$ der analysierten Studiengänge eine Verankerung von BNE und verwandten Konzepten identifiziert - allerdings mit einem starken Fokus auf Umweltbildung oder Interkulturelles Lernen. Die Lehrpläne für die Ausbildung von Erzieher*innen oder den vorbereitenden Berufen stellen dagegen ein großes Desiderat dar. Für die Fort- und Weiterbildungen pädagogischer Fachkräfte konnten im Rahmen einer Literaturanalyse Qualitätskriterien identifiziert werden. Insgesamt hat BNE im Bereich der frühkindlichen Bildung in allen Dokumententypen an Bedeutung gewonnen - außer in den politisch relevanten Rahmendokumenten.

\subsubsection{Ergebnisse der Expert*innen-Interviews}

In den letzten Jahren haben vielfältige gesellschaftliche und politische Veränderungen (z.B. Rechtsanspruch auf Betreuungsplatz, Qualitätsentwicklung, Inklusion etc.) den frühkindlichen Bildungsbereich geprägt. Diese dynamischen Veränderungen erleichterten die Aufnahme von BNE insofern, als dass die hohe Veränderungsdynamik und Offenheit der Akteure des frühkindlichen Bildungssystems einen fruchtbaren Boden für die Aufnahme von BNE boten. Dabei wurde die frühkindliche Bildung erst im Laufe der UN-Dekade $\mathrm{BNE}$ als ein eigenständiger Bildungsbereich für die Praxis von BNE erschlossen. Die Expert*innen der Interviewstudie konstatieren, dass zwar noch lange nicht alle Akteure und Einrichtungen erreicht sind und viele pädagogische Aktivitäten im Kontext von Nachhaltigkeit in den Kindertageseinrichtungen noch nicht mit dem umfassenden Bildungskonzept BNE in Verbindung gebracht werden. Dennoch beobachten auch sie einen langsam steigenden Verankerungsgrad in den Bildungsplänen für die ersten Lebensjahre sowie in den Kindertageseinrichtungen. $\mathrm{Zu}$ diesem tendenziell erfolgreichen Diffusionsprozess von BNE haben auch groß angelegte Modellprojekte 
(Leuchtpol, Kita21), Veranstaltungen sowie ein internationaler Austausch beigetragen. Weiterhin haben die Auszeichnungen eine wichtige Funktion für die Anerkennung ehrenamtlicher Arbeit erfüllt. Eine wesentliche Hebelwirkung haben nach Einschätzung der Expert*innen vor allem die Träger von Kindertageseinrichtungen, die BNE in ihr Leitbild aufnehmen und die Einrichtungen in der Qualitätsentwicklung in Richtung BNE unterstützen können.

\subsection{Schule}

\subsubsection{Ergebnisse der Desk Research}

Die Desk Research im Bereich Schule umfasste zentrale Dokumente wie Bildungs- bzw. Lehrpläne ausgewählter Bundesländer, Bildungsstandards, Schulgesetze, Beschlüsse und Empfehlungen der Kultusministerkonferenz (KMK), Einheitliche Prüfungsanforderungen in der Abiturprüfung (EPAs), lehramtsrelevante Modulbeschreibungen sowie Studien-/Prüfungsordnungen u.Ä. (für eine detaillierte Darstellung des methodischen Vorgehens und der Ergebnisse, siehe Brock 2018a). Die Ergebnisse zeigen die hohe Heterogenität der Verweise auf BNE und verwandte Konzepte auf mehreren Ebenen. Die Qualität und Anzahl der Verweise auf BNE variiert stark und wenig überraschend zwischen einzelnen Fächerbezügen: Innerhalb von Dokumenten im Kontext BNE-affiner Fächer (Biologie, Geografie, Sachunterricht) ist das Konzept deutlich stärker verbreitet. Dies zeigt sich sowohl in den Curricula, Bildungsstandards, EPAs als auch in den lehramtsrelevanten Dokumenten. Auch auf der Ebene von Bundesländern lassen sich klare Unterschiede erkennen. Nur sehr punktuelle Bezüge zu (B)NE weisen Schulgesetze ausgewählter Bundesländer sowie die untersuchten KMK-Beschlüsse auf. Über alle untersuchten Dokumentengruppen im Bereich Schule hinweg zeichnet sich das Bild ab, dass es insgesamt trotz eindeutig steigender Tendenz ein noch erhebliches Potential der BNE-Verankerung gibt, insbesondere in verbindlichen Dokumententypen.

\subsubsection{Ergebnisse der Expert*innen-Interviews}

Der Bildungsbereich Schule ist kontinuierlich inhaltlichen (z.B. Inklusion, Flucht) und strukturellen (G12, Ganztagsschule) Neuerungen unterworfen. Die Expert*innen sehen ihn durch eine Top-Down-Dynamik geprägt, die sich 
auf die Länderhoheit und mit ihr einhergehende komplexe Abstimmungsund Kommunikationsprozesse bezieht. Diese bedingen u.a., dass Schulen eher auf bildungspolitische Reformen reagieren und die Akzeptanz der Schulen gegenüber einzelnen Themen erst dann steigt, wenn eine entsprechende bildungspolitische Relevanz besteht. Die Diffusion von BNE wird, deckungsgleich mit den Ergebnissen der Desk Research, als stark bundeslandabhängig sowie als langsam und punktuell eingeschätzt. Unterstützend wirkt dabei eine zunehmende Relevanz der Ganztagsschulen, die auch die Bedeutung von lokalen Bildungslandschaften stärkt. BNE wird von Lehrkräften insbesondere in der Abgrenzung zu anderen Bildungskonzepten als komplex empfunden, weswegen die fachspezifische Umsetzung noch immer Fragen aufwirft. Die Expert*innen identifizieren die Qualifizierung des Lehrpersonals, rechtliche Rahmenvorgaben, finanzielle Ressourcen (besonders bei Personal) und eine öffentliche Diskussion um BNE, sowie neue Lernformate, -methoden und Good-Practice-Beispiele als starke Hebelpunkte im Diffusionsprozess. Schüler*innen, Lehr- und Schulleitungspersonal, Eltern sowie BNE unterstützende Politiker*innen werden dabei als entscheidende Akteure definiert.

\subsection{Duale berufliche Ausbildung}

\subsubsection{Ergebnisse der Desk Research}

Für die duale berufliche Ausbildung wurde eine Vielzahl verschiedener Dokumententypen untersucht (zum Vorgehen und den Ergebnissen im Detail siehe Otte/Singer-Brodowski 2018): Bundesgesetze, Landesschulgesetze von fünf Bundesländern, Empfehlungen des Hauptausschusses des Bundesinstituts für Berufsbildung (BIBB), Beschlüsse und Veröffentlichungen der KMK zur beruflichen Bildung und zur Lehrerbildung, der Berufsbildungsbericht des BMBF und der dazugehörige Datenreport des BIBB, sowie Ausbildungsordnungen und Rahmenlehrpläne der KMK zu 14 ausgewählten Berufsausbildungen. Nicht zuletzt wurden die Verordnungen zu den Aufstiegsfortbildungen und die Modulbeschreibungen aus der Berufslehrerbildung ausgewählter Hochschulen analysiert. Als zentraler Befund lässt sich konstatieren, dass BNE und verwandte Bildungskonzepte in den analysierten Dokumenten

noch eine geringe Rolle spielen. Zwar wurde für die Analyse der Dokumente in diesem Bildungsbereich in Abstimmung mit Expert*innen neben der Schlagwortliste aus Bildungskonzepten eine erweiterte Schlagwortliste zur Analyse genutzt, die auch Themenstellungen der Nachhaltigkeit (wie etwa Umwelt, Gerechtigkeit, Biodiversität oder Klima) umfasste. Dennoch erwies 
sich der Verankerungsgrad als gering - auch im Vergleich zu den anderen Bildungsbereichen. Allerdings gibt es in der beruflichen Bildung eine lange Tradition der Verankerung von Umweltschutz z.B. in den Ausbildungsordnungen, die auf eine Empfehlung des BIBB-Hauptausschusses aus dem Jahr 1991 zurückgeht.

\subsubsection{Ergebnisse der Expert*innen-Interviews}

Berufliche Bildung zielt auf die berufsspezifische Handlungsfähigkeit sowie auf die verantwortliche Rolle der Auszubildenden als Bürger*innen. Die Handlungsorientierung in der Bildungssituation und das Konsens-Prinzip u.a. mit den Sozialpartnern (z.B. für die Aushandlung neuer Ordnungen) sind zentrale Merkmale des Bildungsbereiches, die auch für die BNEImplementierung strukturgebend sind. Nicht zuletzt ist der Bildungsbereich stark von wirtschaftlichen und gesellschaftlichen Prioritätensetzungen und Innovationen geprägt. Die Expert*innen beschreiben, dass die Diffusion von (B)NE lange über das Vehikel des Umweltschutzes erfolgte und bestätigen damit die Ergebnisse der Desk Research. Auch die Modellprojekte des BIBB haben wichtige Impulse gesetzt. Neue Geschäfts- und Wirtschaftsmodelle (green jobs, CSR- und Nachhaltigkeitsberichte) stärken derzeit die zunehmenden Verankerungstendenzen von (B)NE. Die Aushandlung über und Gleichberechtigung von Nachhaltigkeitsdimensionen sowie der (vermeidende) Umgang mit Widersprüchen und Zielkonflikten in beruflichen Handlungssituationen sind dabei wichtige Faktoren, die wiederum stark vom Konsensprinzip des Bildungsbereiches geprägt zu sein scheinen. Als wesentliche Hebelpunkte beschreiben die Interviewten eine betriebs-, berufs- und branchenspezifische Differenzierung, die Etablierung übergreifender (Austausch-) Plattformen zur Darstellung von Good-Practice, die stärkere Vernetzung in lokalen Bildungslandschaften, die Initiierung einer Weiterbildungsoffensive für alle Berufsbildungsakteure sowie eine neue BIBB-HauptausschussEmpfehlung zu Nachhaltigkeit.

\subsection{Hochschule}

\subsubsection{Ergebnisse der Desk Research}

Die Dokumentenanalyse zeigte, dass BNE nur marginal in den analysierten zentralen Dokumenten des Hochschulbereichs zu finden ist, für Nachhaltig- 
keit und nachhaltige Entwicklung (NE) jedoch ein deutlicher Zuwachs verzeichnet werden kann (zum Vorgehen und den Ergebnissen im Detail siehe Etzkorn/Singer-Brodowski 2018). Die Analyse der politisch relevanten Rahmendokumente wie Hochschulgesetze, (Landes-)Hochschulentwicklungspläne, Ziel- und Leistungsvereinbarungen, HRK- und LRK-Beschlüsse, ergab große landesspezifische Unterschiede. Insbesondere die konsequente Verschränkung verschiedener wissenschafts- und hochschulpolitischer Steuerungsinstrumente einiger Bundesländer hat sich positiv auf die strukturelle Verankerung von (B)NE ausgewirkt. In den untersuchten Studiengängen (Biologie, Maschinenbau, BWL) von 15 ausgewählten Hochschulen zeichnet sich eine deutliche Verankerung von (B)NE und verwandten Konzepten ab. Die Analysen der Leitbilder und Nachhaltigkeitsberichte der untersuchten Hochschulen zeigen, dass hier besonders bei den identifizierten LeuchtturmHochschulen (z.B. Hochschule für nachhaltige Entwicklung Eberswalde und Leuphana Universität Lüneburg) ein umfangreicher Bezug zu (B)NE zu erkennen ist. Dagegen ergab die Untersuchung der Stellungnahmen und Positionen der Fakultätentage kaum Hinweise auf eine Implementierung von (B)NE. Insgesamt zeigt sich im Bereich Hochschule ein positiver Entwicklungstrend hinsichtlich der Verankerung von NE, der sich jedoch noch nicht auf die Thematisierung von BNE als Bildungskonzept niedergeschlagen hat.

\subsubsection{Ergebnisse der Expert*innen-Interviews}

In den letzten Jahren waren Hochschulen mit vielen parallelen Herausforderungen und Entwicklungen konfrontiert (z.B. Inklusion, Flucht, Migration, Digitalisierung), wodurch die Verbreitung von (B)NE als weitere Querschnittsaufgabe eher verlangsamt wurde. Insgesamt schätzen die Expert*innen den Diffusionsprozess von (B)NE in Hochschulen als differenziert, heterogen und ausbaufähig ein. Sie berichten in den Interviews von engagierten Hochschullehrenden sowie von studentischen Initiativen und Netzwerken, die seit der UN-Dekade BNE wesentliche Treiber für die Verbreitung von BNE an Hochschulen waren. Die Autonomie der Hochschulen und die Strukturierung in Disziplinen als Charakteristika der Hochschulen einerseits sowie die inter- und transdisziplinären Forschungs-, Lehr- und Lernsettings als auch die Praxisrelevanz als hochschulspezifische Merkmale der BNE andererseits haben sich in doppelter Weise hinderlich auf den Diffusionsprozess der (B)NE ausgewirkt: Die Merkmale des Hochschulbereichs stehen einer Aufnahme und Verbreitung der BNE in Hochschulen tendenziell resistent gegenüber, da BNE historisch gewachsene (disziplinäre) Selbstverständnisse in der Wissenschaft herausfordert. Trotz diffusionshinderlichen Bedingungen im Hochschulsystem haben die Interviewten Hebelpunkte iden- 
tifiziert, die nach ihrer Einschätzung zur strukturellen Verankerung von BNE in Hochschulen beitragen können. Insbesondere der Whole-InstitutionApproach, die Rolle der Hochschulleitung und politische Rahmendokumente sowie die Hochschulfinanzierung werden als Hebel mit Wirkung betrachtet, um (B)NE stärker in den hochschulischen Strukturen zu verankern.

\subsection{Kommune}

\subsubsection{Ergebnisse der Desk Research}

In der Dokumentenanalyse wurde ein Sample aus 121 Kommunen berücksichtigt, die innerhalb der letzten fünf Jahre bei thematisch einschlägigen Wettbewerben und (Förder-)Programmen nominiert wurden bzw. sich engagiert haben (für das methodische Vorgehen und die Ergebnisse im Detail vgl. Brock 2018b). Für diese Kommunen wurden die Bildungs- und Nachhaltigkeitsberichte und -leitbilder, Strukturentwicklungsberichte, Zukunftsleitbilder sowie die Webseiten dieser Kommunen anhand eines Rasters BNE-relevanter Kriterien untersucht. Aus der Analyse wird deutlich, dass Bildungs- und Nachhaltigkeitsberichte/-leitbilder nur von einem geringen Teil der Kommunen vorliegen und die vorliegenden Bildungs-, Nachhaltigkeits- und Strukturentwicklungsberichte nur wenige BNE-relevante Treffer aufweisen.

Die Analyse der Webseiten ergab, dass bei 42 der 121 Kommunen keine Hinweise auf BNE und Nachhaltigkeitsthemen auf den ersten 3 Klick-Ebenen ihres Internetauftritts zu finden sind. Sind grafische oder textliche Verweise auszumachen, beziehen diese sich mehrheitlich auf Nachhaltigkeit im allgemeineren Sinne, nicht dezidiert auf BNE. Weiterhin geben 42 der untersuchten Kommunen eine Ansprechperson für BNE oder Nachhaltigkeit auf ihren Webseiten an. Es zeigt sich also selbst bei BNE-affinen Kommunen noch großes Potential, BNE sichtbarer werden zu lassen und Bildungs- sowie Nachhaltigkeitsbestrebungen im Berichtswesen und durch kommunale Internetpräsenz stärker zusammenzudenken.

\subsubsection{Ergebnisse der Expert*innen-Interviews}

Kommunen sind in den letzten Jahren mit vielfachen gesellschaftlichen Aufgaben und Herausforderungen konfrontiert, auf die sie unmittelbar reagieren und Lösungsstrategien entwickeln müssen. Die Expert*innen beschreiben, dass Bildung in den vergangenen Jahren dennoch von den Kommunen stärker 
als eine „Aufgabe“ wahrgenommen wird. Gleichwohl wird Bildung und konkreter BNE nicht als eine Kernaufgabe der kommunalen Ebenen verstanden. Auf kommunale Veränderungsprozesse allgemein wirkt eine Verschränkung der verschiedenen Policy-Ebenen von internationalen bis hin zu nationalen und länderweiten Impulsen, die auf die lokale Ebene übersetzt, aber selten kontextualisiert werden (Temenos/McCann 2012). Kommunen sind jedoch gerade aufgrund ihrer jeweiligen kontextspezifischen Einflussfaktoren (z.B. Größe, Policy- und lokale Governance-Modi) bei der BNE-Diffusion sehr unterschiedlich. Ein Transfer von Erfolgsrezepten ist deshalb selten möglich und ein Upscaling von BNE scheint herausfordernder als in anderen Bereichen. Vielfach sind auf kommunaler Ebene Aktivitäten und Projekte zu verzeichnen, die aber nicht unter dem „Label“ BNE zusammengefasst werden. Eine wesentliche Rolle in der BNE-Diffusion kommt daher der Sichtbarmachung der lokalen (B)NE-Aktivitäten zu. Auch kommunale Klimaschutzmaßnahmen sowie die Sustainable Development Goals befördern lokale (B)NE-Prozesse. Darüber hinaus macht die besondere Bedeutung von lokalen Netzwerken Ansprechpartner*innen und offiziell Verantwortliche auf lokaler Ebene besonders wichtig. Aus Sicht der Expert*innen ist es zentral, die Vorteile und den Mehrwert von BNE prominent darzustellen, damit auch die Bürgermeister*innen einzubinden und nicht zuletzt neue Kommunen anzusprechen.

\subsection{Non-formales und informelles Lernen}

Der Bereich des non-formalen und informellen Lernens konnte im Rahmen der ersten Phase des Monitorings nicht untersucht werden, da es in diesem Bildungsbereich im Vergleich $\mathrm{zu}$ den formalen Bildungsbereichen keine einheitliche Datengrundlage an verbindlichen und orientierenden Dokumenten für die einzelnen Bildungseinrichtungen gibt. Vielmehr ist die Landschaft derjenigen Akteure und Träger, die non-formale Bildungsangebote konzipieren und durchführen, durch eine große Heterogenität bezüglich der Institutionen (von selbstständigen Umweltbildungsreferent*innen bis hin zu zivilgesellschaftlichen Dachverbänden) und inhaltlichen Ausrichtungen (Globales Lernen, Umweltbildung, kulturelle Bildung etc.) geprägt. Diese Vielfalt wurde auch in der Kontrastierung der neun Interviewpartner*innen für die zweite Phase des Monitorings berücksichtigt. Nach Einschätzung der befragten Expert*innen eint die Bildungsanbieter jedoch ein spezifisches Bildungsverständnis in non-formalen Angeboten: diese sind freiwillig, bedarfsorientiert, partizipativ, experimentell und gestaltungsoffen. Aus der Perspektive der 
Interviewten kritisieren und ergänzen die non-formalen Bildungsanbieter den formalen Bildungsbereich dort, wo er gesellschaftliche Herausforderungen nicht adäquat aufzugreifen vermag und tragen damit zu einer Öffnung des formalen Bildungssystems bei.

Da die Nachfragen aus dem formalen Bildungssystem nach non-formalen Bildungsangeboten in den letzten Jahren gestiegen sind, haben sich die nonformalen Angebote zu BNE aus Sicht der Interviewten professionalisiert, ausdifferenziert und quantitativ ausgeweitet. Begleitet ist diese verstärkte Ausdifferenzierung von einer zunehmenden institutionellen Verschränkung des formalen und non-formalen Bildungsbereichs: Non-formale Angebote im Ganztag, Bildungslandschaften und Kooperationsstellen zwischen entwicklungspolitischen NGOs und Schulen sind Beispiele dafür. Diese zunehmende institutionelle Verschränkung hat zu einer Entgrenzung beider Bereiche beigetragen (dazu schon Rauschenbach et al. 2004). Einerseits unterstützt diese Entwicklung die Durchführung non-formaler Bildungsangebote. Andererseits führt sie nach Einschätzung der Interviewten zu einer Tendenz der Formalisierung non-formaler Angebote. Des Weiteren wird von den Interviewten ein Rollenwandel der zivilgesellschaftlichen Bildungsanbieter von Lobbyorganisationen für BNE im formalen Bildungssystem hin zu Lernorten in Kooperation mit den formalen Bildungseinrichtungen konstatiert. Vor dem Hintergrund dieser Veränderungen ist ein wesentlicher Hebelpunkt zur weiteren Stärkung von BNE das Initiieren von Diskursräumen zur Reflexion und Selbstvergewisserung über die eigene Rolle. Diese Selbstvergewisserung der non-formalen Bildungsträger ist auch im Hinblick auf die Verortung innerhalb verschiedener Bildungskonzepte wichtig.

\subsection{Jugend}

Junge Menschen sind bisher unterschätzte Change Agents und Promotor*innen in der Verbreitung der BNE. Im WAP BNE sind Jugendliche ein Schwerpunkt und sollen zur Förderung einer nachhaltigeren Zukunft gestärkt, mobilisiert und als Gestalter*innen des Wandels adressiert werden (UNESCO 2014, S. 15).

Im Mittelpunkt der insgesamt zehn durchgeführten Interviews stand die Erforschung von Potentialen der Jugendbeteiligung zur Umsetzung des WAP BNE, aber auch Herausforderungen, Notwendigkeiten sowie Grenzen in der Jugendbeteiligung. Die Ergebnisse der Interviews mit jungen Menschen und Erwachsenen weisen darauf hin, dass es eine zentrale Aufgabe ist, Jugendbe- 
teiligung für BNE auf dem Weg von aktionsorientiertem hin zu institutionalisierten Formen des Engagements zu fördern.

Studien zu jugendlichem Partizipationsverhalten stellen immer wieder eine Präferenz für themenorientiertes, zeitlich begrenztes und projektbezogenes Engagement fest. Zu diesem Schluss kommt auch die Jugendstudie des BMUB 2018 ,Zukunft? Jugend fragen!“”, in der mehr als 1000 junge Menschen zwischen 14 und 22 Jahren in einer repräsentativen Umfrage zu ihren Einstellungen zu Nachhaltigkeit, Politik und Engagement sowie zu ihrem Alltag befragt wurden: Das Interesse ist höher als die tatsächliche Bereitschaft sich zu engagieren. Zudem dominieren unverbindliche Formen des Engagements ein formal organisiertes Aktivsein (z.B. Natur- oder Umweltschutzgruppe) (BMUB 2018, S. 46 ff.).

Vor diesem Hintergrund ist für die weitere Ausgestaltung von institutionalisierten jugendlichen Beteiligungsprozessen darauf $\mathrm{zu}$ achten, unterschiedliche Formate $\mathrm{zu}$ schaffen und Partizipationsstrukturen $\mathrm{zu}$ flexibilisieren sowie die Interessen und Stärken von jungen Menschen aufzugreifen und ihnen Möglichkeiten zur Übernahme von politischer und formaler Verantwortung zu geben. Darüber hinaus sollten Rahmenbedingungen so gestaltet werden, dass die jungen Menschen dazu ermutigt werden, eigene Projektideen zu entwickeln und bei der Erfüllung ihrer Aufgaben unterstützt und pädagogisch begleitet werden. Für eine wirksame Jugendbeteiligung ist die Zusammenarbeit politischer, zivilgesellschaftlicher und kommunaler Akteure von großer Bedeutung, um jungen Menschen eine Stimme auf der politischen Bühne zu verleihen und sie an der Erarbeitung von Lösungen zur Förderung einer nachhaltigen Entwicklung wirksam zu beteiligen.

\subsection{0 Übergreifende Bewertung der Ergebnisse}

Werden die Ergebnisse der Dokumentenanalyse und der Interviewstudie zusammengenommen, ergibt sich ein Bild des Standes und des Prozesses der Diffusion von BNE in Deutschland, der sehr stark zwischen den einzelnen Bundesländern, aber auch zwischen den verschiedenen Bildungsbereichen variiert. Auf der Ebene der Dokumente zeigt sich, dass BNE in den vergangenen Jahren verstärkt aufgegriffen wird und zunehmend andere Bildungskonzepte, wie Umweltbildung oder Globales Lernen, überwiegt (dazu auch van Poeck et al. 2013). Mit der ersten Desk Research wurde gleichzeitig eine Erhebung des Status Quo der BNE-Implementierung auf Dokumentenebene geschaffen, den weitere Erhebungen wiederholen und ergänzen können. Dies wird dem Anspruch eines indikatorenbasierten Bildungsmonitorings gerecht, 
wenngleich die Anzahl von Fundstellen in relevanten Dokumenten weder etwas über die Art ihrer Kontextualisierung noch etwas über die Umsetzung in der Praxis aussagen können. Daher wurde mit der Interviewstudie darauf gezielt, sich dem Prozess der Diffusion von BNE anzunähern. Besonders die Verschränkung der Dokumentenanalyse mit den Interviews hat dabei einen multiperspektischen Blick auf den Stand und Prozess der Diffusion von BNE ergeben. Die Ergebnisse der Expert*inneninterviews machen deutlich, dass ein Verständnis der allgemeinen Ziele, Merkmale und Veränderungsdynamiken im jeweils untersuchten Bildungsbereich notwendig ist, um die Diffusion und den Transfer von BNE beschreiben und darauf aufbauend auch unterstützen zu können. Ein weiteres zentrales Ergebnis der Interviewstudie ist, dass einige Merkmale von BNE als soziale Innovation einen eher diffussionshinderlichen Charakter haben, etwa da BNE komplex und durch diverse Spannungsfelder gekennzeichnet ist. Es gilt also einerseits, einen konstruktiven Umgang mit den Hürden der Diffusion zu finden. Andererseits sollten sich die Umsetzungs- und Kommunikationsaktivitäten bezüglich BNE daran orientieren, die diffusionsförderlichen Faktoren herauszustellen, wie etwa die Rolle von Bildung im Kontext einer anstehenden gesellschaftlichen Transformation durch ein kreatives, partizipatives Befähigen der Lernenden.

\section{Literatur}

BMBF (2017): Nationaler Aktionsplan Bildung für nachhaltige Entwicklung. https://www.bmbf.de/files/Nationaler\%20Aktionsplan\%20BNE\%202017.pdf [Zugriff: 30.04.2018].

BMUB (2018): Zukunft? Jugend fragen! Nachhaltigkeit, Politik, Engagement - eine Studie zu Einstellungen und Alltag junger Menschen. Bonn.

Bormann, I. (2013): Bildung für nachhaltige Entwicklung als Praxis sozialer Innovation. In: Rückert-John, J. (Hrsg.): Soziale Innovation und Nachhaltigkeit. Perspektiven sozialen Wandels. (Research). Wiesbaden: VS-Verlag, S. 269-288.

Brock, A. (2018a): Verankerung von Bildung für nachhaltige Entwicklung im Bildungsbereich Schule. In: Brock, A./de Haan, G./Etzkorn, N./Singer-Brodowski, M. (Hrsg.): Wegmarken zur Transformation. Nationales Monitoring von Bildung für nachhaltige Entwicklung in Deutschland. Opladen, Berlin, Toronto: Barbara Budrich Verlag, S. 67-116.

Brock, A. (2018b): Verankerung von Bildung für nachhaltige Entwicklung im Bildungsbereich Kommunen. In: Brock, A./de Haan, G./Etzkorn, N./SingerBrodowski, M. (Hrsg.): Wegmarken zur Transformation. Nationales Monitoring von Bildung für nachhaltige Entwicklung in Deutschland. Opladen, Berlin, Toronto: Barbara Budrich Verlag, S. 231-266. 
Brock, A./de Haan, G./Etzkorn, N./Singer-Brodowski, M. (Hrsg.) (2018): Wegmarken zur Transformation. Nationales Monitoring von Bildung für nachhaltige Entwicklung in Deutschland. Opladen, Berlin, Toronto: Barbara Budrich Verlag.

Brock, A./Grund, J. (2018): Executive Summary. Bildung für nachhaltige Entwicklung in Lehr-Lernsettings - Quantitative Studie des nationalen Monitorings - Befragung von LehrerInnen. https://www.ewi-psy.fu-berlin.de/einrichtungen/weitere/institut-futur/aktuelles/dateien/executive_summary_lehrerinnen.pdf [Zugriff: 14.05.2019].

Döbert, H./Weishaupt, H. (2012): Bildungsmonitoring. In: Wacker, A./Maier, U./ Wissinger, J. (Hrsg.): Schul- und Unterrichtsreform durch ergebnisorientierte Steuerung. Empirische Befunde und forschungsmethodische Implikationen. Wiesbaden: VS Verlag, S. 155-173.

Etzkorn, N./Singer-Brodowski, M. (2018): Verankerung von Bildung für nachhaltige Entwicklung im Bildungsbereich Hochschule. In: Brock, A./de Haan, G./Etzkorn, N./Singer-Brodowski, M. (Hrsg.): Wegmarken zur Transformation. Nationales Monitoring von Bildung für nachhaltige Entwicklung in Deutschland. Opladen, Berlin, Toronto: Barbara Budrich Verlag, S. 189-230.

Feinstein, W./Roberto, N./Jacobi, P./Lotz-Sisitka, H. (2013): When does a nationlevel analysis make sense? ESD and educational governance in Brazil, South Africa, and the USA. In: Environmental Education Research 19(2): 218-230.

Grund, J./Brock, A. (2018): Executive Summary. Bildung für nachhaltige Entwicklung in Lehr-Lernsettings. Quantitative Studie des nationalen Monitorings - Befragung junger Menschen. https://www.ewi-psy.fu-berlin.de/einrichtungen/weitere/institut-futur/aktuelles/dateien/executive_summary_junge_menschen.pdf [Zugriff: 14.05.2019].

Lockhart, A. S. (2018): Monitoring ESD: lessons learned and ways forward. In: Leicht, A./Heiss, J./Byun, W. J. (Hrsg.): Issues and trends in Education for Sustainable Development. Paris: UNESCO, S. 215-232.

Meadows, D. H. (1999): Leverage Points: Places to Intervene in a System. Hartland: The Sustainability Institute.

Nazir, J./Pedretti, E./Wallace, J./Montemurro, D./Inwood, H. (2009): Climate Change and Sustainable Development: The Response from Education. The Canadian Perspective. Toronto.

Otte, I./Singer-Brodowski, M. (2018): Verankerung von Bildung für nachhaltige Entwicklung in der dualen beruflichen Ausbildung. In: Brock, A./de Haan, G./ Etzkorn, N./Singer-Brodowski, M. (Hrsg.): Wegmarken zur Transformation. Nationales Monitoring von Bildung für nachhaltige Entwicklung in Deutschland. Opladen, Berlin, Toronto: Barbara Budrich Verlag, S. 117-188.

Rauschenbach, T./Leu, H. R./Lingenauber, S./Mack, W./Schilling, M./Schneider, K./ Züchner, I. (2004): Non-formale und informelle Bildung im Kindes- und Jugendalter. Konzeptionelle Grundlagen für einen nationalen Bildungsbericht. Bonn: BMBF.

Singer-Brodowski, M. (2018): Verankerung von Bildung für nachhaltige Entwicklung in der Frühkindlichen Bildung. In: Brock, A./de Haan, G./ Etzkorn, N./SingerBrodowski, M. (Hrsg.) Wegmarken zur Transformation. Nationales Monitoring 
von Bildung für nachhaltige Entwicklung in Deutschland. Opladen, Berlin, Toronto: Barbara Budrich Verlag, S. 35-65.

Singer-Brodowski, M./Etzkorn, N./Grapentin-Rimek, T. (Hrsg.) (2019): Pfade der Transformation. Die Diffusion von Bildung für nachhaltige Entwicklung in Deutschland. Opladen, Berlin, Toronto: Barbara Budrich.

Temenos, C./McCann, E. (2012): The local politics of policy mobility. Learning, persuasion, and the production of a municipal sustainability fix. In: Environ. Plann. A 44(6): 1389-1406.

UNECE (United Nations Economic and Social Council) (2007): Indicators for ESD Progress Report on the Work of the Expert Group. https://www.unece.org/fileadmin/DAM/env/documents/2006/ece/cep/ac.13/ece.c ep.ac.13.2006.5.e.pdf [Zugriff: 30.04 .2018 ].

UNESCO (2014): Global Monitoring and Evaluation Report, Shaping the Future We Want-UN Decade of Education for Sustainable Development (2005-2014). Paris: UNESCO.

UNESCO (2014): UNESCO Roadmap zur Umsetzung des Weltaktionsprogramms „Bildung für nachhaltige Entwicklung“. Bonn: UNESCO.

van Poeck, K./Vandenabeele, J./Bruyninckx, H. (2013): Taking stock of the UN Decade of education for sustainable development. The policy-making process in Flanders. In: Environmental Education Research 20(5): 695-717. 



\title{
5 Kompetenzen für eine Nachhaltige Entwicklung - konzeptionelle Präzisierung der Nachhaltigkeitskompetenz über den Leistungsanspruch
}

\author{
Corinne Ruesch Schweizer
}

\subsection{Einleitung}

Eine Antwort auf die Frage, wie Hochschulbildung auf die Herausforderung einer Nachhaltigen Entwicklung reagieren kann, ist die Förderung der Kompetenz für eine Nachhaltige Entwicklung (UNESCO 2017). Es liegen verschiedene Vorschläge dazu vor, wie die zu fördernde Nachhaltigkeitskompetenz modelliert werden kann (vgl. hierzu Barth 2015). Um von solchen Kompetenzmodellen zur konkreten Gestaltung von Studienangeboten zu gelangen, die zum Erwerb der Nachhaltigkeitskompetenz beitragen sollen, ist es jedoch ein großer Schritt.

Eine solche kompetenzorientierte Studienganggestaltung setzt voraus, dass ein Kompetenzprofil entwickelt wird, auf dessen Grundlage präzise formuliert werden kann, was Studierende nach dem Abschluss einer Lerneinheit in der Lage sein sollten zu tun (vgl. Schaper et al. 2012). In der Forschung zur Hochschulbildung für eine Nachhaltige Entwicklung (HBNE) werden verschiedene Heuristiken vorgeschlagen, anhand derer solche Kompetenzprofile generiert werden können (z.B. Wieck et al. 2016; Sipos et al. 2008). In der Hochschulpraxis zeigt sich jedoch, dass solche Heuristiken nicht einfach angewandt werden (können), sondern dass Entscheidungen für die Integration von HBNE kontextbezogen getroffen werden, da in jeder Hochschule andere Rahmenbedingungen vorhanden sind (vgl. Ruesch et al. 2018). Damit sind in sich kohärente Heuristiken nur bedingt hilfreich; vielmehr bedarf es einer Entscheidungsgrundlage, auf der ein auf die spezifischen Rahmenbedingungen einer Hochschule abgestimmtes Kompetenzprofil für ein Studienangebot herausgearbeitet werden kann.

Vergleichbar mit der Entwicklung eines Kompetenzprofils schlagen Euler und Bauer-Klebl (2009) mit Blick auf die Sozialkompetenz - die wie die Nachhaltigkeitskompetenz als Schlüsselkompetenz konzeptualisiert wird vor, zunächst zu bestimmen, wie die Kompetenz aus einer didaktischen Er- 
kenntnisperspektive zu präziseren ist. Dies wird vorgeschlagen, um zu verhindern, dass eklektizistisch die für den spezifischen Anwendungskontext passenden Elemente der postulierten Heuristiken ausgewählt werden, und um eine kohärente Grundlage für die Bestimmung der Ziele eines Studienangebotes zu ermöglichen.

Dieser Argumentation folgend zielt dieser Beitrag darauf, zu erörtern, welche Entscheidungsgrundlage durch eine Präzisierung der Nachhaltigkeitskompetenz zu schaffen ist, damit diese begründete Entscheidungen für die didaktische Gestaltung eines Studienangebots ermöglicht. Dazu wird zunächst der Frage nachgegangen, wie die Präzisierung der Nachhaltigkeitskompetenz aus einer didaktischen Erkenntnisperspektive konzeptualisiert werden kann. Dabei wird die Aufmerksamkeit auf die Rolle des mit dem Kompetenzbegriff genuin verbundenen Leistungsanspruchs gerichtet. Auf diesen Überlegungen aufbauend wird im dritten Kapitel danach gefragt, welche Befunde aus der Forschung zur Hochschulbildung für eine Nachhaltige Entwicklung (HBNE-Forschung) als Entscheidungsgrundlage für die Präzisierung des Leistungsanspruchs dienen können. Abschließend werden die sich aus diesen Überlegungen ergebenden Konsequenzen für die HBNEPraxis und HBNE-Forschung zusammengefasst und weitergedacht.

\subsection{Präzisierung der Nachhaltigkeitskompetenz für die Hochschulbildung}

Für die Konzeptualisierung der Nachhaltigkeitskompetenz wird im Forschungskontext der HBNE in der Regel auf das Konzept der Schlüsselkompetenzen zurückgegriffen (vgl. z.B. Rieckmann 2010; Wiek et al. 2011; Barth 2015). Da gerade Schlüsselkompetenzen sperrig zu präzisieren sind (vgl. z.B. Schaeper/Briedis 2004), lohnt es sich die Konzeptualisierung der Präzisierung ausgehend vom Kompetenzbegriff zu betrachten. Entsprechend wird im Folgenden zunächst aufgezeigt, wie die Präzisierung von Kompetenzen für die Gestaltung von Studienangeboten und Lernprozessen im Kompetenzdiskurs konzeptualisiert wird. Daraus werden anschließend Konsequenzen für die Konzeptualisierung der Präzisierung der Nachhaltigkeitskompetenz gezogen.

\subsubsection{Kompetenzen und deren Präzisierung}

Der Kompetenzbegriff wird im pädagogischen und psychologischen Kontext - insbesondere im deutschsprachigen Raum - im Rückgriff auf Weinert (2001) konzeptualisiert (vgl. Lang-Wojtasik/Scheunpflug 2005): Er steht für 
ein komplexes Bündel an erlernbaren internen Dispositionen - wie Fähigkeiten, Wissen, Bereitschaften etc. - eines Individuums, das funktional für die Bewältigung von Situationen ist (z.B. Weinert 2001; Maag Merki 2009; Rychen 2001; Hartig/Klieme 2006; Erpenbeck/Rosenstiel 2007; Brand et al. 2005; Schaper et al. 2012). Damit umfasst der Kompetenzbegriff nicht nur interne Dispositionen, sondern ist genuin mit einem Leistungsanspruch - also der Bewältigung von Situationen, Aufgaben- oder Problemstellungen - verbunden (Winther 2010; Euler/Bauer-Klebl 2008).

Womit für die Einlösung des Leistungsanspruchs umgegangen werden muss, das heißt, den Anforderungen, die dafür zu bewältigen sind, kommt eine strukturierende Funktion für die Kompetenzen zu (Rychen 2001; Hartig/Klieme 2006). Damit hat der Leistungsanspruch für den Kompetenzbegriff eine zentrale Funktion und grenzt diesen beispielsweise vom ebenfalls auf Dispositionen bezogenen Intelligenzbegriff ab (Hartig/Klieme 2006).

Um den Kompetenzbegriff für die Bildung fruchtbar zu machen, ist dieser zunächst auf einen Gegenstandsbereich mit einem bestimmten Leistungsanspruch zu beziehen, beispielsweise auf den Gegenstandsbereich mathematischer Inhalte und Prinzipien, der mit dem Leistungsanspruch verbunden ist, Aufgaben zu bewältigen, die eine Anwendung dieser mathematischen Inhalte und Prinzipien erfordern (vgl. z.B. Köller 2009). Um den Kompetenzbegriff als Zielgröße für Bildungsangebote und Lernprozesse nutzbar zu machen, ist der jeweilige Leistungsanspruch aber nicht nur zu bestimmen, sondern auch zu präzisieren - das heißt, zu benennen, was die zu bewältigenden Anforderungen sind (Euler/Bauer-Klebl 2006). Dies erst ermöglicht, differenzierter $\mathrm{zu}$ bestimmen, welches Bündel an internen Dispositionen erforderlich ist, um dem Leistungsanspruch gerecht zu werden (Hartig/Klieme 2006). Im Folgenden wird näher auf die Präzisierung des Leistungsanspruchs eingegangen.

Durch welche zu bewältigenden Anforderungen ein Leistungsanspruch präzisiert wird, lässt sich nicht logisch aus diesem deduzieren, sondern erfordert begründete Entscheide darüber, womit umgegangen werden muss, um den Leistungsanspruch einzulösen (Euler/Bauer-Klebl 2006). Solche begründeten Entscheide erfordern eine Entscheidungsgrundlage. Dies können deskriptive oder normative Prämissen sein, die über empirische oder theoretische Zugänge oder aber über Plausibilitätsüberlegungen gewonnen werden (vgl. z.B. Euler/Bauer-Klebl 2009; Maag Merki 2009).

Die Begründung, welche zu bewältigenden Anforderungen bedeutsam sind, um einen Leistungsanspruch einzulösen, erfolgt aus unterschiedlichen Perspektiven, abhängig von der Art des Leistungsanspruchs. Dies lässt sich im Kompetenzdiskurs bei verschiedenen Kompetenzansätzen beobachten:

Fachbezogene Kompetenzen, die sich insbesondere im kognitionstheoretischen Kompetenzansatz - wie er beispielsweise im Rahmen der Entwicklung von Bildungsstandards zur Anwendung kommt (z.B. Köller 2009) - zeigen, sind mit dem Leistungsanspruch verbunden, Aufgaben zu bewältigen, die die 
Anwendung bestimmter fachbezogener Inhalte und Prinzipien erfordern. Entsprechend werden hier die zu bewältigenden Anforderungen mit Blick auf die anzuwendenden fachlichen Inhalte und Prinzipien bestimmt (vgl. z.B. Hartig/Klieme 2006).

Handlungskompetenzen, wie sie insbesondere im berufsbildungstheoretischen Ansatz postuliert werden, sind mit dem Leistungsanspruch verbunden, Handlungen in einem bestimmten Handlungsfeld selbstgesteuert zu planen, auszuführen und zu überprüfen. Entsprechend werden die zu bewältigenden Anforderungen mit Blick auf die in einem handlungsfeldspezifischen Bedingungsgefüge $\mathrm{zu}$ zeigenden Handlungen bestimmt (vgl. z.B. Sloane/Dilger 2005; Winther/Klotz 2014).

Wertbezogene Kompetenzen, die sich insbesondere im Diskurs zu Schlüsselkompetenzen zeigen, sind mit dem Leistungsanspruch verbunden, einen individuellen oder gesellschaftlichen Wert, d.h. einen Sachverhalt dem Wert zugeschrieben wird, in unterschiedlichen Situationen des Lebens zu realisieren bzw. dessen Realisierung anzustreben. Entsprechend werden die zu bewältigenden Anforderungen mit Blick auf die Realisation eines bestimmten Wertes in vielfältigen Lebenssituationen - wie familiäre, arbeitsbezogene, politische etc. Situationen (vgl. Schaeper/Briedis 2004) - bestimmt (vgl. Gilomen et al. 2001; Rychen/Salganik 2003).

Ein weiterer Punkt, der im Zusammenhang mit der Präzisierung von Leistungsansprüchen diskutiert wird, ist der zu wählende Abstraktionsgrad bei der Formulierung der zu bewältigenden Anforderungen (vgl. Weinert 2001; Euler/Bauer-Klebl 2006). Während auf einem hohen Abstraktionsniveau die $\mathrm{zu}$ bewältigenden Anforderungen unterbestimmt bleiben und entsprechend wenig fruchtbar für die Gestaltung von Lernprozessen sind, droht bei einer zu großen Nähe zu den konkret zu bewältigenden Anforderungen eine unüberschaubare Vielfalt, die aufgrund ihrer fehlenden übergeordneten Sinnstruktur ebenso wertlos für die Praxis sind.

Ist der Leistungsanspruch präzisiert, gilt es zu bestimmen, welches Bündel an internen Dispositionen zur Bewältigung der Anforderungen erforderlich ist. Es kann also festgehalten werden, dass der präzisierte Leistungsanspruch die Basis für die Bestimmung der in einem Studienangebot zu erwerbenden internen Dispositionen bildet. Somit kann der Leistungsanspruch als das entscheidende Moment für die Präzisierung von Kompetenzen betrachtet werden. Im Folgenden wird nur auf die Präzisierung des Leistungsanspruchs eingegangen, auch wenn die Bestimmung der zu erwerbenden internen Dispositionen für die Gestaltung eines Studienangebots natürlich ebenso wichtig ist. 


\subsubsection{Präzisierung des Leistungsanspruchs der Nachhaltigkeitskompetenz}

Nachhaltigkeitskompetenz lässt sich als wertbezogene Kompetenz verstehen (vgl. z.B. Rieckmann 2012), da sie mit dem Leistungsanspruch verbunden ist, den gesellschaftlichen Wert der Nachhaltigen Entwicklung in vielfältigen Situationen zu realisieren. Nachhaltige Entwicklung ist eine Idee, die international auf politischem Weg definiert wurde, und wird von den Vereinten Nationen als eine „Entwicklung, die die Bedürfnisse der Gegenwart befriedigt, ohne zu riskieren, daß künftige Generationen ihre eigenen Bedürfnisse nicht befriedigen können“ (Hauff 1987, S. 46) verstanden. An der Weltumweltkonferenz in Rio 1992 wurde diese politische Idee als internationales Leitbild verankert (vgl. z.B. Di Giulio 2004; Amelung et al. 2008; Michelsen/ Adomßent 2014). Damit wurde Nachhaltige Entwicklung international - und darauffolgend auch in einzelnen Staaten - als gesellschaftlicher Wert anerkannt, dessen Realisierung alle Handlungsfelder und Lebensbereiche betrifft.

Als wertbezogene Kompetenz ist die Nachhaltigkeitskompetenz, wie im vorangehenden Kapitel dargelegt, durch $\mathrm{zu}$ bewältigende Anforderungen strukturiert, die mit Blick auf die Realisation des Wertes, also einer Nachhaltigen Entwicklung, in unterschiedlichsten Lebenssituationen von Bedeutung sind.

Im Diskurs der Nachhaltigkeitskompetenz wird konstatiert, dass es schwierig ist, diese zu präzisieren (z.B. Sterling et al. 2017). Dies kann zum einen darauf zurückgeführt werden, dass eine Nachhaltige Entwicklung kein konkretes Ziel, sondern eine regulative Idee ist (vgl. Hirsch Hadorn/Brun 2007), die den angestrebten Zustand lediglich abstrakt beschreibt und damit unterbestimmt bleibt. Die Realisation einer Nachhaltigen Entwicklung bedarf einer Konkretisierung dieser regulativen Idee durch die Formulierung konkreter Ziele, wie sie zum Beispiel in der Agenda 21 oder den Sustainable Development Goals (SDGs) zu finden sind. Solche konkreten Ziele werden in einem bestimmten historisch-kulturellen Kontext formuliert und haben damit eine begrenzte Gültigkeit (vgl. Di Giulio 2004, 2006). In diesem Beitrag wird jedoch nicht auf Kompetenzen, die zur Erreichung solcher konkreten Ziele in einem bestimmten historisch-kulturellen Kontext erforderlich sind, fokussiert, sondern auf die Realisierung des Wertes der Nachhaltigen Entwicklung, was auch die Konkretisierung Nachhaltiger Entwicklung für den jeweiligen historisch-kulturellen Kontext miteinschließt. ${ }^{1}$

1 Vgl. die Diskurse zur Unterscheidung von spezifischen Kompetenzen für eine Nachhaltige Entwicklung und Kompetenzen, um nachhaltigkeitsbezogene Ziele zu erreichen (Di Giulio 2006), von Education for Sustainable Development (ESD)1 und ESD2 (Vare/Scott 2007) oder von instrumenteller und emanzipatorischer HBNE (Barth 2015). 
Mit Blick auf die regulative Idee einer Nachhaltigen Entwicklung ist festzuhalten, dass sich in der Gegenwart nie abschließend beurteilen lässt, ob der Wert der Nachhaltigen Entwicklung ${ }^{2}$ realisiert ist, da nur Annahmen hinsichtlich dessen getroffen werden können, ob es für die zukünftigen Generationen möglich sein wird, ihre Bedürfnisse zu befriedigen (vgl. dazu auch de Haan et al. 2008). So vage und diffus, wie teilweise konstatiert wird, ist der Begriff der Nachhaltigkeit jedoch nicht. Verschiedene Ansätze der Bildung für eine Nachhaltige Entwicklung zeigen, dass es möglich ist, auf einer zwar abstrakten, aber dennoch präzisen Definition aufzubauen, wann davon gesprochen werden darf, dass eine Aktivität oder ein Ziel als nachhaltig bezeichnet werden kann. Dies lässt sich an folgenden beiden Beispielen zeigen:

De Haan et al. (2008) präzisieren die Nachhaltigkeitskompetenz, die sie als Gestaltungskompetenz konzeptualisieren, durch die Verknüpfung zweier Prinzipien, die sie aus der Brundtland-Definition ableiten: ,planungsrationale“3 Nachhaltigkeit und (,synchrone“ und „diachrone“) Gerechtigkeit. Diese beiden Prinzipien erlauben, wenn sie gleichzeitig angewendet werden, davon auszugehen, dass der Wert der Nachhaltigen Entwicklung mit einer Aktivität realisiert wird. Bertschy et al. (2007) legen ihrem Ansatz für Kompetenzen für eine Nachhaltige Entwicklung inhaltsbezogene und prozessbezogene Ansprüche an Zielsetzungen - in einer Analyse der Dokumente der Vereinten Nationen herausgearbeitet (vgl. dazu Di Giulio 2004) - zugrunde, die erlauben davon auszugehen, dass mit Zielsetzungen, die unter diesen und in Hinblick auf diese Ansprüche formuliert wurden, der Wert der Nachhaltigkeit realisiert wird. Mit diesen beiden Ansätzen sind alternative Kriterien angesprochen, zu bestimmen, wann eine Aktivität bzw. eine Zielsetzung als nachhaltig gelten darf. Im Diskurs zu BNE und insbesondere im NachhaltigkeitsDiskurs liegen weitere Kriterien vor, auf die hier nicht eingegangen werden kann und soll. Vielmehr soll hier darauf verwiesen werden, dass solche Ansätze vorhanden sind, auf deren Grundlage der Leistungsanspruch der Nachhaltigkeitskompetenz präzisiert werden kann.

Zum anderen kann die konstatierte Schwierigkeit, Nachhaltigkeitskompetenz zu präzisieren, auch darauf zurückgeführt werden, dass sich der Leis-

2 Vgl. hierzu die Unterscheidung zwischen ,Nachhaltigkeit als Wert` und ,Werte im Zusammenhang mit Nachhaltigkeit‘ (Ruesch Schweizer/Di Giulio 2016).

3 Unter ,planungsrationaler“ Nachhaltigkeit verstehen de Haan et al. (2008) die Herausbildung einer Präferenzenordnung mit der Handlungszwecken eine bestimmte Präferenz zugewiesen wird, insbesondere auch mit Blick darauf, welche Präferenz einem Zweck gegenwärtig und welche zukünftig zugeschrieben wird, und die Entwicklung von Strategien, die erlauben die Befriedigung gegenwärtiger und zukünftiger Präferenzen in ein ausgewogenes Verhältnis zu bringen. Kurz: „Eine Handlung soll nur dann nachhaltig heißen, wenn sie die Bereitstellung von Ressourcen für das künftige Erreichen der (gegenwärtig) übergeordneten Zwecke mindestens nicht gefährdet" (de Haan et al. 2008, S. 6; Hervorhebung im Original). 
tungsanspruch wertbezogener Kompetenzen nicht auf ein konkretes Handlungsfeld und auch nicht auf einen abgrenzbaren Wissens- und Methodenkorpus bezieht, sondern auf eine unüberschaubare Vielfalt von Lebenssituationen in denen der Wert der Nachhaltigen Entwicklung realisiert werden soll. Die Realisation des Wertes ist in lebensweltlichen Situationen nicht der einzige Leistungsanspruch, vielmehr zeichnen sich lebensweltliche Situationen durch verschiedene Leistungsansprüche aus, die gleichzeitig einzulösen sind und sich gegenseitig beeinflussen.

Den Wert der Nachhaltigen Entwicklung zu realisieren, ist entsprechend nur ein Leistungsanspruch unter vielen und lässt sich nicht ungeachtet anderer Leistungsansprüche in einer Lebenssituation realisieren. Zur Präzisierung des nachhaltigkeitsbezogenen Leistungsanspruchs ist es entsprechend erforderlich, nicht nur zu bestimmen, wann der Wert der Nachhaltigen Entwicklung als realisiert gelten darf, sondern auch, was bedeutsam ist, um diesen in komplexen Lebenssituationen - das heißt in solchen, in denen verschiedene interdependente Leistungsansprüche vorhanden sind - zu realisieren. Dabei ist letzteres nicht unabhängig von ersterem.

Die Annahme darüber, wann der Wert der Nachhaltigen Entwicklung als realisiert gelten darf, beeinflusst unter welcher Perspektive Lebenssituationen wahrgenommen werden. Das heißt, sie beeinflussen, welche Situationen und damit auch welche interagierenden Leistungsansprüche in den Vordergrund gerückt werden und damit auch, welche Anforderungen als besonders bedeutsam zu bewältigen betrachtet werden, um den nachhaltigkeitsbezogenen Leistungsanspruch einzulösen. So werden bei de Haan et al. (2008), aufgrund der beiden anzuwendenden Prinzipien, zu bewältigende Anforderungen mit Blick auf Dilemma- und Entscheidungsprozesse hervorgehoben. Demgegenüber werden bei Bertschy et al. (2007), aufgrund der Ansprüche an die Zielsetzungen, zu bewältigende Anforderungen mit Blick auf ,gesellschaftliche Aushandlungs- und Mitgestaltungsprozesse“ (Bertschy et al. 2007, S. 44) hervorgehoben.

Wenn also verschiedene Kriterien zu Perspektiven führen, mit denen unterschiedliche Anforderungen als bedeutsam zu bewältigen hervorgehoben werden, stellt sich die Frage, ob es gerechtfertigt ist, Nachhaltigkeitskompetenz aus nur einer Perspektive heraus zu präzisieren; umso mehr als sich auch der wissenschaftliche Nachhaltigkeitsdiskurs durch eine Diversität der Kriterien auszeichnet. Entsprechend gibt es Stimmen, die auch für die Präzisierung der Nachhaltigkeitskompetenz - insbesondere im Kontext einer HBNE diese Diversität der Kriterien begrüßen (Wals/Jickling 2002) und festhalten, dass ,instead of ignoring this diversity, we explicitly take it as our point of departure when defining key competences for sustainable development“ (Kraker 2007, S. 106). Diese Diversität der Kriterien bei der Präzisierung des nachhaltigkeitsbezogenen Leistungsanspruchs zu berücksichtigen, heißt zum einen, die Diversität der Kriterien als Vielfalt von Zugängen zur Präzisierung 
des nachhaltigkeitsbezogenen Leistungsanspruch einzubeziehen. Zum andern kann aber auch die Diversität der Kriterien selbst, eine in nachhaltigkeitsbezogenen Situationen zu bewältigende Anforderung sein (vgl. dazu auch Wals/ Jickling 2002).

Zusammenfassend kann festgehalten werden, dass der Leistungsanspruch der Nachhaltigkeitskompetenz die Realisierung des Wertes der Nachhaltigen Entwicklung in unterschiedlichsten Lebenssituationen ist. Bei der Präzisierung - das heißt, bei der Bestimmung, welche Anforderungen bedeutsam sind zu bewältigen, um diesen Leistungsanspruch einzulösen - gilt es, so konnte aufgezeigt werden, zum einen zu beachten, dass es vielfältige Kriterien gibt, zu bestimmen, wann der Wert als realisiert gelten darf. Zum andern gilt es, den Interdependenzen des nachhaltigkeitsbezogenen Leistungsanspruchs mit andern Leistungsansprüchen in unterschiedlichen Lebenssituationen Aufmerksamkeit zu schenken.

\subsection{Erkenntnisse aus der HBNE-Forschung für die Präzisierung des nachhaltigkeitsbezogenen Leistungsanspruchs}

Zunächst muss konstatiert werden, dass nur eine begrenzte Zahl von Studien, sich mit der Präzisierung der Nachhaltigkeitskompetenz befasst (vgl. Barth/Rieckmann 2016). Hinzu kommt, dass ein großer Teil der vorhandenen Studien auf die Bestimmung von relevanten internen Dispositionen fokussiert. Diese stärker auf die internen Dispositionen als auf die Präzisierung des Leistungsanspruchs gerichtete Aufmerksamkeit führt dazu, dass in vielen Studien nur am Rande Aussagen über nachhaltigkeitsbezogene Leistungsansprüche an Hochschulabgängerinnen und -abgänger gemacht werden.

So lässt sich in der HBNE-Forschung zwar eine breite Palette von nachhaltigkeitsbezogenen Leistungsansprüchen finden, hingegen liegen nur wenige empirische Befunde und theoretische Ansätze dazu vor, die präzisieren, welche Anforderungen von Hochschulabgängerinnen und -abgänger zu bewältigen sind, um diese Leistungsansprüche zu einzulösen.

Die Studien von Willard et al. (2010) und Hanning et al. (2012) geben Aufschluss darüber, im Zusammenhang mit welchen Aufgabenbereichen und Themen nachhaltigkeitsbezogene Anforderungen zu bewältigen sind, um den nachhaltigkeitsbezogenen Leistungsanspruch einzulösen. Damit liegen Erkenntnisse dazu vor, mit Blick auf welche Themen Leistungsansprüche vorhanden sind und mit welchen aufgabenbezogenen Leistungsansprüchen der nachhaltigkeitsbezogene Leistungsanspruch interagiert. Offen bleibt hingegen, welche nachhaltigkeitsbezogenen Anforderungen daraus erwachsen. 
Solche nachhaltigkeitsbezogenen Anforderungen werden in qualitativen Studien herausgearbeitet. So beschreiben beispielsweise Perez Salgado et al. (2018) Machtverhältnisse, die typisch für beschäftigungspraktische Situationen von Nachhaltigkeitsfachleuten sind und zu Konflikten führen können. Solche Anforderungen zeigen auf, welche Anforderungen aufgrund der Interaktion des nachhaltigkeitsbezogenen Leistungsanspruchs mit einem bestimmten beschäftigungspraktischen Leistungsanspruchs als bedeutsam wahrgenommen werden. Ein umfassender Zugang zu den Anforderungen eines ganzen Tätigkeitsfeldes wird in der Studie von Wesselink und Wals (2011) gewählt. Hier werden in der Beschreibung von Beispielsituationen Herausforderungen identifiziert, auf deren Basis erforderliche interne Dispositionen bestimmt werden. Offen bleibt in diesen Studien, wie sich die herausgearbeiteten Anforderungen in der übergeordneten Sinnstruktur verorten lassen, die ermöglicht, die Bedeutsamkeit der beschriebenen Anforderungen für die Realisierung des Wertes der Nachhaltigen Entwicklung hinsichtlich der Interdependenz mit den in der Studie fokussierten Lebenssituationen und hinsichtlich eines oder mehreren Kriterien, wann der Wert der Nachhaltigen Entwicklung als realisiert gelten darf, zu beurteilen.

Auf solche übergeordneten Sinnstrukturen referenzieren Kompetenzmodelle, die durch ein Modell, eine Theorie oder ein Konzept den nachhaltigkeitsbezogenen Leistungsanspruch präzisieren. So referenzieren beispielsweise Nikisch und Müller-Christ (2013) in ihrem Kompetenzmodell zum nachhaltigen Wirtschaften auf das Kriterium, dass der Wert der Nachhaltigen Entwicklung dann als realisiert gelten darf, wenn der Verbrauch jeglicher Arten von materiellen und immateriellen Ressourcen und deren Nachschub ausgeglichen gestaltet wird. Und begründen vor diesem Hintergrund die bedeutsamen Anforderungen in Situationen, in denen dieser nachhaltigkeitsbezogene Leistungsanspruch mit einem ökonomischen Leistungsanspruch zusammentrifft.

Nicht auf ein bestimmtes Kriterium, wann Nachhaltige Entwicklung als realisiert gelten darf, fokussiert das Rahmenmodell, das Wiek et al (2011) ihrer Metaanalyse von nachhaltigkeitsbezogenen Kompetenzmodellen als Leistungsanspruch zugrunde legen. In diesem Modell lässt sich ein stärker prozessbezogener Leistungsanspruch - nicht-nachhaltige Zustände in (zukünftig) nachhaltige Zustände zu transformieren - erkennen, mit dem nicht auf ein konkretes Kriterium referenziert wird, wann der Wert der Nachhaltigen Entwicklung als realisiert gelten darf, sondern diese Bestimmung als zu bewältigende Anforderung deklariert. Dies ermöglicht eine übergeordnete Sinnstruktur, die nicht von einem bestimmten Kriterium ausgeht, sondern eine, mit der der Diversität der Kriterien Rechnung getragen werden kann. Eine Sinnstruktur hinsichtlich der Frage, mit welchen anderen Leistungsansprüchen die Realisation des Wertes der Nachhaltigen Entwicklung in konkreten Lebenssituationen interagiert, umfasst das Modell nicht. Der für dieses 
Rahmenmodell gewählte Abstraktionsgrad ermöglicht einerseits die mit der Metaanalyse anstrebte Integration von unterschiedlichen Kompetenzmodellen, anderseits bleibt aus der didaktischen Erkenntnisperspektive die Präzisierung des Leistungsanspruchs unterbestimmt. Dies bildet einen Gegenpol zu den sehr konkreten, aber strukturlosen qualitativen Beschreibungen von Anforderungen, die weiter oben beschrieben wurden.

Dieser Blick in die HBNE-Forschung zeigt, dass die wenigen bisher vorliegenden Erkenntnisse zur Präzisierung des nachhaltigkeitsbezogenen Leistungsanspruchs, die Anforderungen, die für die Einlösung des Leistungsanspruchs bedeutsam sind, aus einer didaktischen Erkenntnisperspektive entweder zu wenig präzise beschreiben oder zu wenig explizit machen, aus der Perspektive welches Nachhaltigkeitskriteriums und für welches Feld von Lebenssituationen die Anforderungen bedeutsam sind.

\subsection{Konsequenzen für die HBNE-Praxis und HBNE- Forschung}

Diese Überlegungen zur Präzisierung der Nachhaltigkeitskompetenzen machen deutlich, dass hinter der für die Studienangebotsgestaltung zentralen Frage, was die Studierenden nach Abschluss eines Studienangebotes in der Lage sein sollen zu tun, mehr steht als die Entscheidung, welche internen Dispositionen gefördert werden sollen. Vielmehr ist mit dieser Entscheidung die Entscheidung verbunden, welche Anforderungen die Absolventinnen und Absolventen mit den erworbenen Dispositionen bewältigen können sollen. Das heißt, es muss entschieden werden, welche Anforderungen relevant sind. Diese Relevanz lässt sich nicht abschließend durch empirische Befunde oder theoretische Modelle bestimmen; vielmehr sind Entscheidungen darüber erforderlich, vor dem Hintergrund welcher Zugänge zu Nachhaltiger Entwicklung und mit Blick auf welche Felder bzw. welche Arten von Lebenssituationen entschieden werden soll, welche Anforderungen bedeutsam sind.

Hingegen können empirische Befunde und theoretische Modelle fundierte Hinweise darauf geben, welche Anforderungen mit Blick auf welche Kriterien, wann der Wert der Nachhaltigen Entwicklung als realisiert gelten darf, und für welche Lebenssituationen sie bedeutsam sind. Solche Erkenntnisse liegen aber erst in Ansätzen vor. Damit die HBNE-Forschung die kompetenzorientierte Gestaltung von Studiengängen unterstützen kann, sollte die Forschung nicht nur drauf gerichtet werden, welche internen Dispositionen in den Hochschulen gefördert werden sollen, sondern vielmehr auch darauf, welche Leistung von Hochschulabgängerinnen und -abgänger gefordert ist, wenn sie den Wert den Nachhaltigen Entwicklung in konkreten Lebenssituationen realisieren wollen oder sollen. Wie aus den Überlegungen zur Präzisie- 
rung der Nachhaltigkeitskompetenz hervorgeht, können insbesondere Erkenntnisse eine gute Entscheidungsgrundlage für die Gestaltung von Studienangeboten bieten, die den Zugang zu Nachhaltiger Entwicklung sowie die Lebenssituationen, für die die Anforderungen bedeutsam sind, ausweisen und sich dabei auf ein mittleres Abstraktionsniveau von Anforderungen beziehen.

Mit einem mittleren Abstraktionsniveau ist gemeint, dass Anforderungen auf der einen Seite so verallgemeinert beschrieben sind, dass sie von den situationsspezifischen Anforderungen abstrahieren und die zentralen Aspekte für die Bestimmung der internen Dispositionen benennen. Und auf der anderen Seite aber auch so konkret beschrieben sind, dass die Verallgemeinerung nachvollziehbar ist und die beschriebenen Anforderungen als Bezugspunkte für die didaktische Gestaltung von Studienangeboten dienen können. Um möglichst exemplarische nachhaltigkeitsbezogene Anforderungen für die Gestaltung von Studienangeboten wählen zu können, sind zudem Erkenntnisse dazu von Bedeutung, wie ähnlich sich nachhaltigkeitsbezogene Anforderungen über verschiedene Typen von Lebenssituationen hinweg sind.

\section{Literatur}

Amelung, N./Mayer-Scholl, B./Schäfer, M./Weber, J. (2008): Nachhaltige Entwicklung als Leitbild für Gesellschaft und Forschung: Einstieg in Nachhaltige Entwicklung. In: Amelung, N./Mayer-Scholl, B./Schäfer, M./Weber, J. (Hrsg.): Einstieg in Nachhaltige Entwicklung. Frankfurt a. M: Lang, S. 5-20.

Barth, M. (2015): Implementing sustainability in higher education: learning in an age of transformation. New York: Routledge.

Barth, M./Rieckmann, M. (2016): State of the art in research on higher education for sustainable development. In: Barth, M./Michelsen, G./Rieckmann, M./Thomas, I. (Hrsg.): Routledge handbook of higher education for sustainable development. London: Routledge, S. 100-113.

Bertschy, F./Gingins, F./Künzli, C./Di Giulio, A./Kaufmann-Hayoz, R. (2007): Bildung für Nachhaltige Entwicklung in der obligatorischen Schule. Schlussbericht zum Expertenmandat der EDK: „Nachhaltige Entwicklung in der Grundschulausbildung - Begriffsklärung und Adaption“. Januar 2007. Bern: Schweizerische Konferenz der kantonalen Erziehungsdirektoren. https://edudoc.ch/record/24373/files/BNE_Schlussbericht_2007_d.pdf [Zugriff: 06.08.2018].

Brand, W./Hofmeister, W./Tramm, T. (2005): Auf dem Weg zu einem Kompetenzstufenmodell für die berufliche Bildung - Erfahrungen aus dem Projekt ULME. In: bwp@ 8:1-21.

de Haan, G./Kamp, G./Lerch, A./Martignon, L./Müller-Christ, G./Nutzinger, H. G./Wütscher, F. (2008): Nachhaltigkeit und Gerechtigkeit: Grundlagen und schulpraktische Konsequenzen. Berlin: Springer. 
de Kraker, J. (2007): Competences and competence-based learning for sustainable development. In: de Kraker, J./Lansu, A./van Dam-Mieras, R. (Hrsg.): Crossing boundaries: Innovative learning for sustainable development in higher education. Frankfurt: VAS, S. 103-114.

Di Giulio, A. (2004): Die Idee der Nachhaltigkeit im Verständnis der Vereinten Nationen: Anspruch, Bedeutung und Schwierigkeiten. Münster: Lit.

Di Giulio, A. (2006): Education for sustainable development - What does it mean and what should students learn? In: Adomssent, M./Godemann, J./Leicht, A./Busch, A. (Hrsg.): Higher education for sustainability. new challenges from a global perspective. Frankfurt: VAS, S. 60-66.

Erpenbeck, J./von Rosenstiel, L. (2007): Handbuch Kompetenzmessung: Erkennen, verstehen und bewerten von Kompetenzen in der betrieblichen, pädagogischen und psychologischen Praxis. Stuttgart: Schäffer-Poeschel Verlag.

Euler, D./Bauer-Klebl, A. (2006): ,Sozialkompetenzen' als didaktisches Konstrukt. Theoretische Fundierungen und Konsequenzen für die Curriculumentwicklung. St. Gallen: Institut für Wirtschaftspädagogik der Universität St. Gallen. http://www3.iwp.unisg.ch/org/iwp/bbf-soko.nsf/SysWebRessources/Euler-

Bauer+-+Sozialkompetenzen+als+didaktisches+Konstrukt.pdf. [Zugriff: 27.02.2014].

Euler, D./Bauer-Klebl, A. (2009): Bestimmung von Sozialkompetenzen als didaktisches Konstrukt. In: Euler, D. (Hrsg.): Sozialkompetenzen in der beruflichen Bildung. Bern: Haupt, S. 21-59.

Gilomen, H./Rychen, D. S./Salganik, L. H. (2001): Concluding Remarks. In: Rychen, D. S./Salganik, L. H. (Hrsg.): Defining and Selecting Key Competencies. Hogrefe \& Huber, S. 247-251.

Hanning, A./Priem, A. A./Lundqvist, U./Svanström, M. (2012): Are we educating engineers for sustainability? Comparison between obtained competences and Swedish industry's needs. In: International Journal of Sustainability in Higher Education 13(3): 305-320.

Hartig, J./Klieme, E. (2006): Kompetenz und Kompetenzdiagnostik. In: Schweizer, K. (Hrsg.): Leistung und Leistungsdiagnostik. Berlin, Heidelberg: Springer, S. 127143.

Hauff, V. (Hrsg.) (1987): Unsere gemeinsame Zukunft. Der Brundtland-Bericht der Weltkommission für Umwelt und Entwicklung. Greven: Eggenkamp Verlag.

Hirsch Hadorn, G./Brun, G. (2007): Ethische Probleme nachhaltiger Entwicklung. In: Schweizerische Akademie der Geistes- und Sozialwissenschaften (Hrsg.): Nachhaltige Entwicklung. Nachhaltigkeitsforschung. Perspektiven der Sozial- und Geisteswissenschaften. Bern: Schweizerische Akademie der Geistes- und Sozialwissenschaften, S. 235-253.

Köller, O. (2018): Bildungsstandards. In: Rudolf, T./Bernhard, S. (Hrsg.): Handbuch Bildungsforschung. Wiesbaden: Springer, S. 625-648.

Lang-Wojtasik, G./Scheunpflug, A. (2005): Kompetenzen Globalen Lernens. In: Zeitschrift für internationale Bildungsforschung und Entwicklungspädagogik (ZEP) 28: 2-7.

Maag Merki, K. (2009): Kompetenz. In: Andresen, S./Casale, R./Gabriel, T./Horlacher, R./Larcher Klee, S./Oelkers, J. (Hrsg.): Handwörterbuch Erziehungswissenschaft. Weinheim: Beltz, S. 492-506. 
Michelsen, G./Adomßent, M. (2014): Nachhaltige Entwicklung: Hintergründe und Zusammenhänge. In: Heinrichs, H./Michelsen, G. (Hrsg.): Nachhaltigkeitswissenschaften. Berlin, Heidelberg: Springer Spektrum, S. 1-59.

Nikisch, G./Müller-Christ, G. (2013): Sustainable Leadership: Was müssen Führungskräfte können um nachhaltigere Entscheidungen zu treffen? In: Keuper, F./Neumann, F. (Hrsg.): Sustainability Management. Berlin: Logos, S. 147-171.

Perez Salgado, F./Abbott, D./Wilson, G. (2018): Dimensions of professional competences for interventions towards sustainability. In: Sustainability Science 13(1): 163-177.

Rieckmann, M. (2010): Die globale Perspektive der Bildung für eine nachhaltige Entwicklung: eine europäisch-lateinamerikanische Studie zu Schlüsselkompetenzen für Denken und Handeln in der Weltgesellschaft. Berlin: BWV Berliner Wissenschafts-Verlag.

Ruesch Schweizer, C./Di Giulio, A./Burkhardt-Holm, P. (2018): Qualifikationsziele von Lehrangeboten zu Nachhaltigkeit. Ein Blick in die Hochschulpraxis in Deutschland und der Schweiz. In: Leal Filho, W. (Hrsg.): Nachhaltigkeit in der Lehre. Theorie und Praxis der Nachhaltigkeit. Berlin, Heidelberg: Springer Spektrum, S. 257-276.

Ruesch Schweizer, C./Di Giulio, A. (2016): Nachhaltigkeitswerte: Eine Kultur der Nachhaltigkeit? Sekundäranalyse der Daten aus der StabeNE-Erhebung 2008. In: SOCIENCE, Journal of Science-Society Interfaces 1(1): 91-104.

Rychen, D. S. (2001): Introduction. In: Rychen, D. S./Salganik, L. H. (Hrsg.): Defining and Selecting Key Competencies. Hogrefe \& Huber, S. 1-15.

Rychen, D. S./Salganik, L. H. (2003): A holistic model of competence. In: Rychen, D. S./Salganik, L. H. (Hrsg.): Key competencies for a successful life and a wellfunctioning society. Cambridge, Göttingen: Hogrefe \& Huber Publishers, S. 4162.

Schaeper, H./Briedis, K. (2004): Kompetenzen von Hochschulabsolventinnen und Hochschulabsolventen, berufliche Anforderungen und Folgerungen für die Hochschulreform.

Hannover: http://www.forschungsnetzwerk.at/downloadpub/kompetenzen $\% 20$ von $\% 20$ hochs chulabsolventInnen.pdf [Zugriff: 06.08.2018].

Schaper, N./Reis, O./Wildt, J. (2012): Fachgutachten zur Kompetenzorientierung in Studium und Lehre. Bonn. https://www.hrk-nexus.de/ leadmin/redaktion/hrknexus/07Downloads/07-02Publikationen/fachgutachten_kompetenzorientierung.pdf [Zugriff: 30.03.2017].

Sipos, Y./Battisti, B./Grimm, K. (2008): Achieving transformative sustainability learning: engaging head, hands and heart. In: International Journal of Sustainability in Higher Education 9(1): 68-86.

Sloane, P. F. E./Dilger, B. (2005): The Competence Clash - Dilemmata bei der Übertragung des Konzepts der nationalen Bildungsstandards auf die berufliche Bildung. In: Berufs-und Wirtschaftspädagogik online 8: 1-32.

Sterling, S./Glasser, H./Rieckmann, M./Warwick, P. (2017): 'More than scaling up': a critical and practical inquiry into operationalizing sustainability competencies. In: Blaze Corcoran, P./Weakland, J. P./Wals, A. E. J. (Hrsg.): Envisioning futures for environmental and sustainability education. Wageningen: Wageningen Academic Publishers, S. 681-700. 
UNESCO (2017): Guidelines on sustainability science in research and education. http://unesdoc.unesco.org/images/0026/002606/260600e.pdf 06.08.2018].

Vare, P./Scott, W. (2007): Learning for a change: Exploring the relationship between education and sustainable development. In: Journal of Education for Sustainable Development 1(2): 191-198.

Wals, A. E. J./Jickling, B. (2002): Sustainability in higher education: From doublethink and newspeak to critical thinking and meaningful learning. In: International Journal of Sustainability in Higher Education 3(3): 221-232.

Weinert, F. E. (2001): Concept of Competence: A Conceptual Clarification. In: Rychen, D. S./Salganik, L. H. (Hrsg.): Defining and Selecting Key Competencies. Hogrefe \& Huber, S. 45-65.

Wesselink, R./Wals, A. E. J. (2011): Developing competence profiles for educators in environmental education organisations in the Netherlands. In: Environmental Education Research 17(1): 69-90.

Wiek, A./Bernstein, M./Foley, R./Cohen, M./Kuzdas, C./Kay, B./Withycombe Keeler, L. (2016): Operationalising competencies in higher education for sustainable development. In: Barth, M./Michelsen, G./Rieckmann, M./Thomas, I. (Hrsg.): Routledge handbook of higher education for sustainable development. London: Routledge, S. 241-260.

Wiek, A./Withycombe, L./Redman, C. L. (2011): Key competencies in sustainability: a reference framework for academic program development. In: Sustainability Science 6(2): 203-218.

Willard, M./Wiedmeyer, C./Flint, W. R./Weedon, J. S./Woodward, R./Feldman, I./Edwards, M. (2010): The sustainability professional: 2010 competency survey report. ISSP - International Society of Sustainability Professionals. https://sustainabilityprofessionals.org/sustainability-professional-2010competency-survey-report [Zugriff: 06.08.2018].

Winther, E. (2010): Kompetenzmessung in der beruflichen Bildung. Bielefeld: W. Bertelsmann Verlag.

Winther, E./Klotz, V. K. (2014): Spezifika der beruflichen Kompetenzdiagnostik Inhalte und Methodologie. In: Zeitschrift für Erziehungswissenschaft 17(1): 9-32. 


\title{
6 Nahtstellen nachhaltigen globalen Lernens - Philosophieren als (neue) Aufgabe von Unterricht
}

\author{
Lydia Kater-Wettstädt
}

\subsection{Ausgangspunkt - Schule und Unterricht in der Globalisierung}

Im Rahmen der Globalisierung und den damit verbundenen weltweiten Veränderungen des Klimas, der natürlichen Ressourcen, des Bevölkerungswachstums oder der Kommunikation wird das „Menschzeitalter“ ausgerufen (Crutzen/Stoerner 2000), das die Gestaltung der weltlichen Abläufe durch den Menschen und sein Handeln gesteuert und maßgeblich beeinflusst versteht. Ihm wird damit aber auch eine entsprechende Verantwortung zugewiesen den Erhalt der Welt, wie wir sie kennen, zu gewährleisten (Steffen/Persson et al. 2011). So wurden 2015 die Sustainable Development Goals in der UN-Mitgliederversammlung verabschiedet, deren Bearbeitung in der Verantwortung der internationalen Staatengemeinschaft verankert wird; so wird auch die deutsche Strategie zur Implementation der Agenda 2030 (BMZ/BMUB 2015) mit dem Zitat Ban-Ki Moons kontextuiert, der prophezeit, dass wir gegebenenfalls die letzte Generation sein könnten, „,...) die die Chance hat, unseren Planeten zu retten "“1. Die nachhaltige Beeinflussung der weltweiten Entwicklungen werden mit einer Art "planetary stewardship“ (Steffen/Persson 2011) gerahmt und so bearbeitbar und mit Handlungsverantwortung versehen.

Gleichzeitig bringt die globale Gesellschaft bzw. die Weltgesellschaft für den eher nahbereichsorientierten Menschen nicht unbedeutende Herausforderungen mit sich: Kulturen und Identitäten sind vielfältig und diffus, Selbstund Standortbestimmungen zeichnen sich mit der Beteiligung an unterschiedlichen „globalisierten Systemen“ mit einer Vielzahl an realen oder digitalen Akteuren durch Pluralität und Diversität aus. Dies wird sowohl im Nahbereich durch die unterschiedlichen Menschen mit ihren vielfältigen Hinter-

1 Siehe unter http://www.bmz.de/de/ministerium/ziele/2030_agenda/index.html [Zugriff 25.04.2018]. 
gründen, Sprachen oder Religionen erfahrbar, als auch im täglichen direkten oder indirekten Konsum globaler Güter und Medien, in der Vernetzung mit Individuen überall auf der Welt und die mit diesen Möglichkeiten verbundene nahezu unbegrenzte Verfügbarkeit von Informationen (vgl. Beck 2004). Die weltweite Vernetzung ist jetzt Bestandteil der alltäglichen Erfahrungswelt der Kinder und Jugendlichen (vgl. Villányi et al. 2007) und strukturiert ihre Weltsicht. Die Welt als blauer Planet mit den unzähligen Entscheidungsund Handlungsoptionen ist immer schon Teil ihrer Imagination, immer schon in ihren Köpfen und eröffnet einen Möglichkeitsraum, der abhängig von sozioökonomischen Voraussetzungen nahezu unbegrenzt erscheint und in seiner Komplexität erfasst sein will. Die Frage, welchen Schokoriegel man gerne essen oder welches Handy man als nächstes kaufen möchte, kann man eben nur erwägen, weil der Lebensmittelmarkt international verknüpft ist. Weltgesellschaft ist damit essentieller Teil unseres Alltags im Hier und Jetzt (vgl. Sander 2018).

Was bedeutet das für den einzelnen und die Verortung von Bildungsaufgaben, für Schule und Unterricht? Eine zentrale Frage mit Blick auf eine zukunftsfähige Bildung ist, ob Schule und Unterricht lediglich kompensatorisch reagieren oder, ob sie agieren und eine aktive Selbstüberprüfung und Umgestaltung einlösen muss? Und wenn ja, wo es Ansatzpunkte für ein Umdenken und eine aktive Umgestaltung gibt, die es Kindern und Jugendlichen ermöglichen sich in einer Weltgesellschaft kritisch-reflexiv zu verorten und aktiv gestaltend mitzuwirken? Dass Veränderungen in der unterrichtlichen Gestaltung und inhaltlichen Ausrichtung notwendig erscheinen, bildet sich z.B. durch explizite Bildungskonzepte, die der Globalisierungstatsache und der Gestaltungsverantwortung des Menschen Rechnung tragen, wie dem Globalen Lernen (z.B. Scheunpflug/Schröck 2002; Asbrand/Scheunpflug 2014) oder der Bildung für nachhaltige Entwicklung (z.B. de Haan/Harenberg 1999; Künzli/Bertschy 2008) ab, die zunehmend Eingang in bildungspolitische Rahmenvorgaben finden (s. z.B. Niedersächsisches Kultusministerium 2017a, 2017b). „Global competence“ ist zudem der ergänzende Testschwerpunkt neben Rechnen und Lesen in der PISA-Studie 2018 (OECD 2018). Aber auch der Diskurs um den Umgang mit der Vielfalt in den Klassenzimmern (z.B. Eisenmann/Grimm 2011; Prengel 2006) wird im Zuge spürbar zunehmender Migrationsbewegungen, inklusiver Beschulung, „digitaler natives“ immer mehr Aufmerksamkeit geschenkt, weil deutlich wird, dass das bestehende System in seiner Form und Funktionalität in vielerlei Aspekten in Frage steht. Dieser Beitrag nähert sich dieser Frage auf der Ebene von Unterricht an und stellt auf der Basis empirischer Befunde zur Auseinandersetzung von Jugendlichen mit globalen Fragestellungen, die nur überblicksartig dargestellt werden, Überlegungen zu einer Veränderung der Unterrichts- und damit auch der Schulpraxis an. 


\subsection{Umgangsweisen mit globalen Fragestellungen im Unterricht $^{2}$}

Im Rahmen einer qualitativ-rekonstruktiven Studie wurden etwa 150 Unterrichtsstunden an insgesamt vier Gymnasien und zwei Integrierten Gesamtschulen videographiert. Es wurden jeweils eine Unterrichtseinheit in unterschiedlichen Fächern (Biologie, Gesellschaftslehre, Sozialkunde, Werte und Normen) begleitet. Der Unterricht fand in 10. - 12. Jahrgangsstufen statt und behandelte - laut Selbstauskunft der Lehrkräfte - Themen des Lernbereichs Globale Entwicklung (z.B. Schadstoffe in Textilien, Fleischkonsum und Regenwaldzerstörung). Die aufgezeichneten Unterrichtseinheiten wiesen hinsichtlich ihrer didaktisch-methodischen Gestaltung eine große Vielfalt auf. In der Auswertung der Unterrichtsdiskurse zu globalen Fragestellungen kristallisierten sich drei Kompetenzbereiche heraus, die relevant im Umgang mit diesen wurden: der Umgang mit Nicht-Wissen, mit Perspektivität und mit Handlungsaufforderungen. Für die folgenden Ausführungen werden die didaktisch-methodischen Rahmenbedingungen und der Umgang mit NichtWissen und mit Handlungsaufforderungen näher beleuchtet. Der Umgang mit Wissen bzw. Nicht-Wissen stellt nämlich genau die Schlüsselstelle bzw. die Antinomie dar, an der sich die Funktionsbestimmung von Schule orientiert: die Vermittlung von (schulisch-relevantem) Wissen (vgl. z.B. Kolbe/Reh et al. 2008, S. 131). Handlungsaufforderungen wiederum bilden das Kernanliegen von Bildungskonzepten für eine nachhaltige Entwicklung im Sinne einer „Handlungsfähigkeit im globalen Wandel“ (BMZ/KMK 2016, S. 95) und einer „Es-muss-sich-was-ändern-Maxime“ ab.

Das empirische Material wurde mit Hilfe der dokumentarischen Methode analysiert. Für dieses qualitativ-rekonstruktive methodische Verfahren ist im Anschluss an die Wissenssoziologie Karl Mannheims (1980) die Unterscheidung zwischen konjunktivem und kommunikativem Wissen zentral; die dokumentarische Methode ermöglicht einen empirischen Zugang zu beiden Wissensebenen (vgl. zum Folgenden ausführlich Bohnsack 2007, S. 134ff.). Das konjunktive Wissen ist anders als das kommunikative Wissen, implizites, atheoretisches Wissen und gilt als handlungsleitend. Das konjunktive Wissen oder auch Habitus wird in der Handlungspraxis angeeignet und strukturiert diese (vgl. Bohnsack 2009, S. 15ff.). Der Habitus der Erforschten lässt sich sowohl in der Analyse der verbalen als auch nonverbalen Kommunikation im Unterricht rekonstruieren (zur Bild- und Videointerpretation vgl. ebd.).

In dem Projekt wurden kürzere Unterrichtssequenzen vergleichend analysiert. Im Rahmen der komparativen Analyse (vgl. Bohnsack 2007, S. 141ff.) 
können die rekonstruierten Wissensstrukturen und der Habitus auf die Bedingungen ihrer Genese zurückgeführt werden, „konjunktive Erfahrungsräume“ (Mannheim 1980, S. 229), in denen sie hergestellt und angeeignet werden in diesem Fall unterschiedliche Lehr-Lernarrangements.

\subsubsection{Die methodisch-didaktischen Rahmenbedingungen}

Für die erhobenen Unterrichtsstunden konnten zwei unterschiedliche Lehrmodi identifiziert werden, die sich aus dem Zusammenspiel und -wirken der jeweilig umgesetzten didaktisch-methodischen Unterrichtsformen und der eingesetzten Unterrichtsmaterialien bestimmten, basierend auf dem habituellen, impliziten Wissen und Handeln der Lehrkräfte.

Zum einen konnte ein Modus der Themenvermittlung und zum anderen einer der Themen-Ko-Konstruktion identifiziert werden, die sich im Hinblick auf die Adressierung der Lernenden, die Rahmung des Lernprozesses, die Prozessgestaltung selbst und die Beteiligung der Schülerinnen und Schüler am Prozess und damit einhergehend die Rolle der Lehrkraft, die sie dabei selbst übernimmt, unterschieden. Der Modus der Themenvermittlung zeichnet sich insgesamt durch ein lehrerzentriertes Vorgehen aus. Der Lernprozess wird als Be- bzw. Abhandlung eines Themas gerahmt, in dem die Lernenden die Nicht-Wissenden sind und die Lehrkraft die Steuerung übernimmt. Entsprechend der geringen Verantwortungsabgabe ist die Eigenständigkeit der Schülerinnen und Schüler eher gering (siehe Tab. 1).

Im Modus der Themen-Ko-Konstruktion lässt sich demgegenüber eine Rahmung des Lernprozesses als sukzessive oder kumulative Erschließung eines Themas beobachten, die die Schülerinnen und Schüler mit ihrem je spezifischen Vorwissen Rechnung trägt, indem z.B. Schülerfragen an das Thema generiert werden sollen, die beantwortet werden müssen, um ein „Experte“ zu werden und eine Aufgabe bewältigen zu können. Die Rolle der Lehrkraft ist darin eher eine organisatorische, die eine höhere Eigenständigkeit der Lernenden und Verantwortungsübernahme für den eigenen Lernprozess einfordert.

Die unterschiedlichen Umgangsweisen der Schülerinnen und Schüler innerhalb der drei Kompetenzbereiche Umgang mit Nicht-Wissen, mit Perspektivität und mit Handlungsaufforderungen können mit den rekonstruierten Lehrmodi in Verbindung gebracht und ihre Genese erklärt werden. 
Tabelle 1: Übersicht über die rekonstruierten Lehrmodi (eigene Darstellung)

\begin{tabular}{|l|l|l|}
\hline Charakteristika & Themenvermittlung & $\begin{array}{l}\text { Themen-Ko- } \\
\text { Konstruktion }\end{array}$ \\
\hline Rahmung Lernprozess & Behandlung des Themas & $\begin{array}{l}\text { Kumulative } \\
\text { Erschließung }\end{array}$ \\
\hline $\begin{array}{l}\text { Adressierung der } \\
\text { Lernenden }\end{array}$ & Nicht-Wissende & Mit Vorwissen \\
\hline Rolle der Lehrkraft & Steuerung & Organisation \\
\hline Prozessgestaltung & $\begin{array}{l}\text { Geringe Verantwortungs- } \\
\text { abgabe }\end{array}$ & $\begin{array}{l}\text { Mehr Verantwortungs- } \\
\text { abgabe }\end{array}$ \\
\hline $\begin{array}{l}\text { Eigenständigkeit der Schüle- } \\
\text { rinnen und Schüler }\end{array}$ & Gering & Hoch \\
\hline
\end{tabular}

\subsubsection{Der Umgang mit Nicht-Wissen}

Bei den Schülerinnen und Schülern in dieser Studie ließen sich zwei Orientierungen im Umgang mit Nicht-Wissen beobachten: Nicht-Wissen wird dabei entweder als ein Defizit betrachtet, das es zu kompensieren gilt, oder als Potential angesehen, von dem ausgehend, Themen erschlossen werden.

Schülerinnen und Schüler in eher geschlossenen, lehrerzentrierten LehrLernsettings wiesen dabei die erstere Umgangsform auf. Nicht-Wissen wird hier als ein Defizit betrachtet. Diese Rahmung ist charakterisiert durch ein dichotomes Verständnis von Wissen und Nicht-Wissen. Das eine schließt das andere aus und beides ist eindeutig voneinander unterscheidbar. Die Jugendlichen sind auf der Suche nach ,richtigen“ Lösungen als sicherem Wissen. Wissen kann und muss das Nicht-Wissen aufheben bzw. kann es ersetzen. Die beobachteten Schülerinnen und Schüler können die eigene mit ihrem Nicht-Wissen verbundene Unsicherheit nicht konstruktiv bearbeiten. Sie erwarten die Auflösung durch die Lehrkraft, die die entsprechend richtigen Lösungen hat. Wissenserwerb ist in diesem Rahmen keine Entwicklung von weniger zu mehr Wissen oder Können, sondern die Einzelinformationen als Lösungen zählen als Ergebnis. Das vermittelte Wissen bildet in der Folge eine ,richtige“ Realität ab, die unhinterfragt übernommen wird.

In der Orientierung der Schülerinnen und Schüler, die Nicht-Wissen als Potential konstruieren, zeigt sich hingegen ein kumulatives Verständnis des Wissenserwerbs als ein sich fortsetzender Prozess von weniger zu mehr Wissen. Diese Orientierung konnte in eher offenen Lehr-Lernsettings beobachtet werden, in denen die Lehrkraft vor allem eine organisierende Rolle einnimmt und die Schülerinnen und Schüler mehr Verantwortung für ihren Lernprozess übernehmen. Der Wissenserwerb dient in diesem Rahmen einer Vertiefung von Interessen oder einer Entwicklung von Expertise und ist somit letztlich nicht abschließbar. Es steht die Frage des „Mehr-Wissen-Könnens“ und des benötigten Wissens zur Bewältigung einer Aufgabe bzw. zur Lösung eines 
Problems im Vordergrund und nicht die Frage nach dem, was nicht gewusst wird. Die Schülerinnen und Schüler in den beobachteten Sequenzen können konstruktiv mit Nicht-Wissen und Unsicherheit umgehen und bearbeiten die gestellten Aufgaben, indem sie vor allem an vorhandenes Wissen anknüpfen und sich in einen teils bis überwiegend selbstgesteuerten Prozess der Themenerschließung begeben.

Gemeinsam ist den Schülerinnen und Schüler in den untersuchten LehrLernsettings, dass erkenntnistheoretische Fragen, die Reichweite und die Möglichkeiten des Wissen-Könnens, dessen Qualität und die Begrenzungen oder Gesteuertheit des eigenen Wissens, z.B. durch Suchalgorithmen im Internet, nicht reflektiert werden.

\subsubsection{Der Umgang mit Handlungsaufforderungen}

Im Hinblick auf den Kompetenzbereich Umgang mit Handlungsaufforderungen zeigen sich in den Rekonstruktionen drei unterschiedliche Umgangsformen: zum einen eine Reproduktion von Handlungsaufforderungen sowie eine Reflexion des Nicht-Handelns und zum anderen eine Reflexion von Handlungsaufforderungen im politischen Modus.

Der Modus der Reproduktion war in den geschlossenen, durch die Lehrkräfte stark durchstrukturierten Lehr-Lernsettings, die wenig Eigenständigkeit oder Verantwortung von den Lernenden für das eigene Lernen einforderten, zu beobachten. Hier werden Handlungsaufforderungen als ein theoretisches Thema bearbeitet. Die gestellten Aufforderungen zu einer Veränderung des Verhaltens werden von den Schülerinnen und Schülern nicht als Aufforderung verstanden. Das Thema Handeln wird für sie nicht in der Qualität einer Aufforderung relevant und die über das Handeln vermittelten Informationen lediglich wiedergegeben. Die Aufforderungen enthalten moralischethische Setzungen, die durch die Schülerinnen und Schüler referiert, aber nicht in einen Zusammenhang mit dem eigenen Leben und Handeln gebracht werden.

Auch die Form der Auseinandersetzung als eine Reflexion des NichtHandelns ist in den Lehr-Lernsettings zu beobachten, die durch den Lehrmodus der Themenvermittlung strukturiert sind. Die Schülerinnen und Schüler, die über ihr Nicht-Handeln reflektieren, weisen die an sie herangetragenen Aufforderungen explizit ab. Die Thematisierung der Handlungsaufforderungen in moralischen Kategorien, wie „Schuld“ und „Verantwortung“, evozieren eine Ablehnung der Schülerinnen und Schüler (vgl. auch Wettstädt/Asbrand 2014). Auf der Ebene des kommunikativen Wissens werden zwar die thematisierten Missstände als Anlässe zum Handeln anerkannt, dieses Wissen wird aber nicht handlungsleitend. Im Unterschied zum reproduzierenden Habitus wird der Aufforderungscharakter zwar wirksam, aber es 
werden entsprechende Entschuldigungs- und Legitimationsstrategien generiert, die das eigene Nicht-Handeln im Sinne der moralisch-ethischen Kriterien rechtfertigen. Verantwortung wird zudem an andere Akteure oder die Allgemeinheit delegiert.

In einem offenen Lehr-Lernsetting, das eine mehr eigenständige Auseinandersetzung mit dem Thema einforderte, konnte eine Abwägung von Handlungsaufforderungen im politischen Modus beobachtet werden. Bei diesen Schülerinnen und Schülern lag der Fokus auf der Exploration von Handlungsmöglichkeiten auf einer gesellschaftlich-politischen Handlungsebene. Dabei sehen sie politische Macht als notwendige Bedingung für ein wirksames Handeln an. Handlungsoptionen werden hier nicht grundsätzlich abgelehnt oder für unmöglich erklärt, aber für den individuellen Handlungsraum auch nicht erwogen.

Gemeinsam ist allen Formen des Umgangs mit Handlungsaufforderungen, dass die individuelle Handlungsebene nicht exploriert wird. Die Ansprüche an das individuelle außerschulische Handeln und die darin enthaltenen moralisch-ethischen Maßstäbe werden von den Schülerinnen und Schülern überwiegend negiert oder nicht zum Gegenstand der Auseinandersetzungen. Nur in der Reflexion von Handlungsoptionen als politischem Thema scheint eine zukünftige, potentielle Handlungsmöglichkeit auf.

Tabelle 2: Übersicht über die Umgangsformen in unterschiedlichen Lehrsettings (eigene Darstellung)

\begin{tabular}{|c|c|c|}
\hline $\begin{array}{l}\text { Kompetenz- } \\
\text { bereiche }\end{array}$ & $\begin{array}{l}\text { Umgang mit } \\
\text { Nicht-Wissen }\end{array}$ & $\begin{array}{l}\text { Umgang mit } \\
\text { Handlungsaufforderungen }\end{array}$ \\
\hline \multirow{2}{*}{$\begin{array}{l}\text { Themen- } \\
\text { Vermittlung }\end{array}$} & \multirow{2}{*}{$\begin{array}{l}\text { Umgang mit Nicht-Wissen } \\
\text { als Kompensation }\end{array}$} & Reproduktion \\
\hline & & Reflexion von Nicht-Handeln \\
\hline $\begin{array}{l}\text { Themen-Ko- } \\
\text { Konstruktion }\end{array}$ & $\begin{array}{l}\text { Umgang mit Nicht-Wissen } \\
\text { als Potential }\end{array}$ & $\begin{array}{l}\text { Reflexion im } \\
\text { politischen Modus }\end{array}$ \\
\hline
\end{tabular}

In der Auswertung dieses Unterrichts zeigt sich demnach, dass es in den Lehr-Lernarrangements häufig um die Vermittlung von „richtigem“ Wissen, und um die potentielle Lösung bestehender Probleme ging. Auffällig ist, dass die Schülerinnen und Schüler im Umgang mit globalen Fragestellungen und den damit verbundenen Herausforderungen eher dazu tendieren, die Anforderungen $\mathrm{zu}$ reproduzieren, z.B. vorgegebene Handlungsaufforderungen. Gleichwohl weist ein ko-konstruierender Lehrmodus Möglichkeiten auf, Kompetenzen über eine Reproduktion und Abweisung hinweg zu entwickeln.

Insgesamt wird deutlich, dass z.B. Quellen von Informationen, damit auch ihre Perspektivität, die Begrenztheit des eigenen Wissens oder die Reichweite von Handlungsoptionen nicht in Frage gestellt bzw. in den Fokus gerückt 
werden: Ein kritisches Nachdenken über die Informationen, die rezipiert werden oder die eigene Rolle in diesem System wird nicht exploriert. So werden eindimensionale Informationen über Menschen und Länder als Abbild der Realität betrachtet und ein einfaches Relationsverhältnis eingeübt, was in Anbetracht globaler Transformationen kritisch zu betrachten ist.

\subsection{Nahtstellen - Philosophieren als Ansatzpunkt}

In der Zusammenschau der Ergebnisse lassen sich damit vor dem Hintergrund der globalen und pluralisierten Lebenswelten, in denen Wissen und Informationen mehr als je zuvor vorhanden $\operatorname{sind}^{3}$, zwei offene Nahtstellen ausmachen, die auch in Bildungskonzepten, gerade einer Bildung für nachhaltige Entwicklung, nur bedingt explizit Eingang gefunden haben (z.B. BMZ/KMK 2016; de Haan 2008): so zum einen die Reflexion von Erkenntnis und Wissen, Standort- bzw. Kulturgebundenheit, Begrenzung und Steuerung von Erkenntnisprozessen und Instrumentarien und zum anderen die Ausführung der Handlung selbst und die Reflexion derselben sowie der Zusammenhang zwischen Wissen und Handeln als BNE immanentes Spannungsverhältnis (vgl. dazu auch Kruse 2013). Obwohl diese Aspekte häufig in den Bildungskonzepten angedeutet werden, vor allem im Sinne einer Reflexion über Werte und Normen (vgl. z.B. Öhman 2007), scheint sich in der beobachteten pädagogischen Praxis eine Dramaturgie vom Wissen zum Handeln eingeschrieben zu haben (siehe aber auch z.B. BMZ/KMK 2015: Erkennen - Bewerten - Handeln, S. 95), die keinen Raum lässt für „Grundsätzliches". Die angeführten Punkte machen deutlich, dass sich daraus andere Anforderungen an Unterricht und Schule ergeben.

\subsubsection{BNE und Philosophieren}

Gerade das Grundsätzliche scheint doch der Kern einer Bildung für nachhaltige Entwicklung zu sein. So fragte Kant: „Was kann ich wissen? Was soll ich tun? Was darf ich hoffen? Was ist der Mensch?“ (vgl. Kant 1974). Unabhängig von den philosophischen Deutungsversuchen, woher die Fragen stammen (z.B. Sturma 2004, S. 267) bzw. einer genauen philosophischen Diskursverortung seiner Ethik zwischen Deontologie und Utilitarismus (dazu

3 „Das World Wide Web trägt den globalen Anspruch schon im Namen und bildet die Basis für eine Fülle von weltweit verfübaren Informations-, Kommunikations-, Kooperations- und Handelsangeboten (...)“(Sanders 2018, S. 39). 
Düsing 2004), scheinen sie doch in einer pragmatisch-inhaltlichen Übertragung die vier wichtigsten Aspekte einer BNE zu adressieren: Erkenntniskritik (Erkenntnisprozess, Grenzen, Ungewissheit, vielperspektivisches Erschließen der Dinge), Möglichkeiten des Handelns, Zukunftsbezug und Verortung des Menschen in der Welt. Auch Kants „pädagogische Grundsatzfrage“ „Wie kultiviere ich Freiheit bei dem Zwange?" adressiert nicht nur die grundsätzliche Antinomie der Pädagogik (vgl. Mikhail 2017, S. 105), sondern auch das weitergehende Anliegen einer BNE zur individuellen Gestaltung zu befähigen, aber dies eben im Einklang mit bestimmten (politisch gestalteten) Wertvorstellungen (schützenswerte Natur, ökonomische Umstrukturierung, sozial verträglich u.ä.). Diese Fragen für und über Pädagogik regen dazu an, über grundsätzliche Kategorien (Mensch, Wissen, Handeln) und Wertvorstellungen (Freiheit, Mensch-Umwelt-Natur-Verhältnis) nachzudenken und sie zum Gegenstand von Reflexion zu machen. Philosophieren in Schule und Unterricht wird hier als ein Anstoßen (ergebnis-)offener Prozesse verstanden, der die Schulung einer kritisch-reflektierten, aber konstruktiv-lösungsorientierten Haltung zum Ziel hat. ${ }^{4}$

Die Verknüpfung von BNE und Philosophie ist keine radikal neue. Philosophieren mit Kindern scheint insgesamt eine tendenziell steigende Aufmerksamkeit zu bekommen (vgl. Martens 1999; Deutsche UNESCO-Kommission 2008; Calvert/Hausberg 2011; Brüning 2015). Die Ergebnisse der vorgestellten Studie zeigen auf, dass eine tiefergehende Auseinandersetzung notwendig ist, und sie zeigen, wie nötig ein Umdenken in der pädagogischen Praxis ist, wenn Kinder und Jugendliche im schulischen Kontext darauf vorbereitet werden sollen, ihre Zukunft aktiv im Sinne einer nachhaltigen Entwicklung mitzugestalten und nicht in reproduzierende Routinen zu verfallen. „Der Ansatz des Philosophierens mit Kindern scheint geeignet, um eine auffällige Lücke in den heutigen Bildungssystemen zu schließen" (Deutsche UNESCOKommission 2008, S. 12), im Sinne einer intellektuellen und moralischethischen Förderung. Künzli, Buchs und Wüst (2015) unterstreichen, dass schon die Unterscheidung nachhaltiger und nicht-nachhaltiger Entwicklungen voraussetzt, ,moral-ethisch urteilen zu können“ (ebd., S. 115). Gleichzeitig ist eine rein methodische oder perspektivenbezogene Betrachtung zu kurz gegriffen. Philosophieren im Unterricht bedeutet dann nicht, einfach nur eine philosophische Frage aufzuwerfen oder eine moralisch-ethische Perspektive einzunehmen, sondern in Bezug auf die empirischen Rekonstruktionen wird deutlich, dass es darum gehen muss, den Lehrmodus zu verändern und Verantwortung für das inhaltliche Explorieren, gedankliche Abschreiten von Möglichkeitsräumen, das Erfühlen der Grenzen des Vorstellungsvermögens, die Orientierung im Denken (vgl. Martens 1999) abzugeben (vgl. Künzli et

4 Ähnlich dem Grundgedanken einer kritisch-konstruktiven Bildung im Sinne Klafkis (1985), der die Augaben der Allgemeinbildung entlang von Schlüsselproblemen argumentiert hat. 
al. 2015, S. 117f.). Dies adressiert den Lernenden auch nicht in einer Rolle als Nicht-Wissenden, sondern als Individuum mit eigenen Vorstellungen, Werten, Unsicherheiten und Ideen.

Das bedeutet, dass es auf der einen Seite immer noch um eine Vermittlung von Wissen gehen muss, aber es auf der anderen Seite und nicht minder wichtig vor dem Hintergrund globaler Informationsströme, darum geht, sich mit Fragen auseinanderzusetzen, auf die es keine eindeutigen und richtigen Antworten gibt, sich auf die Suche zu begeben nach Antworten, die individuell und kollektiv erst entwickelt werden müssen. Dies würde die Möglichkeit eröffnen eher eine konstruktive Haltung gegenüber Unsicherheit und Ungewissheit vor dem Hintergrund von Nicht-Wissen einzuüben, in der Werte und Normen als Orientierung angenommen und exploriert werden können. Die Lehrkraft hätte dann nicht die „richtige“ Lösung und der Lernprozess wäre eine sukzessive Annäherung an einen Gegenstand, der in plurale oder kollektive Lösungsszenarien überführt werden kann. Dies wäre zugleich eine Antwort auf die Frage, wie das Verhältnis von Freiheit und Zwang bearbeitet werden kann. Gleichzeitig bedeutet das nicht, dass eine allein logische, vernunftgeleitete, theoretisch-kognitive Auseinandersetzung dabei einzufordern ist. Dass dann die Gefahr des Theoretisierens besteht, zeigen die Umgangsformen mit Handlungsaufforderungen, die nicht in ein Verhältnis zum eigenen Leben gebracht werden können. Vielmehr geht es darüber hinaus um die Frage, ,woher wir die Kraft für langfristig sinnvolles Tun nehmen“ (Manstetten 1996, S. 291). Hier werden Spiritualität und Handeln bedeutsam. Manstetten hält sogar fest: „Die Kraft sich für das Ideal der Nachhaltigkeit einzusetzen und auf einen sozialen Konsens hinzuwirken, kommt aus dem Glauben“" (ebd., S. 295) und führt aus, dass ein allein intellektuell postulierter Glaube nicht lebt. Auch Selby (2017) macht deutlich, dass das instrumentelle Verhältnis westlicher Gesellschaften zur Natur kaum dazu beitragen oder dazu motivieren wird, sich für deren Schutz einzusetzen (vgl. ebd., S. 9) und plädiert für multisensorisches Lernen ,(...) that helps the learner engage with both spirit and soul of place“" (ebd.). So gälte es nun, dass die Menschen sich wieder stärker als Teil der Natur begreifen und den achtenden Umgang in und mit der Natur quasi zurück erlernen (vgl. Mok-Wendt 2015). Spirituelle Nuancen werden im Diskurs um BNE deutlich, die den Lernenden emotional und als handelndes, aktives Individuum in seiner Umwelt adressieren, indem Handlungsräume und Reflexionen von Motivationen eingefordert werden. Auf der Basis von Selbsterfahrungen, die Teil des Lernprozesses sind, könnte so eine tiefergehende und holistischere Auseinandersetzung mit grundsätzlichen Fragen erreicht werden. 


\subsubsection{Konsequenzen für die Praxis}

Die empirischen Ergebnisse und die damit verbundenen Herausforderungen adressieren nicht nur die Unterrichtsgestaltung als solches, sondern auch die Schule als Institution.

Neben den vielen didaktisch-methoden Ratgebern zum Philosophieren mit Kindern allgemein, die ein methodisches Repertoire anbieten (vgl. z.B. Martens 1999; Brüning 2015), ginge es vor allem darum, die Unterrichtspraxis zu öffnen und die eigene Rolle als Lehrkraft zu reflektieren. Wie adressiere ich meine Lernenden? Wie gestalte und steuere ich den Lernprozess, wo kann ich dabei Verantwortung abgeben und Räume öffnen? Dies betrifft vor allem die Ebene der Unterrichtsplanung und -durchführung. Bei diesen Reflexionsprozessen können kollegiale Beobachtung, Videoaufnahmen und Reflexionsgespräche mit Schülerinnen und Schülern oder Kolleginnen und Kollegen sehr hilfreich sein, da es sich hier meist um implizite, der Reflexion nicht immer zugängliche Prozesse handelt.

Methoden, die eine fruchtbare Verbindung von BNE und Philosophieren versprechen, sind zum einen das philosophische Gespräch selbst, das eine Konzentration auf die Gesprächskultur und den gegenseitigen Umgang miteinander sowie die kollektive Annäherung an Grundsatzfragen erlaubt. So können zentrale Fragen, wie „Was macht ein gutes, gelingendes Leben aus?“, „Was ist Gerechtigkeit?“, oder „Wem gehört die Welt?" fenden Prozess thematisiert werden.

Zum anderen sind Visionen und Szenarien ein fruchtbarer Kontext, der dem Explorieren der Zukunft unter unterschiedlichen Gesichtspunkten, wie Wahrscheinlichkeit, Wünschen oder Plausibilität, Raum gibt. Was wäre z.B., wenn ab morgen die Müllabfuhr nicht mehr käme, was wäre, wenn alle meine Wünsche morgen in Erfüllung gingen?

In diesen Fragen wird bereits deutlich, dass es dabei schnell um die Schule als Ganzes und auch die Schule in der Gemeinde, in der Gesellschaft geht. Wenn sich Lernende mit Handlungsmöglichkeiten auseinandersetzen sollen, dann kann sich Schule nur als ein experimenteller und geschützter Handlungsraum verstehen, in dem Handeln erprobt, wiederholt, überdacht und verändert werden kann. Die Delegation der Veränderungsverantwortung von Schule an die Schülerinnen und Schüler für die Zukunft und an die Privatperson, zuhause bessere Menschen zu werden und nachhaltiger zu agieren, ist problematisch. Dieser Prozess kann nur in der Schule selbst im Sinne des Whole-School-Approaches seinen Anfang nehmen (vgl. z.B. auch BMZ/KMK 2016; Hargreaves 2008; Hunt/King 2015). Das bedeutet auch,

5 Eine Teilfrage in dem Material der Bundeszentrale für politische Bildung zu Thema Philosophieren mit Kindern, s. unter http://www.bpb.de/228237/philosophieren-mit-kindern [Zugriff: 28.04.2018]. 
dass die Aktionen oder die Handlungen nicht ausschließlich als Abschluss, sondern vor allem als Teil oder Ausgangspunkt des Lernprozesses gedacht werden.

\subsection{Fazit und Ausblick}

Die Ausbildung kritischer und handlungsfähiger Individuen erscheint nunmehr als Aufgabe, die Schule im Zuge globaler Transformationen, trotz im Überfluss vorhandenen, frei zugänglichen Wissens und Kommunikationsformen unabhängig von Raum und Zeit, einen ganz eigenen Wert zuweist, der das Miteinander (und nicht Gegeneinander) stärkt: miteinander Lösungen aushandeln, Wertevielfalt sichtbar und nachvollziehbar machen, die Begrenztheit des Wissens entdecken und die Ungewissheit bearbeiten. Gleichzeitig entlastet das Philosophieren die Bildung von einer ökonomischtradierten Zweckrationalität, wenn es um prozessbezogene Kompetenzen des Abwägens, Argumentierens, gedanklichen Erprobens, aber auch der Selbsterfahrung in der Umwelt, der Natur und in der Gemeinschaft geht. Diesen Anspruch kann nur die Schule als mehr oder weniger unabhängige Institution einlösen. Erachtet man zudem eine demokratische Staatsform als erstrebenswert, ,sind problemlösungsorientierte, begriffs- und argumentbezogene Debatten und Auseinandersetzungen, die als Prozess betrachtet werden können, in dem jeder seine Meinung einem philosophischen Prüfverfahren unterwirft" (Deutsche UNESCO-Kommission 2008, S. 19) grundlegend und müssten die Schullaufbahn der zukünftigen Erwachsenen begleiten. Die empirischen Ergebnisse der vorgestellten Studie deuten darauf hin, welche Probleme Lehrerzentrierung im Unterricht mit sich bringen kann, aber auch welche Potentiale in der Öffnung des Unterrichts sowohl im Sinne des Lehrmodus, aber auch in Richtung der Schule selbst gerade vor dem Hintergrund einer Bildung für nachhaltige Entwicklung stecken. Dieser geschützte Raum ist doch eigentlich bestens dafür geeignet, Verortung in einer globalisierten Welt zu ermöglichen.

\section{Literatur}

Asbrand, B./Scheunpflug, A. (2014): Globales Lernen. In: Sander, W. (Hrsg.): Handbuch politische Bildung. Reihe Politik und Bildung. Schwalbach, Taunus: Wochenschau-Verlag, S. 401-412.

Beck, U. (2004): Was ist Globalisierung? Irrtümer des Globalismus - Antworten auf Globalisierung. Frankfurt am Main: Suhrkamp Verlag. 
BMZ (Bundesministerium für wirtschaftliche Zusammenarbeit und Entwicklung)/ BMUB (Bundesministerium für Umwelt, Naturschutz, Bau und Reaktorsicherheit) (2015): Unsere Ziele für eine lebenswerte Zukunft. Post 2015-Agenda für nachhaltige Entwicklung.

http://www.bmz.de/de/mediathek/publikationen/reihen/infobroschueren_flyer/info broschueren/Materialie258_post 2015_agenda.pdf [Zugriff: 28.04.2018].

BMZ (Bundesministerium für wirtschaftliche Zusammenarbeit und Entwicklung)/KMK (Kultusministerkonferenz) (2016): Orientierungsrahmen für den Lernbereich Globale Entwicklung im Rahmen einer Bildung für nachhaltige Entwicklung. Bonn, Berlin.

Bohnsack, R. (2009): Qualitative Bild- und Videointerpretation. Die dokumentarische Methode. Opladen \& Farmington Hills: Barbara Budrich.

Bohnsack, R. (2007): Rekonstruktive Sozialforschung. Einführung in qualitative Methoden. 6. Aufl. Opladen \& Farmington Hills: Barbara Budrich.

Brüning, B. (2015): Philosophieren mit Kindern. Eine Einführung in Theorie und Praxis. Berlin: LIT Verlag.

Calvert, K./Hausberg, A. K. (2011): PhiNa: Philosophieren mit Kindern über die Natur. Handbuch. Baltmannsweiler: Schneider Verlag Hohengehren.

Crutzen, P. J./Stoermer, E. F. (2000): The Anthropocene. In: IGBP Newsletter 41: 1718.

de Haan, G./Harenberg, D. (1999): Bildung für nachhaltige Entwicklung. Gutachten zum Programm. Materialien zur Bildungsplanung und zur Forschungsförderung. Bonn: BLK.

Deutsche UNESCO-Kommission e.V. (2008): Philosophie - eine Schule der Freiheit. Philosophieren mit Kindern weltweit und in Deutschland. http://www.unesco.de/fileadmin/medien/Dokumente/Wissenschaft/Philosophieeine-Schule-der-Freiheit.pdf [Zugriff: 25.04.2018].

Düsing, K. (2004): Kants Ethik in der Philosophie der Gegenwart. In: Heidemann, D. H./Engelhard, K. (Hrsg.): Warum Kant heute? Systematische Bedeutung und Rezeption seiner Philosophie in der Gegenwart. Berlin, New York: Walter de Gruyter, S. 231-263.

Eisenmann, M./Grimm, T. (Hrsg.) (2011): Heterogene Klassen - Differenzierung in Schule und Unterricht. Baltmannsweiler: Schneider Verlag Hohengehren.

Hargreaves, L. G. (2008): The whole-school approach to education for sustainable development: from pilot projects to systematic changes. In: Policy \& Practice: A Development Education Review 6: 69-74.

Hunt, F./King, R. P. (2015): Supporting whole school approaches to global learning: focusing learning and mapping impact.

http://discovery.ucl.ac.uk/1473867/1/franhunt2015supportingwholeschoolapproac hestogloballearning.pdf [Zugriff: 29.04.2018].

Kant, I. (1974): Kritik der reinen Vernunft. Berlin: Suhrkamp.

Kater-Wettstädt, L. (2015): Unterricht im Lernbereich Globale Entwicklung. Der Kompetenzerwerb und seine Bedingungen. Zugl.: Frankfurt (Main), Univ., Diss., 2013. Erziehungswissenschaft und Weltgesellschaft, Band 8. Münster u.a.: Waxmann. 
Klafki, W. (1985): Neue Studien zur Bildungstheorie und Didaktik. Weinheim/ Basel: Beltz Verlag.

Kolbe, F.-U./Reh, S./Fritzsche, B./Idel, T.-S./Rabenstein, K. (2008): Lernkultur: Überlegungen zu einer kulturwissenschaftlichen Grundlegung qualitativer Unterrichtsforschung. In: Zeitschrift für Erziehungswissenschaft 11(1): 125-143.

Kruse, L. (2013): Vom Handeln zum Wissen - ein Perspektivenwechsel für eine Bildung für nachhaltige Entwicklung. In: Pütz, N./Schweer, M. K. W./Logemann, N. (Hrsg.): Bildung für nachhaltige Entwicklung. Aktuelle theoretische Konzepte und Beispiele praktischer Umsetzung. Psychologie und Gesellschaft. Frankfurt, M.: Lang, S. 31-60.

Künzli David, C./Buchs, C./Wüst, L. (2015): Die Bedeutung des Philosophierens mit Kindern in einer Bildung für eine Nachhaltige Entwicklung. In: Fischer, H.J./Giest, H./Michalik, K. (Hrsg.): Bildung im und durch Sachunterricht. Probleme und Perspektiven des Sachunterrichts, Band 25. Bad Heilbrunn: Klinkhardt, Julius, S. 115-120.

Künzli David, C./Kaufmann-Hayoz, R. (2008): Bildung für eine nachhaltige Entwicklung - Konzeptionelle Grundlagen, didaktische Ausgestaltung und Umsetzung. In: Umweltpsychologie 12(2): 9-28.

Mannheim, K. (1980): Strukturen des Denkens. Frankfurt am Main: Suhrkamp.

Manstetten, R. (1996): Zukunftsfähigkeit und Zukunftswürdigkeit - Philosophische Bemerkungen zum Konzept der nachhaltigen Entwicklung. In: GAIA 5(6): 291298.

Martens, E. (1999): Philosophieren mit Kindern. Eine Einführung in die Philosophie. Stuttgart: Philipp Reclam.

Mikhail, T. (2017): Kant als Pädagoge. Einführung mit zentralen Texten. Paderborn: Ferdinand Schöningh.

Mok-Wendt, C. (2015): Philosophie und Nachhaltigkeit im Umgang mit der Natur. Versuch einer NEUEN "naturphilosophischen Argumentation" für eine gerechtere, lebensbejahende Zukunft: AV Akademikerverlag.

Niedersächsisches Kultusministerium (2017a): Kerncurriculum für die Integrierte Gesamtschule. Schuljahrgänge 5-10. Deutsch. http://www.cuvo.nibis.de/ [Zugriff: 09.04.2018].

Niedersächsisches Kultusministerium (2017b): Kerncurriculum für die Grundschule. Schuljahrgänge 1-4. Sachunterricht. http://www.cuvo.nibis.de/ [Zugriff: 09.04.2018].

OECD (2018): Preparing our youth for an inclusive and sustainable world. The OECD PISA global competence framework. PISA. http://www.oecd.org/pisa/aboutpisa/Global-competency-for-an-inclusiveworld.pdf [Zugriff: 09.04.2018].

Öhman, J. (2007): The Ethical Dimension of ESD - Navigating Between the Pitfalls of Indoctrination and Relativism. In: Björneloo, I./Nyberg, E. (Hrsg.): Drivers and Barriers for Implementing Learning for Sustainable Development in Pre-School through Upper Secondary and Teacher Education. Göteborg Workshop 27-29 March 2006, S. 43-48. 
Prengel, A. (2006): Pädagogik der Vielfalt. Verschiedenheit und Gleichberechtigung in interkultureller, feministischer und integrativer Pädagogik. Wiesbaden: VS Verlag für Sozialwissenschaften.

Sander, W. (2018): Bildung - ein kulturelles Erbe für die Weltgesellschaft. Schwalbach, Taunus: Wochenschau-Verlag.

Scheunpflug, A./Schröck, N. (2002): Globales Lernen. 2. Aufl. Stuttgart: Brot für die Welt.

Selby, D. (2017): Education for sustainable development, nature and vernacular learning. In: CEPS journal 7(1): 9-27.

Steffen, W./Persson, Å./Deutsch, L./Zalasiewicz, J./Williams, M./Richardson, K./Crumley, C./Crutzen, P./Folke, C./Gordon, L./Molina, M./Ramanathan, V./Rockström, J./Scheffer, M./Schellnhuber, H. J./Svedin, U. (2011): The anthropocene. From global change to planetary stewardship. In: Ambio 40(7): 739-761.

Sturma, D. (2004): Was ist der Mensch? Kants vierte Frage und der Übergang von der philosophischen Anthropologie zur Philosophie der Person. In: Heidemann, D. H./Engelhard, K. (Hrsg.): Warum Kant heute? Systematische Bedeutung und Rezeption seiner Philosophie in der Gegenwart. Berlin, New York: Walter de Gruyter, S. 264-285.

Villányi, D./Witte, M./Sander, U. (Hrsg.) (2007): Globale Jugend und Jugendkulturen. Aufwachsen im Zeitalter der Globalisierung. Weinheim und München: Juventa.

Wettstädt, L./Asbrand, B. (2014): Handeln in der Weltgesellschaft. Zum Umgang mit Handlungsaufforderungen im Unterricht zu Themen des Lernbereichs Globale Entwicklung. In: ZEP - Zeitschrift für internationale Bildungsforschung und Entwicklungspädagogik 37(1): 4-12. 



\title{
7 Rethinking the "Global Good" of Compulsory Schooling - Combining Young People's Education and Work for Making a Future in South-West Ethiopia
}

\author{
Sabrina Maurus
}

\subsection{Introduction}

"There is no more powerful transformative force than education - to promote human rights and dignity, to eradicate poverty and deepen sustainability, to build a better future for all, founded on equal rights and social justice, respect for cultural diversity, and international solidarity and shared responsibility, all of which are fundamental aspects of our common humanity." (Irina Bokova, Director-General of UNESCO, 2015)

Education plays a central role in discourses of development and universal human rights. However, the notion of education is mostly narrowed to schooling which has become a global phenomenon (Anderson-Levitt 2005) claiming the universal validity of serving everyone (Krätli/Dyer 2006, p. 8). Thus, schooling constitutes a "global good" which reaches beyond the scope of nation states in Africa (Bierschenk 2007). During the United Nations "Education for All" campaign (1990-2015) compulsory schooling has been expanded and the requirement to send all children to school reached former peripheries in Africa.

While in most areas of Ethiopia parents invest a lot to send their children to school, and many classrooms are overcrowded with pupils, I found newly built schools in rural areas of Hamar district in south-west Ethiopia half empty during my research in 2014 and 2015. Government officials emphasized the benefits of schooling by explaining that through schooling children can "become everything, like doctor, engineer, or pilot", whereas parents asked "Who herds the goats? Who herds the cattle?" For many years it has been informally accepted that each household sends one or two sons to school and educates the other children within the agro-pastoral household economy. The attempt to strictly implement compulsory schooling for all boys and girls fueled a violent conflict in Hamar district in 2014 and 2015, in which most schools were temporarily closed, and some destroyed. The dispute between 
Hamar people and the government addressed not only disagreements about land use in Mago national park, but also the requirements of schooling for all, particularly girls' schooling.

In this article, I examine the tensions and paradoxes which the implementation of compulsory schooling creates on a local level. Based on ethnographic fieldwork in Hamar district, ${ }^{1}$ this article discusses the implications of compulsory schooling for students' life trajectories and agro-pastoral households. My research looks at education within and outside schools, as only the contextualization of schooling reveals its locally disputed meaning (Stambach 2000).

Since "education does not exist as a 'microcosm' of society or as an autonomous institution that can change people and their worlds, (...) education is entwined with social relations and projects that shape and are shaped by people's visions of the past and future." (Stambach 2017, p. 13)

Following the notion of education as part of social relations and future making, this article illustrates how young people's education outside school contributes to the agro-pastoral economy, and how the implementation of compulsory schooling is negotiated against the background of securing a household's livelihood. This analysis reveals that the incompatibility of schooling and young people's education outside school questions the sustainability of the "global good" of compulsory schooling for dealing with contemporary challenges. ${ }^{2}$

\subsection{The "Chore Curriculum" in Agro-Pastoral Households}

Although schools have existed in Hamar district ${ }^{3}$ since the 1970 s, only a minority of children from agro-pastoral families have graduated from secondary school, college or university. In the school year 2013/14 the school enrolment ratio (GER) in Hamar district was $34.7 \%$, one of the lowest in

1 Between 2012 and 2015 I conducted 19 months of doctoral fieldwork in Ethiopia, consisting of participant observation in rural and urban areas, as well as conversations and semistructured interviews carried out in Hamar and English.

2 I am very grateful to Amy Stambach and Kevin Wamalwa for their comments on earlier drafts of this paper.

3 Hamar district is part of the semi-arid lowlands of South Omo Zone in south-west Ethiopia where mostly people from the Hamar, Bana, Bashada, Kara and Arbore ethnic groups live. "Hamar" is often used as the generic term for the Hamar, Bashada, and part of the Bana, and describes the people, their language and the geographic area (Lydall 2005). The last census from 2007 counted around 47,000 Hamar (including Bashada) and about 27,000 Bana (Central Statistical Agency 2010, p. 73-74). 
South Omo Zone (Zonal Education Office, Jinka, 23/05/2014). With a few exceptions, current schoolchildren and youth from agro-pastoral families are first-generation students, whose parents and most of their siblings are illiterate.

The livelihood of most Hamar people is built on a mixture of pastoralism and agriculture, which combines slash-and-burn cultivation of corn and sorghum, as well as breeding cattle and goats. ${ }^{4}$ Whereas adults and young children live in homesteads close to the fields, older boys and unmarried men herd cattle and goats in mobile cattle camps (Strecker 2005). Growing up in agro-pastoral homesteads, young people gradually learn to work in the fields and care for the animals. Following Lancy, this way of learning can be described as a "chore curriculum". In contrast to a "core curriculum", children learn to perform chores, which is "any task that all boys or all girls should master by a roughly agreed upon age and carry out willingly and efficiently" (Lancy 2012, p. 23-24). Comparing studies on children's work in various societies, Lancy concludes:

"The chore curriculum is remarkably successful in moving children from a state of dependency to one where they are both selfsufficient and contributors to the domestic economy." (Lancy 2012, p. 42)

In Hamar, an elder called Baldambe describes how children become smart through herding animals, learning to hunt and work, and finally growing into adult men and women (Lydall/Strecker 1979, p. 70-71). This way of learning will be illustrated below by contemporary empirical examples.

\subsubsection{Learning through Observation and Imitation}

Occasions to observe how children imitate the work of older siblings and adults are manifold in agro-pastoral homesteads. One afternoon I was sitting in front of a house, when a mother left the grinding stones for a short moment. Her daughter - around the age of two - immediately took her place. The young girl kneeled in front of the stones and although she had not yet the strength to move the stone, she imitated the movements of grinding flour by swinging her body and hip. When her mother wanted to continue grinding, she distracted the girl in order to take possession of the grinding stone again (field notes, 2014). This ethnographic vignette shows that children observe and imitate older people's work at a young age.

Another day, adults and youths were ploughing the field with oxen when younger children gathered at the side of the field. The children took two leaves, which they called oxen and connected them with sticks symbolizing a 
plough. A small flexible stick served as a whip for the oxen and the children took shifts in ploughing lines in a field of sand. At the same time, adults and youths took shifts in ploughing the field some meters away. When the young people got tired or if the oxen ran off, the adults stepped in and took over the plough (field notes, 2014). These examples of children's playful imitation of older people's work demonstrate that the work of adults does not take place separated from children, but in the same social sphere (Fortes 1938 in Lancy 2012 , p. 27-28). Shared daily life not only allows learning through observation and imitation, but children's participation also contributes to the household's economy.

\subsubsection{Young People's Contribution to Household Economies}

Young people's participation in daily activities makes an essential contribution to the food production and livelihood of households (cf. Katz 2004). Children in Hamar start chasing kids and calves at early age and thereby help to protect the fields. ${ }^{5}$ Around the age of seven, boys and girls begin to herd goats and sheep around the homestead. Around the age of ten, boys start herding cattle near the homestead and later in cattle camps. Households typically divide the work load among their members according to age and gender. Girls and women normally stay around the homestead and take care of domestic chores, such as sweeping, fetching firewood and water, grinding flour, cooking, as well as working in the fields and caring for young children and the elderly. The main task of boys and young men is to herd cattle and goats, so that at times they live with the animals in mobile cattle camps and only return to the homestead after some weeks or months (Lydall 1993). Boys and men also work in the fields.

The presence and work of children and youth is crucial for a highly specialized nomadic economy (Klute 1996), as well as a semi-mobile agropastoral economy, which distributes the labor-intensive workload among different household members. Spending days with families in the fields, I observed how women watched the fields constantly, while they dressed their hair, cooked, ground flour and made leather skirts. Whenever adults caught sight of cattle or goats approaching the fields, they ordered children to drive the animals out, and the children interrupted their play to follow the adults' instructions. Children run fast to drive the invading animals out, since they eat the growing plants and can destroy a harvest. The children's participation enables the adults to continue their work. For certain tasks and at certain seasons, the help of many people is particularly important for agro-pastoral

5 In this context, the age of children can only be estimated as it is not common to count or record biological age (cf. Abebe/Ofosu-Kusi 2016, p. 306-307). 
households. For example, during harvest time the fields are watched from sunrise to sunset, and young people help to chase away birds and monkeys who would otherwise eat the ripening sorghum. While some household members take care of the fields, others herd the goats and cattle. This mixture of younger and older people's labor allows households to diversify their economy and make a living by combining agriculture and pastoralism in a semi-arid area with unpredictable rainfall.

The work of children in Hamar resembles children's work in other farming (Polak 1998) and nomadic (Klute 1996) societies. As other studies have shown (Bourdillon et al. 2010; Bourdillon/Spittler 2012), children's work in households is not to be confused with child labor and exploitative working conditions, but constitutes a way of learning that benefits children's development and the households of which they are an integral part. In the following section, I will describe how agro-pastoral households deal with the need to educate children in the household and the requirement to send children to school.

\subsection{The Implementation of Compulsory Schooling in Hamar District}

Since the beginning of schooling in Hamar district, its implementation has created controversies. The early generation of schoolchildren remember how in the 1970s and 80s most Hamar people were not familiar with the concept of schooling. At that time, the Ethiopian government ordered local chiefs, who acted as intermediaries between the Hamar people and the government, to select children for the newly established schools (cf. Epple 2012). The local chiefs tried to persuade parents to send one of their sons to school, but not many people followed the order. Parents mistrusted not only the institution of school itself, but also the northern Amhara rulers who demanded children for school (interviews, 2014, 2015). ${ }^{6}$ Lydall describes the criteria according to which elders selected children for the early schools:

"Aike [an elder] did not send his eldest son to school because, he explained, an eldest son has indispensable, ritually prescribed roles to play in the traditional socio-economic setup. Nor did he send any of his daughters to school because that would have jeopardized their future lives as wives and mothers. (...) Boys, of course, were also crucial for the traditional economy, especially as caretakers and defenders of the herds, but an occasional boy could

6 Amhara rulers from northern Ethiopia conquered southern Ethiopia at the end of the $19^{\text {th }}$ century (Donham/James 2002 [1986]). Power relations between the northern highlands and the southern periphery are still marked by power inequalities. 
be spared to go to school in order to act later as a liaison between the Hamar and the northern neighbour." (Lydall 2010, p. 323-324)

My research shows that this principle of selecting children for school and education at home continues. Upon a man's death, his first-born son will become the household's head, inherit the herd, and, together with his mother, distribute his father's animals between himself and his younger brothers. Therefore, the most important heir is educated at home, where he learns to manage the household. Parents prefer to send second or third sons to school, as they are not so indispensable for the household.

Until recently, very few girls from Hamar families went to school. In 2014/15, out of 241 hostel students in Dimeka, only 69 were girls (Dimeka Hostel Administration, 2015). Most of these girls were in school against the will of their parents and had run away from their families to stay in the hostel and go to school. The girls' decision to start schooling as teenagers was often a way to evade an arranged marriage and led to various conflicts among kin. Most of the runaway schoolgirls do not finish school, but move in with a man in town, start a family and do not return to an agro-pastoral homestead. Therefore, households are afraid of losing their girls through schooling.

Since the learning environments of schools and agro-pastoral households constitute different social spheres, they influence the life-trajectories of young people differently. Hamar settlements are widely dispersed so that until the early 2000s most schoolchildren stayed in hostels in town. Depending on the distance, hostel students meet their rural relatives only occasionally, on market days, or when they visit the homestead at weekends or during the summer holidays. Until a high school opened in Dimeka in 2002 EC $(2009 / 10)$, students moved for secondary education to hostels which were between $100 \mathrm{~km}$ and $500 \mathrm{~km}$ away from Hamar district. ${ }^{7}$ The geographical distance between schools and homesteads becomes a social distance between schoolchildren and their natal community. While staying in a hostel, schoolchildren and youth socialize with people in town and aspire to an urban lifestyle, in which they do not learn the skills for making an agro-pastoral living.

During the era of the United Nations' "Education for All" policy, new schools were built throughout Hamar district to enable children to stay with their families while going to school. Although schools have become more easily accessible in Hamar district, and schools do not charge fees, the dropout rate is very high among agro-pastoral children. In Dimeka High School, the only high school within the district in 2013/14, children from pastoralist families constituted 47.2\% (Dimeka High School, 2014). This shows that

7 Primary school education in Ethiopia is divided into a first cycle (grades one to four) and a second cycle (grades five to eight). After graduating from high school (grades nine and ten) students are entitled to go to college. Students who perform well can attend preparatory school (grades 11 and 12) which can lead to university admission. 
although the majority of the district's population is agro-pastoral, children of town dwellers are more likely to go to high school. To improve school participation, Orkin (2012, p. 311) argues that the work performed by children which competes with schooling should be targeted through interventions. Although my findings also show that young people's participation in household work minimizes their attendance in school, I will show in the following sections that the struggles involved in combining schooling and working have both advantages and shortcomings for life-trajectories.

\subsubsection{Struggles of Combining Schooling and Working}

The difficulty of implementing compulsory schooling becomes obvious when government officials try to persuade agro-pastoral parents to send all their children to school. The parents normally respond by asking: "Who herds the cattle? Who herds the goats?" If all children and youth were to leave the homestead in the morning to go to school, adults would remain with the task of managing the diversified labor-intensive work load of an agro-pastoral household alone.

In the first part of this article, we have seen the division of labor among household members and young people's contribution to the household's livelihood. Agro-pastoral households continuously rearrange their work according to the size of the fields and herds, the seasons, and individual human conditions. When I asked young people about their reasons for leaving school, they often replied that there was no one at home to herd the goats and cattle or to plough the field. If the constitution of the household's work capacity changes, young people sometimes go back to school, even if some years have passed since they dropped out. These arrangements show that agro-pastoral households are flexible in dealing with change. However, the schooling of all young people at the same time challenges the continuity of agro-pastoral livelihoods.

When children go to school, agro-pastoral parents often refer to them as "missing". Governmental schools in Hamar district follow a national calendar, ${ }^{8}$ in which lessons normally start between eight and nine in the morning and end in the early afternoon. ${ }^{9}$ Therefore, it is not only students who stay in hostels who cannot participate in the daily life and work of agro-pastoral households, but schoolchildren who live with their families are also absent at

8 On the incompatibility of a uniform school calendar and farming needs in Gedeo in southern Ethiopia, see Abebe (2007, p. 17-18).

9 At Alternative Basic Education Centres (ABE), teachers and parents can arrange the time of the lessons independently, but my observations show that lessons were often held in the morning. 
times when important tasks need to be performed. The timing of schooling allows young people to either attend class or to herd cattle and goats. Schoolchildren can only contribute to the household's labor needs in the late afternoon and evening, when most of the work with the animals is already done, and only some work in the fields and domestic chores remain. Studies have shown that children in agricultural societies "juggle their lives between work and school" and have only limited time for homework, as their help in the household is needed before and after school (Martin 2012, p. 219). In agropastoral societies, the herding of animals needs young people during daytime, as the animals are not kept in fenced pastures. The semi-arid environment allows only extensive grazing and therefore needs many herders. Furthermore, the combination of pastoralism and agriculture demands a high number of people, for some are needed to work in the fields while others are needed to herd animals at the same time.

One way of dealing with the incompatibility of schooling and herding is that children attend class for two or three days a week, and help in the household on the other days. The alternation of schooling and working allows children to participate in both learning contexts, but the core curriculum of schools is designed for daily attendance. In contrast to regular attendance in town schools, the irregular attendance in rural schools limits learning progress and is one reason for the lower achievement of agro-pastoral children in secondary school. ${ }^{10}$

Young people who stay in hostels attend class more often and learn to speak Amharic, the official language of Ethiopia and the language of instruction. However, because they live in town for several years, hostel students do not acquire the skills and knowledge that their peers in agro-pastoral households do. A profound knowledge of how to find grazing areas within a hundred kilometres walking distance needs physical endurance, as well as a knowledge of the environment, with its plants and animals. How much children learn about agro-pastoral practices and how much they learn at school depends on the age at which they start schooling, and the distance between school and homestead. Boys who start school at a later age are more likely to have herded cattle, while most hostel students I met had never been in mobile cattle camps. Thus, both ways, schooling in town and schooling close to the homestead, have advantages and shortcomings for the student's school career and the household. Schooling also affects agro-pastoral households in the long run, as it has a transformative power on children's life paths.

10 Limitations in following the curriculum are also due to a lack of teachers, their educational background and irregular attendance in areas with limited infrastructure. Furthermore, the different languages spoken by teachers and students poses difficulties for teaching and learning. 


\subsubsection{Education and Future Transformations}

Hamar homesteads and towns constitute distinct social spheres, which shape young people's aspirations. Young people who have not been to school, or who have been to school only for a couple of years, aspire to lead an agropastoral life in the future, in which they become initiated into the Hamar community, marry a person from a specific clan, breed cattle and goats and plant fields (Maurus 2016). However, the space for an agro-pastoral economy is diminishing, due to bush encroachment, large-scale industrial farming and new infrastructure projects (Abbink et al. 2014; Abbink 1997).

Young people who leave agro-pastoral homesteads to go to school aspire to jobs outside the agro-pastoral economy and envision working in the public sector (Maurus 2016). In Hamar district, people with school education can support the household and wider community in dealing with governmental issues, as they speak the national language Amharic. They can translate in governmental institutions, like hospitals and schools, and represent the ethnic minority in the parliament. At the moment, schooled Hamar people are prioritized for employment in the local public sector (Lydall 2010, p. 329). However, with the growth in graduation rates, the competition for local government jobs is increasing.

Agricultural communities north of Hamar district have experienced mass schooling, population growth and land shortage earlier than pastoralist communities. With a growing number of people with secondary education and the decrease in public sector employees since the 1990s, the phenomenon of "educated unemployed" youth (Jeffrey 2009) preoccupies not only countries in Africa but also in Asia. "In Ethiopia, unemployment rates are actually highest among those who have completed a secondary education", argues Mains (2011, p. 4). He has documented the lives of unemployed secondary school graduates in urban Ethiopia who struggle to find jobs which they consider appropriate for their educational achievements. The results of this employment crisis can be seen in Hamar district, too. Many teachers I met were the first in their family who went to high school but could not find employment in their home areas. In search of a job, they migrated to the southern lowlands of Ethiopia which constitute a "frontier" for the highlands (Markakis 2011). How the job market will develop for Hamar school graduates and northern migrants once their number exceeds the available positions in the local public sector can only be guessed at this moment. 


\subsection{Conclusion}

Compulsory schooling has become a global phenomenon which claims to be a "global good". However, the case of Hamar district shows that in contrast to the common understanding that schooling has the transformative power to eliminate poverty, the strict implementation of compulsory schooling weakens the productivity of an agro-pastoral livelihood and leads to conflicts instead of peace. If schooling for all children is strictly implemented, it takes away household members and learning opportunities on which the agropastoral economy heavily depends. People therefore seek ways to deal with the global requirement to send all children to school, which challenges not only agro-pastoral parents in Ethiopia. Alber (2012) has argued that farmers in northern Benin intentionally take some of their children out of school to educate them in the household. Parents hope that the children educated at home will stay and care for them in old age, while schoolchildren are more likely to migrate to towns. Abebe describes the mismatch between children's aspirations, the national philosophy of rural development and local livelihood strategies in southern Ethiopia as follows:

"In this way, children and young people become redundant as their formal schooling becomes less useful, whereas traditional paths of livelihoods and socialisation simultaneously come under pressure. The result is young people's entrapment in 'disparate worlds' eroded tradition and an unfulfilled modern life - with compellingly bitter choices (in which they are uncertain about their decisions), causing them to be further excluded from participation in national development endeavours." (Abebe 2007, p. 23)

The challenges of ongoing transformations in rural Africa can hardly be addressed by schooling alone. Local economies in Ethiopia and elsewhere depend on the "chore curriculum", the opportunity for children to learn, work and participate in households. Instead of looking at work as a hindrance for schooling, further research, as well as government policies, should therefore concentrate on enabling people to combine various forms of education, work and schooling in order to ensure that all household members can make a living in the present and in the future.

\section{References}

Abebe, T. (2007): Trapped between Disparate Worlds? The Livelihoods, Socialisation and School Contexts of Rural Children in Ethiopia. In: Childhoods Today 1(1): 1-29.

Abebe, T./Ofosu-Kusi, Y. (2016): Beyond Pluralizing African Childhoods: Introduction. In: Childhood 23(3): 303-316. 
Abbink, J. (1997): The Shrinking Cultural and Political Space of East African Pastoral Societies. In: Nordic Journal of African Studies 6(1): 1-17.

Abbink, J./Askew, K./Dori, D. F. et al. (2014): Lands of the Future: Transforming Pastoral Lands and Livelihoods in Eastern Africa. Halle/Saale: Max-Planck Institute for Social Anthropology, Working Paper No.154.

Alber, E. (2012): Schooling or Working? How Family Decision Processes, Children's Agency and State Policy Influence the Life Paths of Children in Northern Benin. In: Spittler, G./Bourdillon, M. (eds.): African Children at Work. Working and Learning in Growing Up for Life. Wien, Zürich, Berlin, Münster: LIT, p. 169194.

Anderson-Levitt, K. M. (2005): The Schoolyard Gate: Schooling and Childhood in Global Perspective. In: Journal of Social History 38(4) : 987-1006.

Bierschenk, T. (2007): L'éducation de base en Afrique de l'Ouest francophone: Bien privé, bien public, bien global. In: Bierschenk, T./Blundo, G./Jaffré, Y./Alou, M. T. (eds.): Une anthropologie entre rigueur et engagement. Essais autour de l'oeuvre de Jean-Pierre Olivier de Sardan. Paris, Leiden: APAD- Karthala, p. 251-276.

Bourdillon, M./Levison, D./Myers, W./White, B. (2010): Work in Children's Development. In: Bourdillon, M./Levison, D./Myers, W./White, B. (eds.): Rights and Wrongs of Children's Work. New Brunswick, NJ: Rutgers University Press, p. 88-107.

Bourdillon, M./Spittler, G. (2012): Introduction. In: Spittler, G./Bourdillon, M. (eds.): African Children at Work. Working and Learning in Growing Up for Life. Wien, Zürich, Berlin, Münster: LIT, p. 1-22.

Donham, D. (2002 [1986]): Old Abyssinia and the New Ethiopian Empire: Themes in Social History. In: Donham, D. L./James, W. (eds.): The Southern Marches of Imperial Ethiopia. Essays in History and Social Anthropology. Oxford: James Currey, p.3-48.

Epple, S. (2012): Local Responses to Externally Induced Cultural Change: The Introduction of Formal Education in Bashada (Southern Ethiopia). In: Paideuma 58: 197-211.

Jeffrey, C. (2009): Fixing Futures: Educated Unemployment through a North Indian Lens. In: Comparative Studies in Society and History 51(1): 182-211.

Katz, C. (2004): Growing up Global: Economic Restructuring and Children's Everyday Lives. Minneapolis, London: University of Minnesota Press.

Krätli, S./Dyer, C. (2006): Education and Development for Nomads: The Issues and the Evidence. In: Dyer, C. (ed.): The Education of Nomadic Peoples. Current Issues, Future Prospects. New York: Berghahn Books, p. 8-34.

Klute, G. (1996): Kinderarbeit bei Nomaden. In: Beck, K./Spittler, G. (eds.): Arbeit in Afrika. Münster: LIT, p. 209-223.

Lancy, D. F. (2012): The Chore Curriculum. In: Spittler, G./Bourdillon, M. (eds.): African Children at Work. Working and Learning in Growing Up for Life. Wien, Zürich, Berlin, Münster: LIT, p. 23-56.

Lydall, J./Strecker, I. (1979): Baldambe Explains: The Hamar of Southern Ethiopia II. Hohenschäftlarn: Klaus Renner Verlag.

Lydall, J. (1993): Versöhnte Kontraste: Mit meinen Kindern bei den Hamar Äthiopiens. In: van de Loo, M.-J./Reinhart, M. (eds.): Kinder. Ethnologische Forschungen in fünf Kontinenten. München: Trickster, p. 18-44. 
Lydall, J. (2000): The Threat of the HIV/AIDS Epidemic in South Omo Zone, Southern Ethiopia. Northeast African Studies 7(1): 41-62.

Lydall, J. (2005): Hamär Dialect Cluster. In: Uhlig, S. (ed.): Encyclopaedia Aethiopica. D-Ha. Wiesbaden: Harrassowitz, p. 983-984.

Lydall, J. (2010): The Paternalistic Neighbor: A Tale of the Demise of Cherished Traditions. In: Gabbert, E. C./Thubauville, S. (eds.): To Live with Others. Essays on Cultural Neighborhood in Southern Ethiopia. Köln: Köppe, p. 314-334.

Martin, J. (2012): Children's Work, Child Fostering and the Spread of Formal Schooling in Northern Benin. In: Spittler, G./Bourdillon, M. (eds.): African Children at Work. Working and Learning in Growing Up for Life. Wien, Zürich, Berlin, Münster: LIT, p.195-226.

Maurus, S. (2016): Times of Continuity and Development: Visions of the Future among Agro-Pastoral Children and Young People in Southern Ethiopia. AnthropoChildren, 6. http://popups.ulg.ac.be/2034-8517/index.php?id=2494\&file=1 [Accessed: 06.02.2018].

Orkin, K. (2012): Are Work and Schooling Complementary or Competitive for Children in Rural Ethiopia? A Mixed-Methods Study. In: Boyden, J./Bourdillon, M. (eds.): Childhood Poverty. Multidisciplinary Approaches. Houndmills, New York: Palgrave Macmillan, p. 298-313.

Polak, B. (1998): Wie Bamana Kinder Feldarbeit lernen. In: Schmidt, H./Wirz, A. (eds.): Afrika und das Andere. Alterität und Innovation. Münster: Lit Verlag, p. 103-114.

Stambach, A. (2000): Lessons from Mount Kilimanjaro: Schooling, Community, and Gender in East Africa. New York, London: Routledge.

Stambach, A. (2017): Student Futures and the Politics of Possibility: An Introduction. In: Stambach, A./Hall, K. D. (Eds.): Anthropological Perspectives on Student Futures. Youth and the Politics of Possibility. Palgrave Macmillan, p.1-16.

Strecker, I. (2005): Hamär Ethnography. In: Uhlig, S. (Ed.): Encyclopaedia Aethiopica. D-Ha. Wiesbaden: Harrassowitz, p. 984-986. 


\title{
8 Wege der Transmission von Bildungskonzepten in einer globalisierten Welt. Das Beispiel der Transformation des National Achievement Surveys in Indien
}

\author{
Theresa Vollmer
}

\subsection{Einleitung 1}

Unter der gegenwärtigen Transnationalisierung von Bildung kommt es nach Münch (2012, S. 410) zu einer „Machtverschiebung im Feld der Bildung“. Bildung ist nicht länger alleinige Angelegenheit von Nationalstaaten, sondern internationale Organisationen wie beispielsweise die OECD und weitere private Akteure greifen vermittels von "Monitoring und Benchmarking“ (ebd.) massiv in lokale Bildungspolitiken und Bildungspraktiken ein. Nationale Bildungssysteme und Bildungspolitiken sehen sich einer globalen „Dauerbeobachtung" (ebd.) ausgesetzt und können sich bedeutender internationaler Vergleichsstudien wie beispielsweise PISA (OECD 2016) kaum entziehen. Obwohl angesichts globaler Transformationen nationale Bildungsforschung und Bildungspolitik herausgefordert sind, "new ways of recognizing, validating and assessing learning" (UNESCO 2015, S. 10) zu finden und dabei Diversität stärker zu berücksichtigen, scheint es zu einer Angleichung von lokalen Testkonzepten an das Testkonzept der PISA-Studie zu kommen. Lockheed (2013, S. 176) spricht von "spill-over effects on national assess-

1 Der vorliegende Beitrag ist Teil eines Dissertationsprojekts zur globalen Transmission der von der Organization for Economic Cooperation and Development (OECD) gesteuerten Bildungskonzepte, sowie deren Institutionalisierungs- wie Abstoßungsprozesse anhand des konkreten Beispiels Indien. Gegenstand der Untersuchung sind die aktuelle globale Vernetzung von Akteuren und Semantiken im Bildungssektor und die daraus resultierenden Transformationsprozesse auf lokaler Ebene. Das Dissertationsprojekt wird am Lehrstuhl Allgemeine Pädagogik an der Universität Bayreuth durchgeführt. Dieses wird durch die gemeinsame Initiative „Qualitätsoffensive Lehrerbildung“ von Bund und Ländern aus Mitteln des Bundesministeriums für Bildung und Forschung gefördert (01JA1601). Die Verantwortung für den Inhalt dieser Veröffentlichung obliegt der Autorin. 
ments", welche indirekt durch eine Teilnahme an der PISA-Studie und direkt durch externe Assistenz bewirkt werden. Insbesondere finde die Testmethodik der PISA-Studie große Beachtung bei der Umgestaltung nationaler Testkonzepte. Nach Bloem (2016) verschärft dies allerdings die Machtverschiebung unter Akteuren der nationalen wie internationalen Bildungspolitik und steuerung. Internationale Organisationen stärken dabei ihre Position im Feld der Leistungsmessung und lokale Newcomer-Akteure beeinflussen zunehmend lokale Bildungsentscheidungen.

Anhand des Beispiels der Transformation des National Achievement Surveys (NAS) in Indien möchte ich nachzeichnen, wie global kursierende Bildungskonzeptangebote - konkret die Item-Response-Theorie (IRT) ${ }^{2}$, welche Anwendung in der PISA-Studie der OECD findet - lokal aufgegriffen und prozessiert werden. Das Beispiel eignet sich gerade deshalb exponiert zur Diskussion der beschriebenen Prozesse, da eine Partizipation an der PISAStudie nach negativen Erfahrungen des PISA 2009 Plus Projekts (vgl. Walker 2011) von der indischen Regierung zwar abgelehnt wurde, diese gleichwohl darauf bezogene Transformationsprozesse im indischen Bildungssystem veranlasste. Forschung ist notwendig, um den Transformationsprozess des nationalen Testkonzepts zu untersuchen und um dadurch besser zu verstehen, wie PISA als wirkmächtiger Akteur (Münch 2012; Bloem 2016) lokale Bildungspolitik und -praxis beeinflusst. Wie gelangt die Item-Response-Theorie in den National Achievement Survey? Wer ist an der Umwandlung beteiligt? Wie verändert sich die Testdurchführung durch die internationale Zusammenarbeit?

Ziel des Artikels ist zu analysieren, wie das Wissen zur Item-ResponseTheorie bei der Transformation des NAS verhandelt und verbreitet wird und hierzu eine erste Beschreibung dieses Transformationsprozesses vorzulegen. Es wird der Aspekt des Austauschs von Wissen fokussiert. Das Konzept der „globally travelling ideas“ (Czarniawska/Sevón 2005) wird aufgegriffen und in Bezug gesetzt mit dem Konzept der „trading zones of knowledge“ (Galison 1997). Letzteres bietet den Vorteil, dass (möglichst) alle Akteure und deren Interaktionen in die Analyse miteinbezogen werden. Das Thema wird weder mit einem diskursorientierten Ansatz (vgl. Czarniawska/Sevón 2005) noch mit dem Neo-Institutionalismus (vgl. Krücken 2005), sondern netzwerktheoretisch (White 2008; White/Godart 2010) untersucht. Netzwerktheoretische Perspektiven ermöglichen es, die Struktur und Dynamik der internationalen Verflechtung der Bildungsakteure zu erforschen. Durch das Konzept

2 Mithilfe der Item-Response-Theorie werden Persönlichkeitseigenschaften und -fähigkeiten in zweigliedrigen oder in mehrgliedrig gestuften Test-Items erhoben und mathematisch analysiert. Dabei wird die Wahrscheinlichkeit einer speziellen Antwort auf ein Test-Item in die Analyse miteinbezogen (vgl. Geiser/Eid 2010). 
der Geschichten (stories) wird die Relationalität ${ }^{3}$ der an der Transformation beteiligten Akteure beschreibbar. Eine Beschäftigung mit dem netzwerktheoretischen Ansatz Whites' lohnt, da hiermit erziehungswissenschaftliche Fragen kulturtheoretisch betrachtet und kultursensitiv untersucht werden können (vgl. Clemens 2015).

Um herauszufinden, wie die Item-Response-Theorie in den NAS gelangt, werden Dokumente wie Jahresberichte, Konzeptpapiere, Veröffentlichungen und Konferenzpaper ausgewertet. Besonders hervorzuheben ist ein Konzeptpapier der Institution National Council of Educational Research and Training $\left(\right.$ NCERT) ${ }^{4}$ zur Item-Response-Theorie (vgl. DEME/NCERT o.D.). ${ }^{5}$ Das Augenmerk der Analyse ist in einem ersten Schritt auf die Beschreibung der formalen Organisation der Transformation gerichtet, um beteiligte Akteure zu identifizieren. In einem zweiten Schritt wird die Relationalität dieser Akteure genauer untersucht. Es wird das Ergebnis der Transformation vorgestellt und es folgt die Beschreibung und Analyse des Transformationsprozesses. Die Ergebnisse der Analyse werden mit dem o.g. theoretischen Ansatz in Bezug gesetzt und in den Kontext aktueller Forschungsliteratur gestellt. Das Forschungsvorhaben ist interdisziplinär und international ausgerichtet und wird in einer weit definierten vergleichenden Erziehungswissenschaft (vgl. Amaral/Amos 2015) verortet. Es handelt sich um ein noch nicht abgeschlossenes Forschungsvorhaben.

Das Beispiel der Transformation des National Achievement Surveys zeigt anschaulich, dass sich die Verknüpfungen, Positionen und Einflussmöglichkeiten der Akteure in der Zusammenarbeit stetig verändern. Es sind verschiedene Akteure beteiligt, die je eigene Interessen verfolgen (vgl. Fulge et al. 2016). Die Item-Response-Theorie aufzunehmen ist weder allein Motiv von Partnern der Entwicklungszusammenarbeit, noch allein dasjenige der indischen Regierung oder des NCERTs. Die Entscheidung Indiens zur Adoption der Item-Response-Theorie erfolgt vor dem Hintergrund der Beobachtung globaler Entwicklungen in der bildungswissenschaftlichen Diskussion und Praxis (vgl. DEME/NCERT o.D.). Es zeigt sich in der Analyse der vorliegenden Dokumente, dass die Ausrichtung des eigenständigen, vorhandenen

3 Der Begriff der Relationalität richtet das Interesse auf die Beziehungen (ties) zwischen Akteuren, auf das was zwischen den Akteuren geschieht (vgl. Clemens 2015).

4 Die Institution NCERT wurde im Jahr 1961 gegründet. Die zentrale Aufgabe des NCERTs ist die bildungswissenschaftliche Beratung der indischen Regierung. Weitere Aufgaben liegen in der Bildungsforschung, in der Lehrerbildung sowie in der Entwicklung von Lehrplan und Lehrmaterialien (vgl. Oza et al. 2015; NCERT-Webseite: http://ncert.nic.in/ [Zugriff: 19.09.2018]).

5 Das Konzeptpapier des NCERTs ist ohne Datum im Internet veröffentlicht (vgl. DEME/NCERT o. D.). Die Entstehung des Dokuments wird auf die Zeitspanne 2009 bis 2012 datiert. Dies begründet sich zum einen aus der im Dokument verwendeten Literatur, und zum anderen aus der Neuorganisation des NCERTs. 
Testkonzepts durch internationalen direkten und indirekten Einfluss verändert wurde. Es deutet sich eine Angleichung des transformierten Testkonzepts des NAS an das PISA-Modell an.

\subsection{Der National Achievement Survey (NAS)}

Der National Achievement Survey (NAS) der indischen Regierung ist ein Large-Scale-Assessment-Konzept mit nationaler Reichweite. Ziel und Anspruch des NAS ist, Informationen über Schülerleistungen der Jahrgangsstufen drei, fünf, acht und zehn für Bildungsplanungsprozesse bereitzustellen. Mit der Organisation und Durchführung des Testkonzepts ist der NCERT betraut. Von 2001 bis 2012 ist hierfür das Department of Educational Measurement and Evaluation (DEME) zuständig, nach 2012 ist es die Abteilung Educational Survey Division (ESD) (vgl. Oza et al. 2015). Um den Einfluss der Bildungsprogramme District Primary Education Programme (DPEP) und Sarva Shiksha Abhiyan (SSA) auf die Bildungsqualität im Primarbereich in Indien zu überprüfen, werden Vorläufertests des NAS durchgeführt (vgl. DEME/NCERT o.D.). In einem weiteren Schritt wird der Test auf den Sekundarbereich ausgeweitet, um auch die Wirkungsweise des Bildungsprogramms Rashtriya Madhyamik Shiksha Abhiyan (RMSA) zu evaluieren. Die Bezeichnung National Achievement Survey wird erstmalig im Jahr 2009 gebraucht (vgl. Oza et al. 2015). Die Item-Response-Theorie wird in der Erhebungswelle von 2009 bis 2013 eingeführt (vgl. NCERT 2015). Vor der Transformation wird die Durchführung des Tests von Oza/Betell (2013) als wenig wirksam eingeschätzt. Als Problem wird die von Hand ausgeführte Datenerhebung und Datenverarbeitung, welche einen hohen Zeitaufwand bedeutet und zudem fehleranfällig sei, genannt. Das Ziel der internationalen Zusammenarbeit liegt nach Oza/Bethell (2013) im Austausch von Wissen, im Aufbau von fachkundigem Personal, in der Verbesserung des Testkonzepts, sowie in einer nachhaltigen Einrichtung von nationalen Schülerleistungsvergleichstests. Nach Oza et al. (2015) ist das zentrale Ziel die Einführung internationaler Standards auf dem Gebiet des Large-Scale-Assessments. Ein weiteres Ziel ist es, die Organisation des NCERT effektiver zu gestalten. 


\subsection{Internationale Bildungsforschung und -steuerung als Auslöser für die Transformation des NAS}

Das internationale Interesse an der zügigen, weltweiten Durchsetzung von formaler allgemeiner Schulbildung, der sog. ,global Education for All drive” (Oza et al. 2015, S. 3), und die internationale Entwicklungszusammenarbeit beeinflussen die nationale Bildungspolitik in Indien. Aus der Perspektive des NCERTs (DEME/NCERT o.D.) werden unter der Prämisse qualitativ gute Bildung für alle Kinder und Jugendlichen zu generieren, zum einen die o.g. großangelegten Bildungsprogramme DPEP, SSA und RMSA mithilfe von externen Akteuren durchgeführt und zum anderen der National Achievement Survey eingeführt, um Informationen für nationale und internationale Akteure der Bildungspolitik und -steuerung bereitzustellen. Es wird eine Diskrepanz zwischen den Testkonzepten, die in Indien weitläufig angewendet werden, und den Testkonzepten, die international Beachtung finden, festgestellt. Nach Oza et al. (2015) erfolgt eine intensive Auseinandersetzung mit der internationalen Bildungsforschung zum Thema Large-Scale-Assessment. Internationale Entwicklungen in der Bildungsforschung werden in Indien beobachtet und dahingehend geprüft, „how far their practices are transferable to NAS“ (ebd., S. 8). Internationale Testkonzeptionen wie beispielsweise PISA und TIMMS werden im Hinblick auf Qualitätsstandards untersucht. Aus dem Konzeptpapier (DEME/NCERT o.D.) geht hervor, dass die Entscheidung für eine Aufnahme der Item-Response-Theorie vom NCERT getroffen wird und aus dem Motiv heraus erfolgt, Anschluss an den internationalen Standard zu erhalten. Beweggründe sind hierfür die Möglichkeit der Zeitersparnis beim Testen sowie eine Verringerung der Anzahl der TestItems. Dagegen wird nach Oza et al. (2015) die Entscheidung der Adoption der Item-Response-Theorie von den beteiligten indischen und britischen Akteuren getragen.

\subsection{Die Transformation des National Achievement Surveys}

\subsubsection{Die formale Organisation der Transformation}

Die Weiterentwicklung des National Achievement Surveys wird als ein britisch-indisches Hilfsprojekt von 2008 bis 2016 durch Finanzierung und Beratung gefördert. Es bildet sich eine Unterstützungsbeziehung zwischen dem 
Department for International Development (DFID) ${ }^{6}$ als einer Institution der britischen Regierung, und dem NCERT als Organisation mit beratender Funktion der indischen Regierung. Bei der Weiterentwicklung des NAS unterstützt das DFID den NCERT durch die Einrichtung eines Technical Cooperation Funds (TCF) und durch die Beratungsfirma Cambridge Education, die ebenfalls ein Arbeitsteam zur Verfügung stellt: die Technical Support Agency (TSA). Deren Aufgabe ist, "to assist NCERT to strengthen NAS and to introduce international best practices, techniques and standards in conducting large scale national assessment survey" (Oza et al. 2015, S. 6). Dies bedeutet konkret die Einführung der Item-Response-Theorie.

In der ersten Phase der internationalen Zusammenarbeit von 2008 bis 2012 besteht eine Kooperation zwischen den o.g. Akteuren. Die Intervention steht in Zusammenhang mit dem SSA-Bildungsprogramm. Nach Oza et al. (2015) sind des Weiteren die Organisationen Anglia Assessment (UK) und Educational Testing Service (ETS) (USA) beteiligt. Aus dieser Phase geht das Konzeptpapier des NCERTs zur Item-Response-Theorie (DEME/NCERT o. D.) und eine gemeinsame Publikation von Oza und Bethell (2013) hervor. Jayshree Oza ist Consultant für Bildungsmanagement bei Cambridge Education. George Bethell ist Direktor und Senior Consultant bei Anglia Assessment.

In der zweiten Phase der internationalen Zusammenarbeit von 2013 bis 2016 wird der NCERT durch die Technical Cooperation Agency (TCA) der Beratungsfirma Cambridge Education begleitet und wiederum durch den DFID gefördert. Die Intervention ist an das RMSA-Bildungsprogramm geknüpft. Die Leitung des RMSA-TCA-Teams obliegt Jayshree Oza. In der zweiten Phase wird die Kooperation zwischen o.g. Akteuren durch indische Akteure wie zum Beispiel der National University of Educational Planning and Administration (NUEPA) erweitert (vgl. Oza 2015). Cambridge Education wird u.a. durch die Organisation Australian Council for Educational Research (ACER) (Australien) beraten (vgl. Oza et al. 2015). Es entsteht eine Publikation aus der Perspektive Jayshree Ozas über die Zusammenarbeit mit dem NCERT (Oza 2015) sowie eine gemeinsame Publikation des NCERTs und des RMSA-TCA-Teams (Oza et al. 2015).

6 Das DFID ist eine Institution der Regierung Großbritanniens und wurde 1997 gegründet. Mit dem Fokus der Reduktion von Armut fördert das DFID zusammen mit Partnerorganisatoren weltweit

Bildungsprojekte

(siehe

DFID-Webseite: https://www.gov.uk/government/organisations/department-for-internationaldevelopment/about [Zugriff: 19.09.2018]). 


\subsubsection{Die Transformation des National Achievement Surveys durch die Adoption der Item-Response-Theorie}

Es zeigt sich in der Analyse der vorliegenden Dokumente, dass die Ausrichtung des eigenständigen indischen Testkonzepts durch internationalen direkten und indirekten Einfluss verändert wurde. Direkt durch die Zusammenarbeit Indiens mit Partnern der Entwicklungszusammenarbeit und indirekt durch den eingangs beschriebenen Einfluss der PISA-Studie der OECD (vgl. Lockheed 2013). Es deutet sich eine Angleichung des transformierten Testkonzepts des National Achievement Surveys an das PISA-Modell im Hinblick auf die Testtechnik, die Testbereiche, sowie die visuelle Aufbereitung der Berichte an (vgl. NCERT 2014).

An technischer Ausstattung werden im NCERT Neu-Delhi sowie in den regionalen Zentren des NCERT I) Computer Hardware, wie z.B. Notebooks und Scanner, II) Computer Software, wie z.B. Datenlese- und Datenverarbeitungsprogramme: Scanprogramme, Microsoft Office, SPSS und weitere neu eingeführt. Des Weiteren wird III) ein NCERT-internes Netzwerk eingerichtet. Das Personal wird in der Anwendung von Datenverarbeitungs- und Datenanalyseprogrammen fortgebildet. Änderungen erfolgen somit sowohl auf technologischer Ebene, als auch auf der Ebene der Mitarbeiterfortbildung (vgl. Oza/Bethell 2013). Das Ziel einer nachhaltigeren Gestaltung der organisationalen Prozesse in der Institution NCERT wird insofern erreicht, als ,the [organization] had undergone a cultural shift in that the use of computers to produce documents, and store and transfer information is now the norm." (ebd., S. 43). Die schnellere Organisation des Testverlaufs wird als Erfolg angesehen und die Verwendung von Scannern und Dateneinleseprogrammen wird als zukunftsweisend für den indischen Kontext eingestuft. Die Erhöhung der Testqualität des National Achievement Surveys ist für Oza et al. (2015) Orientierung für die Zukunft und zugleich zentrale Herausforderung.

\subsubsection{Eine erste Beschreibung des Transformationsprozesses}

Die Transformation des NAS wird von der Teamleiterin als ,progressive development" (Oza 2015, S. i) bezeichnet. Es sei möglich weitreichenden Wandel durch externe technische Assistenz zu erreichen. Die Ausgestaltung der internationalen Hilfsbeziehung habe sich über die zwei Förderphasen gewandelt. Die Zusammenarbeit habe zu Beginn auf einer "technical cooperation relationship which is based on high reliance on external technical support" (ebd., S. 3) beruht. Im Verlauf der Zusammenarbeit habe sich eine Beziehung entwickelt, ,where technical capacity has been more established in the beneficiary" (ebd.). Die geleistete externe Hilfe habe die Führungsund Entscheidungskompetenz der indischen Regierung stets respektiert. 
Jayshree Oza war aktiv an der Transformation des NAS beteiligt und wirkte zugleich an der Evaluation des Transformationsprozesses durch wissenschaftliche Veröffentlichungen mit. Kritisch ist m.E. zu fragen, inwiefern auf diese Weise Neutralität gewährleistest werden kann. So zeichnen Menashy/Shields (2017) mit ihrer Forschungsarbeit ein anderes Bild. Die seit 2005 in der Entwicklungszusammenarbeit forcierten "new partnerships" (ebd., S. 495), welche partnerschaftliche Teilhabe von Geber und Empfänger anstelle von einseitiger Geber-Dominanz fördern, tragen in der Realität zu einer Verfestigung der ungleichmäßigen Machtverhältnisse bei. Aus netzwerkanalytischer Perspektive zeigen die Autoren, dass internationale Akteure als "donors" (ebd.) zentral positioniert sind, wohingegen lokale Akteure als ,recipient governments" (ebd.) u.w.m. am äußeren Rand des Netzwerks verortet sind. Die Ungleichheit ergibt sich aus den unterschiedlichen Positionen: GeberPositionen "enjoy high levels of connectivity to many organisations" (ebd.), they "shape the flow of information and ideas between organisations, influence the distribution of resources among members, and determine normative preferences of the partnerships" (ebd.). Empfängerpositionen verfügen über weniger Verknüpfungen zu anderen (internationalen) Akteuren und haben somit weniger Einflussmöglichkeiten. Die Autoren beachten in ihrer Arbeit jedoch m.E. nicht ausreichend, dass auch Akteure in Empfängerkontexten Einfluss auf internationale Netzwerke nehmen (siehe Bloem 2016; Fulge et al. 2016) und verbleiben mit ihrer Analyse im Zentrum-Peripherie-Modell der Diffusion von Ideen (vgl. Rogers 2003; Czarniawska/Sevón 2005). Krücken (2005) kritisiert diese Diffusionshypothese, einer linearen Verbreitung der World Polity-Prinzipien von Sender zu Empfänger, als zu einfach. World Polity gilt ,als unveränderlicher virtueller ,Sender“" (ebd., S. 315) und „Rückkopplungseffekte“ (ebd.) zwischen Sender und Empfänger werden nicht genug berücksichtigt. Der Autor weist auf die Nichtbeachtung von Kultur und Struktur von „,Empfänger'-Kontexte[n]“ (ebd.) als ein Forschungsdesiderat im neo-institutionalistischen Ansatz hin, ein Aspekt, der für die theoretische Grundlegung meines Forschungsvorhabens jedoch konstitutives Element ist. Krücken stellt die These auf, dass sich unter Bedingungen von Globalisierung ${ }^{7}$ vielmehr vielfältige und zum Teil gegensätzliche „Kultur- und Strukturmuster" (ebd.) begegnen.

Auch Raina (2009, 2011, 2016) betrachtet die Diffusionshypothese als problematisch. Er weist darauf hin, dass im internationalen Austausch von Wissen nicht nur Empfängerkontexte eine Transformation erfahren, sondern auch Geberkontexte. Es handelt sich mindestens um „two way flows of knowledge and practices" (Raina 2011, S. 175). Der Prozess der Transmission von Wissen verlaufe meist nicht linear, sondern eher multidirektional. 
Rainas Ansatz der ,[m]ulti directional arrows of influence constituting a network" (Raina 2009, S. 621) richtet den Blick auf die internationale Verknüpfung von Akteuren. Es wird hierbei auf postkoloniale Standpunkte verwiesen und darauf aufmerksam gemacht, dass, indigene" oder nicht-westliche Perspektiven stärker berücksichtigt werden müssen, wenn Prozesse der Sinngenerierung global untersucht werden sollen (vgl. Raina 2009, 2016; Clemens 2009; siehe auch Clemens/Biswas 2019 in diesem Band). Auf der Basis bisheriger Recherche verwende ich daher anstelle des Begriffs der Diffusion den Begriff der Transmission. Dieser Begriff bringt den Vorteil mit sich, dass er dynamischer ist und voraussetzt, dass diverse Akteure etwas zum Verbreitungsprozess beitragen. Hier ist das Konzept der ,trading zones“ (Galison 1997) anschlussfähig, da in diesem nicht vereinfacht von Sender und Empfänger ausgegangen wird, sondern (möglichst) alle beteiligten Akteure wahrgenommen und in die Untersuchung miteinbezogen werden. Galison (1997) fasst „trading zones“ als Orte, an denen Wissen verhandelt werden kann, an dem Austausch und Zusammenarbeit möglich ist, ,,collaboration consisted of establishing a place where ideas, data, and equipment could be passed back and forth between groups - constituting a trading zone" (Galison 1997, S. 817). Der Fokus ist auf Interaktion und Sinngenerierung als dynamischen Prozess gerichtet. Um nun herausfinden zu können, wie die Item-ResponseTheorie in den NAS gelangt ist, bietet sich das Konzept der Geschichten (stories) nach White (2008) an. Danach versuchen Akteure über Geschichten Handlungen in sozialen Interaktionen zu steuern. Gleichzeitig eröffnen Geschichten Akteuren Zugang zu neuen Netzwerken: „For participants, stories are the key" (White 2008, S. 27).

Geschichten dienen nach Clemens (2015, S. 238f) zur Interpretation von Beziehungen, zur Formulierung einer Perspektive, zur Ordnung und Verwaltung von „Erwartungen oder Ansprüche[n]“ sowie zur Generierung von Bedeutung. Geschichten bieten Informationen über die Qualität der Beziehungen, über die Verortung der Akteure in der Beziehung und über mögliche Handlungsformen der beteiligten Akteure. „Auch Organisationen oder andere Netzwerke erzählen Geschichten“ (ebd., S. 242), wie die Autorin hervorhebt, „und sichern so ihre Legitimation und ihre Eingebundenheit in ein größeres Netzwerk" (ebd.). Geschichten spielen auch eine Rolle bei der Bearbeitung des alltäglichen und besonderen Geschehens: „Geschichten prägen und definieren die Ereignisse im Nachhinein in eine [Standardgeschichte] um und verleihen ihnen damit eine allgemeine Form" (ebd., S. 241).

Die Darstellung der Transformation des National Achievement Surveys in den Berichten des NCERTs und der Partner der Entwicklungszusammenarbeit liest sich als eine solche Standardgeschichte. Large-Scale-Assessment und insbesondere die Item-Response-Theorie sind zunächst „,new territory“ (Oza 2015, S. 3) für den NCERT. Im Konzeptpapier des NCERTs heißt es: 
"IRT is a relatively new area of endeavor that has been undertaken by DEME." (DEME/NCERT o.D., S. 13)

Und weiter:

"Newer knowledge and insights are expected to emerge that are likely to improve our ability and capability to upgrade ourselves in the field of measurement and evaluation" (ebd., S. 13).

Aus diesem Statement geht hervor, dass sich der NCERT zum einen einen Zuwachs an Wissen erwartet, zum anderen aber auch eine Veränderung der Position Indiens auf globaler Ebene erhofft. Cambridge Education und Anglia Assessment verfügen über das durch die indische Regierung angefragte Wissen zur Item-Response-Theorie (vgl. Oza 2015). Im Rahmen der internationalen Zusammenarbeit emergiert dieses Wissen in einer trading zone. Durch die externe Assistenz kann der NCERT Verknüpfungen zu internationalen Organisationen wie beispielsweise ACER erschließen und hat dadurch Zugang zu neuem Wissen. Es werden wichtige Akteure und Konferenzen besucht, Journale abonniert, und neue Kontakte geknüpft (vgl. Oza et al. 2015). Die Transformation des NAS führt somit zu einer Erweiterung des Netzwerks des NCERTs. Aus der Sicht Oza/Bethells (2013) habe die externe Assistenz dazu beigetragen, dass lokalen Experten in Indien der Anschluss an die internationale Large-Scale-Assessment-Fachdiskussion gelingen kann:

"The support provided through the SSA-TCF has ensured that NCERT faculty members can now participate in debates related to assessment and psychometrics." (ebd., S. 9)

Oza/Bethell (2013) berichten nicht nur über die Transformation des National Achievement Surveys, sondern diskutieren auch Indiens Teilnahme am PISA 2009 Plus Projekt. Darüber hinaus tragen die Autoren weitere Akteure im Bereich der Leistungsmessung in Indien zusammen. Beispielhaft werden die privaten Akteure ASER (ASER centre 2017) und Educational Initiatives (Educational Initiatives/Wipro 2011) genannt. Durch die Transformation kommt es demnach nicht nur zu einem Wissenszuwachs auf Seiten den NCERTS, sondern auch auf Seite von Cambridge Education und Anglia Assessment. Die britisch-indische Zusammenarbeit verändert nicht nur das Netzwerk des NCERTs, sondern auch das der Organisation Cambridge Education. Es kommt zu einer Verdichtung des internationalen Netzwerkes der Organisation, indem bestehende Verknüpfungen zu anderen internationalen und nationalen Akteuren intensiviert werden und neue Kontakte geknüpft werden. Beispielsweise ist die Beraterin Jayshree Oza auch Teil des Teams der Central Square Foundation (CSF). Der indische Newcomer-Akteur CSF (gegründet 2012), dessen Interesse die Entwicklung und Durchsetzung von Leistungsmessung im indischen Kontext ist, nimmt Einfluss auf die indische Bildungspolitik, indem er zum Beispiel die Regierung des indischen Bundesstaats Himachal Pradesh in der Durchführung von Large-Scale-Assessments 
berät. ${ }^{8}$ Durch Newcomer-Akteure wie die CSF, aber auch durch zentrale Akteure wie Jayshree Oza, wird sichtbar, wie Stiftungen und Beratungsfirmen nationale Bildungspolitik beeinflussen und mitgestalten. Dies wirft m.E. einmal mehr die Frage nach dem Kräfteverhältnis zwischen staatlichen und privaten Akteuren im Bildungssektor auf.

\subsection{Ausblick}

Aufgabe in weiteren Forschungsprozessen ist es, beteiligte Akteure am Transformationsprozess des National Achievement Surveys zu befragen, um die Standardgeschichte der partnerschaftlichen Transformation mit möglichen alternativen Geschichten zu kontrastieren. So könnten Aspekte wie Macht und Einflussnahme im Entscheidungsprozess zur Adoption der ItemResponse-Theorie besser analysiert werden. Hierbei ist auch interessant die Rolle der OECD in den Blick zu nehmen. Des Weiteren ist ein Vergleich des transformierten Testkonzepts des NAS mit dem Testkonzept der PISA-Studie notwendig, um die Testkonzepte auf Ähnlichkeiten und Unterschiede zu prüfen. Um neue Testkonzepte zu entwickeln, welche Diversität stärker berücksichtigen (vgl. UNESCO 2015), ist es zudem lohnend, alternative Testkonzepte wie beispielsweise ASER (vgl. ASER 2017) im europäischen Forschungsraum mehr zu diskutieren. Aus der Betrachtung des Beispiels Indiens können Rückschlüsse für den eigenen Kontext gezogen werden. Es lässt sich etwas darüber lernen, wie mit PISA und damit verbundenen Transformationen in anderen Kontexten umgegangen wird.

\section{Literatur}

Amaral, M. P./Amos, S. K. (2015): Internationale und Vergleichende Erziehungswissenschaft. Geschichte, Theorie, Methode und Forschungsfelder. Reihe: New frontiers in comparative education, 2. Münster: Waxmann.

ASER centre (2017): Annual Status of Education Report (rural) 2016, New Delhi: ASER

centre. http:/img.asercentre.org/docs/Publications/ASER\%20Reports/ASER\%202016/as er_2016.pdf [Zugriff: 19.09.2018].

8 Webseite der Central Square Foundation: http:/centralsquarefoundation.org/ [Zugriff: 19.09.2018]. 
Bloem, S. (2016): Die PISA-Strategie der OECD. Zur Bildungspolitik eines globalen Akteurs, Weinheim und Basel: Beltz Juventa.

Clemens, I. (2009): Die Herausforderung Indigener Theorien. Die Frage nach der Relevanz kulturtheoretischer Perspektiven in der Erziehungswissenschaft am Beispiel der Emergenz Indigener Theorien. In: Zeitschrift für Pädagogik 55(1): 113-129.

Clemens, I. (2015): Erziehungswissenschaft als Kulturwissenschaft. Die Potentiale der Netzwerktheorie für eine kulturwissenschaftliche und kulturtheoretische Ausrichtung der Erziehungswissenschaft, Weinheim und Basel: Beltz Juventa.

Clemens, I./Wulf, C. (2011): Globalisierung. In: Holzbrecher, A. (Hrsg.): Interkulturelle Schule. Eine Entwicklungsaufgabe. Reihe: Politik und Bildung, 63. Schwalbach/ Ts: Wochenschau Verlag, S. 13-27.

Clemens, I./Biswas, T. (2019): Rethinking education in times of globalization - but where to start the rethinking? In: Clemens, I./Hornberg, S./Rieckmann, M. (Hrsg.): Bildung und Erziehung im Kontext globaler Transformationen. Opladen, Berlin, Toronto: Verlag Barbara Budrich, S. 235-248.

Czarniawska, B./Sevón, G. (Hrsg.) (2005): Global ideas. How ideas, objects and practices travel in the global economy. Advances in organization studies, 13. Malmö: Liber.

DEME/NCERT (o.D. [2009-2012]): Introduction of Item Response Theory in National Achievement Surveys under Sarva Shiksha Abhiyan. Concept note: Item Response Theory, New Delhi: NCERT. http://rmsaindia.gov.in/administrator/components/com pdf/pdf/d5bed249366e03 44a5f61625e3eeeafe-IRT-in-NAS.pdf [Zugriff: 19.09.2018].

Educational Initiatives/Wipro (2011): Quality Education Study (QES), Educational Initiatives Pvt. Ltd. http:/www.ei-india.com/quality-education-study-qes/ [Zugriff: 19.09.2018].

Fulge, T./Bieber, T./Martens, K. (2016): Rational Intentions and Unintended Consequences: On the Interplay Between International and National Actors in Education Policy. In: Mundy, K./Green, A./Lingard, B./Verger, A. (Hrsg.): Global Policy and Policy-Making in Education, Handbook of Global Policy Series, Hoboken: Wiley-Blackwell, S. 453-469.

Galison, P. L. (1997): Image and Logic. A Material Culture of Microphysics. Chicago: Univ. of Chicago Press.

Geiser, C./Eid, M. (2010): Item-Response-Theorie. In: Wolf, C./Best, H. (Hrsg.): Handbuch der sozialwissenschaftlichen Datenanalyse, Wiesbaden: VS Verlag für Sozialwissenschaften, S. 311-332.

Krücken, G. (2005): Der »world-polity«-Ansatz in der Globalisierungsdiskussion. In: Meyer, J. W./Krücken, G./Kuchler, B. (Hrsg.): Weltkultur. Wie die westlichen Prinzipien die Welt durchdringen. Reihe: Edition zweite Moderne. Frankfurt am Main: Suhrkamp, S. 300-318.

Lockheed, M. (2013): Causes and Consequences of International Assessments in Developing Countries. In: Meyer, H.-D./Benavot, A. (Hrsg.): PISA, Power, and Policy: The Emergence of Global Educational Governance, Oxford: Symposium Books, S. 163-183.

Menashy, F./Shields, R. (2017): Unequal partners? Networks, centrality, and aid to international education. In: Comparative Education 53(4): 495-517. 
Münch, R. (2012): Das PISA-Regime. Zur Transnationalisierung des Bildungsfeldes. In: Bernhard, S./Schmidt-Wellenburg, C. (Hrsg.): Feldanalyse als Forschungsprogramm 1. Der programmatische Kern, Wiesbaden: VS Verlag für Sozialwissenschaften, S. 405-425.

NCERT (2014): National Achievement Survey Class V, Cycle 3, National Subjectwise Report. Learning Gaps in Language, Mathematics and Environmental Studies, NCERT: New Delhi. http://www.ncert.nic.in/departments/nie/esd/pdf/NationalReport_subjectwise.pdf [Zugriff: 19.09.2018].

NCERT (2015): NCERT Annual Report 2013-14, NCERT: New Delhi. http:/www.ncert.nic.in/rightside/links/annual_report_13-14.html [Zugriff:19.09.2018].

OECD (2016): PISA 2015. Ergebnisse im Fokus, Paris: OECD. https://www.oecd.org/berlin/themen/pisastudie/PISA_2015_Zusammenfassung.pdf [Zugriff: 19.09.2018].

Oza, J./Bethell, G. (2013): Assessing Learning Outcomes: Policies, Progress and Challenges. Sarva Shiksha Abhiyan, DFID Funded Research Study, New Delhi: DFID.

http://rmsaindia.gov.in/administrator/components/com_pdf/pdf/cf76ea85f9799e7 b5654bf8b06a0282d-SSA-Learning-Assessment-Research-Study-Report--1306.pdf [Zugriff: 19.09.2018].

Oza, J./Yagnamurthy, S./Srivastava, S./Pennells, J. (2015): Evidence for learning: Supporting the development of the Government of India's National Achievement Survey. Conference Paper. UKFIET Conference. https://www.cambed.com/intdev/article/236/ukfiet-2015-supporting-the-development [Zugriff: 19.09.2018].

Oza, J. (2015): Working with NCERT on the Government of India's National Achievement Survey, Cambridge: Cambridge Education. https://www.cambed.com/intdev/article/246/cies-2015-indias-national-achievement-survey $\quad[\mathrm{Zu}-$ griff: 19.09.2018].

Raina, D. (2009): Knowledge. In: Iriye, A./Saunier, P.-Y. (Hrsg.): The Palgrave Dictionary of Transnational History. Hampshire: Palgrave Macmillan, S. 620-626.

Raina, D. (2011): Travelling Both ways: The Adoption of Disciplines, Scientific Textbooks and Institutions. In: Günergun, F./Raina, D. (Hrsg.): Science Between Europe and Asia. Boston Studies in the Philosophy of Science 275, Dordrecht: Springer Science and Business Media, S. 165-176.

Raina, D. (2016): After Exceptionalism and Heritage: Thinking through the Multiple Histories of Knowledge. In: Brentjes, S./Edis, T./Richter-Bernburg, L. (Hrsg.): 1001 distortions: how (not) to narrate history of science, medicine, and technology in non-western cultures. Reihe: Orientalistik, 25, Würzburg: Campus, S. 2538 .

Rogers, E. M. (2003): Diffusion of Innovations. Reie: Free Press Trade Paperback Ed. New York: Free Press, 5. Aufl.

UNESCO (2015): Rethinking education. Towards a global common good? Paris: UNESCO. http://unesdoc.unesco.org/images/0023/002325/232555e.pdf [Zugriff: 19.09.2018].

Walker, M. (2011): PISA 2009 Plus Results: Performance of 15-year-olds in reading, mathematics and science for 10 additional participants. Melbourne: Acer Press. 
https://research.acer.edu.au/cgi/viewcontent.cgi?article=1000\&context=pisa [Zugriff: 19.09.2018].

White, H. C. (2008): Identity and Control. How Social Formations Emerge, Princeton and Oxford: Princeton University Press.

White, H. C./Godart, F. C. (2010): Switchings under uncertainty: The coming and becoming of meanings. In: Poetics 38: 567-586. 


\title{
9 Europa zum Thema machen?! - Zur Konzeption von Unterrichtsmodulen für die Sekundarstufe
}

\author{
Marie Zipp-Timmer, Nadine Sonnenburg, Sabine Hornberg, \\ Saphira Shure
}

\section{$9.1 \quad$ Einleitung}

Vor dem Hintergrund der globalisierten Verhältnisse gibt es eine Reihe bedeutsamer Themen, die nicht alleine im Rahmen nationaler oder lokaler Auseinandersetzungen bearbeitet werden können, sondern die weltweite Zusammenarbeit erfordern. Die internationalen Verflechtungen und Abhängigkeiten werden aktuell insbesondere über Topoi wie ökologische Krisen, zunehmende Armutsverhältnisse und vielfältige Migrations- und Fluchtbewegungen betrachtet (Frech et al. 2014; Lawn/Grek 2012). In diesem Kontext hat sich die Bedeutung Europas, der europäischen Einigung und des supranationalen Staatenbundes Europäische Union (EU) im Hinblick auf politische, wirtschaftliche und zivilgesellschaftliche Zusammenhänge sichtlich erhöht (Hornberg/Sonnenburg 2017). So wirkt etwa die Politik der Institutionen der EU unmittelbar in die Lebenswelten aller Menschen hinein. Vor diesem Hintergrund gewinnt die Auseinandersetzung mit Europa und der EU an Relevanz (Hornberg 2010; Tömmel 2008; Schöne/Immerfall 2014); dem gegenüber steht ein Wissens- und Interessendefizit vieler Menschen hinsichtlich der EU und der europäischen Politik (Tham 2006; Schöne/Immerfall 2014). In diesem Spannungsfeld kommt unter anderem der Schule die Aufgabe zu, bei Schüler*innen ein Bewusstsein für Europa bzw. die EU zu fördern (Oberle 2015). Die Bildungsinstitution Schule kann dieser Aufgabe bspw. durch die Berücksichtigung von europabezogenen Themen im Unterricht nachkommen (Schöne/Immerfall 2014) und diese können u.a. im Rahmen von Fortbildungen für Lehrer*innen angebahnt werden.

Das Projekt „Europa in der Schule - Lehrerfortbildungen in NordrheinWestfalen" (ELIN) knüpft an die Idee von Professionalisierungsprozessen von Lehrer*innen im Hinblick auf europabezogene Themen an. Entsprechend wurden unter der Beteiligung von Wissenschaftler*innen, Lehrer*innen und Vertreter*innen des Ministeriums für Schule und Weiterbildung Nordrhein- 
Westfalen (MSW) vier europabezogene, kompetenzorientierte Unterrichtsmodule konzipiert und im Rahmen von Lehrer*innenfortbildungen vorgestellt und bearbeitet. Mit diesen Unterrichtsmodulen und den damit verbundenen Fortbildungsangeboten soll die Berücksichtigung von europabezogenen Themen in Schule und Unterricht gestärkt sowie ein Beitrag zur Diskussion hinsichtlich aktueller Anforderungen an Schule und Unterricht geleistet werden. Im vorliegenden Beitrag wird zunächst auf den Forschungsstand zum Themenfeld „Europa in der Schule“ eingegangen, um die Bedeutung und Zielrichtung des Projekts zu verdeutlichen. Anschließend wird das Design des Projekts ELIN erläutert, und es werden erste Ergebnisse des Projekts vorgestellt.

\subsection{Hintergrund und Forschungsstand}

In den vergangenen Jahrzehnten gab es zahlreiche Bemühungen das Thema Europa im Unterricht stärker zu verankern. Bereits Ende der 1980er Jahre waren die Mitgliedsstaaten der Europäischen Gemeinschaft (EG) bzw. der EU aufgefordert worden, ,die europäische Dimension in die Lehrpläne, in den Unterricht, in pädagogische Unterrichtsmaterialien, [und] die Lehrerausbildung und Schülerbegegnung zu integrieren“ (Hornberg 2010, S. 93). Im Jahr 1978 formulierte die Kultusministerkonferenz (KMK) zum ersten Mal Empfehlungen zu „Europa im Unterricht“, die zuletzt 2008 überarbeitet und mit dem Titel „Europabildung in der Schule“ von der KMK verabschiedet wurden. Dort wird gefordert, die Schule solle „Kompetenzen vermitteln, die zu einem gelingenden Leben in Europa befähigen“ (KMK 2008, S. 5) sowie ferner:

„[Die Schule] soll dazu beitragen, dass in der heranwachsenden Generation ein Bewusstsein europäischer Zusammengehörigkeit entsteht und Verständnis dafür entwickelt wird, dass in vielen Bereichen unseres Lebens europäische Bezüge wirksam sind und europäische Entscheidungen verlangt werden. Die Schule hat zudem die Aufgabe, Respekt vor und Interesse an der Vielfalt der Sprachen und Kulturen zu wecken und auszubauen." (ebd., S. 5)

Die Berücksichtigung von „Europa in der Schule“ wird im wissenschaftlichen Diskurs vor allem aus drei Perspektiven beleuchtet, die sich in erster Linie hinsichtlich der Annäherung an den Gegenstand unterscheiden; Janssen (1986) differenziert zwischen: Bildung in, über und für Europa. Während Forschungen im Kontext der interkulturellen Pädagogik vor allem Fragen nach der Berücksichtigung der Heterogenität ,,in pädagogischen Theorien, in rechtlichen und schulstrukturellen Rahmenvorgaben und in der Schulpraxis“" (Hornberg 2010, S. 88) in den Blick nehmen und damit der Frage nach Bil- 
dung in Europa folgen, nehmen politikdidaktische Forschungen vor allem die Vermittlung von Kenntnissen über Europa und für Europa in den Blick.

Als ein Beispiel für die „Bildung in, über und für Europa“ können in der Bundesrepublik Deutschland insbesondere die Europaschulen herangezogen werden. Europaschulen sind staatliche Schulen, die im Pflichtschulbereich angesiedelt, an die für sie geltenden Lehrplanvorgaben und Schulberechtigungen gebunden sind und die als zusätzlichen Schwerpunkt ein europaorientiertes Schulprofil verankert haben (Hornberg 2010). Empirische Befunde zu Europaschulen in Nordrhein-Westfalen (NRW) zeigen, dass diese Schulen ,vielseitige Betätigungsfelder zur Förderung europabezogener Kompetenzen bei ihren Schülerinnen und Schülern“ (Hornberg/Sonnenburg 2017, S. 16) entwickelt haben, wie bspw. spezifische Projekte zu Europa (ebd.).

Wird der Forschungsstand hinsichtlich einer „Bildung über Europa“ betrachtet, so zeigen insbesondere Forschungen im Feld der Politikdidaktik ein höchst differentes Bild: Die Empfehlungen der KMK (2008) zu Europa im Unterricht sind für die verschiedenen Bundesländer in Deutschland nicht bindend, entsprechend finden sich in den Kernlehrplänen und Bildungsplänen der Bundesrepublik unterschiedliche Vorschläge zur Umsetzung (Rappenglück 2014). Zudem wird kritisiert, dass der Unterricht von einer Fokussierung auf eine reine europäische Institutionenkunde gekennzeichnet sei, die der Komplexität des Themas nicht gerecht werde (Frech et al. 2014) und es zum Teil in Schulbüchern unpräzise Formulierungen gäbe sowie veraltete, teils inkorrekte Fakten zu Europa/der EU (Natterer 2001), wie auch Oberle (2012) zeigt, die eine oftmals vage, unspezifische und undifferenzierte Verwendung von Begriffen moniert (Oberle 2012).

In diesem Zusammenhang zeigen Studien, dass hinsichtlich der Umsetzung des Themas Europa im Unterricht unterschiedliche Herausforderungen identifiziert werden können. So fassen Schöne und Immerfall (2015) zusammen, dass der stetige Wandel und die rasche Entwicklung der EU zum einen die Aktualität der Materialien erschweren und zum anderen die Notwendigkeit einer regelmäßigen Fortbildung der Lehrer*innen betont (Schöne/ Immerfall 2015). Auch Oberle und Forstmann (2015) kommen in ihrer Begleitforschung zu Lehrerfortbildungen mit insgesamt 169 befragten Teilnehmer*innen zur politischen EU-Bildung zu dem Ergebnis, dass Fortbildungsbedarf zu europäischen Themen und ihrer Vermittlung im Unterricht besteht, und zwar mit Blick darauf, dass die Herausforderung für Lehrer*innen im Berufsalltag darin bestehe, „mit den Wandlungen der EU Schritt zu halten und das Repertoire an Vermittlungsansätzen zu aktualisieren und zu erweitern" (Oberle/Forstmann 2015, S. 194). Zudem wird von Seiten der Lehrer*innen die Komplexität des Gegenstands als Hauptschwierigkeit bei der Vermittlung europabezogener Themen genannt (Oberle 2015; Detjen 2004). So schlussfolgert Goll (2015), basierend auf Analysen von Lehrplänen der Fächer Gesellschaftslehre, Politik, Gemeinschaftskunde, Politik/Wirtschaft 
und Sozialwissenschaften für Schulen im Sekundarbereich, dass „Europabildung [...] nachweislich von den Lehr- und Ausbildungsplänen ernst- und wahrgenommen" wird (Goll 2015, S. 190). Dringender Bedarf zeige sich jedoch in der Fort- und Weiterbildung der Lehrer*innen, die ,,verdeckte oder unterschwellige Inhalte und Zielsetzungen in Unterrichtsmaterialien [...] erkennen" müssen (ebd., S. 190). Zusammenfassend lassen sich so drei zentrale Herausforderungen im Hinblick auf die Berücksichtigung von Europa im Unterricht identifizieren (vgl. hierzu v.a. Detjen 2004; Detjen et al. 2012; Hornberg 2010; Schöne/Immerfall 2014; Oberle 2015): Erstens gibt es zu wenig aktuelles Unterrichtsmaterial; zweitens sind die Themen zu wenig an der Lebenswelt und den Interessen der Schüler*innen orientiert und drittens mangelt es an Fortbildungen für Lehrer*innen zu Europa/EU.

\subsection{Ziele des Projekts ELIN}

Vor dem Hintergrund des skizzierten Forschungsstands und den identifizierten Leerstellen in den Bereichen der Lehrer*innenfortbildungen und Unterrichtskonzeptionen stellt sich die Frage, wie europabezogene Themen in der Schule gestärkt werden können und wie zugleich, in Anlehnung an den KMK-Beschluss von 2008 zur Europabildung, die Umsetzung einer kompetenzorientierten Unterrichtspraxis gelingen und eine entsprechende Professionalisierung der Lehrer*innen in diesem Kontext erreicht werden kann. Diesem Anliegen folgt das Projekt „Europa in der Schule - Lehrerfortbildungen in NRW“ (ELIN), mit dem das Ziel verknüpft ist, europabezogene Themen kompetenzorientiert und im Anschluss an aktuelle Kerncurricula so aufzubereiten und einzubringen, dass Lehrer*innen darin unterstützt werden, diese Themen stärker in den Unterricht gesellschafts- und sozialwissenschaftlicher Fächer zu integrieren. Das Projekt ELIN richtet sich damit an Lehrer*innen, die in der Sekundarstufe I und/oder II an Realschulen, Gesamtschulen, Berufskollegs und Gymnasien unterrichten.

\subsection{Design des Projekts}

Im Einzelnen umfasste das Projekt drei Phasen: Eine Bedarfsanalyse, die Entwicklung von Unterrichtsmodulen und die Entwicklung und Durchführung von Lehrer*innenfortbildungen sowie die wissenschaftliche Begleitforschung. Das Projekt war insgesamt auf zwei Jahre angelegt. Die drei Pro- 
jektphasen folgten zeitlich aufeinander, wobei sich Phase II und III zeitlich zum Teil überschnitten.

\subsubsection{Phase I: Bedarfsanalyse}

Um eine Stärkung sowie breitere Verankerung des Themas „Europa“ in der Schule zu ermöglichen, wurde zunächst eine Analyse der nordrheinwestfälischen Kernlehrpläne für die Fächer Geschichte, Erdkunde, Politik und Sozialwissenschaften durchgeführt. Sie erfolgte zum einen mit Bezug zu einem zuvor entwickelten Analyseraster, mit dem die Kernlehrpläne von NRW im Hinblick darauf analysiert wurden, an welchen Stellen europabezogene Themen vorkommen, zum anderen mit dem Fokus auf die folgenden vier Themenfelder: „Die EU als internationaler Akteur“, „Migration und Flucht“, „Warum Europa?“ und „Binnenmarkt". Diese vier Themenfelder wurden zu Beginn des Projekts im Austausch zwischen den Projektpartner*innen (Europäische Akademie Berlin, MSW und Technische Universität Dortmund) und einer Gruppe von Lehrer*innen mit Blick auf inhaltliche Bedarfe festgelegt und anschließend mit den Inhaltsfeldern der Kernlehrpläne abgeglichen. Auf der Grundlage der so gefilterten Inhaltsfelder und Jahrgangsstufen wurde im Projekt eine Auswahl der zu berücksichtigenden Kompetenzerwartungen für die Unterrichtsmodule vorgenommen. Insgesamt zeigte die Bedarfsanalyse, dass die gewählten thematischen Schwerpunkte eine hohe Passung mit den Vorgaben der Kernlehrpläne aufwiesen. Basierend auf dieser Bedarfsanalyse wurde die Auswahl der Themen für die Unterrichtsmodule endgültig festgelegt, so dass somit eine hohe Anschlussfähigkeit an die curricularen Vorgaben des Landes NRW gegeben ist.

\subsubsection{Phase II: Entwicklung von Unterrichtsmodulen und Entwick- lung und Durchführung von Lehrer*innenfortbildungen}

Im Anschluss an die Bedarfsanalyse wurden im weiteren Verlauf des Projekts, in Phase II, äquivalent zu den Themenfeldern insgesamt vier Unterrichtsmodule entwickelt sowie entsprechende Fortbildungsangebote konzipiert und durchgeführt.

\section{Entwicklung von Unterrichtsmodulen}

Die im Projekt entwickelten Unterrichtsmodule unterscheiden sich von Unterrichtsplanungen insofern, als dass ein Modul jeweils aus einem Vor-, Kern- und Zusatzmodul besteht und entweder vollständig oder auch nur in Teilen im Unterricht umgesetzt werden kann. Dies kann zudem entweder innerhalb einer gesamten Unterrichtsreihe oder auch anhand von Einzelelementen zum Thema Europa geschehen. Die jeweiligen Modulteile (Vor-, 
Kern- oder Zusatzmodul) fokussieren jeweils unterschiedliche Leitfragen und haben damit voneinander abgrenzbare Themenschwerpunkte, auch wenn die Themen miteinander verknüpft sind. Die Themenschwerpunkte wurden jeweils im Hinblick auf die im Modul vorrangig angesprochenen Jahrgangsstufen formuliert und an die in den Kernlehrplänen verankerten Kompetenzerwartungen angepasst. Diese modulare Struktur ermöglicht den Lehrer*innen eine Orientierung an unterschiedlichen Lerngruppen, Schulformen und Fächern. Die Module sind in einem geringen Maße fach- und jahrgangsgebunden und können auch fächerübergreifend umgesetzt werden. Der modulare Charakter soll zudem inhaltliche und methodisch-didaktische Anstöße und Ideen geben, ohne den Eindruck eines rezeptologischen Ablaufs für Unterricht zu erwecken.

In NRW, wie in anderen Bundesländern auch, bilden Kompetenzerwartungen den Schwerpunkt der Kernlehrpläne. Dies bedeutet für die Unterrichtspraxis, dass diesen Erwartungen durch die Anpassung von Lernaufgaben an die Kompetenzorientierung Rechnung getragen werden muss (Keller/ Reintjes 2016). Dem wurde im Rahmen des Projekts über die Entwicklung von kompetenzorientierten, europabezogenen Lernaufgaben nachgekommen, die den Lehrer*innen verschiedene didaktische und methodische Zugänge zum Thema offerieren und an das Niveau der Klasse individuell von der Lehrkraft angepasst und mithilfe von unterschiedlichen methodischdidaktischen Zugängen und Materialien realisiert werden können.

\section{Beispielmatrix der Unterrichtsmodule}

Fächer: Wirtschaft, Geschichte, Gesellschaftslehre | Jahrgangsstufen: 7/8/9 | KERNMODUL

Beispiel einer Leitfrage: Die EU als Wertegemeinschaft - Worum geht es in der Europäischen Union?

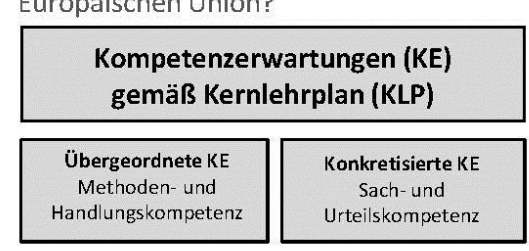

Mögliche Konkretisierung und
Zugänge
Lehrerinnen- und Lehrerhandeln,
Material, methodisch-didaktische
Gestaltung

Abbildung 1: Matrix der Unterrichtsmodule (eigene Darstellung)

Für die Darstellung der Module wurde eine Matrix gewählt (siehe Abb. 1), die als Übersicht über den jeweiligen Modulteil dient. In der Matrix wird zunächst eine Zuordnung des Modulteils (Vor-, Kern- oder Zusatzmodul) zu denjenigen Fächern und Jahrgangsstufen vorgenommen, für die der jeweilige 
Modulteil primär geeignet ist. Zusätzlich enthält die Matrix eine auf den Kernlehrplänen basierende Liste von Kompetenzerwartungen, die mithin über die Bearbeitung des jeweils vorliegenden Modulteils berücksichtigt werden können. Darüber hinaus sind in der Matrix Hinweise zur Konkretisierung und zu möglichen Zugängen zum Themenfeld (d.h. Hinweise zur methodisch-didaktischen Gestaltung und $\mathrm{zu}$ themenspezifischen Materialien) enthalten. Diese Matrix, wie sie exemplarisch in Abb. 1 dargestellt ist, diente als Grundlage für alle im Projekt entwickelten Unterrichtsmodule.

Insgesamt wurden im Rahmen des Projekts ELIN vier kompetenzorientierte Unterrichtsmodule zu den Themen (I) „Migration und Flucht", (II) „Die EU als internationaler Akteur“, (III) „Warum Europa?“ und (IV) „Binnenmarkt" entwickelt, die wie folgt zusammengefasst werden können.

(I) Das Modul „Migration und Flucht“ verfolgt das Ziel, die Schüler*innen für die Vielfalt an unterschiedlichen Biographien, Interessen und Sprachen in ihrer eigenen Lebenswelt zu sensibilisieren und zugleich ihre Auseinandersetzung mit den verschiedenen Motiven, die Menschen zur Flucht und Migration bewegen, zu stärken. Die Schüler*innen sollen die politische Situation und geographische Lage unterschiedlicher Länder kennenlernen und kritisch reflektieren können.

(II) Im Modul „Die EU als internationaler Akteur“ sollen sich die Schüler*innen mit der EU innerhalb ihres internationalen Handlungskontexts auseinandersetzen und dabei vor allem Fragen nach den Zielen der europäischen Außenpolitik, den Machtressourcen der EU sowie deren strukturelle Organisation in den Blick nehmen. Dies soll mithilfe eines Planspiels gelingen, welches unter der Leitfrage „Was will und was kann die Europäische Union außenpolitisch erreichen?" für dieses Modul entwickelt wurde.

(III) „Warum Europa?“ ist das Thema des dritten Moduls, welches das Ziel verfolgt, den Schüler*innen die vielschichtigen Aufgaben und Herausforderungen aufzuzeigen, die das Streben nach einem geeinten Europa mit sich bringt. In dem Modul soll die Frage nach dem „Warum“ aus unterschiedlichen Perspektiven beleuchtet und diskutiert werden. Dabei sollen sowohl Fragen nach politischen und wirtschaftlichen Beziehungen innerhalb des globalisierten Zeitalters als auch zugleich die Frage nach einer gemeinsamen europäischen Identität bearbeitet werden.

(IV) Das Modul „Binnenmarkt“ soll, über die wirtschaftlichen Verbindungen Europas hinaus, die Schüler*innen zu einem Verständnis von internationalen Räumen führen, indem sie nationale und internationale wirtschaftliche Prozesse und ihre Abläufe verstehen lernen. Marktprozesse, die soziale Markwirtschaft und ihre Herausforderungen durch die Globalisierung stehen dabei genauso im Mittelpunkt wie auch die Frage nach fairem Handel. 
Konzeption und Realisierung von Fortbildungen für Lehrer*innen

Neben der Konzeption von Unterrichtsmodulen war es ein weiteres Ziel des Projekts, Lehrer*innen entsprechend den Anforderungen, die anhand des anfangs skizzierten Forschungsstands hinsichtlich der Vermittlung des Themas Europa in der Schule identifiziert werden konnten, zu schulen und zu unterstützen. Als einen zentralen Baustein umfasst das Projekt daher die Entwicklung und Durchführung von Fortbildungen, die den Lehrer*innen den Zugang zu den Modulen erleichtern und sie zugleich für den Einsatz europabezogener Themen im Unterricht professionalisieren sollen. In den Fortbildungen erhielten die Lehrer*innen eingangs einen modulthemenspezifischen wissenschaftlichen Fachvortrag sowie die Möglichkeit zu einer inhaltlichen Reflexion und Diskussion. Anschließend sollten sich die Lehrer*innen vertiefend mit den Modulen auseinandersetzen und darauf aufbauend eigene kompetenzorientierte Lernaufgaben für den Unterricht erstellen. Den an den Fortbildungen teilnehmenden Lehrer*innen sollten so didaktische, methodische sowie inhaltliche Kenntnisse und Fähigkeiten für den Einsatz von europabezogenen kompetenzorientierten Lernaufgaben vermittelt werden. Eine Diskussion der erstellten Aufgaben erfolgte im Plenum und sollte den Teilnehmer*innen eine kritische Reflexion hinsichtlich des Umgangs mit kompetenzorientierten Lernaufgaben ermöglichen.

\subsubsection{Wissenschaftliche Begleitforschung}

Die wissenschaftliche Begleitforschung ist wie folgt angelegt: Zunächst erfolgt eine erste schriftliche Befragung der Lehrer*innen im unmittelbaren Anschluss an die jeweiligen Fortbildungen. Ziel dieser Befragung ist es, Erkenntnisse darüber zu erlangen, wie die Lehrer*innen die von ihnen kennengelernten Module im Hinblick auf den Einsatz in der Schul- und Unterrichtspraxis beurteilen. Die Ergebnisse dieser Befragungen wurden dann im Projekt dazu genutzt, die Module unter Berücksichtigung der Rückmeldungen der Lehrer*innen weiterzuentwickeln. Im Folgenden werden Ergebnisse dieses Projekts vorgestellt.

Insgesamt konnten Daten von 98 Lehrer*innen aus NRW gewonnen werden, die zusammengenommen aus sechs verschiedenen Lehrer*innenfortbildungen und anschließenden Erhebungen stammen. Der eingesetzte Fragebogen enthielt sowohl geschlossene als auch offene Fragen.

Die Auswertung der Fragebögen zeigt, dass die befragten Lehrer*innen alle vier Module für im Unterricht einsatzfähig halten. Insbesondere die Module „Warum Europa?“ und „Migration und Flucht“" wurden von den Lehrer*innen als geeignet eingestuft, um das Interesse der Schüler*innen an Europa bzw. der EU zu stärken. Im Rahmen der Auswertung wurden die Lehrer*innen mittels offener Fragen danach gefragt, welche Aspekte der von 
ihnen kennengelernten Module sie für eine Umsetzung im Unterricht als besonders geeignet und welche sie hinsichtlich einer Umsetzung als schwieriger empfinden. Die Antworten wurden im Rahmen einer qualitativen Inhaltsanalyse (Kuckartz 2016) mittels induktiver Kategorienbildung zusammengefasst und nach der Häufigkeit der Nennungen sortiert.

Bezogen auf das in den Modulen bereitgestellte Material wurden folgende Aspekte als positiv bewertet: Die Gestaltung und die Qualität sowie die Aktualität und der Lebensweltbezug der Materialien. Mit Blick auf die Schüler*innen wurden die Schüler*innenorientierung, die Motivation der Schüler*innen sowie die emotionale Einbindung der Schüler*innen positiv hervorgehoben. In Bezug auf die Lernaufgaben wurden die folgenden Aspekte positiv herausgestellt: Die Kompetenzorientierung und die Handlungs- und Problemorientierung sowie die kreativen, abwechslungsreichen und vielfältigen methodisch-didaktischen Zugänge. Als mögliche Schwierigkeiten nannten die Lehrer*innen eine punktuelle Komplexität und Textlastigkeit der Materialien, die nach ihrer Einschätzung zum Teil zu viel Vorwissen auf Seiten der Schüler*innen voraussetzen.

Insgesamt können, auch unter Rückbezug auf den anfangs skizzierten Forschungsstand, die Themenfelder der im Projekt erarbeiteten Module und Fortbildungen als Antworten auf die zentralen Anforderungen, die im Hinblick auf die Berücksichtigung von Europa im Unterricht identifiziert werden konnten, gesehen werden. Die in den Modulen berücksichtigte Kompetenzorientierung der Lernaufgaben, die Aktualität der Themen sowie die vielfältige Einsetzbarkeit der Module und Modulteile können als Weg angesehen werden, der oft bemängelten reinen Institutionenkunde (Frech et al. 2014) zu begegnen und den Lehrer*innen ein abwechslungsreiches, am Curriculum orientiertes Material zur Verfügung zu stellen. Mit den im Projekt konzipierten und durchgeführten Fortbildungen konnte zudem dem Bedarf einer Professionalisierung der Lehrer*innen im Kontext der Vermittlung europabezogener Themen begegnet werden und die Lehrer*innen konnten zum Austausch und zu einer kritischen sowie professionalisierungsorientierten Reflexion angeregt werden.

\subsection{Abschließende Bemerkungen und Ausblick}

Das Projekt ELIN zielte darauf, europabezogene Themen stärker in Schule und Unterricht zu verankern. Eine Möglichkeit für eine solche Stärkung ist die Veränderung bzw. Erweiterung unterrichtlicher Praxis, die vor allem von Lehrer*innen angestoßen werden muss. Lehrer*innenfortbildungen, die offene und zugleich leicht konkretisierbare Hinweise und Ideen für Unterrichtskonzeptionen beinhalten sowie den Lehrer*innen kenntnisreiche inhaltliche 
Denk- und Reflexionsanstöße bieten, sind daher als zentraler Wirkungsort des Projekts ausgewählt worden. Die im Projekt durchgeführten Analysen haben gezeigt, dass die Inhaltsfelder und Kompetenzerwartungen der nordrhein-westfälischen Kernlehrpläne an vielen Stellen Anknüpfungspunkte und Bezüge zum Thema Europa aufweisen und daher eine breitere Verankerung der Auseinandersetzung mit europabezogenen Themen im Unterricht möglich machen.

Die Rückmeldungen der Lehrer*innen im Anschluss an die Fortbildungen verdeutlichen, dass die Arbeit an und mit den Modulen sowie die Teilnahme an wissenschaftlichen Fachvorträgen von den Lehrer*innen als interessant und notwendig beschrieben werden, u.a. um den Abstraktionsgrad des Themenfelds „Europa“ zu verringern; ferner wurde ein Bedarf an regelmäßigen Fortbildung zum Thema Europa deutlich.

Die hier vorgestellten Erfahrungen und Ergebnisse aus dem Projekt zeigen, dass es hinsichtlich der Vermittlung von Europa und der Verankerung des Themas im Unterricht verschiedene Zugänge gibt und dass Lehrer*innen ein Interesse daran haben, solche Zugänge kennenzulernen, mitzuentwickeln und auszuarbeiten. Es bleibt jedoch abzuwarten, inwieweit der Einsatz der Module im Unterricht dafür geeignet ist, auch auf längere Sicht der Komplexität Europas und der Vielschichtigkeit der mit dem Konstrukt Europa zusammenhängenden Institutionen zu begegnen. Interessant wird es hier sein, zu erfahren, ob der Unterricht auf Grundlage der in diesem Projekt entwickelten Module dazu beitragen kann, das Interesse am sowie die Beschäftigung mit dem Thema Europa/EU auf Seiten der Schüler*innen zu intensivieren und wie die Berücksichtigung von Europa von den Lehrer*innen in der Unterrichtspraxis gestaltet wird.

Die globalen Verhältnisse, die sie prägenden Verwobenheiten und Abhängigkeiten bringen komplexe Fragen und Anforderungen mit sich, welchen Lehrer*innen nur durch kontinuierliche inhaltliche Auseinandersetzungen und Reflexionen und mit einem breiten Wissen über Europa/EU und den damit zusammenhängenden Themenbereichen begegnen können. Der Forschungsstand sowie die ersten Ergebnisse des hier vorgestellten Projekts machen deutlich, dass die Professionalisierung der Lehrer*innen und die Schule einen wichtigen Beitrag zur Bearbeitung zentraler Fragen im Hinblick auf europabezogene Themen leisten können.

\section{Literatur}

Detjen, J. (2004): Europäische Unübersichtlichkeiten. Wie soll die politische Bildung mit der Kompliziertheit und Intransparenz der Europäischen Union umgehen? In: 
Weißeno, G. (Hrsg.): Europa verstehen lernen. Eine Aufgabe des Politikunterrichts. Bonn: Bundeszentrale für politische Bildung, S. 126-143.

Detjen, J./Massing, P./Richter, D./Weißeno, G. (2012): Politikkompetenz - ein Modell. Wiesbaden: Springer.

Frech, S./Kalb, J./Templ, K.-U. (2014): Einführung: Europa in der Schule. In: Frech, S./Kalb, J./Templ, K.-U. (Hrsg.): Europa in der Schule. Perspektiven eines modernen Europaunterrichts. Schwalbach/Ts.: Wochenschau Verlag, S. 14-31.

Goll, T. (2015): Besondere Schwierigkeiten bei der Vermittlung der EU in der Politischen Bildung? In: Oberle, M. (Hrsg.): Die Europäische Union erfolgreich Vermitteln. Wiesbaden: Springer VS, S. 179-192.

Hornberg, S. (2010): Schule im Prozess der Internationalisierung von Bildung. Studien zur International und Interkulturell Vergleichenden Erziehungswissenschaft, Bd. 11. Münster: Waxmann.

Hornberg, S./Sonnenburg, N. (2017): Empirische Befunde zu Europaschulen in Nordrhein-Westfalen. In: ZEP - Zeitschrift für Internationale Bildungsforschung und Entwicklungspädagogik 40(4): 13-16.

Janssen, B. (1986): Europa in der Schule: zur politischen Bildung in der Bundesrepublik Deutschland, in Dänemark, Frankreich, Großbritannien und den Niederlanden. Bonn: Europa Union.

Keller, S./Reintjes, C. (2016): Aufgaben als Schlüssel zur Kompetenz: eine Einleitung. In: Keller, S./Reintjes, C. (Hrsg.): Aufgaben als Schlüssel zur Kompetenz. Didaktische Herausforderungen, wissenschaftliche Zugänge und empirische Befunde. Münster: Waxmann, S. 15-25.

Kuckartz, U. (2016): Qualitative Inhaltsanalyse. Methoden, Praxis, Computerunterstützung (3., durchgesehene Aufl.). Weinheim: Beltz Juventa.

Kultusministerkonferenz (2008): Europa in der Schule. Empfehlung der Ständigen Konferenz der Kultusminister der Länder in der Bundesrepublik Deutschland. Beschluss der Kultusministerkonferenz vom 08.06.1978 i. d. F. vom 05.05.2008. https://www.kmk.org/fileadmin/Dateien/veroeffentlichungen beschluesse/1978/1 978_06_08_Europabildung.pdf [Zugriff: 30.11.2016].

Lawn, M./Grek, S. (2012): Europeanizing Education: governing a new policy pace. Oxford: Symposium Books Ltd.

Natterer, A. (2001): Europa im Schulbuch: Die Darstellung der europäischen Einigung in baden-württembergischen Schulbüchern für Geschichte und Gemeinschaftskunde der Sekundarstufe I. Grevenbroich: Omnia.

Oberle, M. (2012): Politisches Wissen über die Europäische Union. Subjektive und objektive Politikkenntnisse von Jugendlichen. Wiesbaden: Springer VS.

Oberle, M. (Hrsg.) (2015): Die Europäische Union erfolgreich vermitteln. Perspektiven der politischen EU-Bildung heute. Wiesbaden: Springer VS.

Oberle, M./Forstmann, J. (2015): Lehrerfortbildungen zur politischen EU-Bildung eine empirische Begleitstudie. In: Oberle, M. (Hrsg.): Die Europäische Union erfolgreich vermitteln. Wiesbaden: Springer VS, S. 193-209.

Rappenglück, S. (2014): Europabezogenes Lernen. In: Sander, W. (Hrsg.): Handbuch politische Bildung (4., völlig überarbeitete Aufl.). Schwalbach/Ts: Wochenschau, S. 392-400.

Schöne, H./Immerfall, S. (2014): EU unterrichten - Widersprüche im Schulalltag. In: Frech, S./Kalb, J./Templ, K.-U. (Hrsg.): Europa in der Schule. Perspektiven eines modernen Europaunterrichts. Schwalbach/Ts.: Wochenschau Verlag, S. 54-66. 
Schöne, H./Immerfall, S. (2015): EU-Bildung in der Schule - Erfahrungen und Desiderate. In: Oberle, M. (Hrsg.): Die Europäische Union erfolgreich vermitteln. Wiesbaden: Springer VS, S. 67-80.

Tham, B. (2006): Einstellungen, Erwartungen und Befürchtungen Jugendlicher gegenüber der Europäischen Union und ihrer Politik im Jahr 2005 - Analyse, Bewertung und Perspektiven. https://www.jugendpolitikineuropa.de /downloads/420-2246/2006_Einstellungen.pdf [Zugriff: 14.03.2018].

Tömmel, I. (2008): Das politische System der EU (3., vollständig überarbeitete Aufl.). München: Oldenbourg Wissenschaftsverlag. 


\title{
10 Europäisierungsprozesse als Reformchance? Eine institutionelle Analyse der \\ Durchlässigkeitsstrukturen zwischen Berufs- und Hochschulbildung in Deutschland von 1990-2012 ${ }^{1}$
}

\author{
Nadine Bernhard
}

\subsection{Einleitung}

Mit der Verabschiedung der UN-Nachhaltigkeitsziele 2016 wurde im vierten Ziel unterstrichen, wie wichtig es ist, inklusive und qualitativ hochwertige Bildung ein Leben lang zu ermöglichen. Lebenslanges Lernen für Alle bedarf allerdings Bildungssysteme, die durchlässig sind, so dass an bereits Gelerntes immer wieder angeknüpft werden kann. Die Frage nach dem Wandel institutioneller Durchlässigkeitsstrukturen stellt sich umso stärker, da auch europäische Bildungsprozesse, der Bologna-Prozess für die Hochschulbildung und der Kopenhagen-Prozess für die berufliche Bildung, Durchlässigkeit zwischen beruflicher und akademischer Bildung fordern und zu implementierende Standards wie Leistungspunktesysteme oder Modularisierung anbieten (Bernhard 2017a).

Der Bologna-Prozess startete 1999 offiziell mit der Bologna-Erklärung und zielt auf die Schaffung eines europäischen Hochschulraumes, einer Erhöhung der Mobilität Studierender und Lehrender und eine größere Vergleichbarkeit der Abschlüsse. Mittlerweile beteiligen sich 48 Mitgliedstaaten an dem Prozess. Der Kopenhagen-Prozess begann 2002 und hat seit der Riga Conclusion 201536 beteiligte Mitgliedstaaten. Hauptziele sind die Stärkung der Vergleichbarkeit der beruflichen Bildung und die Erhöhung der Arbeitsmobilität sowie der sogenannten ,employability“ der Lernenden über Strukturen des Lebenslangen Lernens (Powell et al. 2012). Allgemein zielen die

1 Dieser Beitrag beruht zu großen Teilen auf meiner Dissertation (Bernhard 2017a, 2017b), die im Rahmen des DFG-Projekts ,Internationalization of Vocational and Higher Education Systems in Transition“ (INVEST) entstand. 
intergouvernementalen Bologna- und Kopenhagen-Prozesse auf die Standardisierung und Stärkung der Hochschul- und Berufsbildung.

Vor diesem Hintergrund soll in diesem Beitrag gezeigt werden, welchen Einfluss die europäischen Bildungsprozesse Bologna und Kopenhagen in Hinblick auf die Entwicklung institutioneller Durchlässigkeitsstrukturen in Deutschland hatten. Veränderungen in diesen Strukturen können dabei mit vielfältigen Implikationen für die Bildungs- und soziale Mobilität einhergehen (Bernhard 2017a), denn stratifizierte (Aus-)Bildungssysteme ohne Brücken zwischen einzelnen Bildungsbereichen behindern den möglichst gleichen Zugang zu Bildungs- und Beschäftigungsopportunitäten.

Insbesondere Länder, deren Bildungssysteme sich wie in Deutschland durch eine starke Segmentierung zwischen Berufs- und Hochschulbildung (Baethge 2006; Baethge/Wolter 2015) auszeichnen, stehen somit vor großen Herausforderungen. Die gewachsenen Strukturen in Deutschland hemmen Bildungszu- und -übergänge von einem Bereich in den anderen ebenso wie die Anrechnung und Anerkennung des Gelernten. Verstärkt wird die Trennung zudem durch das stratifizierte und stark segregierte Schulsystem (Powell/Solga 2011). Der Weg zur Hochschule führt primär über die allgemeinbildenden höheren Sekundarschulen (oft Gymnasien) mit dem Abschluss des Abiturs. Die Abschlüsse der unteren Sekundarstufe münden in die berufliche Bildung. Insofern stellt sich die Frage, inwiefern konnten Europäisierungsprozesse auch als Chance genutzt werden, um die deutsche traditionelle Trennung zwischen Berufs- und Hochschulbildung zu verringern und Übergänge zu erleichtern?

Um diese Frage zu beantworten, wird in einem ersten Schritt das Verständnis von Durchlässigkeit geklärt und die theoretische Anlage des Beitrags dargestellt. Nachfolgend wird das Forschungsdesign skizziert, die Entwicklungen in Deutschland im Verhältnis zu den europäischen Vorgaben dargestellt sowie abschließend der Einfluss der europäischen Prozesse analysiert.

\subsection{Begriffliche und theoretische Konzeptualisierungen}

Dieser Abschnitt dient der Verständigung über den Begriff Durchlässigkeit sowie der theoretischen Verortung des Beitrages. 


\subsubsection{Durchlässigkeitskonzept}

Während der Fokus auf soziale Durchlässigkeit individuellen Aufstieg und soziale Mobilität in den Blick nimmt, stehen bei der Analyse institutioneller Durchlässigkeit die institutionelle Ausgestaltung des Bildungssystems im Vordergrund. Konzeptionell umfasst institutionelle Durchlässigkeit nach Bernhard (2017a) vier analytisch getrennte Aspekte.

Erstens sind Fragen des Zugangs eng verknüpft mit der Gestaltung eines durchlässigen Bildungssystems. Zugang kann ganz unterschiedlich geregelt sein: möglich wäre a) ein unbeschränkter Zugang, b) ein Zugang über ein Berechtigungssystem, wie die deutsche Hochschulzugangsberechtigung oder c) über Entscheidungen der aufnehmenden Organisation. Eignungstests oder -gespräche wären Beispiele für entsprechende Zulassungsverfahren. Durchlässigkeit kann so erhöht werden insbesondere für Personen, die formale Berechtigungen nicht besitzen, aber dank individuell gezeigter Leistung doch Zugang finden.

Zweitens ist Durchlässigkeit auch verbunden mit Fragen der Anrechnung von Gelerntem. Zentral ist hier die Annahme, dass verschiedene Lernwege zu gleichwertigen Kompetenzen und Kenntnissen führen und folglich auch als gleichwertig behandelt werden können (Freitag et al. 2011). Wie und wo etwas gelernt wurde, verliert dadurch an Bedeutung.

Drittens kann Durchlässigkeit auch über die organisationale Verbindung von Bildungsbereichen ermöglicht werden (Bernhard 2017a). Zum einen ist dies denkbar über institutionalisierte konsekutive Verbindungen von einem Bildungsgang zum nächsten. Zum anderen umfasst dieser Aspekt die Integration von unterschiedlichen Bildungsbereichen in einer Organisation oder einem Bildungsgang (vgl. auch Euler/Severing 2015). Das duale Studium in Deutschland, das alternierend akademische Bildungs- und berufliche Praxisphasen im Betrieb anbietet (vgl. Graf 2013), wäre ein Beispiel. Durchlässigkeit wird hier gefördert, indem Barrieren in Form von typischen Logiken, Idealen und Normen der Bildungsbereiche aufgebrochen werden.

Der vierte Aspekt von Durchlässigkeit umfasst schließlich Strukturen, die sich mit Fragen des Umgangs mit heterogenen Bedürfnissen von Lernenden beschäftigen (Bernhard 2017a). Im Zentrum steht die Unterstützung der Lernenden durch eine Vielzahl von Elementen: wie Informations- und Beratungsstrukturen (Banscherus et al. 2015), die Sicherung der Finanzierung (Mucke/Kupfer 2011), die Art und Weise, wie Lernen organisiert wird z.B. durch Flexibilisierung über ein Teilzeitstudium, aber auch eine Veränderung der Pädagogik. Allgemein bedarf es der Akzeptanz von Heterogenität auf allen Ebenen der Bildungsorganisation und damit eine Etablierung einer Kultur der Offenheit gegenüber der Diversität von Lernenden. 
Durchlässigkeit bedeutet damit schließlich nicht nur die Ermöglichung von Zugang und Anrechnung, sondern umfasst auch ein erfolgreiches Absolvieren des Bildungsgangs.

\subsubsection{Institutionen, Diskurse und "Goodness of Fit"}

Nachfolgend wird das interdisziplinäre theoretische Gerüst der Untersuchung dargestellt.

Dieser Beitrag folgt dem Institutionenverständnis nach Scott (2008) und unterscheidet regulative, normative und kulturell-kognitive institutionelle Dimensionen von Institutionen. Regulative Elemente beschränken Handlungen durch gesellschaftliche Regeln und werden über Zwang durchgesetzt. In dieser Analyse werden gesetzliche Veränderungen der Durchlässigkeitsstrukturen untersucht. Die normative Dimension umfasst Normen, Werte und Standards, welche über den Mechanismus von (moralischer) Verpflichtung durchgesetzt werden. Wege, wie das als normativ wertvoll Bewertete erreicht werden soll, sind somit Teil der normativen Dimension (Scott 2008, S. 56). Die Institutionenanalyse in diesem Beitrag fragt danach, welche Normen und Standards in Bezug auf Durchlässigkeit existieren. Die kulturell-kognitive Dimension betont schließlich geteilte Vorstellungen der sozialen Wirklichkeit, gemeinsame Glaubens- bzw. Bedeutungssysteme, die sich über den Mechanismus der Selbstverständlichkeit durchsetzen (Scott 2008). Analysiert werden demnach Vorstellungen, Argumentationen und das Verständnis von Durchlässigkeit.

In Verbindung mit der wissenssoziologischen Diskursanalyse (Keller 2008a) wird die kulturell-kognitive und normative institutionelle Dimension dabei in der Bedeutungskonstruktion von Durchlässigkeit auf der Ebene der diskursiven Praktiken sozialer Akteure analysiert. Diskurse werden als ,geregelte Praktiken der Deutungsproduktion und Wirklichkeitskonstruktion“ verstanden, durch die gesellschaftliche Wissensvorräte entstehen (Keller 2006, S. 125). Die gesellschaftlichen Wissensvorräte müssen dabei konzipiert werden als sich in ständiger Bewegung befindend und als untereinander in Konkurrenzbeziehungen stehend. Durch die diskursanalytische Perspektive gelangt die Transformation gesellschaftlicher Definitionsverhältnisse von Durchlässigkeit damit in den Fokus, da analysiert wird, wie bildungspolitische Akteure in Deutschland Durchlässigkeit verstehen, konstruieren und rekonzeptualisieren (Bernhard 2017a). In Deutschland können demnach die europäischen Bildungsprozesse in Diskursen als Bestätigung bestehender symbolischer Ordnungen interpretiert werden, oder aber zum Anlass für Änderungen gemacht werden.

In der politikwissenschaftlichen Literatur zur Europäisierung wird die Wirkmächtigkeit europäischer Vorgaben als abhängig vom sogenannten 
„goodness of fit“" gesehen. Dieser Ansatz, der primär im Bereich der positiven Integration verwendet wurde (Auel 2006), besagt, dass je größer die Diskrepanz zwischen den europäischen Vorgaben und Standards und dem nationalen Status quo, desto größer der Handlungsdruck auf die Länder und desto wahrscheinlicher auch der europäische Einfluss (Börzel/Risse 2003). Die europäischen Bildungsprozesse Bologna und Kopenhagen sind zwar nicht Teil der supranationalen Politiksetzung der EU, allerdings wurde gezeigt, dass durch sie auch normativer Druck auf die Nationalstaaten ausgehen kann, zumal die vereinbarten Standards kontinuierlich geprüft werden (z.B. Ravinet 2008). Zugleich sind es eben solche Prozesse der Aushandlung und der gegenseitigen Vergleiche, die zur Diffusion von Ideen und Argumentationslogiken führen und die Übernahme von Standards anregen und nationale Lernund Sozialisationsprozesse beeinflussen können (Radaelli 2000, S. 19).

\subsection{Methode}

Um Wandel und den möglichen Einfluss europäischer Prozesse zu untersuchen, wurde eine Mehrebenenanalyse unter Verwendung verschiedener methodischer Ansätze und Datenquellen für zwei Untersuchungszeiträume durchgeführt. Der erste Zeitraum beginnt 1990 und endet 1998, während der zweite Zeitraum mit dem Beginn des Bologna-Prozesses 1999 startet und 2012 endet. Auf diese Weise kann die Entwicklung vor und nach dem Beginn der Europäisierungsprozesse verglichen werden.

Im Zentrum der Analyse der normativen und kulturell-kognitiven Dimension der institutionellen Durchlässigkeitsstrukturen stehen die bildungspolitischen Diskurse zu Durchlässigkeit in Deutschland. Analysiert wurden 144 bildungspolitische Dokumente in Form von Stellungnahmen, Positionspapieren, Pressemitteilungen, protokolierten Reden bzw. Beiträgen in Bundestagsausschüssen von den Organisationen, die die Steuerung in den Feldern der Berufs- und Hochschulbildung in Deutschland mit am stärksten mitbestimmen und den koordinativen Diskursraum bilden (Schmidt 2008): das Bundesministerium für Bildung und Forschung (BMBF) und die Kultusministerkonferenz (KMK) als Vertretung der staatlichen Steuerung, die Hochschulrektorenkonferenz als Interessenvertretung des Hochschulbereichs, der Deutschen Gewerkschaftsbund (DGB) und der Deutsche Industrie- und Handels- 
kammertag (DIHK) als wichtige Vertreter der Arbeitgeber*innen und -nehmer*innen ${ }^{2}$.

Die bildungspolitischen Dokumente wurden mithilfe der wissenssoziologischen Diskursanalyse nach Keller (2008a) untersucht. Sowohl die Dokumentenauswahl für die Feinanalyse als auch die Analyse dieser erfolgte Keller (2008a, 2008b) folgend, angelehnt an Verfahren der Grounded TheoryMethodologie nach Strauss und Corbin (1996).

Die regulativen Änderungen wurden über Sekundärliteratur und mithilfe der Analyse von Rechtsdokumenten unter Verwendung der Durchlässigkeitsheuristik untersucht. Analysiert wurden das Hochschulrahmengesetz, Landeshochschulgesetze, KMK-Beschlüsse sowie das Berufsbildungsgesetz.

Um den Einfluss der europäischen Prozesse zu untersuchen, musste zudem analysiert werden, inwiefern diese Prozesse Anforderungen in Bezug auf institutionelle Durchlässigkeit an die nationalen Bildungssysteme formulieren. Dies erfolgte über eine theoriegeleitete qualitative Inhaltsanalyse nach Gläser/Laudel (2006) der 14 Deklarationen und Kommuniqués der Bolognaund Kopenhagen-Prozesse ${ }^{3}$.

Da aber ein Angleichen von nationalen Strukturen an europäische Vorgaben nicht gleichzusetzen ist mit europäischem Einfluss, wurde in einem letzten Schritt einerseits der deutsche Durchlässigkeitsdiskurs auf Bezüge zu den europäischen Prozessen untersucht und andererseits auch Expert*inneninterviews durchgeführt. Mitarbeiter*innen folgender Organisationen wurden interviewt: das Bundesinstitut für Berufsbildung (BIBB), das Bundesministerium für Bildung und Forschung (BMBF) sowie die Hochschulrektorenkonferenz (HRK). Insgesamt wurden sieben qualitative teilstandardisierte Leitfadeninterviews mit acht Expert*innen geführt. Die Auswertung erfolgte in Anlehnung an die Bearbeitungsphasen von Meuser und Nagel (2009) und integrierte das inhaltsanalytische Vorgehen nach Gläser und Laudel (2006, S. 56f.). Die Kombination der Untersuchung von Diskursen und Expert*inneninterviews ist notwendig, da politische Akteure (in ihren Stellungnahmen) nicht immer artikulieren, dass Reformen durch exogene Kräfte beeinflusst werden und damit quasi ,silent borrowing“ (Waldow 2009, S. 478) möglich sein kann. Die Annahme ist, dass Expert*inneninterviews diese Prozesse eher offenbaren.

2 Eine ausführliche Beschreibung des Vorgehens der Analyse und des Dokumentensamplings sowie die Liste aller untersuchten Dokumente kann in Bernhard (2017a) sowie im dazugehörigen Dokumentenanhang (Bernhard 2017b) nachgelesen werden.

3 Sorbonne Declaration (1998); Bologna Declaration (1999); Prague Communiqué (2001); Berlin Communiqué (2003); Bergen Communiqué (2005); London Communiqué (2007); Leuven/Louvain-la-Neuve Communiqué (2009); Budapest/Vienna Declaration (2010), Bucharest Communiqué (2012) für den Bologna-Prozess sowie Copenhagen Declaration (2002); Maastricht Communiqué (2004); Helsinki Communiqué (2006); Bordeaux Communiqué (2008) und das Bruges Communiqué (2010) für den Kopenhagen-Prozess. 


\subsection{Entwicklung der Durchlässigkeitsstrukturen in Deutschland und der Einfluss von Europäisierungsprozessen}

Zur Beantwortung der Frage nach dem Einfluss von Bologna und Kopenhagen soll im Folgenden in einem ersten Schritt dargestellt werden, wie hoch die goodness of fit zwischen europäischen Vorgaben und deutschen Durchlässigkeitsstrukturen war und wie sich die Passung nach dem Beginn der Bologna- und Kopenhagen-Prozesse entwickelt hat. Dabei werden die Konzeptionen von Durchlässigkeit und die Argumentationen, warum Durchlässigkeit als (nicht) notwendig wahrgenommen wird (kulturell kognitive Dimension), verglichen. Anschließend erfolgt der Vergleich der geforderten europäischen Standards (normative Dimension) mit den diskursiven und rechtlichen Entwicklungen in Deutschland. Zuletzt wird der Frage nach dem wahrgenommenen Einfluss der Prozesse nachgegangen.

\subsubsection{Konzeption von Durchlässigkeit und Argumentationsstrukturen im deutsch-europäischen Vergleich}

Durch die Analyse der Bologna- und Kopenhagen Prozesse konnte erarbeitet werden, dass das Verständnis und die geforderten Standards sich in beiden Prozessen weitgehend ähneln, so dass nachfolgend von einem europäischen Durchlässigkeitsmodell gesprochen wird. Unterschiede gab es dahingehend, dass die Frage nach Durchlässigkeit deutlich intensiver im Kopenhagen Prozess thematisiert wurde und erst viel später an Relevanz im Bologna-Prozess gewann (Bernhard 2017a).

Wie aber wurde Durchlässigkeit konstruiert, welche Aspekte waren relevant? In den europäischen Dokumenten wurden alle vier Aspekte thematisiert, wobei der Schwerpunkt auf Fragen des Zugangs und der Anrechnung lagen. Organisationale Verbindungen von beruflichen Phasen und akademischer Bildung im Hochschulsystem wurden verstärkt im KopenhagenProzess gefordert. In beiden wurden Strukturen thematisiert, die die Bedürfnisse der Lernenden unterstützen, z.B. verstärktes studierendenzentriertes Lernen oder Beratungs-und Informationssysteme.

In Deutschland zeigte sich eine deutliche Erweiterung des Durchlässigkeitsverständnisses in den bildungspolitischen Diskursen im Vergleich der 
beiden Zeiträume. Im ersten Zeitraum (1990-1998) wurde Durchlässigkeit vor allem im Zusammenhang mit Fragen des Zugangs und der Schaffung organisationaler Verbindungen in Form von Dualen Studiengänge diskutiert. In der Zeit nach 1999 wurde dagegen nicht mehr primär gefragt, ob beruflich Qualifizierte Zugang erhalten sollten, sondern vielmehr wer genau Zugang bekommt und wer dies entscheidet. Neu war zudem auch, dass Durchlässigkeit auch Anrechnung bedeutet. Es wurde demnach anerkannt, dass gleichwertige Kompetenzen in Berufs- und Hochschulbildung erworben werden können. Zudem wird drittens durch die größere Selbstverständlichkeit einer neuen Gruppe von Studierenden, problematisiert, dass bestimmte Strukturen, die bisher auf die traditionellen aus den Gymnasien graduierten jungen Vollzeitstudierenden ausgerichtet sind, nur unzureichend den Bedürfnissen beruflich Qualifizierter entsprechen. Ein besserer Umgang mit der Heterogenität der Bildungsteilnehmer*innen wird also als notwendig angesehen.

Das übergeordnete Ziel in den deutschen Diskursen vor 1999 war es, durch eine Steigerung der Attraktivität der Berufsbildung mehr Individuen für eine Ausbildung zu interessieren, da ein Facharbeitermangel befürchtet wurde (BMBW 1992; DIHT 1992). Nach 1999 wurde immer mehr ein durch den Strukturwandel hervorgerufener Fachkräftemangel in der akademischen Bildung als Problem angesehen. D.h. das Ziel war nun insgesamt mehr Individuen für ein Studium zu motivieren. Dieses Ziel war auch das dominante in den europäischen Dokumenten.

Allerdings war in Deutschland die Debatte um Durchlässigkeit deutlich umkämpft, indem sich in beiden Zeiträumen ein strukturkritischer und -konservativer Diskurs gegenüberstanden. Letzterer plädiert für das Beibehalten der Trennung. Durchlässigkeit wird primär als eine Gefahr für die Qualität der Hochschulbildung und potentielle Ressourcenverschwendung konstruiert, die durch die vermeintlich fehlende Studienbefähigung beruflich Qualifizierter entsteht.

„Der Druck zur Deregulierung des Zugangs zum Hochschulbereich würde so groß, dass realistische Anforderungen an die Vorqualifikation aus dem Blick geraten und Studierende wie Hochschulen überfordert würden. Notwendige Nachqualifikationen wären nicht leistbar und das Qualitätsniveau von Lehre und Studium müsste sinken.“ (HRK 2010)

Der strukturkritische Diskurs, der im Vergleich der Untersuchungszeiträume dominanter wurde, favorisiert größere Durchlässigkeit. In ihm wird einerseits auf Basis stärker universalistischer Begründungen wie dem Recht auf Bildung und dem Ziel der Chancengleichheit und Gleichwertigkeit argumentiert.

„Die Durchlässigkeit am Übergang zur Hochschule ist damit nicht nur eine Maßnahme zur Ausschöpfung des Potenzials an Wissen in einem rohstoffarmen Land, sie fördert ebenso die Chancengleichheit der Qualifizierungswege: Allgemeinbildung und Berufsbildung, die Gleichwertigkeit von allgemeiner und beruflicher Bildung." (KMK 2009, S. 2) 
Andererseits werden funktionalistische Argumentationen genutzt, in denen Durchlässigkeit als funktionales Erfordernis für die Arbeitswelt konstruiert wird, denn der strukturelle, technologische und demografische Wandel erfordere, dass die Individuen sich lebenslang beruflich oder akademisch weiterbilden, was über ein durchlässiges Bildungssystem ermöglicht werden kann

„Denn die neue Arbeitswelt verlangt eine erhöhte Durchlässigkeit der Bildungswege, da die Erwerbsbiografien völlig neue Muster einnehmen. [...] Und schließlich kommt aufgrund der Alterung der Belegschaften auf die deutsche Erwerbsbevölkerung ein Engpass an Arbeitskräften hinzu, wodurch eine Wiederaufnahme von Qualifikationswegen in der zweiten Hälfte der Erwerbsbiografie häufiger erforderlich wird.“ (DIHK 2007)

Mit ganz ähnlichen Argumentationen lässt sich der strukturkritische Diskurs auch in den europäischen Dokumenten wiederfinden, wobei hier noch deutlicher als im deutschen Fall funktionalistische Gründe überwiegten (Bernhard 2018). Allerdings ist in den europäischen Dokumenten kein Gegendiskurs identifizierbar. Der Bedarf von Durchlässigkeit zwischen Berufs- und Hochschulbildung wird nicht in Frage gestellt.

\subsubsection{Umsetzung europäischer Standards}

Welche Standards wurden auf europäischer Ebene gefordert und inwiefern wurden diese in Deutschland regulativ umgesetzt oder zumindest in den Bildungsdiskursen thematisiert?

Die nachfolgend aufgeführten Standards sind die wichtigsten, die in den europäischen Prozessen als unterstützend für eine Durchlässigkeit zwischen Berufs- und Hochschulbildung thematisiert wurden. Die geforderten Standards Leistungspunktesysteme, Lernergebnisorientierung, Qualifikationsrahmen und Verfahren der Anerkennung und Validierung von vorgängigem Lernen sind eng mit dem Aspekt der Ermöglichung von Anrechnung verbunden, können aber auch Zugang erleichtern. Die europäischen Standards der Flexibilisierung des Bildungsangebots und Beratungs- und Unterstützungsstrukturen zielen auf den verbesserten Umgang mit Heterogenität.

In Tabelle 1 wird ersichtlich, dass in Deutschland eine enorme Angleichung der regulativen und diskursiven Strukturen an die europäischen Vorgaben im Vergleich der Zeiträume stattfand. Im ersten Zeitraum bis 1998 zeigte sich, dass außer der Integration berufspraktischer Elemente an Hochschulen (in Form von dualen Studiengängen) keine der geforderten Standards rechtlich institutionalisiert waren und auch wenig bis gar nicht in den Diskursen thematisiert wurden. Im Verlauf des zweiten Zeitraums wurden Leistungspunktesysteme an den Hochschulen eingeführt, Teilzeitstudienmöglichkeiten in den Landeshochschulgesetzen festgeschrieben, duale Studiengänge ausgebaut, der nationale Qualifikationsrahmen entwickelt und 2012 eingeführt. Zugleich wurden die Studiengänge und zum Teil auch die Ausbildun- 
gen lernergebnisorientiert umstrukturiert, Verfahren der Anrechnung außerakademischer Kompetenzen wurden gesetzlich festgeschrieben (KMK 2002), wobei es aber keine standardisierten bundesweit geltenden Verfahren gibt und die Praxis sich von Hochschule zu Hochschule unterscheidet (Banscherus et al. 2016). Unterstützungs- und Beratungsstrukturen wurden zum Ende des zweiten Zeitraums in den Diskursen wichtiger, wobei 2008 zum Beispiel mit dem Aufstiegsstipendium für beruflich Qualifizierte an Hochschulen auch gewisse Unterstützungsstrukturen regulativ festgeschrieben wurden.

Tabelle 1: Umsetzung europäischer Standards in Deutschland (eigene Darstellung)

\begin{tabular}{|l|l|l|l|}
\hline Europäische Standards & Aspekte & $\mathbf{1 9 9 0 - 1 9 9 8}$ & $\mathbf{1 9 9 9 - 2 0 1 2}$ \\
\hline Lernergebnisorientierung & Zugang, Anrechnung & - & $\mathbf{( + )}$ \\
\hline Leistungspunktesysteme & Zugang, Anrechnung & $\mathbf{( - )}$ & $\mathbf{+}$ \\
\hline $\begin{array}{l}\text { Verfahren der Anerkennung und } \\
\text { Validierung von vorgängigem } \\
\text { Lernen }\end{array}$ & Zugang, Anrechnung & $\mathbf{( - )}$ & $\mathbf{( + )}$ \\
\hline $\begin{array}{l}\text { Individualisierte Beratungs- und } \\
\text { Unterstützungsangebote }\end{array}$ & Umgang mit Heterogenität & $\mathbf{( - )}$ & $\mathbf{( + )}$ \\
\hline $\begin{array}{l}\text { Flexibilisierung des Bildungsan- } \\
\text { gebots (z.B. Teilzeit) }\end{array}$ & Umgang mit Heterogenität & $\mathbf{( - )}$ & $\mathbf{+}$ \\
\hline $\begin{array}{l}\text { Berufspraktische Bildung im } \\
\text { Hochschulsystem }\end{array}$ & $\begin{array}{l}\text { Organisationale Verbin- } \\
\text { dung }\end{array}$ & $\mathbf{+}$ & $\mathbf{+}$ \\
\hline Qualifikationsrahmen & Zugang, Anrechnung & - & $\mathbf{+}$ \\
\hline
\end{tabular}

- $\quad$ keine Regelungen, die den europäischen Standards entsprechen

(-) keine Regelungen bis auf wenige nicht breit institutionalisierte Ausnahmen, geringe oder keine Bedeutung im Diskurs

$+\quad$ gesetzliche Regelungen, die den Standards entsprechen

$(+)$ regulative Veränderung in Richtung der Standards bzw. Sichtbarkeit im Diskurs

Zusammenfassend zeigt sich, dass es einen großen misfit zwischen deutschen Strukturen und europäischen Vorgaben gab, aber dass sich die institutionellen Strukturen auf Ebene des Verständnisses von Durchlässigkeit und der Argumentationen sowie auf Ebene der Standards, die größtenteils auch rechtlich festgehalten wurden, stark an die Vorgaben angeglichen haben. Folglich wäre anzunehmen, dass erstens durch den misfit großer Handlungsdruck bestand und zweitens Europäisierungsprozesse einen Einfluss auf die Entwicklungen in Deutschland genommen haben. 


\subsubsection{Die Rolle der Europäisierungsprozesse}

In der Analyse der Diskurse nach europäischen Bezügen und der Befragung der Expert*innen zeigte sich, dass die Europäisierungsprozesse eine starke Dynamik in die Aushandlungsprozesse um das Verhältnis von Berufs- und Hochschulbildung in Deutschland gebracht haben. Das nachfolgende Zitat aus einem Interview soll dies veranschaulichen:

„Wir haben einen neuen Drive bekommen - durch Europa. Ganz klar. Nationale Bildungsdauerbaustellen, die wir in Sachen Durchlässigkeit hatten, z.B. auch OutcomeOrientierung - sind durch Europa befördert worden. Dem konnte sich Deutschland dann nicht mehr entziehen in seinen jeweiligen Partikularinteressen, die sich hier abbilden in Sozialparteien: Arbeitgeber, Arbeitnehmer, die Schulseite, und, und und - ist ja bekannt. Haben wir einen Drive bekommen. Ich habe den Eindruck, dass Bologna etwas losgetreten hat, wo man heute sagen kann - frei nach Goethe: Den Geist, den sie gerufen haben, werden sie nicht mehr los." (Interview BIBB1)

Insbesondere die Frage der Anrechnung ist eng mit dem Bologna-Prozess verknüpft und durch diesen neu in die deutsche Diskurslandschaft aufgekommen (Bernhard 2017a). Insgesamt wurde der Bologna-Prozess als Motor für deutsche Durchlässigkeitsreformen beschrieben. Der Einfluss des Kopenhagen-Prozesses auf Durchlässigkeitsstrukturen wurde v.a. in der Entwicklung und Einführung des Deutschen Qualifikationsrahmens (DQR $)^{4}$ gesehen. Ihm wurde sowohl im Diskurs als auch in den Interviews eine Katalysatorrolle zuerkannt. $\mathrm{Zu}$ begründen ist die Katalysatorfunktion damit, dass der DQR als Klassifikationssystem gelten kann. Und da Klassifikationssysteme der Legitimation und Aufrechterhaltung sozialer Kategorisierungen und damit auch Ungleichheiten dienen (vgl. Tilly 1998) sind sie stark umkämpft. Dies wurde auch im Rahmen der Diskussion in Deutschland deutlich. So wurde versucht durch Kategorisierungen und Grenzziehungen bestehende Hierarchien im Bildungswesen aufrechtzuerhalten, indem zum Beispiel das Abitur ursprünglich auf eine höhere Kompetenzstufe eingeordnet werden sollte als drei- bis vierjährige Abschlüsse der Berufsausbildung. Gleichsam waren aber auch Akteur*innen aus Berufs- und Hochschulbildung gezwungen, sich auseinanderzusetzen mit Fragen zur Gleichwertigkeit von Berufs- und Hochschulbildung.

Die Expert*innen unterstrichen, dass das Thema Durchlässigkeit nicht mit den Bologna- und Kopenhagen-Prozessen aufs Tableau gekommen ist, aber durch diese unterstützt wurde. So haben die bildungspolitischen Akteure Europäisierungsprozesse genutzt, um überfällige Reformen umzusetzen (Interview BIBB1, BMBF). Dabei wurde auch verstärkt auf den bestehenden

4 Der DQR ist die nationale Umsetzung des Europäischen Qualifikationsrahmens und zielt darauf ab, die in Deutschland erworbenen Kompetenzen bildungsbereichsübergreifend in einem Rahmen darzustellen. 
misfit zwischen europäischen Erwartungen und nationalen Strukturen hingewiesen. Wichtig waren die europäischen Prozesse zudem, da sie durch die geforderten Standards Wege aufzeigten, wie nationale Durchlässigkeitsreformen umsetzbar sein könnten.

\subsection{Fazit: Europäische Prozesse als Gelegenheitsfenster}

Zusammenfassend lässt sich Folgendes festhalten: Erstens ist eine deutliche Entwicklung der institutionellen Durchlässigkeitsstrukturen in Richtung europäischer Vorgaben festzustellen. Zweitens haben Europäisierungsprozesse als Nährboden fungiert, um Ideen und politischen Lösungsansätze zu Durchlässigkeit zu fordern und zu fördern. Die Diskrepanz zwischen den europäischen Vorgaben und dem deutschen System in der regulativen Dimension wurde drittens nicht nur sichtbar, sondern auch aktiv von den Akteur*innen diskursiv genutzt, um mit Verweis auf die europäische Ebene eine starke Entwicklungsnotwendigkeit aufzuzeigen

Trotz dieser Entwicklung zu größerer Durchlässigkeit findet weiterhin eine Reproduktion der Trennung zwischen Berufs- und Hochschulbildung statt. Dies zeigt sich primär darin, dass die Frage von Durchlässigkeit umkämpft ist und sich ein strukturkritischer und ein -konservativer Diskurs gegenüberstehen. Dennoch können die europäischen Bildungsprozesse als Gelegenheitsfenster für deutsche Reformprozesse für Durchlässigkeit beschrieben werden.

\section{Literatur}

Auel, K. (2006): Europäisierung nationaler Politik. In: Bieling, H.-J. (Hrsg.): Theorien der europäischen Integration. Wiesbaden: VS Verlag, S. 293-318.

Baethge, M. (2006): Das deutsche Bildungs-Schisma: Welche Probleme ein vorindustrielles Bildungssystem in einer nachindustriellen Gesellschaft hat. In: SOFIMitteilungen No. 34. Soziologisches Forschungsinstitut an der Universität Göttingen, S. 13-27.

Baethge, M./Wolter, A. (2015): The German skill formation model in transition: from dual system of VET to higher education? In: Journal for Labour Market Research 48(2): $97-112$.

Banscherus, U./Bernhard, N./Graf, L. (2016): Durchlässigkeit als mehrdimensionale Aufgabe. Bedingungen für flexible Bildungsübergänge. Berlin: Friedrich-EbertStiftung.

Banscherus, U./Kamm, C./Otto, A. (2015): Information, Beratung und Unterstützung von nicht-traditionellen Studierenden. Angebote der Hochschulen und deren Bewertung durch die Zielgruppe. In: Hanft, A./Zawacki-Richter, O./Gierke, W. B. 
(Hrsg.): Herausforderung Heterogenität beim Übergang in die Hochschule. Münster u.a.: Waxmann, S. 81-96.

Bernhard, N: (2017a): Durch Europäisierung zu mehr Durchlässigkeit? Veränderungsdynamiken des Verhältnisses von Berufs- und Hochschulbildung in Deutschland und Frankreich. Opladen, Berlin, Toronto Budrich UniPress Ltd.

Bernhard, N. (2017b): Online-Anhang zum Buch: Durch Europäisierung zu mehr Durchlässigkeit? Veränderungsdynamiken des Verhältnisses von Berufs- und Hochschulbildung in Deutschland und Frankreich. https://shop.budrichacademic.de/wp-

content/uploads/2015/10/Bernhard_Onlineanhang.pdf?v=3a52f3c22ed6 [Zugriff: 16.8.2018].

Bernhard, N. (2018): Necessity or right? Europeanization and the question of permeability between vocational education and training and higher education in Germany and France. In: Carney, S./Schweisfurth, M. (Hrsg.): Equity in and through education: Changing contexts, consequences, and contestations. Rotterdam: Sense Publisher, S. 97-117.

BMBW (Bundesministerium für Bildung und Wissenschaft) (1992): Gleichwertigkeit beruflicher und allgemeiner Bildung. Rede von Fritz Schaumann. 1. BMBWFachtagung am 8.07.1992. Bonn: Bundesministerium für Bildung und Wissenschaft.

Börzel, T./Risse, T. (2003): Conceptualising the Domestic Impact of Europe. In: Featherstone, K./Radaelli, C.M. (Hrsg.): The Politics of Europeanisation. Oxford: Oxford University Press.

DIHK (Deutscher Industrie- und Handelskammertag) (2007): Wege der Beförderung von Anrechnung beruflicher Kompetenzen auf Hochschulstudiengänge. Statement von Dr. Knut Diekmann zur Abschlußtagung der ANKOM-Initiative. Bonn.

DIHT (Deutscher Industrie- und Handelstag) (1992). Gleichwertigkeit beruflicher und allgemeiner Bildung. Rede von Franz Schoser. Dokumentation der 1. BMBW Fachtagung am 8.07.1992. Bonn.

Euler, D./Severing, E. (2015). Durchlässigkeit zwischen beruflicher und akademischer Bildung. Daten, Fakten, offene Fragen. Gütersloh: Bertelsmann Stiftung.

Freitag, W. K./Hartmann, E. A./Loroff, C./Stamm-Riemer, I./Völk, D./Buhr, R. (Hrsg.) (2011): Gestaltungsfeld Anrechnung. Hochschulische und berufliche Bildung im Wandel. Münster: Waxmann.

Gläser, J./Laudel, G. (2006): Experteninterviews und qualitative Inhaltsanalyse: als Instrumente rekonstruierender Untersuchungen. Wiesbaden: VS Verlag für Sozialwissenschaften.

Graf, L. (2013): The Hybridization of Vocational Training and Higher Education in Austria, Germany and Switzerland. Opladen: Budrich UniPress.

HRK (Hochschulrektorenkonferenz) (2010). Stellungnahme „Europäischer Qualifikationsrahmen“. Deutscher Bundestag: A-Drs. 17(18)83c. Berlin.

Keller, R. (2006): Wissenssoziologische Diskursanalyse. In: Keller, R./Hirseland, A./ Schneider, W./Viehöver, W. (Hrsg.): Handbuch Sozialwissenschaftliche Diskursanalyse. Band 1: Theorien und Methoden Opladen: Leske+Budrich, S. 115146.

Keller, R. (2008a): Wissenssoziologische Diskursanalyse. Grundlegung eines Forschungsprogramms. Wiesbaden: VS-Verlag für Sozialwissenschaften. 
Keller, R. (2008b): Diskurse und Dispositive analysieren. Die wissenssoziologische Diskursanalyse als Beitrag zu einer wissensanalytischen Profilierung der Diskursforschung. Historical Social Research/Historische Sozialforschung, S. 73107.

KMK (Kultusministerkonferenz) (2002): Anrechnung von außerhalb des Hochschulwesens erworbenen Kenntnissen und Fähigkeiten auf ein Hochschulstudium. Beschluss der Kultusministerkonferenz vom 28.06.2002.

KMK (2009): Studium über berufliche Bildung. Wege und Berechtigungen. http://www.kmk.org/fileadmin/pdf/PresseUndAktuelles/2009/09-

09_Hochschulzugang_Berufliche_Bildung.pdf [Zugriff: 16.08.2018].

Meuser, M./Nagel, U. (2009): Experteninterview und der Wandel der Wissensproduktion. In: Bogner, A./Littig, B./Menz, W. (Hrsg.): Experteninterviews - Theorien, Methoden, Anwendungsfelder (3rd Edition). Wiesbaden: VS Verlag für Sozialwissenschaften, S. 35-60.

Mucke, K./Kupfer, F. (2011): Durchlässigkeit umsetzen für lebensbegleitendes Lernen - Schlussfolgerungen aus der Sicht der beruflichen Bildung. In: Freitag, W./ Hartmann, E. A./Loroff, C. et al. (Hrsg.): Gestaltungsfeld Anrechnung. Hochschulische und berufliche Bildung im Wandel. Münster: Waxmann, S. 221-238.

Powell, J. J. W./Bernhard, N./Graf, L. (2012): The Emerging European Model in Skill Formation: Comparing Higher Education and Vocational Training in the Bologna and Copenhagen Processes. In: Sociology of Education 85(3): 240-258.

Powell, J. J. W./Solga, H. (2011): Why are Participation Rates in Higher Education in Germany so Low? Institutional Barriers to Higher Education Expansion. In: Journal of Education and Work 24(1-2): 49-68.

Radaelli, C. M. (2000): Policy Transfer in the European Union: Institutional Isomorphism as a Source of Legitimacy. In: Governance: An International Journal of Policy and Administration 13(1): 25-43.

Ravinet, P. (2008): From Voluntary Participation to Monitored Coordination: why European countries feel increasingly bound by their commitment to the Bologna Process. In: European Journal of Education 43(3): 353-367.

Schmidt, V. A. (2008): Discursive Institutionalism: The Explanatory Power of Ideas and Discourse. In: Annual Review of Political Science 11: 303-326.

Scott, W. R. (2008): Institutions and Organizations: Ideas and Interests. (3. Auflage). Thousand Oaks: Sage Publications.

Strauss, A./Corbin, J. (1996): Grounded Theory: Grundlagen Qualitativer Sozialforschung. Weinheim: Beltz, Psychologie Verlags Union.

Waldow, F. (2009): Undeclared imports: silent borrowing in educational policymaking and research in Sweden. In: Comparative Education 45(4): 477-494. 


\title{
11 Learning Morality? Über die Notwendigkeit (der Vermittlung) von Normen und Werten im Kontext globaler Transformationen
}

\author{
Matthias Huber
}

\subsection{Eine Gesellschaft im Wandel}

Mit Blick auf die sich in den letzten Jahren abzeichnenden, sozialen und gesellschaftlichen Veränderungen in Europa, unter besonderer Berücksichtigung von Flucht und Migration, lässt sich eine grundlegend kritische oder zumindest aufmerksam gerichtete Haltung beobachten. Diese kollektive Fokussierung auf aktuelle, globale Transformationsprozesse spiegelt sich in unterschiedlichen Diskursen mit unterschiedlicher Reichweite wieder (vgl. Hoesch 2018): (1) In Medien und sozialen Netzwerken tritt plötzlich eine Vielzahl vermeintlich besorgter Bürger öffentlich in Erscheinung, diskutiert sozialpolitische Problemlagen und bezieht in einem stark ideologisch gefärbten Diskurs eindeutig klare Position. Die Bereitschaft sich als Privatperson zu aktuellen „Krisen“ zu äußern, respektive medial hochstilisierte Krisenherde öffentlich zu kommentieren, scheint mehr und mehr auf Akzeptanz und Wohlwollen zu stoßen, im Besonderen, wenn die entsprechenden Kommentare stark polarisieren (vgl. Lantermann 2018). Erweitert man die Perspektive (2) auf gesellschaftliche Teilbereiche, wie bspw. Wirtschaft, Bildung, Gesundheit oder Kultur, so wird auch hier deutlich, dass die sich inter- und transnational abzeichnenden Veränderungsprozesse tiefe Spuren im europäischen Selbstverständnis hinterlassen haben (vgl. Kleinschmidt 2015). Denn auch hier lassen sich in den letzten Jahren vermehrt klare politische Positionierungen mit ebenso klaren ideologischen Differenzen ausmachen. Und häufig scheint es dabei sogar gewünscht zu sein, sich einem bestimmten politischen Lager zuzuordnen bzw. zuordnen zu lassen. Beispiele hierfür wären die Folgen des Diskurses um Flucht und Migration auf die Vergabe von Kulturförderungen oder aber auf die Adaption des Wohnungsmarktes in mitteleuropäischen Ländern wie bspw. Österreich und Deutschland (vgl. hierzu bspw. Schirilla 2016). Erweitert man die Perspektive erneut wird die eben skizzierte Heterogenität gesellschaftspolitischer Anschauungen in einem 
globalen Ausmaß sichtbar: (3) Nationen und Nationenbündnisse treten vermehrt als gespalten respektive als sich konträr gegenüberstehend und ideologisch motiviert in Erscheinung, wenn es um die Frage nach der Bewältigung gegenwärtiger Herausforderungen - im Besonderen im Kontext von Flucht und Migration - geht. Waren es früher noch die sogenannten „Sende- und Aufnahmeländer" (vgl. Bauböck 2017), deren Interessen global thematisiert wurden und deren Repräsentanten sich zumindest performativ solidarisierten, so lassen sich heute sowohl in den sogenannten ,Zielländern“ als auch in den von Migration kaum betroffenen Staaten in Europa unterschiedliche Bündnisse mit klarer politischer Stoßrichtung ausmachen (vgl. Haller 2015).

Auffällig ist dabei, dass man innerhalb dieser drei Ebenen, unabhängig von der jeweiligen politischen Positionierung und Zugehörigkeit, in der Regel an die Werte, Normen und Konventionen von vermeintlich Gleichgesinnten plädiert, um sich ihrer zu vergewissern. Gleichzeitig werden diese Werte, Normen und Konventionen auch dazu instrumentalisiert, Andersdenkende oder vermeintlich Andersseiende auszugrenzen. Die Frage nach Norm- und Wertvorstellungen wird also zum Ausschluss- und/oder Inklusionskriterium, d.h. je nach Strategie als Ausgrenzungsmechanismus oder aber als Solidaritätsaufforderung genutzt.

Elisabeth Wehling (2016) hat diesen Zusammenhang im Kontext der äuBerst erfolgreichen und durchaus bemerkenswerten Framing-Strategien politischer Parteien und ihrer Protagonisten aufgezeigt: Meinungsbildung und politische Zugehörigkeiten unterliegen keiner bewusst-rationalen Entscheidung, sondern werden durch Sprache auf nicht-bewusster Ebene evoziert, die in weiterer Folge zu emotionalen Bewertungen führt, die wiederum Informationen im Verhältnis zu unseren Erfahrungen und unserem Wissen über die Welt einordnen (vgl. Wehling 2016, S. 17f. sowie S. 66f.). Doch es sind nicht nur rechtspopulistische Parteien und Politiker, wie bspw. Viktor Orbán und der ungarische Bürgerbund, Alexander Gauland und die Alternative für Deutschland oder Heinz Christian Strache und die Freiheitliche Partei Österreichs, die sich solcher Strategien erfolgreich bedienen. Auch die sogenannte „Willkommenskultur“, Europa-einende Ideen und jene Vertreter aus Politik, die sich für eine gemeinsame Lösung von Solidarität und Inklusion im Kontext von Flucht und Migration aussprechen, bedienen sich derselben Mechanismen wie ihre politischen Konterparts. Auch hier wird an jene Wertvorstellungen und Normen plädiert, die eine Zukunft des gemeinschaftlichen $\mathrm{Zu}-$ sammenlebens und des gegenseitigen Respekts erst ermöglichen. Wie erfolgreich Demokratien Werte instrumentalisieren und diese wiederum kollektives Denken und Handeln leiten (vgl. Wehling 2016, S. 191), zeigt sich aktuell an der politischen Situation Italiens, dessen neue Regierung sich im Juni 2018 aus der Protestbewegung Cinque Stelle und der rechtsradikalen Lega - zwei durchaus konträre und populistische Parteien - konstituierte. 
Zusammenfassend kann an dieser Stelle festgehalten werden, dass sowohl auf individueller als auch auf kollektiver Ebene die Frage nach der politischen (oder gesellschaftlichen) Positionierung in engen Zusammenhang mit den jeweiligen Wertvorstellungen, Normen und moralischen Haltungen steht und diese Wertmaßstäbe wiederrum selten auf bewusster bzw. rationaler Ebene angesprochen werden. Moral und Moralität werden somit zum impliziten Grundgerüst eines öffentlichen Diskurses.

\subsection{Global Education und Global Citizenship}

Eine weitere Perspektive, die die signifikante Bedeutung von Werten und Normen bzw. von Moral im Kontext globaler Transformationen verdeutlicht, findet sich in all jenen Programmen und Entwürfen, die sich mit den Bedingungen der Möglichkeit von Bildung für nachhaltige Entwicklung beschäftigen. Allen voran die Sustainable Development Goals (SDGs) der United Nations, siebzehn Ziele für nachhaltige Entwicklung, die am 01.01.2016 mit einer Laufzeit von 15 Jahren in Kraft traten. Unter den von allen UNMitgliedstaaten priorisierten Zielen findet sich auch das der Quality Education; das Ziel, eine inklusive, gerechte und hochwertige Bildung für alle Menschen zu gewährleisten und dabei die Möglichkeiten des lebenslangen Lernens zu fördern. Die UNESCO, also jene Sonderorganisation der United Nations, die sich u.a. um Wissenschaft und Bildung bemüht, und im Übrigen schon im Jahr 2000 das Programm Education for all mit einer 15jährigen Laufzeit zwischen 164 Staaten vereinbart hatte, koordiniert und steuert seit 2015 die Global Education 2030 Agenda. Die Idee globaler Bildung bzw. von Global Education inkludiert unterschiedliche pädagogische Zugänge, die jeweils spezifischen, sozialen Herausforderungen gerecht werden sollen. Mit Cabezudo et al. (2008) lassen sich folgende Bereiche innerhalb von Global Education unterscheiden: environmental education, peace education, human rights education, education for sustainable development and intercultural education (vgl. Cabezudo et al. 2008). Auch wenn die theoretische Differenzierung zwischen diesen Bereichen aus erziehungswissenschaftlicher Perspektive nicht sehr trennscharf ist, so lassen sich mit O'Loughlin und Wegimont (2008) dennoch spezifische, soziale Herausforderungen identifizieren, denen die einzelnen Bereiche von Quality Education gerecht werden sollen: Armut, Menschenrechte, Umweltschutz, Klimawandel, allgemeine Gleichberechtigung und internationale Kommunikation. Diese Herausforderungen wiederum stehen in engem Zusammenhang mit den zentralen Zielen von Global und Quality Education, wie sie mit Bezug auf die Prinzipien der Aufklärung und der Menschenrechtskonvention von den Vereinten Nationen und der UNESCO gemeinsam formuliert wurden: Toleranz, Gerechtigkeit, Frie- 
de, Anteilnahme, Inklusion, Solidarität, Brüderlichkeit und Gleichheit (vgl. O’Loughlin/Wegimont 2008). Das übergeordnete Ziel von „Global Quality Education " ist somit ein friedvolles und faires, gemeinschaftliches Zusammenleben fernab von Ausgrenzung und Diskriminierung.

Aufbauend auf das Konzept von Global und Quality Education, und von besonderer Bedeutung für die Frage nach der Vermittlung von Normen und Werten, entstand das von der UNESCO 2014 initiierte und mit einer Laufzeit von acht Jahren veranschlagte Programm der Global Citizenship Education. Es handelt sich dabei um einen Teilbereich der Sustainable Development Goals bzw. um das Ziel 4.7 des SDG 4 Quality Education (vgl. hierzu UNESCO 2018). Der Global Citizen respektive Global Citizenship versteht sich als ein theoretisches Identitätskonzept, losgelöst von der Zugehörigkeit zu Nationalstaaten oder anderen geographischen, ideologischen, religiösen oder politischen Gemeinschaften. Vielmehr geht es um ein Zugehörigkeitsgefühl und die Mitwirkung innerhalb einer globalen Gemeinschaft, die sich durch die Akzeptanz gegenüber kultureller, politischer und sexueller Heterogenität auszeichnet (vgl. Wintersteiner et al. 2014). Das Konzept von Global Citizenship strebt nach der Auflösung von destruktiven Ideologien und jeder Form von Radikalisierung. Das zentrale Ziel von Global Citizenship Education ist somit das Initiieren, Verbreiten und Sichern von demokratischen Werten sowie damit einhergehend die Sicherstellung und Wahrung einer globalen, friedvollen und pluralen Gesellschaft. Besonders im Kontext aktueller Transformationsprozesse unter besonderer Berücksichtigung von Flucht und Migration in Europa scheint die prinzipielle Idee von Global Citizenship Education als Ermöglichungshorizont von Inklusion, interkultureller Kommunikation und fairem gemeinschaftlichen Zusammenleben eine durchaus prospektive Perspektive zu eröffnen. Inwiefern ein solch stark normativ aufgeladenes, mehr appellativ anmutendes, als theoretisch fundiertes Identitätskonzept einer kritisch erziehungswissenschaftlichen Perspektive standhält, sei an dieser Stelle dahingestellt (vgl. hierzu bspw. Schattle 2008). Spannend hingegen ist die Tatsache, dass die zentralen Ziele von Global und Quality Education der SDGs, die gleichzeitig die Voraussetzung für die Idee des Global Citizen respektive der Global Citizenship darstellen, also Toleranz, Gerechtigkeit, Anteilnahme, Inklusion, Gleichheit etc., auf die Vermittlung spezifischer Normen, Wertvorstellungen und Konventionen abzielen. D.h. die übergeordnete Maxime einer Idee globaler Bildung - im Sinne einer emanzipierten, pluralen, aufgeschlossenen und gleichzeitig toleranten, gleichberechtigten und fairen Gesellschaft - liegt ebenso in der Vermittlung von Normen und Werten begründet.

Die Frage nach der Möglichkeit der Vermittlung von Normen und Werten bzw. von Learning Morality kann somit innerhalb aktueller gesellschaftlicher Veränderungsprozesse, ihrer öffentlichen Wahrnehmung und Diskussion sowie der Möglichkeit, jenen gestaltend zu begegnen, als ein zentrales Mo- 
ment verstanden werden. Trotz alledem findet die erziehungswissenschaftliche Auseinandersetzung damit nur sehr ausgewählt statt. Um die Frage, wie erziehungs- bzw. bildungswissenschaftliche Einsätze der Vermittlung von Normen und Werten gerecht werden können, zu problematisieren, muss zuvor geklärt werden, wie sich diese Norm- und Wertvorstellungen im Allgemeinen konstituieren.

\subsection{Entwicklung, Aufrechterhaltung und Durchsetzung von Normen und Werten}

Ein zentrales Problem im Kontext von Moralerziehung bzw. Learning Morality betrifft den Umstand, und diesbezüglich ist man sich disziplinübergreifend einig, dass sich Werte, Normen und Konventionen, wie auch die Ziele von „Global Quality Education“, intentional nicht vermitteln lassen. D.h. moralisches Handeln, Gerechtigkeit oder Toleranz entziehen sich der gerichteten Einflussnahme in pädagogischen Interaktionen (vgl. Oser 2008). Wenn man sich allerdings aus emotionstheoretischer Perspektive die Frage stellt, wie sich Wahrnehmungsprozesse konstituieren, wie sich Lernprozesse gestalten, wie nachhaltige Entscheidungsfindungsprozesse zu Stande kommen und daran anschließend, wie sich kollektive und individuelle Wertvorstellungen bilden und aufrechterhalten, eröffnet sich die Möglichkeit dem Problem der Vermittlung von Normen und Werten pädagogisch zu begegnen (vgl. Huber 2018). Der Begriff Learning Morality soll dies im Gegensatz zur Moralerziehung verdeutlichen: Lernen wird hier eben nicht als aktiv steuerbarer, bewusster Prozess der Wissensaneignung verstanden, sondern als eine nichtbeobachtbare Entität, deren Ziel es ist, die Tatsache zu erklären, das Erfahrung Verhalten beeinflusst bzw. Veränderung bewirkt (vgl. Huber 2017). Dieses epistemologische Grundproblem, dass in erziehungswissenschaftlichen Kontexten häufig ausgeklammert wird, ist im Hinblick auf die Frage nach den Bedingungen der Möglichkeit der Vermittlung von Normen und Werten konstitutiv, wie sich im Folgenden zeigen wird.

Emotionen werden im Hinblick auf die Bedeutung für individuelle und kollektive Normen und Wertvorstellungen unterschiedliche Funktionen zugesprochen. Zwei Perspektiven sind dabei, insbesondere aus erziehungswissenschaftlicher Perspektive und mit Blick auf die Frage nach den Voraussetzungen für die Gestaltung nachhaltiger gesellschaftlicher Entwicklungsprozesse, hervorzuheben:

(A) Zum einen die Regulations- und Steuerungsmechanismen der Moral: Grundeinstellungen bzw. Normen und Werte werden durch Emotionen aufrechterhalten, durchgesetzt und befolgt, im Besonderen im Hinblick auf allgemein geltende Vorschriften für Handlungsmuster. Bspw. ist es in sozialen 
Gruppen nicht notwendig explizit zu kommunizieren, was innerhalb der Gruppe akzeptiert oder sozial erwünscht ist. Die unmittelbare Sanktion der Gruppe auf ein tatsächliches oder antizipiertes Fehlverhalten eines Mitgliedes erfolgt, weil die betreffende Grenz- oder Regelverletzung automatisch und kollektiv als solche emotional bewertet wurde. Diese Steuerungsmechanismen gehen mit einer symbolisch-normativen Ordnung einher (vgl. von Scheve 2013), die Emil Durkheim schon 1912 im Kontext religiöser Gemeinschaften beschrieben hat. Diese symbolisch normative Ordnung gewährleistet wiederum die Entstehung von Kohäsion, Integration und Solidarität in Beziehungen und/oder sozialen Gruppen (vgl. von Scheve 2011). D.h. die emotionale Bewertung von Vorstellungsbildern und Erfahrungen der eigenen Lebens- und Lerngeschichte respektive emotionale Markierungen steuern die Spezifikation allgemeiner und individueller Wertvorstellungen.

(B) Zum anderen sind die Entstehungs- und Entwicklungsmechanismen von Moral hervorzuheben: Wertvorstellungen und Normen sind nicht nur kulturabhängig, also der jeweiligen Sozialisation geschuldet (vgl. Eisenberg 2000), sondern, und dies ist entscheidend, können sie nur über emotionale Haltungen in zwischenmenschlichen Interaktionen vermittelt und dementsprechend ausgebildet werden. D.h. Emotionen und emotionale Markierungen - in Form der Wahrnehmung und Spiegelung eigener und fremder Emotionen sowie der Reflexion dieses Zusammenspiels in Abhängigkeit der situativen Bedingungen - ermöglichen erst die Ausbildung und Internalisierung von Wertvorstellungen und Normen im Kontext der individuellen Entwicklung (vgl. hierzu Hopf/Nunner-Winkler 2007). Diese Mechanismen beginnen schon mit den ersten Interaktionen zwischen Mutter und Säugling, bspw. durch die Spiegelung von Basisemotionen im Kontext präverbaler Kommunikation (vgl. Engelen 2012) und sind Teil eines lebenslangen Lernprozesses. Dieser Zusammenhang von Emotion und Moralentwicklung wurde durch zahlreiche Untersuchungen im Kontext der theory of mind (vgl. Förstel 2005) oder aber der social cognitive neuroscience (vgl. Lieberman 2007) bestätigt.

Zusammenfassend kann daher konstatiert werden, dass Emotionen in doppelter Hinsicht für Normen und Werte bzw. für individuelle und kollektive Wertmaßstäbe konstitutiv sind: Zum einen garantieren sie, in Form emotionaler Markierungen, die Aufrechterhaltung und Durchsetzung derselben, zum anderen sind sie die Voraussetzung für ihre Entstehung und Verfestigung im Kontext der individuellen Entwicklung (vgl. Huber 2018).

Mit dem Wissen, dass Emotionen in doppelter Hinsicht für Normen und Werte konstitutiv sind, kann die zuvor schon angedeutete Frage, wie erziehungswissenschaftliche Bezugnahmen und pädagogische Einsätze der Vermittlung von Normen und Werten gerecht werden können, möglicherweise beantwortet werden. 


\subsection{Erziehung, Bildung und die Vermittlung von Moral}

Geht man also davon aus, dass Emotionen und emotionale Markierungen als Basis und Voraussetzung von Normen, Werten und Konventionen verstanden werden können und gleichzeitig moralische Maßstäbe steuern und daher moralisches Handeln ermöglichen, ist es notwendig zu fragen, welche pädagogischen Strategien sich hieraus ableiten lassen.

Roland Reichenbach und Bruce Maxwell (2007) versuchen diese Frage zu beantworten. Ihr theoretischer Ausgangspunkt ist die Annahme, dass Erziehung immer Moralerziehung und Moralerziehung immer eine Erziehung der Gefühle sei (vgl. Reichenbach/Maxwell 2007, S. 11). Das Problem in der Theorie der „Bildung und Erziehung von Emotion und Gefühl“, insbesondere im Kontext anthropologischer Überlegungen, ist die Voraussetzung von Autonomie und Selbstbestimmung bei gleichzeitigem Erhalt von bzw. Respekt gegenüber dem persönlichen Raum des Individuums. Diese ethische Begrenzung ist ein Ausdruck der nicht aufhebbaren Antinomie pädagogischen Handelns, die schon Immanuel Kant 1803 mit der Frage „Wie kultiviere ich die Freiheit bei dem Zwange?" im Rahmen seiner Pädagogikvorlesung zugespitzt formuliert hat (vgl. Kant 1983 [1803], S. 711). Gemeinsam mit dem Technologiedefizit der Erziehung, also dem Problem eines fehlenden Kausalzusammenhangs von Ursache und Wirkung, würden sich erziehungswissenschaftliche Strategien im Kontext ,der Bildung und Erziehung von Emotion und Gefühl“, verstanden als lineare Handlungsanleitungen oder kausale Gesetzmäßigkeiten pädagogischer Praxis schlichtweg selbst disqualifizieren. (Das pädagogische Paradoxon von Antinomie und Technologiedefizit lässt sich übrigens auch auf aktuelle Maßnahmen im Kontext der sogenannten „Integrationsarbeit" übertragen).

Um dieses grundlegende Problem zu überwinden, unterscheiden Reichenbach und Maxwell (2007) in Anlehnung an Anton Hüglis (1999) „Philosophie und Pädagogik" zwei theoretische Konzepte, die Autonomiepädagogiken und die Kontrollpädagogiken. Während die Strategien und Maßnahmen einer Kontrollpädagogik versuchen Verhalten durch Manipulation zu modifizieren, ohne auf das eigene Wollen und die eigne Einsicht Rücksicht zu nehmen, zielen die Strategien der Autonomiepädagogik darauf $a b$, die persönliche und moralische Autonomie des Individuums $\mathrm{zu}$ fördern (vgl. Hügli 1999). Somit ist nicht die Internalisierung von Normen, Werten und Konventionen das zentrale Ziel von Pädagogik, sondern moralische Autonomie, verstanden als die Fähigkeit sich selbst zu fragen, ob und inwiefern die eigenen Wünsche wünschenswert sind und ob es gut ist $\mathrm{zu}$ wollen, was man glaubt zu wollen. In diesem Sinne müssen die Strategien der Autonomiepädagogik verstanden werden als „Strategien der Aufforderung“, weil die Aufforderung - moralphilosophisch und emotionstheoretisch - der Idee von 
Autonomie und Selbstbestimmung gerecht wird: Man kann ihr nachkommen oder aber man ignoriert sie. Dabei lassen sich mit Reichenbach (2018) drei Strategien der Gefühlserziehung im Kontext der Moralentwicklung unterscheiden:

- die Imagination, als die Aufforderung sich eine Gefühlsreaktion vorzustellen (Expression),

- die Imitation, als die Aufforderung, einen Gefühlsausdruck zu ändern, d.h. an Qualität und/oder Intensität zu modulieren (Modulation), und

- die Neubewertung, als die Aufforderung die Situation und die Angemessenheit der Gefühlsreaktion neu zu überdenken (Re-Evaluation) (Reichenbach 2018, S. 23).

Auch wenn die Differenzierung zwischen den einzelnen Strategien der Gefühlserziehung nicht eindeutig und die Übergänge zwischen ihnen eher flieBend sind, veranschaulichen sie, dass die Vermittlung von Normen und Werten respektive Learning Morality als eine „Aufforderung zur Bildung der Gefühle" verstanden werden muss. Und dies bedeutet, dass Learning Morality nur unter emotionstheoretischen Gesichtspunkten realisierbar ist: Wir müssen lernen, eine Emotion oder einen emotionalen Zustand zu überdenken, uns von spezifischen emotionalen Bewertungen zu distanzieren oder aber Erfahrungen, Vorstellungsbilder und Repräsentationen gänzlich neu emotional zu bewerten und wir müssen ebenso lernen, uns in bestimmten Situationen mit bestimmten Emotionen auseinanderzusetzen oder aber jene gezielt zu imaginieren.

An dieser Stelle ließen sich eine Reihe von repräsentativen Praxisbeispielen anführen, wie bspw. spezielle Sensibilisierungsprogramme im Kontext der Jugendrisikoforschung, Förderprogramme zur moralischen Entscheidungsfindung oder aber Trainingsprogramme im Kontext des SozialEmotionalen-Lernens (SEL). Beispielhaft sei an dieser Stelle die Arbeit der in Europa kaum bekannten WWA (Word Without Anger) genannt. Die WWA implementierte in den letzten Jahren erfolgreich ein Sensibilisierungsprogramm zur emotionalen Kompetenz in Schulen in Nepal, Nordindien und Bangladesch, Regionen die zu den ärmsten und am wenigsten entwickelten in Asien zählen. Im Rahmen des sogenannten Emotion Literacy Trainings, dessen Wirksamkeit in mehreren Studien positiv evaluiert wurde (vgl. bspw. Regmi et al. 2009), wurden bereits über 5000 Schülerinnen und Schüler in den erwähnten Ländern graduiert. Der inklusive Zugang der WWA deckt sich zudem mit den zentralen Zielen von Global Education und Global Citizenship Education und kann als ein vorbildhaftes Beispiel angeführt werden, wie mit geringem finanziellen Aufwand über emotionale Sensibilisierung die Vermittlung von Normen und Werten unabhängig von nationaler, politischer oder religiöser Zugehörigkeit erfolgreich gelingen kann. 
So außergewöhnlich und bemerkenswert solche Programme auch sein mögen, so kommen sie dennoch lediglich einem verschwindend geringen Teil von Schülerinnen und Schülern zugute. Die Fokussierung auf die Vermittlung formalen Wissens und formaler Bildung ist nach wie vor ein globales Phänomen, auch wenn die Forderung nach sozial-emotionalen und adaptiven Metakompetenzen seit Jahren im Zentrum bildungstheoretischer und bildungspolitischer Interessen steht. Daher soll abschließend für eine grundlegende, metatheoretisch fundierte Auseinandersetzung mit der Notwendigkeit der Vermittlung von Normen und Werten im Kontext erziehungswissenschaftlicher Theoriebildung plädiert werden.

\subsection{Fazit}

Aktuell gilt es nach ganzheitlichen Lösungen zu suchen, welche der Komplexität globaler Transformationsprozesse gerecht werden. Der Erziehungswissenschaft muss dabei, im Besonderen im Hinblick auf die Idee von interkultureller und globaler Bildung sowie im Kontext der Bildung für nachhaltige Entwicklung, ein besonderer Stellenwert zugeschrieben werden. Denn Pädagogik gilt im Kontext von und in Abgrenzung zu einem Kultur- oder Gesellschaftsbegriff als Vermittlungsinstanz und Überbrückungshilfe von Differenzen; d.h. an der Stelle, an der Kultur und/oder Gesellschaft ihrer Vermittlungsleistung nicht mehr nachkommen kann, tritt die Pädagogik in Erscheinung (vgl. Huber 2013). Die Vermittlungsleistung ist der Pädagogik somit immanent, aber eben nicht nur in ihrer scheinbar primären Aufgabe bezüglich der Generationendifferenz und der sozialen Differenz:

„Vermittlung bezeichnet das gesellschaftliche Problem, das der Entwicklung des Pädagogischen zugrunde liegt und zu dessen Lösung sie beitragen soll, ja dessen Lösung von Ihr abhängen soll, und zwar die Vermittlung von gesellschaftlichen Teilbereichen, ebenso wie von Individuum und Gesellschaft.“ (Kade 1997, S. 35)

Die Vermittlung von Normen und Werten respektive Learning Morality ist also schon a priori Teil der pädagogischen Aufgabe und daher Teil des erziehungswissenschaftlichen Selbstverständnisses. Mit Blick auf aktuelle, gesellschaftspolitische Problemlagen verschärft sich die Notwendigkeit dieser Vermittlungsleistung. Wie eingangs skizziert, werden Werte und Normen immer öfter willentlich zweckentfremdet respektive für gesellschaftliche Ausschluss- und/oder Inklusionsstrategien instrumentalisiert. Dies betrifft den privaten Raum, gesellschaftliche Teilbereiche sowie Nationen und Nationenbündnisse und geht mit einem kollektiven Gefühl des Zerrissen-Seins und dem Bild einer gespaltenen Gesellschaft einher. Wie wichtig die Vermittlung von Normen und Werten für eine moderne und aufgeklärte Gesellschaft 
ist, zeigt sich darüber hinaus in den einzelnen Zielen für nachhaltige Entwicklung. Besonders das Konzept von Quality Education und die Idee von Global Citizenship Education verdeutlichen die enorme Bedeutung von Wertvorstellungen und der Vermittlung eines moralischen Maßstabes für die prinzipielle Möglichkeit einer toleranten, gleichberechtigten, ideologiefreien und fairen Gesellschaft.

Mit dem Wissen, dass Werte und Normen durch Emotionen entwickelt, aufrechterhalten, und durchgesetzt werden und somit Emotionen eine normativ symbolische Ordnung gewährleisten, eröffnet sich für die Erziehungswissenschaft und ihre Vertreterinnen und Vertreter die Möglichkeit hier gestaltend einzugreifen. Denn Wertvorstellungen werden nicht nur durch Erziehungs-, Bildungs- und Sozialisationsprozesse geformt, sondern Moral muss prinzipiell als eine Bildung von und durch Emotionen verstanden werden. Emotionen und emotionale Markierungen sind in diesem Verständnis eine notwendige Voraussetzung von individuellen und kollektiven Wertmaßstäben und somit eine Voraussetzung von Denken und Handeln.

Learning Morality versteht sich dementsprechend nicht als eine Handlungsanleitung oder Praxisempfehlung. Es wäre völlig abwegig zu glauben, anderen Menschen bestimmte Wertvorstellungen durch manipulative Erziehungsstrategien aufoktroyieren zu dürfen. Wie auch Inklusion eine Herausforderung an sich (selbst) darstellt bzw. eine inklusive Gesellschaft sich nur selbst ermöglichen kann, geht es auch bei der Idee von Learning Morality darum, gemeinsam moralische Perspektiven zu ermöglichen. Voraussetzung für diese Vermittlungsleistung ist allerdings, dass man sich von religiösen Wertmaßstäben verabschiedet, Ideologien und ideologische Momente als solche entlarvt und unterbindet sowie jegliche Form von Ausgrenzung und Diskriminierung, sei es aufgrund von Geschlecht, Herkunft oder sexueller Orientierung, verurteilt und ihr aktiv entgegenwirkt. Gleichzeitig, und dies wird meines Erachtens oft ausgeblendet, braucht es eine Diskursbereitschaft und Gesprächskultur, die von Offenheit, Wertschätzung und Empathie gekennzeichnet ist. Erst dann wird es möglich sein, ein kollektives moralisches Bewusstsein zu generieren, das der nächsten Generation inhärent ist.

\section{Literatur}

Bauböck, R. (2017): Perspektivische Verschiebungen. Migration und Mobilität im Zeitalter der Globalisierung. In: Altenburg, F./Faustmann, A./Pfeffer, T./Skrivanek, I. (Hrsg.): Migration und Globalisierung in Zeiten des Umbruchs. Hamburg: Edition Donau-Universität Krems, S. 29-36.

Cabezudo, A./Christidis, C./Carvalho da Silva, M./Demetriadou-Saltet, V./ Halbartschlager, F./Miha, G.-P. (2008): Global Education Guidelines. Concepts and 
Methodologies on Global Education for Educators and Policy Makers. Lissabon: North-South Centre of the Council of Europe.

Eisenberg, N. (2000): Emotion, Regulation, and Moral Development. In: Annual Review of Psychology 51: 665-697.

Engelen, E.-M. (2012): Emotionen als Lernprozesse. Eine Theorie zur Semantisierung von Emotionen als Voraussetzung für das Verstehen seiner selbst und anderer. In: Zeitschrift für Erziehungswissenschaft 15, Sonderheft 16: 41-52.

Förstl, H. (2007): Theory of Mind. Neurobiologie und Psychologie sozialen Verhaltens. Heidelberg: Springer Medizin Verlag.

Haller, M. (2015): Die drei Europas. Wie die Integration zu neuen Spaltungen in Europa führte und wie man diese durch abgestufte Integration überwinden könnte. In: Aschauer, W./Donat, E./Hoffmann, J. (Hrsg.): Solidaritätsbrüche in Europa. Konzeptuelle Überlegungen und empirische Befunde. Wiesbaden: Springer VS, S. 21-47.

Hoesch, K. (2018): Migration und Integration. Eine Einführung. Wiesbaden: Springer VS.

Hopf, C./Nunner-Winkler, G. (Hrsg.) (2007): Frühe Bindungen und moralische Entwicklung. Aktuelle Befunde zu psychischen und sozialen Bedingungen moralischer Eigenständigkeit. Weinheim: Juventa Verlag.

Huber, M. (2013): Die Bedeutung von Emotion für Entscheidung und Bewusstsein. Würzburg: Könighausen \& Neumeier.

Huber, M. (2017): Lernen und Emotion. In: Jugendhilfe 55(5): 450-457.

Huber, M. (2018): Emotionale Markierungen. Zum grundlegenden Verständnis von Emotionen für bildungswissenschaftliche Überlegungen. In: Huber, M./Krause, S. (Hrsg.): Bildung und Emotion. Wiesbaden: Springer VS, S. 91-112.

Hügli, A. (1999): Philosophie und Pädagogik. Darmstadt: Wissenschaftliche Buchgesellschaft.

Kade, J. (2001): Vermittelbar/nicht-vermittelbar: Vermitteln: Aneignen. Im Prozess der Systembildung des Pädagogischen. In: Lenzen, D./Luhmann, N. (Hrsg.): Bildung und Weiterbildung im Erziehungssystem. Lebenslauf und Humanontogenese als Medium und Form. Berlin: Suhrkamp, S. 31-70.

Kant, I. (1983 [1803]): Über Pädagogik. In: v. Weischedel, W. (Hrsg.): Kant, Immanuel: Werke in 10 Bänden, Band (10). Darmstadt: Wissenschaftliche Buchgesellschaft, S. 691-764.

Kleinschmidt, J. (2015): Europäische Raumsemantik. Überlegungen zu einempostgeopolitischen Selbstverständnis. In: Jureit, U./Tietze, N. (Hrsg.): Postsouveräne Territorialität. Die Europäische Union und ihr Raum. Hamburg: Hamburger Edition, S. 97-118.

Lantermann, E.-D. (2018): Bollwerk Zivilgesellschaft? Der Drang zum Extremen und Fanatismus in diesen unsicheren Zeiten. In: Organisationsberatung, Supervision, Coaching 25(2): 239-248.

Lieberman, M. D. (2007): Social Cognitive Neuroscience: A Review of Core Processes. In: Annual Review of Psychology 58: 259-289.

O’Loughlin, E./Wegimont, L. (2008): Quality in Global Education. An Overview of Evaluation Policy and Practice. Lissabon: Global Education Network Europa. 
Oser, F. (2008): Zur Psychologie der Moralerziehung. In: Schneider, W./Hasselhorn, M. (Hrsg.): Handbuch der pädagogischen Psychologie. Göttingen: Hogrefe, S. 256-258.

Regmi, M. P./Shakya, S./Basnet, D. M. (2009): Anger Cognition of Nepalese Adolescents. In: World Without Anger Journal 3-4(1): 1-4.

Reichenbach, R./Maxwell, B. (2007): Moralerziehung als Erziehung der Gefühle. In: Vierteljahrsschrift für wissenschaftliche Pädagogik 83(1): 11-25.

Reichenbach, R. (2018): Die Herzensbildung und die Erziehung der Gefühle. In: Huber, M./Krause, S. (Hrsg.): Bildung und Emotion. Wiesbaden: Springer VS, S. $17-40$.

Sassen, S. (2017): Migranten, Siedler, Flüchtlinge. Von der Massenauswanderung zur Festung Europa. Frankfurt am Main: Fischer.

Schattle, H. (2008): Education for global citizenship. Illustrations of ideological pluralism and adaptation. In: Journal of Political Ideologies 13(1): 73-94.

Schirilla, N. (2016): Migration und Flucht. Orientierungswissen für die Soziale Arbeit. Stuttgart: Kohlhammer.

UNESCO (2018): Global Citizenship Education. Bildung zu verantwortlichen und aktiven WeltbürgerInnen. https://www.unesco.at/bildung/global-citizenshipeducation/gced-im-unesco-kontext/ [Zugriff: 01.06.2018].

von Scheve, C. (2013): Emotion and social structure. The affective foundation of social order. New York: Routledge.

von Scheve, C. (2011). Die soziale Konstitution und Funktion von Emotion: Akteur, Gruppe, normative Ordnung. In: Zeitschrift für Erziehungswissenschaft 14(2): 207-222.

Wehling, E. (2016): Politisches Framing. Wie eine Nation sich Ihr Denken einredet und daraus Politik macht. Köln: Edition Medienpraxis.

Wintersteiner, W./Grobbauer, H./Diendorfer, G./Reitmair-Juárez, S. (2014): Global Citizenship Education. Politische Bildung für die Weltgesellschaft. Wien: Österreichische UNESCO-Kommission. 


\title{
12 Die ,gute Schule“ im Schulwahldiskurs von Eltern an einer hizmet-inspirierten Schule
}

\author{
Thomas Geier, Magnus Frank, Dorothea Schmidt
}

\subsection{Einleitung}

Das DFG-Projekt „Die Pädagogik der Gülen-Bewegung“1 rekonstruiert im Anschluss an eine Vorstudie (2012-2014) seit Oktober 2016 die Praxis religiöser Gesprächskreise (sohbetler) im Kontext der sog. Gülen-Bewegung ${ }^{2}$ sowie deren biographische Relevanz für die daran Teilnehmenden (Geier/Frank 2018a; Geier et al. 2018). Im Fokus des erziehungswissenschaftlichen Interesses stehen damit Angebot und Nutzung eines non-formalen, mehr oder minder religiösen, d.h. muslimischen Bildungsraums, sowie jene Prozesse,

1 https://www.zsb.uni-halle.de/forschungsprojekte/die_paedagogik_der_guelen-bewegun/ [Zugriff: 06.12.2018].

2 Inwiefern es sich bei der Gülen-Bewegung um ein global agierendes (Bildungs-)Netzwerk mit eigenlogischem Diskurs (Agai 2004), eine religiöse Gemeinde (cemaat) oder auch einen machtdurchdrungenen hierarchisch organisierten Geheimbund handelt, für den sie dominant nach dem Putschversuch in der Türkei im Jahr 2016 gehalten wird (Yavuz 2018), lässt sich vor dem Hintergrund unserer Forschungsanlage nicht so leicht beantworten, wie es vielleicht von außen den Anschein haben mag. Zwar verfügt das Projekt über einen inzwischen mehrjährig andauernden sowie sozial stabilen Feldkontakt, doch stehen im Zentrum unseres Erkenntnisinteresses vielmehr die Biographien von Nutzer*innen und Praktiken derjenigen Angebote, wie sie die Gülen-Bewegung unterbreitet. Dies erforschen wir hauptsächlich im Feld religiös motivierter außerschulischer Gesprächskreise (sohbetler). Zwar stehen diese nicht außerhalb der Organisation der Bewegung, doch lässt sich von den lokalen Praktiken der sohbetler nicht bruchlos auf den organisationalen Charakter der Bewegung insgesamt schließen. Auch wenn das Interesse an einer Beantwortung dieser Fragen nach dem spezifischen Charakter der Bewegung umso drängender geworden sein mag, müssen wir die uns methodisch gesteckten Grenzen, den organisationalen Charakter der Bewegung zu erforschen, akzeptieren. Umgekehrt wäre es hingegen fahrlässig, zum einen Aussagen über den uns zugänglichen Kontext hinaus zu verallgemeinern und zum anderen subsumtionslogisch, alle Nutzer*innen der Angebote gleichsam als hörige Anhänger*innen Fethulah Gülens aufzufassen. Es zeichnet sich vielmehr ab, dass die unterschiedlichen Nutzer*innen der Angebote immer auch ein je unterschiedliches subjektives Verständnis davon haben, worum es sich bei der Gülen-Bewegung überhaupt handelt. 
mittels derer die für die Bewegung konstitutive sozial-religiöse Botschaft hizmet (türk. Dienst) im Rahmen migrationsgesellschaftlicher Verhältnisse ${ }^{3}$ in die Lebenswelten der Akteur*innen, übersetzt wird (Geier/Frank 2019). Ihre subjektiven Weltsichten untersuchen wir im Kontext ihrer Biographien und Bildungskarrieren und sehen sie dabei sowohl als Adressat*innen als auch als Übersetzende der Botschaft an.

In diesem Beitrag wenden wir uns einem weiteren Bildungsbereich zu, welcher ebenfalls der Gülen-Bewegung zugerechnet wird. Es geht um 26 private Schulen, die sich bundesweit auf 13 Standorte verteilen. Sie sind in privater Trägerschaft von lokalen, nicht miteinander (etwa durch einen Dachverband) verbundenen Bildungsvereinen errichtet worden und arbeiten als staatlich anerkannte Ersatzschulen ${ }^{4}$. Den Websites der meisten Schulen lässt sich der explizite Hinweis entnehmen, dass sie im Sinne von hizmet gegründet worden sind. In organisatorischer Hinsicht sind die Schulen mit dem Bildungsnetzwerk der Bewegung über das sozial-religiöse Engagement ihrer Gründer*innen und die Spendenbereitschaft von Unterstützer*innen verbunden. Während die sohbetler eine Form des sozial-religiösen Engagements der cemaat in der ,private sphere“ (Şen 2007) zum Ausdruck bringen, sind die Schulen Teil der öffentlichen Sphäre. Vor allem dies lässt sie immer wieder zum Gegenstand kontroverser Auseinandersetzungen werden.

Empirische Forschungen zu den angesichts der Masse von Privatschulen in Deutschland insgesamt äußerst wenigen Schulen liegen jenseits von journalistischen Beschreibungen (Thies 2013) und Überblicks- (Akbaba/Strunck 2012) sowie Handbuchartikeln (Geier/Frank 2018b), die das Feld sondieren, bislang erst in Ansätzen vor (etwa Onur 2010; Mazukatov 2013). Trotzdem die Aktivitäten durch die Gründung von Nachhilfevereinen bereits in den 1990er Jahren im Bildungsbereich ihren Anfang nahmen, kann bis heute von einer fast ausschließlich unter den Gründer*innen erzählten, (sozial-)wissenschaftlich jedoch kaum registrierten Institutionalisierungsgeschichte gesprochen werden (vgl. Kusnezow 2017).

3 Unter Migrationsgesellschaft verstehen wir in Anlehnung an Paul Mecheril (2004, S. 133) eine gesellschaftliche Formation, die nicht nur durch die Dynamik verschiedenartiger nationalstaatliche Grenzen überscheitender Migrationen und durch die leiblich-soziale Anwesenheit Migrierender und Migrierter geprägt ist, sondern innerhalb derer Diskurse um Migration stattfinden, die mittels symbolischer Zuschreibungen sowie gesellschaftlicher Klassifizierungen und Kategorisierungen über soziale Zugehörigkeiten und deren Praktiken, sie zuzuweisen, entscheiden.

4 Ersatzschulen müssen in Deutschland zwei Bedingungen erfüllen: erstens dürfen sie hinter den öffentlichen Schulen ,in ihren Lehrzielen nicht zurückstehen“ und zweitens die „Sonderung der Schülerschaft gemäß den Besitzverhältnissen der Eltern“ nicht befördern. Das hat zur Folge, dass nur geringfügige Schulgelder erhoben werden dürfen und impliziert dafür die grundständige Finanzierung der Schulen durch staatliche Mittel (vgl. Kraul 2014). 
Vor diesem Hintergrund interessieren wir uns in explorativer Weise neben dem Hauptaugenmerk, das in unserem Projekt auf dem außerschulischen Bereich liegt, auch für die Schulen der Bewegung ${ }^{5}$, wie sie gegründet wurden, welche Bildungsangebote sie unterbreiten und wie sie von den unterschiedlichen Akteur*innen gedeutet und aufgegriffen werden. Im Folgenden sollen dafür Ergebnisse einer nicht repräsentativen qualitativen Interviewstudie mit Eltern von Schüler*innen an den Stuttgarter BiL-Schulen ${ }^{6}$ diskutiert werden. Die Interviews sind in einem Lehrforschungsprojekt mit Masterstudierenden unter der Leitung von Thomas Geier an der PH Karlsruhe erhoben und anschließend im Rahmen zweier nicht publizierter Masterarbeiten in einem ersten Zugriff unter verschiedenen Fragestellungen ausgewertet worden (Ramme-Karadağ 2017; Bittner 2017).

Für den hier vorliegenden Beitrag legen wir uns die Frage vor, wie die Eltern der Schüler*innen den Entscheidungsdiskurs um eine „gute Schule“ für ihr Kind bzw. ihre Kinder aushandeln und sich darin positionieren (Wrana 2015). In diesem Sinne diskutieren wir wiederum v.a. die Nutzungsseite des schulischen Bildungsangebotes und schließen damit ebenso an den erziehungswissenschaftlichen Diskurs zur elterlichen Schulwahl an (vgl. Krüger/Helsper 2014; Gruehn/Koinzer 2018). In diesen werden wir eingangs kurz einführen, anschließend in deskriptiver Weise Gemeinsamkeiten und Unterschiede zwischen den Interviews inhaltsanalytisch aufzeigen, um sie daraufhin zueinander in Beziehung zu setzen und auf diese Weise eine diskursanalytische Auswertung des Materials zu skizzieren. Wir enden mit einem kurzen Fazit.

\subsection{Der „Migrationshintergrund“ elterlicher Schulwahl}

Stephan Lessenich sieht in der jüngeren Geschichte des Sozialstaates das Konzept der allgemeinen Wohlfahrt in Form eines ,sorgende[n] Sozialstaat[s]" (de Swaan 1993) seit geraumer Zeit einem fundamentalen Wandel

5 Diese bezeichnen wir als ,hizmet-inspiriert“, um damit als gemeinsames Kennzeichen der Schulen das sozial-religiöse Engagement hervorzuheben, aus dem heraus sie gegründet wurden.

6 Die Stuttgarter BiL-Schulen wurden 2005 als staatlich anerkannte Ersatzschulen vom Trägerverein Bildungs- und Schulverein Baden-Württemberg e.V. gegründet. Sie setzen sich aus einer Grund- und Realschule sowie einem Gymnasium und Wirtschaftsgymnasium zusammen. Auf der Website der Schule wird ausgeführt, dass die Abkürzung BiL Bezug nimmt auf das 1997 gegründete Bildungs- und Informationszentrum in der Landhausstraße, „das sich zum Ziel gesetzt hat, insbesondere Kindern aus Migrantenfamilien zu bestmöglichen Abschlüssen zu verhelfen“ (https://www.bil-schulen.de/info-service/faq/) [Zugriff: 06.12.2018]. 
ausgesetzt, den er angesichts der „Krisenkonstellation des wohlfahrtsstaatlichen Kapitalismus" als „Neuerfindung des Sozialen“ beschrieben hat (Lessenich 2013, S. 16). Gegenüber aus seiner Sicht irreführenden Interpretationen, die einerseits von einem Abbau des Sozialstaates oder andererseits von dessen Neoliberalisierung sprächen, analysiert Lessenich, dass auch der Sozialstaat den „,neuen Geist des Kapitalismus“ (Boltanski/Chiapello 2003) als „Geist der ,Aktivierung"“ aufgenommen habe, in dem er einen ,teils proklamierte[n], teils praktizierte[n] Wandel zur aktivierenden (...) Sozialpolitik“ in Gang gesetzt habe: „Der ,aktivierende' Sozialstaat ist eine große institutionelle Bewegung zur Bewegung der Individuen“ (Lessenich 2013, S. 16f.).

Hiermit ist ein Wandel beschrieben, der auch im Bildungssystem nicht ohne Folgen geblieben ist. Auf der organisatorischen Ebene der formal qualifizierenden Bildungsinstitutionen werden Schulen zu vermehrter Autonomie und dazu aufgefordert, sich nunmehr als Akteure im Kontext eines New Public Management zu begreifen (Radtke 2009). An einem kundenorientierten Steuerungsmodel ausgerichtet können sie darüber hinaus zusätzlich zur staatlichen Finanzierung private Gelder erwirtschaften und über die Ausarbeitung eigenständiger Curricula und fachlicher Schwerpunkte sowie der Erstellung von Schulprogrammen distinkte Profile entwickeln. Ausgegebenes Ziel dieser Bildungspolitik ist ein Wettbewerb, der nicht nur die Qualität steigern, sondern auch noch soziale Ungleichheiten verringern soll, weil so Eltern die für ihr Kind passende Schule differenzierter wählen könnten. „Schulen wählen ihre Schüler, Eltern die Schulen“ (ebd., S. 633) ist die damit verbundene Formel. Frank-Olaf Radtke hat für diesen sogenannten freien Schulmarkt jedoch schon früh kritisch prognostiziert, dass er nur zwischen den räumlich und sozial mobilen Mittelschichtseltern (Radtke 2000) stattfinden und damit urbane und soziale Segregation im Schulsystem forcieren wird.

Die veränderte Situation eines quasi-Marktes ${ }^{7}$ schulischer Angebote im Bildungssystem führt in Folge auch zu ihrer erziehungswissenschaftlichen Beobachtung. Fokussiert werden Prozesse elterlicher Wahl privater und öffentlicher Bildungsangebote ebenso wie Aus- und Anwahlprozesse innerhalb der frühkindlichen Erziehung bis hin zur hochschulischen Bildung (vgl. Suter 2013; Breidenstein et al. 2014; Kloß 2016; Gruehn et al. 2018). Die Forschungen zu elterlichen Schulwahlprozessen liefern zentrale Ergebnisse, an die wir mit der Thematisierung der elterlichen Wahl hizmet-inspirierter Schu-

7 Schulische quasi-Märkte kennzeichnet mit Manfred Weiß erstens, dass trotzdem kein offizieller Markt besteht, der durch Angebot und Nachfrage reguliert wird, es dennoch Möglichkeiten der Anwahl unterschiedlicher Schulen gibt. Zweitens, dass die angewählten Institutionen bei Erfolg mit Gratifikationen bzw. mit Sanktionen bei Misserfolg rechnen können und drittens, dass eine Profilierung durch erhöhte Autonomie möglich ist (Weiß 2001). 
len anknüpfen können. Wie etwa Georg Breidenstein et al. in ihren Forschungen zur elterlichen Grundschulanwahl zeigen, wird die Zuschreibung „Schule mit hohem Migrantenanteil“ von Mittelschichtseltern ohne sog. Migrationshintergrund als Warnsignal für das Risiko interpretiert, den erwünschten Bildungserfolg der eigenen Kinder aufs Spiel zu setzen (Breidenstein et al. 2014). Im Mittelpunkt der Begründungsfiguren, solche Schulen zu meiden, stehen u.a. eine ,gute Mischung“ von Kindern mit und ohne sog. „Migrationshintergrund“ bzw. von Kindern mit „deutscher“ und „,nichtdeutscher Herkunftssprache“" (vgl. dazu auch Karakayalı/zur Nieden 2016) nicht garantieren zu können. Eine imaginierte Form von abgestimmter Heterogenität stellt hier die gewünschte Norm dar, andernfalls „kippe“ die Schule. Die von den Eltern aufgerufenen Differenzbegriffe können als sozial geteilte und akzeptierte „Bildungsmarker“ (Sackmann 2015) gelten, die im Schulwahldiskurs offenbar eine explizite Positionierung erlauben, ohne sich dem moralischen Vorwurf auszusetzen, bestimmte Bevölkerungsgruppen persönlich zu diskriminieren. ${ }^{8}$

Eltern mit sog. Migrationshintergrund liegen hingegen als selbst Wählende zumeist weniger im Fokus der Schulwahlforschung und deren Perspektiven kommen folglich auch weniger zur Sprache. Unsere ersten eigenen Interviews zeigen, dass selbstverständlich auch die als „Migranten“ etikettierten Eltern ebenfalls diskursiv aushandeln, was eine ,gute Schule“ für ihre Kinder sein könnte. Hiermit zeigt sich allerdings auch ein Bias der übrigen Schulwahlforschung. Er orientiert sich an den Differenzverhältnissen, die selbst bereits aus den bildungsungleichen deutschen Verhältnissen resultieren und reifiziert diese in den empirischen Ergebnissen, anstatt deren Genese zu erklären.

Auch die Gründungsgeschichten der Schulen, die mit ideellem Bezug zu hizmet und finanzieller Unterstützung des Netzwerkes ins Leben gerufen worden sind, verweisen auf eine Positionierung der Gründer*innen und ihr Positioniert-sein in den bundesdeutschen Migrationsverhältnissen. Die Schulgründungen lassen sich in Deutschland als Reaktion auf ethnisch co-

8 Augenscheinlich kommt dieser Form einer De-Thematisierung von Diskriminierung in diskriminierender Rede entgegen, dass es den Interviewten damit möglich ist, auf, objekti$v^{\text {', }}$ d.h. wissenschaftliche Sachverhalte zu verweisen, die von ihnen als wertneutral eingeschätzt werden. Wissenssoziologisch gesehen wird der statistisch ausgewiesene, Befund ethnisch codierter Bildungsbenachteiligung im Sinne einer Semantik kommunikativ in den Diskursen elterlicher Schulwahl aufgegriffen und zeitigt über die Schulwahl segregierende Effekte. Folgt man der Logik der kommunikativen Argumentation der Eltern, die wiederum ihre Entscheidungsgrundlage darstellt, dann wird aus einer hohen Konzentration von als bildungsbenachteiligt Markierten an Schulen bildungsbenachteiligende Schulen. Hierüber reproduzieren sich offenbar die schulischen Segregationsprozesse. 
dierte Bildungsungleichheiten verstehen. ${ }^{9}$ Dies jedoch in spezifischer Weise. Die Gründer*innen haben ein Wissen darüber, selbst zu derjenigen gesellschaftlichen Gruppe zu gehören, die von Bildungsbenachteiligungen und Diskriminierungsrisiken in besonderem Maße betroffen ist. Sie sind daher genauso, wie diejenigen, an die sich ihr schulisches Angebot richtet, Expert*innen für diejenigen Diskriminierungsverhältnisse, die sie unter entsprechenden Anpassungsdruck setzen. Das informelle Netzwerk der Bewegung stellt das für die Gründungen benötigte finanzielle Kapital bereit. Den weiteren Unterhalt der Schulen besorgen Spendengelder, die zusätzlich zur staatlichen Unterstützung benötigt werden. Die Erfahrungen im Auf- und Ausbau von Bildungsorganisationen im Sinne von hizmet in der Türkei und anderen Ländern weltweit bieten das bereits erprobte Know-How, selbst mit einer Gründungsinitiative tätig zu werden. „Wir sind keine Türkenschule“ heißt es daher vielsprechend und distinktiv auch in den FAQs der BiL-Schulen. Die Negation der Etikettierung lässt sich nicht nur als offensive Ablehnung gegenüber dem öffentlichen Vorwurf lesen, eine „ethnische Nische“ (BoosNünning 2015) im Bildungssystem zu bilden, sondern auch als Versuch, das Stigma der „Türkenschule“ als Verdikt verminderter Leistungsfähigkeit entschieden zurückzuweisen.

Der eingangs erwähnte Wandel zum aktivierenden Sozialstaat bietet den Akteur*innen von hizmet einen sozialpolitischen Rahmen in Deutschland, in dem sie sich verorten, um sich in der ihnen gewohnten Weise sozial-religiös $\mathrm{zu}$ engagieren. Der Gründungsgeist von hizmet trifft sich sozusagen mit dem sozialpolitischen „Geist der ,Aktivierung““ (ebd., S. 17).

9 Hierin liegt eine entscheidende Spezifik der Schulen für das deutsche Bildungssystem, die insbesondere auch im internationalen Vergleich mit anderen hizmet-inspirierten Schulanbietern deutlich wird. Die hiesigen Schulen sind bspw. keinesfalls mit den „Harmony Public Schools“" in den USA gleich zu setzen. Denn als dortige charter-schools stellen sie den größten privaten Anbieter dar, beschulen v.a. eine ländliche Klientel, die nicht aus türkischen Einwanderern besteht. Sie nutzen mit „harmony“ eine gemeinsame Marke (vgl. Hall 2015). Ähnliches trifft auch auf die sog. Feza-Schulen in Tanzania zu, denen als augesprochene Eliteschulen eine „active role in shaping the educational landscape“ (Dohrn 2014, S. 233) zukommt. Dabei richten sie sich an eine „religiously mixed clientele“ (ebd.: 233), was sich auch in der Schülerschaft widerspiegelt (vgl. ebd., S. 243). Wie in den USA lassen sich auch in Tanzania unter den Schüler*innen i.d.R. keine türkischen Einwanderer finden, derweil die Lehrer*innen jeweils überwiegend aus der Türkei über das Netzwerk der Bewegung kommen. 


\subsection{Die Anwahl der BiL-Schulen - Fünf Elterninterviews im Vergleich}

Bei den interviewten Eltern von Schüler*innen an den Stuttgarter BiLSchulen handelt es sich um: Frau Şengül, Herrn Keskin und seine Tochter Ayşe, Herrn Bulut, Herrn Spahic und Frau Bachmann. ${ }^{10}$ Die Auswahl der Interviewten erfolgte in Rücksprache mit dem damaligen Geschäftsführer der Schule. Bereits in den Vorgesprächen wurde deutlich, dass es unter den Eltern sowohl solche gibt, welche die Ideen von Fethullah Gülen teilen, als auch solche, die davon weniger überzeugt sind bzw. sich weniger dafür interessieren. Zur erst genannten Gruppe gehören Frau Şengül und Herr Bulut sowie auch Ayşe Keskin.

Frau Şengül lebt seit ihrem vierten Lebensjahr in Stuttgart. Sie arbeitet als Einzelhandelskauffrau und hat insgesamt vier Kinder, von denen drei die BiL-Schulen besucht haben bzw. noch besuchen. Sie selbst ist ehrenamtlich in einem hizmet-Verein tätig. Herr Bulut wohnt seit knapp 30 Jahren in Deutschland und hat drei Kinder, von denen vorerst zwei die BiLGrundschule und das BiL-Gymnasium besuchen. Als selbstständiger Informatiker ist er Inhaber dreier Firmen und einer der Initiatoren, der die Schulen mitgegründet hat. Ayşe Keskin besuchte wiederum selbst ab der neunten Klasse das BiL-Gymnasium, schloss dort ihr Abitur ab und arbeitet nun als Mediengestalterin.

Ihr Vater, Herr Keskin, ist in der Türkei geboren und in Deutschland aufgewachsen. Er hat vier Kinder. Neben Ayşe besucht auch ihre jüngere Schwester das BiL-Gymnasium. Zu den Personen ohne Verbindung zu hizmet zählt Herr Spahic, der aus dem ehemaligen Jugoslawien geflüchtet ist und im technischen Bereich arbeitet. Von seinen zwei Söhnen besuchen beide die BiL-Grundschule. Während seine Kinder nur wenige Minuten von der Schule entfernt wohnen, nimmt der einzige Sohn von Frau Bachmann eine Stunde Schulweg zum BiL-Gymnasium auf sich.

Die Interviews dauerten zwischen 20 Minuten und anderthalb Stunden und wurden entlang eines Leitfadens erhoben, der neben stärker geschlossenen Fragen allerdings auch ermöglichte, breite offene und narrative Passagen zu generieren. Der Interviewleitfaden behandelt die Themen einer persönlichen und familiären Vorstellung seitens der Interviewten, den Schulalltag

10 Die von uns codierte Namensgebung folgt bereits der empirischen Beobachtung, dass es sich sowohl um Eltern handelt, die als mit und ohne Migrationshintergrund adressierbar sind. Wir tun dies, um den je spezifischen Sinn der migrationsgesellschaftlichen Positioniertheit der Interviewten zur Sprache zu bringen. Auch wenn damit immer das Risiko einhergeht, den Gegenstand durch die eigene Forschung zu reifizieren (vgl. Diehm et al. 2013). 
und die Institution Schule sowie auch den damals aktuellen öffentlichen Diskurs über die BiL-Schulen. Wir werden im Folgenden Gemeinsamkeiten und Unterschiede entlang dieser Themen des Leitfadens skizzieren. In diesem Sinne handelt es sich zunächst um eine Deskription der thematischen Inhalte.

\subsubsection{Wege, auf denen man von der Schule erfahren hat}

Während der Interviews berichteten fast alle Eltern von Diskriminierungserfahrungen oder, wie Frau Bachmann es formulierte, von ,schwierigen Verhältnissen", mit denen sich ihre jeweiligen Kinder an den vorherigen Schulen konfrontiert sahen. In drei der fünf Fälle bestand dabei ein Zusammenhang mit der jeweiligen Grundschulempfehlung, welche damals für den weiteren Bildungsweg der Schüler*innen bindend war. ${ }^{11}$ So berichtet etwa Herr Keskin, dass er wie ,vor den Kopf gestoßen [war]“, als seine beiden Töchter „GANZ ${ }^{12}$ hauchdünn“ eine Haupt- statt Realschulempfehlung bzw. im Falle Ayşes eine Realschul- statt Gymnasialempfehlung erhielten. Beide Töchter besuchten sodann erst die vorgeschriebene Schule und wechselten jeweils nach einem Jahr - aufgrund einer revidierten Schulempfehlung - auf ein staatliches Gymnasium bzw. im Falle der jüngeren Tochter direkt auf die BiL-Realschule. Dem voraus ging die Empfehlung einer Freundin der Mutter und der Umstand, dass Ayşe auf dem staatlichen Gymnasium „UNGLÜCK-

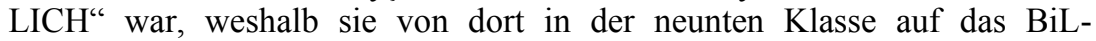
Gymnasium wechselte.

Als ein Mitbegründer der BiL-Schulen, erwies es sich als obsolet zu erfragen, wie Herr Bulut auf diese aufmerksam geworden ist. Interessant erscheint hier vielmehr, was ihn zur Mitgründung veranlasst haben könnte. Im Rahmen des Interviews berichtet er von seiner eigenen Schullaufbahn und dass er selbst aufgrund einer „Fehlentscheidung vom Lehrer“ zuerst die Hauptschule besuchen musste, jedoch später sein Abitur nachholte. Eine ähnliche Erfahrung machte auch seine Tochter, die trotz eines guten Notendurchschnitts nur die Empfehlung für eine Werkrealschule erhielt. Auf diesen „FATALEN Fehler“ reagierte Herr Bulut, indem er seine Tochter zu einem Test an der BiL-Schule veranlasste, der ihr schließlich die Befähigung zum Gymnasium bestätigte.

Während für Frau Șengül, nachdem sie in den hizmet-Nachhilfeinstituten von der Eröffnung der BiL-Schulen erfuhr, auch nur diese für ihre Kinder zur

11 Die verbindliche Grundschulempfehlung wurde in Baden-Württemberg 2012 abgeschafft. Seit dem Schuljahr 2018/19 wurde sie zur Vorlage an der weiterführenden Schule jedoch wieder eingeführt (vgl. Stuttgarter-Zeitung 06.04.2017, Serviceportal Baden-Württemberg 2018).

12 Hervorhebung von Großbuchstaben bei Betonung durch die Interviewten. 
Auswahl standen, besuchte der ältere Sohn von Herrn Spahic vorerst eine staatliche Grundschule. Seine Entscheidung für einen Grundschulwechsel erfolgte aufgrund von „technischen Gründen“, da die BiL-Grundschule in erster Linie einen ebenso kurzen Schulweg garantiert, die vorherige Schule nicht seine Erwartungen erfüllte und er schließlich „BESSERE Chancen“ für die Zukunft seiner Kinder an der BIL-Grundschule sah. Diese „besseren Chancen" macht er u.a. daran fest, dass - im Gegensatz zu den BiL-Schulen - an „staatlichen Schulen“ kein Interesse daran bestehe, ,aus dem Kind das BESTE :rauszufischen:", da es dort keine, auf das jeweilige Kind ausgerichtete, bedürfnisorientierte Förderung gebe. Wichtig ist für ihn in diesem $\mathrm{Zu}$ sammenhang gleichermaßen die schulinterne „Atmosphäre“, die er im Kontext der BiL-Schulen als „ENTSPANNT“ und an ,anderen öffentlichen Schulen“ als „,chaotisch“ bewertet.

Die schwierigen Verhältnisse auf dem vorherigen Gymnasium, die auch Auswirkungen auf das familiäre Zusammenleben hatten, veranlassten schließlich auch Frau Bachmann, nach alternativen Schulen für ihren Sohn zu suchen. Wichtig war ihr hierbei, dass es sich um eine Ganztagsschule handelte. Im Vergleich mit drei Gymnasien entschied sie sich aus Kostengründen sodann mit ihrem Sohn für seinen Schulwechsel auf das BiL-Gymnasium.

\subsubsection{Der Schulalltag aus Sicht der Eltern und einer ehemaligen Schülerin}

Da es sich bei den BiL-Schulen um Ganztagsschulen handelt, verweisen alle Eltern auf den regulären Schulbeginn um 8.00 Uhr und Schulschluss um 16.00 Uhr. Hierbei betont Ayşe, dass der typische Schulalltag auf der BiLSchule „wie auf einer ganz normalen Schule“ sei. So gibt es kleine Pausen und eine große Mittagspause, in welcher die Schüler*innen gemeinsam mit den Lehrer*innen zu Mittag essen. Diese würden dabei besonders darauf achten, dass in der Schule Deutsch gesprochen werde und, so Frau Şengül, dass bspw. auch gewisse „Tischregeln“ beim gemeinsamen Essen eingehalten werden. Herr Bulut berichtet außerdem davon, dass der reguläre Unterricht vor allem vor dem Mittagessen stattfinde, da danach der „Lerneifer“ der jüngeren Kinder abnehme, weshalb sich dann auch gezielt dem ,sozial- und emotionalen Aufbau“ der Schüler*innen zugewendet werde. Hierin verortet der Familienvater zugleich die Besonderheit der Schule, die sich nicht nur in einer „Rundumversorgung“, sondern vor allem in einem „,wirklichen MITEINANDER“" gründe. Dahingehend verweist er darauf, dass die Schule darum bemüht sei, die Schüler*innen, ihre Eltern und Lehrkräfte ,,in einen Einklang zu bringen“. So bspw. indem sie die Eltern durch regelmäßige Veranstaltungen, Seminare und Tagungen sowie Schulfeste aktiv in das Schulleben miteinbezieht. Dies bestätigen auch Herr Keskin und Herr Spahic, die 
außerdem auf Beispiele der persönlichen Anteilnahme in Krankheitsfällen durch die Lehrer*innen verweisen.

Neben den von Schüler*innen initiierten Lerngruppen und Arbeitsgemeinschaften nach der Schule, auf die Frau Bachmann und Ayşe eingehen, finden schulintern auch sog. fachspezifische VIP-Kurse am Wochenende statt, in denen Lehrer*innen besonders herausragende Schüler*innen zusätzlich fördern sowie fachlich schwächeren Schüler*innen Nachhilfeunterricht erteilen. Zudem werden auch in den Ferien Kurse, etwa zur Abiturvorbereitung, angeboten.

\subsubsection{Wünsche für die Zukunft der Kinder}

Die Wünsche der Eltern für den weiteren Bildungsweg ihrer Kinder zielen einstimmig auf deren Bildungserfolg sowie zum Teil auch auf deren weiteren beruflichen und persönlichen Werdegang. In diesem Sinne hofft Frau Bachmann, dass ihr Sohn ,die ZWEI JAHRE jetzt WEITER (-) so in der Schule klarkommt, sein Abitur macht, und dann sein Beruf sucht auf jedenfall“. Dieser Wunsch ist für Frau Şengül im Hinblick auf ihre zwei Töchter, die beide auf Lehramt studieren, und ihren Sohn, der einen Ausbildungsplatz im Büromanagement erhalten hat, schon weitestgehend in Erfüllung gegangen. Herr Bulut sieht im Bildungserfolg seiner Kinder wiederum mehr als nur die Möglichkeit eine, so Herr Keskin, „GUTE Ausbildung“ zu erhalten. Denn dieser erhofft sich, dass seine Kinder ,::gute: Menschen werden“ und „ihren Beitrag für die Gesellschaft leisten. Und das können die nur mit Bildung machen".

\subsubsection{Umgang mit öffentlichen Bildern: „, Türkenschule“ und „Gülen-Schule“}

Auf die Frage, wie das öffentliche Bild über die BiL-Schulen eingeschätzt wird, verweisen die Interviewten darauf, dass dieses vorurteilsbeladen, zwiespältig oder gar falsch sei, wobei die Vorurteile, gemäß Ayşe, Frau Bachmann und Herrn Bulut, auf ein unzureichendes Wissen zurückzuführen seien. Das von außen konstruierte Bild der Schulen unterscheidet sich nach Frau Bachmann je nach der ,Zeitung, welche man liest". Auf den Mediendiskurs bezieht sich auch Herr Spahic. Seiner Einschätzung nach entspricht das mediale Bild ,nicht der Wahrheit“. Frau Şengül sieht den Unterschied wiederum ethnisch codiert zwischen „Deutschen“ und „Türken“. Sie führt näher aus, dass erstere die Schule als „Türkenschule“ wahrnehmen würden, derweil das Bild „bei den Türken [...] geteilt" sei, was sie auf die ,politisch bedingten“ Umstände in der Türkei zurückführt. In diesem Zusammenhang verweist sie auch darauf, dass einige Eltern ihre Kinder von der Schule nahmen, weil 
diese dem Verdacht ausgesetzt war und ist, eine „GÜLEN-Schule“ zu sein, „mit der sie nichts zu tun haben [wollen]“.

Hiermit sind zugleich die zwei zentralen öffentlichen Bilder der BiLSchulen als „Türkenschule“ und „Gülen-Schule“ angesprochen. Dies führt zu der Frage, inwieweit sich die Eltern in ihrem Bekanntenkreis dafür rechtfertigen müssen, dass sie ihre Kinder auf eine Schule schicken, die häufig abfällig als „Türkenschule“ bezeichnet und als eine Schule mit hohem Anteil von Schüler*innen mit sog. Migrationshintergrund diskursiv ausgehandelt wird.

In diesem Kontext heben Frau Bachmann und Herr Bulut hervor, dass die Bezeichnung „Türkenschule“ nicht unbedingt „abfallend“ bzw. „abwertend“ sei, da diese auch von ,türkische[n] Bekannte[n]“ verwendet werde bzw. von einer öffentlichen Auseinandersetzung mit den BiL-Schulen zeuge. Den hohen Anteil von Schüler*innen mit sog. Migrationshintergrund bewerten dabei beide positiv. So sieht Frau Bachmann darin einen Vorteil für ihren Sohn, sich „mit vielen Kulturen“ auseinandersetzen zu können und auch Herr Bulut betont in diesem Zusammenhang: „Nur eine KLEINE WELT sind wir [...]. Es wär ${ }^{6}$ doch schade, wenn die Kinder von dieser Welt nichts mitbekommen“. Nichtsdestotrotz berichten aber beide Befragten davon, sich im „Bekanntenkreis“ bzw. vor „einigen Kollegen“ für die Schulwahl rechtfertigen zu müssen. Dies trifft auch auf Frau Şengül, Herrn Spahic und Ayşe zu, die Erlebnisse schildern, in denen ihre jeweiligen Kinder bzw. im Fall Ayşe sie selbst, mit Vorurteilen über die BiL-Schulen konfrontiert wurden.

Im Rahmen der Rechtfertigung steht gleichermaßen die religiöse Ausrichtung der Schule zur Diskussion, die alle Befragten, bis auf Frau Bachmann und Herr Bulut, vehement dementieren. Dass der Islam „NATÜRLICH [...] Teil dieser Schule“ ist, begründet Frau Bachmann damit, dass viele Schüler*innen Muslim*a sind und es einen Gebetsraum gibt. Jedoch weist sie wie alle anderen Befragten auch - darauf hin, dass es keinen Religionsunterricht, wohl aber ein Weihnachtsfest gibt. In Herrn Buluts Antwort auf die Frage, ob die Schule eine religiöse Ausrichtung habe, betont er den Verzicht auf religiöse Inhalte im Unterricht, sieht zugleich aber „Menschlichkeit“ als Teil von Religionen an, die durchaus in der Schule im Sinne eines ,wirklich[en] MITEINANDER[s]“" alltäglich gelebt und auch gelehrt werde.

\section{4 „Keine Türkenschule“ - Interpretation und Diskussion}

Die skizzierte inhaltsanalytische Auswertung der Interviews zeigt, dass für die Eltern ganz unterschiedlich gewichtete Gründe vorliegen, die BiLSchulen für den Schulbesuch ihres Kindes bzw. ihrer Kinder ausgewählt zu haben. Es geht etwa um die Lehrerschaft, deren Pädagogik, das interkulturelle und interreligiöse Schulleben, hizmet als internationale Marke des Bil- 
dungserfolges oder die Schul- und Lernatmosphäre sowie das als überdurchschnittlich hoch empfundene Engagement der Lehrkräfte. Die Attraktivität der BiL-Schulen lässt sich allerdings erst dann angemessen beschreiben, wenn das diskursive Zusammenspiel aus ethnisch codierten Bildungsungleichheiten, Diskriminierungen durch Zugehörigkeitslogiken, dem vorherrschenden Säkularismus (Asad 2017), der „Neuerfindung des Sozialen“ und der Gülen-Bewegung als „global player“ (Adick 2012, S. 90) internationaler Bildungsinstitutionen annähernd in den Blick genommen wird. In diesem Zusammenspiel zeigt sich dann auch erst die spezifisch nationalgesellschaftliche Institutionalisierung von hizmet angesichts der globalen Verbreitung der Bewegung. Dieser Zusammenhang kann hier allerdings nur angedeutet werden.

Den unterschiedlichen Perspektiven ist übergreifend gemein, dass die Eltern den Diskurs über die ,gute Schule“ führen und sie sich darin positionieren. Ihre Schulwahlentscheidungen werden auf der Grundlage diskursiven Wissens im Horizont informeller Schulrankings getroffen, die sich danach strukturieren, welches Wissen über die Schulen am durchsetzungsfähigsten ist (Bittner 2017; Krüger 2014). Dabei entscheiden die eigene Positioniertheit im Diskurs und ihr kreativer Umgang damit über die Möglichkeiten der Selbst-Positionierung und der Transformation diskursiver Wissensbestände.

Im Gespräch mit denjenigen Eltern, die im vorliegenden Falle nicht nur darum wissen, dass sie selbst als Migrant*innen im Sinne genealogischer Fremdheit adressiert, sondern im hegemonialen Bildungsdiskurs geradezu als Gruppe von Bildungsverlierer*innen etikettiert werden, zeichnet sich sodann die Attraktivität der gewählten Schule ab. Die BiL-Schulen lassen sich als Angebot für den Bedarf einer Elternschaft verstehen, die sich selbst in der Lage sieht, den schulischen Wettbewerb durch die Anwahl einer Privatschule für sich zu nutzen. Sie bildet damit wohl auch eine Avantgarde innerhalb einer Gruppe, die in der Schulwahlforschung bislang zu derjenigen gezählt wurde, für die es schwerer sei, an der freien Schulwahl adäquat teilzuhaben (vgl. Tomlinson 2011). Damit zeigt sich im Feld von privaten Schulen eine Klientelinnovation (vgl. Geier/Frank 2018b).

Die BiL-Schulen erscheinen in den Interviews daher auch nicht als reformpädagogische Einrichtungen in dem Sinne, dass sie die herkömmlichen Methoden und strukturellen Mechanismen des Schulsystems durch eine neue Pädagogik in Frage stellen. Vielmehr lässt sich das innovative Moment darin sehen, trotz der Beschulung größtenteils als deutsch-türkisch adressierbare Schüler*innen, alles dafür zu tun, nicht als „Türkenschule“ gelten zu können. Sie arbeiten dem eigenen Stigma entgegen, wodurch sie sich der Unterstützung der Eltern sicher sein können.

Eine aufstrebende „migrantische Mittelschicht“ (Treibel 2015) sucht in einem durch die Privatschulinitiativen von hizmet modifizierten schulischen Wettbewerb folglich auf dem Quasi-Markt von Bildungsinstitutionen entge- 
gen der im öffentlichen Bildungssystem für ihre Kinder befürchteten bildungsbenachteiligten Schulkarrieren nach alternativen Möglichkeiten. Die zwar diskursiv weiterhin als „Türkenschulen“ symbolisch etikettierten BiLSchulen können, wie dies die Interviews zeigen, für die Eltern als ,gute Schulen" gelten, weil sie das Versprechen eines Bildungserfolges für ihre Kinder verbürgen können. Während die Mehrheit der türkischen Muslim*a in Deutschland sich auch weiterhin ihrem bildungsstatistischen Schicksal ausgesetzt sieht, hat sich mit hizmet nicht nur ein religiös motivierter, sondern v.a. auch finanziell potenter Akteur entschieden, in das Schulsystem einzugreifen. Es ließe sich daher ebenso davon sprechen, dass hier eben eine Bevölkerungsgruppe aktiv wird, die weiß, was es bedeutet, im deutschen Bildungssystem als Migrant*in zu gelten und damit positioniert zu sein. Sie gründen daher Schulen und suchen diese auf, die zu leisten versprechen, was das übrige Bildungssystem nicht zu leisten im Stande ist.

Hizmet greift dazu auf seine Organisationsgeschichte zurück und sieht sich damit in der Lage, einen Bildungserfolg zu versichern. Denn ihr Engagement im Bildungsbereich kann als Expertise gelten, über die das Netzwerk in besonderem Maße verfügt. Dazu gehört nicht minder ein Habitus weltlichen unternehmerischen Erfolgs, der die finanzielle Kraft des Netzwerks (zumindest bis zum Putsch) ermöglicht hat. Auch die Akteure von hizmet subjektivieren sich überwiegend als ,unternehmerisches Selbst“ (Bröckling 2007). Im Kontext einer umfassenden Transformation des Sozialen folgen sie nicht nur einem religiösen Heilsversprechen, dessen Anzeichen sich im statistisch unerwarteten Bildungsaufstieg der eigenen Klientel ankündigen kann. Ebenso treffen sie auf einen neosozialen individualisierten Aufruf zur Sorge um sich selbst (Foucault 1989) und den bildungspolitischen Wunsch, dass Schulen sich profilieren. Dies wird von den Akteuren auch im unternehmerischen Sinne aufgegriffen, indem sie Schulen gründen.

Um über die Perspektiven von hizmet-nahen Eltern zu sprechen, lassen sich die Interviews mit Frau Şengül und Herrn Bulut heranziehen. Sie unterscheiden sich von den anderen Eltern bezüglich ihrer Auffassung zur religiösen Ausrichtung der Schule. Beide eint, dass hizmet als sozial-religiöse Botschaft verstanden wird, die sich zugleich in einer erfolgreichen Praxis bewähren muss. Die Schulen sind in ihrer Perspektive auch ein Aufführungsort der Güte und Wahrheit des religiösen Heilsversprechens. Die Sorge um sich kann somit als Ausdruck der Lebenspraxis von Muslim*a im deutschen Säkularismus $^{13}$ verstanden werden. In ihrem „Kampf um Anerkennung“ (Honneth

13 Christliche Schulen können auf Finanzen zurückgreifen, die ihnen der Staat über die Kirchensteuer eintreibt. Ein bekenntnisorientierter christlicher Religionsunterricht ist an den meisten Schulen im Westen Deutschlands die Regel. Und katholische Schulen stellen ihre religiöse Ethik als Profil werbend zur Schau. Zugleich gilt ein Kopftuchverbot für Lehrer*innen in einigen Bundesländern und das Angebot islamischen Religionsunterrichts ist 
1994) treffen sie auf einen Diskurs in Deutschland, in dem muslimische Lebensformen vor dem Hintergrund der geopolitischen Lage stets der zugehörigkeitslogisch gerahmten Bewährung ausgesetzt sind, noch nicht ausreichend säkularisiert, nicht modern oder gar antimodern zu sein.

In der Beurteilung der schulischen Initiativen ließe sich mit Frantz Fanon (1985) davon sprechen, dass sie den Ansprüchen eines „weißen“ und das heißt im vorliegenden Falle dem Blick eines hegemonialen ,wir" zu entsprechen suchen - gerade auch aus Motiven, unmarkiert zu sein. Die Akteure betrieben, dieser Logik zufolge, nicht nur eine aktive und sorgende, sondern ebenso eine bis ins Detail lupenreine „säkulare“ Außendarstellung, wie dies bereits eine bloß oberflächliche Sichtung der Schulhomepages nahelegt.

Die These einer erzwungenen affirmierten säkularen Maskierung erweist sich zugleich aber als hochproblematisch. Denn sie entwirft die Akteure von hizmet als reaktiv und tendenziell als handlungsohnmächtig sowie sie ihre erziehungswissenschaftlichen Beobachter*innen stattdessen in eine Position setzt, für die potentiellen muslimischen Sehnsüchte von hizmet besser als jene für sich selbst sprechen zu können. Mit einem substantiellen Religionsbegriff ließe sich daher ebenso die These vertreten, dass die Idee säkularer Bildung, keine Reaktion, sondern geradezu ein Ausdruck des religiösen Geistes von hizmet selbst ist (Weber 2013). Die Akteure von hizmet thematisierten den Islam im Kontext der Schulen deswegen nicht, weil für ihre Interpretation des Islam eine epistemische Trennung von weltlicher und religiöser Bildung originär entscheidend sei. Den Unterschied zu betonen wäre dann vielmehr für sie notwendig, um den eigenen religiösen Anspruch einlösen zu können, beide Sphären in ihrer Eigenlogik zur Geltung zu bringen (vgl. Geier/Frank 2019).

\subsection{Schluss}

Die Schulen von hizmet bewegen sich in einer paradoxen Situation. Einerseits zielen sie darauf ab, Chancengleichheit im Bildungssystem herzustellen. Andererseits treiben sie einen Differenzbildungsprozess weiter, den das öffentliche Bildungssystem erst hergestellt und in Gang gesetzt hat. Es wäre aus unserer Sicht daher ein Forschungsdesiderat, die Schulen von hizmet im Vergleich mit den sog. segregierten Schulen im Regelschulsystem zu untersuchen, um genauer $\mathrm{zu}$ verstehen, welche Wahlentscheidungen innerhalb

nach wie vor umkämpft. Für den Islam gelten auch juristisch andere Regeln trotz grundgesetzlich festgeschriebener Gleichheit des Religiösen. Dies festigt weiterhin seine gesellschaftliche Rolle als „Religion der Anderen“ (Mecheril/Thomas-Olalde 2011). 
diskriminierender Verhältnisse für die davon Betroffenen eigentlich bestehen. Dies sollte unbedingt vor dem Hintergrund von Diskursen zu Säkularismus und unter Berücksichtigung der Position als Inspizierte (Doughan/Tzuberi 2018) geschehen, deren Wirkmächtigkeit wohl eher zu- als abnimmt.

\section{Literatur}

Adick, C. (2012): Transnationale Bildungsorganisationen: Global Players in einer Global-Governance-Architektur? In: Tertium Comparationis 18(1): 82-107.

Agai, B. (2004): Zwischen Netzwerk und Diskurs. Das Bildungsnetzwerk um Fethullah Gülen (geb. 1938): Die flexible Umsetzung modernen islamischen Gedankenguts, Hamburg: EB-Verlag.

Akbaba, Y./Strunck, S. (2012): Deutsch-türkische Schulen in Deutschland: Ein kontroverser Diskurs. In: Ullrich, H./Strunk, S. (Hrsg.): Private Schulen in Deutschland. Entwicklungen - Profile - Kontroversen, Wiesbaden: Springer VS, S. 131140.

Asad, T. (2017): Ordnungen des Säkularen: Christentum, Islam, Moderne. Konstanz: University Press.

Bittner, J. (2017): „Die Türken in Deutschland sind faul“. Rekonstruktion diskursiven Wissens in Elterninterviews zur Schulwahl der BIL-Schulen in Stuttgart. Unv. Masterarbeit, Karlsruhe.

Boos-Nünning, U. (2015): Schulen bauen und Bildung ermöglichen - Bildungsziele der Hizmet-Bewegung. In: Stiftung Dialog und Bildung: Materialien zu Dialog und Bildung, S. 14-22.

Boltanski, L./Chiapello, È. (2003): Der neue Geist des Kapitalismus. Konstanz: UVK.

Breidenstein, G./Krüger, J. O./Roch, A. (2014): ,Aber Elite würde ich's vielleicht nicht nennen.' Zur Thematisierung von sozialer Segregation im elterlichen Diskurs zur Grundschulwahl. In: Zeitschrift für Erziehungswissenschaft 17(3): 165180.

Bröckling, U. (2007): Das unternehmerische Selbst: Soziologie einer Subjektivierungsform. Frankfurt a.M.: Suhrkamp.

De Swaan, A. (1993): Der sorgende Staat. Wohlfahrt, Gesundheit und Bildung in Europa und den USA der Neuzeit. Frankfurt a. M.: Campus.

Diehm, I./Kuhn, M./Machold, C. (2013): Ethnomethodologie und Ungleichheit? Methodologische Herausforderungen einer ethnographischen Differenzforschung. In: Budde, J. (Hrsg.): Unscharfe Einsätze: (Re-)Produktion von Heterogenität im schulischen Feld. Wiesbaden: Springer VS, S. 29-51.

Dohrn, K. (2014): Translocal Ethics: Hizmet Teachers and the Formation of Güleninspired Schools in Urban Tanzania. In: Sociology of Islam 1(3-4): 233-256.

Doughan, S./Tzuberi, H. (2018): Säkularismus als Praxis und Herrschaft: Zur Kategorisierung von Juden und Muslimen im Kontext säkularer Wissensproduktion. In: Amir-Moazami, S. (Hrsg.): Der inspizierte Muslim. Zur Politisierung der Islamforschung in Europa. Bielefeld: transcript, S. 269-308.

Fanon, F. (1985): Schwarze Haut, weiße Masken. Frankfurt a.M.: Suhrkamp. 
Foucault, M. (1989): Die Sorge um sich. Sexualität und Wahrheit (Bd. 3). Frankfurt a.M.: Suhrkamp.

Geier, T./Frank, M. (2018a): Die Bildungsinitiativen der Gülen-Bewegung in Deutschland. Sozialwissenschaftliche Perspektiven. In: Barz, H./Spenlen, K. (Hrsg.): Islam und Bildung. Auf dem Weg zur Selbstverständlichkeit. Wiesbaden: Springer VS, S. 53-87.

Geier, T./Frank, M. (2018b): Schulreform als Selbsthilfe. Deutsch-Türkische Schulen. In: Barz, H. (Hrsg.): Handbuch Bildungsreform und Reformpädagogik. Wiesbaden: Springer VS, S. 301-314.

Geier, T./Frank, M. (2019): Übersetzungspraktiken im Säkularismus - Zu Konstellationen religiöser und szientifischer Wissensordnungen in muslimischen Gesprächskreisen. In: Engel, N./Köngeter, S. (Hrsg.): Übersetzen - Pädagogische Grenzziehungen und -überschreitungen. Wiesbaden: Springer VS (i. Dr.).

Geier, T./Frank, M./Bittner, J./Keskinkılıç, S. (2018): Pedagogy of Hizmet in Germany - Non-formal Educational Practices and Biographical Views of its Participants. In: Ethnography and Education. https:/www.tandfonline.com/doi/full/10.1080/17457823.2018.1471611 [Zugriff: 06.12.2018].

Gruehn, S./Koinzer, T. (2018): Schulwahl - Akteure, Motive und Befunde zum Wandel großstädtischer Schul(angebots)landschaften. In: Zeitschrift für Pädagogik 64(5): 581-585.

Gruehn et al. (2018): „Welche Schule passt zu meinem Kind??“. Elterliche Schulwahlentscheidungen und die Frage der Passung im öffentlichen und privaten Grundschulwesen. In: Zeitschrift für Pädagogik 64(5): 612-634.

Hall, M. (2015): Killing Ed - Charter Schools, Corruption, and the Gülen Movement in America. Austin: Visual Truth Projects.

Honneth, A. (1994): Kampf um Anerkennung - Zur moralischen Grammatik sozialer Konflikte. Frankfurt: Suhrkamp.

Karakayal1, J./zur Nieden, B. (2016): Harte Tür. Schulische Segregation nach Herkunft in der postmigrantischen Gesellschaft. In: Geier, T./Zaborowski, K. U. (Hrsg.): Migration: Auflösungen und Grenzziehungen. Perspektiven einer erziehungswissenschaftlichen Migrationsforschung. Wiesbaden: VS Springer, S. 8197.

Kloß, A. (2016): Der Studienwahlprozess. Soziale und institutionelle Einflussfaktoren. Wiesbaden: Springer VS.

Kraul, M. (2014): Privatschulen in Deutschland. In: Bundeszentrale für politische Bildung. http://www.bpb.de/gesellschaft/bildung/zukunftbildung/191321/privatschulen? $\mathrm{p}=$ all [Zugriff: 06.12.2018].

Krüger, H.-H./Helsper, W. (Hrsg.): 2014: Elite und Exzellenz im Bildungssystem. Nationale und internationale Perspektiven (Sonderheft der Zeitschrift für Erziehungswissenschaft, H. 19). Wiesbaden: Springer VS.

Krüger, J. O. (2014): Vom Hörensagen. Die Bedeutung von Gerüchten im elterlichen Diskurs zur Grundschulwahl. In: Zeitschrift für Pädagogik 60(3): 390-408.

Kusnezow, L. (2017): Die Institutionalisierung sozial-religiösen Engagements - Eine Untersuchung am Beispiel der Gründungsgeschichte des TÜDESB-Vereins, unv. Masterarbeit, Halle-Wittenberg.

Lessenich, S. (2008): Die Neuerfindung des Sozialen. Der Sozialstaat im flexiblen Kapitalismus. Bielefeld: transcript. 
Liebscher, D./Fritzsche, H. (2010): Grundlagen der Antidiskriminierungspädagogik. In: Pates, R. et al. (Hrsg.): Antidiskriminierungspädagogik Konzepte und Methoden für die Bildungsarbeit mit Jugendlichen, Wiesbaden: VS-Verlag, S. 101-113.

Mazukatow, A. (2013): Ethnographie einer migrantischen Privatschule in Berlin. Leistungsideale und die Herstellung von Gemeinschaft am TüdesbPrivatgymnasium. Unv. Masterarbeit, Berlin.

Mecheril, P. (2004): Migrationspädagogik. Weinheim/Basel: Beltz Verlag.

Mecheril, P./Thomas-Olalde, O. (2011): Die Religion der Anderen. Anmerkungen zu Subjektivierungspraxen der Gegenwart. In: Allensbach, B. et al. (Hrsg.): Jugend, Migration und Religion. Interdisziplinäre Perspektiven, Zürich: Pano, S. 35-68.

Onur, K. D. (2010): Bildung und Migration. Die Selbstorganisation der Migranten als Reaktion auf die Bildungsbenachteiligung am Beispiel von weiterführenden Privatschulen. Dissertation an der Universität zu Köln.

Radtke, F.-O. (2000): Schulautonomie, Sozialstaat und Chancengleichheit. In: Radtke, F.-O./Weiß, M. (Hrsg.): Schulautonomie, Wohlfahrtsstaat und Chancengleichheit. Ein Studienbuch. Wiesbaden: VS Verlag, S. 13-32.

Radtke, F.-O. (2009): Ökonomisierung. In: Andresen, S. et al. (Hrsg.): Handwörterbuch Erziehungswissenschaft. Weinheim/ Basel: Beltz Verlag, S. 621-636.

Ramme-Karadağ, L. (2017): Eine Untersuchung der elterlichen Perspektive auf die Schulwahl der BIL-Schulen in Stuttgart. Unv. Masterarbeit, Karlsruhe.

Sackmann, R. (2015): Die Bedeutung institutioneller Auswahlprozesse für die Erzeugung von Bildungsungleichheit. In: Helsper, W./Krüger, H. H. (Hrsg.): Auswahl der Bildungsklientel. Zur Herstellung von Selektivität in ,exklusiven“ Bildungsinstitutionen. Wiesbaden: Springer VS, S. 31-67.

Şen, M. (2007): Background for Understanding the Gülen Community. In: WahlrabSahr, M./Tezcan, L. (Hrsg.): Konfliktfeld Islam in Europa. Baden-Baden: Nomos, S. 327-346.

Serviceportal Baden-Württemberg (2018): Übergang in weiterführende Schulen. https://www.service-bw.de/lebenslage/-

/sbw/bergang+in+weiterfuehrende+Schulen-5001333-lebenslage-0 [Zugriff: 06.12.2018].

Stuttgarter-Zeitung (06.04.2017): Grundschulempfehlung. Von 2018/19 sollen Eltern das Papier vorlegen. https:/www.stuttgarterzeitung.de/inhalt.grundschulempfehlung-von-2018-19-sollen-eltern-das-papiervorlegen.af54c725-8850-462c-a6fb-c44a24e3fdef.html [Zugriff: 06.12.2018].

Suter, P. (2013): Determinanten der Schulwahl: Elterliche Motive für oder gegen Privatschulen. Wiesbaden: Springer VS.

Thies, J. (2013): Wir sind Teil dieser Gesellschaft. Einblicke in die Bildungsinitiative der Gülen-Bewegung. Freiburg i.B.: Herder.

Tomlinson, S. (2011): Die globale Wirtschaft, Minderheiten und Bildung. In: Amos, S. et al. (Hrsg.): Öffentliche Erziehung revisited. Erziehung, Politik und Gesellschaft im Diskurs. Wiesbaden: VS Verlag, S. 175-194.

Treibel, A. (2015): Integriert Euch! Plädoyer für ein selbstbewusstes Einwanderungsland. Frankfurt a.M./New York: Campus Verlag.

Weber, M. (2013): Die protestantische Ethik und der Geist des Kapitalismus [1920]. Hrsg. und eingel. von Dirk Käsler. München: Beck.

Wrana, D. (2015): Zur Analyse von Positionierungen in diskursiven Praktiken. Methodologische Reflexionen anhand von zwei Studien. In: Fegter, S. et al. (Hrsg.): 
Erziehungswissenschaftliche Diskursforschung. Empirische Analysen zu Bildungs- und Erziehungsverhältnissen. Wiesbaden: Springer-VS, S. 123-141.

Yavuz, M. H. (2018): The Three Stages of the Gülen Movement. From Pietistic Weeping Movement to Power-Obsessed Structure. In: Yavuz, M. H./Balc1, B. (Hrsg.): Turkey July 15th Coup. What Happened and Why, Salt Lake City: The University of Utah Press, S. 20-45. 


\title{
13 Medien - Politik - Erziehungswissenschaft? Platzierung und De-Platzierung von Experten in globalen Wissensregimen
}

\author{
Sarah Schaufler
}

\subsection{Einleitung}

Spätestens mit PISA sind pädagogische Themen im Fokus öffentlichpolitischer Debatten und Expertisen allgegenwärtig. Dies hat, neben massiven Umstrukturierungen von Bildungssystemen, die gesellschaftliche Wahrnehmung von Wissenschaft verändert, denn Forschung wird zunehmend nach ihrer sozialen Funktion bewertet (Zapp/Powell 2016, S. 538). Im Zuge von Leistungsvergleichsstudien ist beobachtbar, wie sich die bildungspolitische und mediale Aufmerksamkeit auf den Vergleich bündelt (Parreira do Amaral et al. 2015). In aktuellen Debatten wird der Fokus auf zahlenbasierter Expertise in globalen Kontexte eingebettet, die gekennzeichnet sind durch Metrisierung (Mau 2017) und einem "metrological mood" (Power 2004, S. 766) in der Wissenschaft und einem „comparative turn“ (Martens 2007, S. 42) in der Erziehungswissenschaft. Das öffentliche Interesse hat Folgen auf disziplinäre Debatten: Die zunehmende Verwendung der Methode des Vergleichs in der deutschen Erziehungswissenschaft (vgl. Schröder 2016; Pilz 2011; Treptow 2010; Liegle 2010; Biewer/Luciak 2010) stellt das fachliche Profil der Teildisziplin international-vergleichende Erziehungswissenschaft in Frage (vgl. Waldow 2015).

Der Vergleich wird im Kontext von gestiegenen Erwartungen an ,verlässliche' Forschung attraktiv (vgl. Pettersson et al. 2016). Als wissensbasierte Steuerung, Objektivierung, Standardisierung politischer Entscheidungen (Landri 2015, S. 81) und einer ,governance by numbers' (Grek 2009), wird die Funktion sowie Rolle von Wissenschaft für gesellschaftliche Prozesse neu aufgerollt: Reliabel, objektiv und nützlich - so lässt sich das neue Anforderungsprofil an wissenschaftliche Expertisen zusammenfassen, dass sich als neue Wissensregime institutionalisiert (Normand 2016).

Die Anforderungen unterscheiden sich je nach wissenschaftlichen Bereichen (Normand 2010) und werden mitbestimmt durch heterogene Außenbeziehun- 
gen der Disziplinen mit Akteuren aus Wirtschaft und Politik (Weingart/Schwechheimer 2015, S. 48f.). Die Erziehungswissenschaft konkurriert besonderer ,auf segmentierten Märkten“ (ebd., S. 49) um Aufmerksamkeit: Sie teilt sich die Bearbeitung ihrer Gegenstände mit anderen Disziplinen und konkurriert während der Wissensproduktion und auf den Disseminationsmärkten (vgl. Rieger-Ladich 2007, S. 164).

Medien sind ein besonderer Markt: Sie treiben durch die Produktion und Präsentation von (Gegen-)Expertise die Multiplikation und Diversifizierung öffentlicher Arenen voran (Normand 2016, S. 49). Auf diesem Markt sind Wissenschaft und Erziehungswissenschaft im Speziellen nur ein möglicher Experte unter vielen. Vor diesem Hintergrund argumentiert der Text, dass es der Disziplin zunehmend schwer fällt sich zu platzieren. Vielmehr füllen Expert*innen anderer disziplinärer Provenienz öffentliche Bedarfe an wissenschaftlicher Expertise aus.

In einem ersten Schritt werden die veränderten Verhältnisse von Politik, Medien und Wissenschaft in den Blick genommen, um ihre Neu-Kalibrierung und die Entstehung neuer Grenzen nachzuzeichnen, an denen sich wiederrum neue Akteure, wie Expert*innen, anlagern. In einem zweiten Schritt wird die besondere Bedeutung von Medien als Mittler dieser Expertise zwischen Wissenschaft und Politik in den Blick genommen. Drittens wird die Position der Erziehungswissenschaft zwischen öffentlichem und disziplinärem Interesse skizziert und abschließend ihre Platzierung in medialen Diskussionen an einem empirischen Beispiel beschrieben.

\subsection{Veränderte Verhältnisse zwischen Wissenschaft und ihren Öffentlichkeiten}

Die veränderten Verhältnisse von Wissenschaft und ihren Kontexten lässt sich eingebettet in zwei gesellschaftliche Transformationsprozesse beschreiben, die im Zusammenhang mit Debatten um eine neue Wissensproduktion stehen (Gibbons et al. 1994). Zum einen rückt die Produktion und Verbreitung wissenschaftlichen Wissens in das Zentrum politischer, wirtschaftlicher und medialer Interessen (Verwissenschaftlichung, Beck/Bonß 1989; scientization, Drori/Meyer 2006). Zum anderen wird eine Ausdifferenzierung der Gesellschaft sowie einer Fragmentierung von Wissen mit Verweis auf die Wissensgesellschaft diskutiert (Stehr 1994). In der Folge wird eine Verschiebung der Kontexte von erziehungswissenschaftlicher Wissensproduktion entlang zweier sozialer Phänomene beobachtbar: Erstens institutionalisieren und stabilisieren sich andere, neue Wissensproduktionsregime als ,new epistemic governance“ (Normand 2016), und zweitens, eingebettet in diese Regime, bilden sich neue strukturelle Ausformungen sowie Akteure heraus, 
diskutiert als hybride Organisationen und (mediale) Experten (Schützeichel 2008).

\subsubsection{Wissensregime}

Wissensregime strukturieren die Bearbeitung von Forschungsgegenständen und Wissensformen. Sie repräsentieren dominante und stabile Wissensordnungen und definieren Deutungsmuster von gültigem Wissen entlang von Prinzipien, Normen, Regeln und Prozeduren (Wehling 2007, S. 704) - kurzum: sie bestimmen, welche Gegenstände von welchen Akteuren produziert und verbreitet werden dürfen und sollen (Schützeichel 2008, S. 68). In der Folge konstruieren sie Abgrenzungen und regulieren die Anerkennung von Wissensformen und -arten, Problemspezifika sowie hierarchische Ordnung (bspw. wissenschaftliches und nicht-wissenschaftliches Wissen) (ebd.). Als soziale Institution etablieren und realisieren sie diverse und konkurrierenden Deutungs- und Handlungsmuster für soziale Probleme und bestimmen, welches Wissen in einem spezifischen Kontext als legitim angesehen wird (Wehling 2007, S. 704). Diese theoretische Perspektive ermöglicht die Interessen der verschiedenen öffentlichen und politischen Akteure (hier: in medialen Diskussionen) zu beschreiben, denn Wissensregime regulieren ebenfalls die Kriterien anhand derer soziale Systeme Erwartungshorizonte ausbilden und strukturieren (hier: an Expert*innen) (ebd.).

Die neuen Wissensregime sind zum einen gekennzeichnet durch die wahrgenommene Pluralität und Konkurrenz ihrer Wissensformen - jenseits disziplinärer Linien (ebd.). Obwohl sich Wissensformen diversifizieren (wissenschaftliches Wissen, Alltagswissen, wirtschaftliche, politische sowie mediale Argumentationen) und neue Akteure hinzutreten (staatlichen, privaten und kommerziellen Einrichtungen), zeichnen sich gesellschaftliche Präfenzen in den Wissensformen ab: datenbasierte quantitative Analysen mit Anwendungsbezug, produziert in internationalen Kontexten, sollen die Basis für politische Entscheidungen bereitstellen (vgl. Zapp/Powell 2016, S. 552f). Zum anderen verlagern sich gesellschaftliche Bewertungskriterien in den Produktionsprozess von Wissenschaft hinein (Weingart 2015) und verändern ihn entlang von Effektivitätskriterien (Wehling 2007). Das hat Folgen für die soziale Funktion von Wissenschaft: Die Wissensregime betonen den 'exchange-value' von Wissen anstelle des 'use-value' durch peers (Lawn/Keiner 2006, S. 158) - die Qualität wissenschaftlicher Arbeit wird an ihrer Effektivität für praktische Anwendungen gemessen anstelle ihres Nutzens für die scientific community. 


\subsubsection{Globalisierung und Wissensregime}

Die veränderten Grenzziehungen zwischen Wissenschaft und Öffentlichkeit sind globale Phänomene. Die gesellschaftlichen Erwartungen an Wissenschaft sind nicht limitiert auf einzelne Disziplinen oder nationalstaatlich gerahmte Wissenschaftsstandorte, sondern werden im Zuge einer globalen veränderten Wissensproduktion, versammelt um die Leitchiffre, mode $2^{\text {c }}$ (Gibbons et al. 1994), beschrieben. Mode 2 bezeichnet ein neues Modell der Wissensproduktion: die bisherigen Monopole der traditionellen akademischen Wissensproduktion (mode 1) verändern sich durch die Beteiligung neuer Akteure und den Einbezug des Anwendungskontextes.

Die globalen Kontexte wirken auf die Produktion steuerungsrelevanten Wissens ein. In politischen Entscheidungsprozessen nimmt der Stellenwert von global agierenden Expert*innen zu (,global panopticism“ Lindgard et al. 2013). Supranationale Organisationen (OECD, etc.) treiben transnationale Disseminationsprozesse voran und haben eine entscheidende Rolle in der Verbreitung von zahlenbasierten Expertisen wie PISA inne (Martens 2007).

Wissensbasierte Steuerung wird zur Grundlage von Wissenspolitik in Form einer „new epistemic governance“ (Normand 2016). Obwohl die fehlende Kontextualisierung vieler indikatorengestützter Vergleiche ihre Interpretationen begrenzt (Nóvoa/Yariv-Mashal 2003), werden Daten in gesellschaftlichen Debatten oftmals mit einer unhinterfragten Selbstverständlichkeit verwendet (Grek 2009) und erzeugen neue Reliabilitäten entlang von „,infrastructures of accountability“ (Lindgard et al. 2013, S. 552). Vergleiche werden zu einer bildungspolitischen Strategie und zugleich zu einem Steuerungselement: als ,governance by comparison“ (Martens 2007) wird politischer Wettbewerb vorangetrieben (Grek 2009, S. 25) der einen ,new educational policy consensus" (Brown et al. 1997, S. 7f.) erzeugt.

\subsubsection{Expert*innen in Wissensregimen}

Expert*innen werden oft beschrieben als Spezialist*innen mit besonderen Kenntnissen und Fähigkeiten. Im Kontext der neuen Wissensregime bildet sich Expertise erst durch ihre gesellschaftliche Anerkennung aus und ihrer erwarteten Funktion für die Gesellschaft, nicht alleine durch ihr Wissen (Schützeichel 2008; Hitzler 1994). In der Folge erhalten Expert*innen die Deutungshoheit über Problemsituationen. Zugleich wissen sie um ihre „Inszenierungsleistungen“ (ebd., S. 27) und können Zuständigkeiten „sozial zu plausibilisieren" (ebd.).

Die Verwendung wissenschaftlicher Expertise für öffentliche Belange ist kein neues Phänomen. Jedoch steht die Rolle von Expert*innen innerhalb der entstehenden Wissensregime vor neuen Herausforderungen. Sie sollen zu- 
gleich Wissen produzieren und in gesellschaftliche Diskurse einbringen: "We produce it as producers of discourses, and we bring it into play as social actors" (Sirota et al. 2001, S. 569). Die neuen gesellschaftlich formulierten Erwartungen an Expertise zeigen sich auch in der evidence-based-policy. Anhand von datenbasierten Expertise sollen Evidenzen politische und wirtschaftlich antizipierte Lücken füllen, die von akademischen Akteuren hinterlassen wurden (Normand 2006, 11f.). Dabei handelt es sich oft um Datensammlungen von geringer Attraktivität für die erziehungswissenschaftliche Forschung, wie etwa Gardner/Gallagher (2007) für Nord-Irland zeigen: Ein Großteil der öffentlichen Auftragsforschung geht an Beratungsfirmen, da Universitäten sich kaum an den Ausschreibungen beteiligen.

\subsection{Medienvermittelte Expertise}

Medien spielen bei der Vermittlung von wissenschaftlicher Expertise eine besondere Rolle. Sie sind nicht nur die zentrale Vermittlungsinstanz zwischen verschiedenen gesellschaftlichen Systemen (Weingart/Schulz 2014), sondern eine Ressource für öffentliche Legitimation von Wissenschaft sowie gesellschaftlicher Bewertungs- und Inszenierungsmechanismen (Franzen/Rödder 2013).

Als Rezeptions- und Transformationskontext vermitteln Medien zwischen Wissenschaft und Politik. Die medial verhandelten Inhalte, Gegenstände und Diskussionslinien lassen Rückschlüsse $\mathrm{zu}$ auf politisch-gesellschaftliche Interessenslagen, Relevanzen und Legitimierungen (Peters et al. 2008). Zugleich konstruieren sie die neuen Rollen und Funktionen von Wissenschaft in Medialisierungsprozessen mit. Sie wirken durch ihre Beobachtung auf alle Bereiche ein, diese wiederrum orientieren sich zunehmend an ihrem Nachrichtenwert (Grande et al. 2013). Medien sind selbst ein Kontext der Wissensproduktion, denn sie übermitteln Informationen und bearbeiten diese nach ihren systemimmanenten Selektions- sowie Darstellungskriterien.

Medien, so könnte ihre Funktionsbeschreibung lauten, stehen nicht unbeteiligt in der ,Mitte', sondern betten sich in das Feld der „Kräftebeziehungen“ ein (Bourdieu 1998, S. 20) und weisen eine hohe ,Brechungsstärke' auf: sie bauen die Ansprüche von Gesellschaft und Wissenschaft (wie Themen \& Expert*innen) in ihre eigene Darstellungs- und Vermittlungslogik ein.

Entlang dieser Logik beeinflussen Medien politische Prozesse: (1) die politische Agenda anhand von Themen, (2) sowie Konstruktion sozialer Probleme und Lösungen und (3) ihre mediale Resonanz ist Indikator für politischen Erfolg und Relevanzzuschreibungen (Petersen et al. 2010).

Medien sind demnach Kommunikationsgefüge, die sich stabilisierend und destabilisierend auf die öffentliche Rolle von Expert*innen auswirken: Sie 
kreieren ein Kommunikationsforum, indem sie Themen und Expertisen platzieren. In der Folge entsteht ein Markt der öffentlichen, und konkurrierenden, Reputationszuweisung, deren Steuerung sich disziplinpolitischen Bestrebungen entzieht (Weingart 1998).

Auf diesem öffentlichen Markt richtet sich Wissenschaft zunehmend nach medialen Kriterien und bildet eine Doppelrolle heraus. Rae Goodells (1977) Konzept des „visible scientist“ beschreibt einen Typus Wissenschaftler*in "being known not only for scientific expertise but also for public involvement" (Bucchi 2010, S. 932). Ihre Rolle ist durch die ,öffentliche Visibiliät" nicht länger auf wissenschaftliche Kontexte limitiert, sondern auf gesellschaftliche Prozesse erweitert (Dunwoody 2008). In der Folge wird Wissen nicht nur entsprechend aufbereitet, sondern mit Deutungshoheiten aufgeladen, die Zuständigkeit in Abgrenzung zu anderen markieren (Hitzler 1994).

\subsection{Und die Erziehungswissenschaft?}

In diesem Markt der Inszenierungsleistungen ist die Erziehungswissenschaft eine unter vielen. In ihren Selbstbeschreibungen hat sich hierfür die Chiffre ,Modus der Klage“ etabliert. Ihr Verhältnis zur Öffentlichkeit ist angespannt, denn sie wird „genutzt und verachtet zugleich“ (Tenorth 2014, S. 139). Andere Disziplinen sind erfolgreicher, allen voran ihre zwei relevanten Bezugsdisziplinen Psychologie und Soziologie. Ihre Stellung als Experte platziert sich in der Lücke zwischen öffentlichen und disziplinären Interesse, mit Folgen für die soziale Funktion der Erziehungswissenschaft. Dies lässt sich anhand dreier Beobachtungen beschreiben.

(1) Obwohl in der Öffentlichkeit Expert*innen zu pädagogischen Themen auf ein reges Interesse stoßen, fokussiert sich die Erziehungswissenschaft auf Bereiche pädagogischer Praxis (Lüders et al. 1998), statt ihrer disziplinexternen Diskurse, wie etwa familiäre Erziehung (Wigger/Marotzki 2008). In der Konsequenz, so die Autoren, entstand eine Schieflage, welche das geringe $\mathrm{Maß}$ an Wertschätzung der Disziplin in der Öffentlichkeit wiederspiegelt, und wie ich ergänzen möchte, der Erziehungswissenschaft an der Öffentlichkeit.

(2) Die Erziehungswissenschaft spitzt die Diskrepanz weiter zu: Sie ist maßgeblich mitbeteiligt, dass soziale in pädagogische Probleme umcodiert werden und politische, ökonomische etc. Strategien zurücktreten (vgl. Proske 2002). Entlang von Pädagogisierungsprozessen inszeniert sich die Disziplin als Problemlöser - und dies kann zu ihrer öffentlichen De-Legitimation beitragen, wenn sie verspricht, was sie nicht zu halten vermag, möchte oder kann. 
(3) Vor diesem Hintergrund lässt sich ebenso das eingangs beschriebene Interesse zur Methode des Vergleichs deuten: in der Lücke zwischen disziplinären und öffentlichen Interesse. Erziehungswissenschaft, so die Annahme, gerät in der Entstehung neuer Wissensregime in den Hintergrund, da sie den Bedeutungsgewinn des zahlenbasierten Vergleichs unterschätzt und sich hier erst langsam positioniert hat. Cowen (2014) weist darauf hin, dass obwohl

„'we' now have a successful science of transfer - [it] ignores almost all of the complex thinking in the field of 'academic comparative education' of the last 100 years; and that it is likely to take another couple of hundred years before it can approximate to being a science of successful social and educational predictions." (ebd., S. 282)

Die Teildisziplin verfügt über eine ausgereifte Methodologie, hat sich aber im Fokus auf das ,wie' des Vergleiches gleichsam selbst bereinigt. Der Fokus auf spezifische Form der Forschung führte auch zu einer ,Überkompensation“ durch Leistungsvergleichsstudien (Zapp/Powell 2016, S. 552). In der Folge sieht sie sich mit de-kontextualisierten Formen des Vergleiches konfrontiert, welche maßgeblich durch politische Debatten und supranationale Organisationen formiert werden und weniger durch ihre Teildisziplin.

\subsection{Methodische Vorbemerkungen}

Die nachfolgenden Ergebnisse sind ein Ausschnitt eines laufenden Forschungsprojektes zum Verhältnis von Wissenschaft und Öffentlichkeit. Forschungsleitend ist die Frage, welche (erziehungs)wissenschaftlichen Experten in medialen Diskussionen zu pädagogischen Themen rezipiert werden. Für den vorliegenden Artikel wurde die Analyse ergänzt durch die Frage nach der Stellung des Vergleichs in medialen Diskussionen.

Im Zeitraum von 2000 bis 2012 wurden in Wochenzeitungen (Frankfurter Allgemeine Zeitung, DIE ZEIT, Spiegel) insgesamt 613 Artikel nach pädagogisch-thematischen Schwerpunkten in einem mehrstufigen qualitativen und quantitativen Verfahren verschlagwortet. In einem induktiven begriffsgeleitenden Verfahren wurden 225 Themen codiert und in einem zweiten Schritt auf die 5 häufigsten und 5 geringsten Themen reduziert. Innerhalb dieser Themen wurde die öffentliche Fremdwahrnehmung von Expertise u.a. entlang ihrer öffentlichen disziplinären Markierungen beschrieben. ${ }^{1}$ Jede$^{*} \mathrm{r}$ Expert*in wurde pro Artikel codiert, um die Häufigkeit über alle Artikel hinweg

1 Die vorgestellten Ergebnisse präsentieren lediglich einen Ausschnitt der Analyse. Innerhalb des Forschungsprojektes wurden u.a. die disziplinäre Selbstbeschreibung, organisationale Einbettung sowie Zitationsformen erhoben. 
$\mathrm{zu}$ analysieren. Auf diese Weise wird analysiert, welche Expert*innen für welche pädagogischen Themen rezipiert werden.

Im Folgenden werden die am häufigsten rezipierten pädagogischen Themen und Expert*innen vorgestellt und anschließend die Stellung des Vergleiches beschrieben.

\subsection{Ein empirisches Beispiel: Platzierung (erziehungs)wissenschaftlicher Expert*innen in medialen Debatten}

Das mediale Interesse an pädagogischen Themen bündelt sich auf bildungspolitisch-schulische und familiär-erzieherische Themen (siehe Tab. 1).

Tabelle 1: Anteil der häufigsten pädagogischen Themen, im Zeitraum von 2000 bis 2012 in den drei Wochenzeitungen, Mehrfachzuordnungen (eigene Darstellung)

\begin{tabular}{|l|l|l|}
\hline Häufigste Themen & Häufigkeit & Prozent \\
\hline Bildungspolitik: Schule & 131 & 20,79 \\
\hline Familiäre Erziehung & 131 & 20,79 \\
\hline Medien & 122 & 19,37 \\
\hline Profession: Lehrer & 117 & 18,57 \\
\hline Frühkindliche Erziehung & 112 & 17,77 \\
\hline Gesamt & $\mathbf{6 1 3}$ & $\mathbf{1 0 0}$ \\
\hline
\end{tabular}

Die Artikel fokussieren zum einen institutionell-schulpolitische Themen (Bildungspolitik: Schule) sowie ihr Personal (Profession: Lehrer) und zum anderen auf Handlungspraktiken für erzieherisch-praktische Fragen im familiären Kontext (familiäre Erziehung) und in der institutionalisierten Frühförderung (frühkindliche Erziehung). Zudem lassen sich Thematiken zu digitalen, analogen Bildungs- und Freizeitmedien (Medien) finden.

Die Themen bilden den Rahmen innerhalb derer Expertisen und Expert*innen positioniert werden und konzipieren öffentliche Deutungsmuster pädagogischer Bearbeitungsmodi. Die mediale Positionierung von Expert*innen visualisiert die Orientierung für öffentliche und politische Entscheidungsgrundlagen und präsentiert den Referenzrahmen öffentlicher Bewertung und Anerkennung - und die Erziehungswissenschaft wird in diesen Diskussionen hinter ihren Nachbardisziplinen platziert (siehe Tab. 2). 
Tabelle 2: Verteilung der Experten und Expertinnen in der Medienberichterstattung entsprechend ihrer genannten disziplinären Zugehörigkeit in den Artikeln dreier Wochenzeitungen, Zeitraum 2000-2012 (eigene Darstellung)

\begin{tabular}{|c|c|c|c|}
\hline \multicolumn{2}{|l|}{ Disziplinen } & Häufigkeit & Prozent \\
\hline \multicolumn{2}{|c|}{ Erziehungswissenschaft/ Pädagogik } & 165 & 15,29 \\
\hline \multirow[t]{3}{*}{ Überschneidung } & & 102 & 9,45 \\
\hline & Bildungsforschung & 43 & \\
\hline & Didaktik & 13 & \\
\hline \multirow[t]{6}{*}{ Nachbardisziplinen } & & 290 & 26,87 \\
\hline & davon Psychologie & 92 & \\
\hline & $\begin{array}{l}\text { davon Sozialwissenschaf- } \\
\text { ten/Soziologie }\end{array}$ & 40 & \\
\hline & davon Medizin & 23 & \\
\hline & davon Neurowissenschaft & 28 & \\
\hline & sonstige & 107 & \\
\hline \multicolumn{2}{|l|}{ Zwischensumme } & 557 & \\
\hline \multicolumn{2}{|l|}{ keine genannt } & 522 & 48,38 \\
\hline \multicolumn{2}{|l|}{ Gesamt } & 1079 & 100 \\
\hline
\end{tabular}

Die Erziehungswissenschaft wird zwar häufig rezipiert (165/15,29\%), unterliegt jedoch in der Gesamtschau ihren Nachbardisziplinen (290/26,87\%) sowie Überschneidungsbereichen $(102 / 9,45 \%)$. Obwohl überwiegend Themen pädagogische Praxis verhandelt werden, hat die Erziehungswissenschaft geringe mediale Attraktivität.

Die disziplinäre Bezeichnung richtet sich nach der öffentlichen Fremdwahrnehmung, sprich, nach der begrifflichen Nennung in den Artikeln. So wurden zur ,Erziehungswissenschaft/ Pädagogik' die Nennung der Disziplin sowie ihre Teilbereiche (Pädagogik der Kindheit, Medienpädagogik, etc.) zugeordnet. $\mathrm{Zu}$ den Überschneidungsbereichen zählen hybride Bezeichnungen, die nicht in klassische disziplinäre Ordnungssysteme passen und/ oder aufgrund institutioneller Ausdifferenzierungen keine eindeutige Zuordnung zulassen (etwa Bildungsforschung, Didaktik und Forschungsrichtungen, Kleinkind- und Familienforschung, etc.; vgl. Aljets 2015).

Mit über 70\% aller Artikel sind Vergleiche fester Bestandteil in den Artikeln. 
Tabelle 3: Verteilung der methodischen Zugriffe in den Artikeln (eigene Darstellung)

\begin{tabular}{|c|c|c|}
\hline & Häufigkeit & Prozent \\
\hline vergleich & 285 & 72,70 \\
\hline Leistungsvergleichsstudie & 99 & \\
\hline davon PISA & 56 & \\
\hline davon weitere (TIMSS, etc.) & 43 & \\
\hline historisch & 107 & 27,30 \\
\hline Gesamt & 392 & \\
\hline
\end{tabular}

Das mediale Interesse ist nicht auf Leistungsvergleichsstudien begrenzt. Vielmehr dominieren Länderberichte, welche u.a. Erziehungsmethoden, Schulsysteme, Wertvorstellungen, mit deutschen Diskussionen in Beziehung setzen und die Erfahrungen ,Anderer' im Narrativ erzählen.

\subsection{Conclusio}

Der vorliegende Beitrag betrachtete das Verhältnis von Öffentlichkeit und Wissenschaft anhand der medialen Platzierung von Expert*innen. Vor dem Hintergrund gesellschaftlicher Transformationsprozessen lässt sich die Entstehung neuer Wissensregime beobachten, die bestimmte Arten von Expertise (zahlenbasierte Vergleiche) von bestimmten Expert*innen (Wissenschaft) bevorzugen. Die Erziehungswissenschaft ist in den Debatten nur ein Experte unter vielen.

Am Ende bleibt die Frage, was aus dem Disziplinvergleich für die erziehungswissenschaftliche Wissensproduktion folgt. Was, so lautet ein naheliegender Einwand, nützt es zu wissen, dass Disziplinen unterschiedlich medial positioniert werden, außer einen empirischen Beleg für den etablierten ,Modus der Klage' zu erhalten? Durch den vorliegenden Beitrag kann diese Frage nicht gelöst werden, jedoch nähert er sich der öffentlichen Funktionsbestimmung von Erziehungswissenschaft. Die Platzierung am medialen Markt ist, so könnte eine Schlussfolgerung lauten, eine Frage von Popularisierung von Wissen und Wissenschaftskommunikation. Die Konstitution von Expertise kann so als mediale Inszinierungsleistung gedeutet werden - oder im Fall der Erziehungswissenschaft: als fehlende Inszinierungsleistung.

Die Antwort scheint zu kurzgegriffen aufgrund der beschriebenen Schieflage von Distanz und Pädagogisierung der Erziehungswissenschaft zu ihrer Öffentlichkeit. 
Mit Blick auf die beschriebenen globalen Wissensregime bettet sich die Frage breiter ein: in die Prozesse einer möglichen Auflösung disziplinärer Produktionskontexte sowie der Verschiebung der Wissensproduktion von lokalen/nationalen Formen zu supranationalen Verbünden. Die Erziehungswissenschaft scheint besonders von disziplinären Verflüssigungen betroffen zu sein, da sie sich ihren Gegenstand mit anderen Disziplinen teilt. Dies kann durch interdisziplinäre Forschung noch weiter verstärkt werden. Diese Überlegungen führen $\mathrm{zu}$ einer grundsätzlichen Unterscheidung zwischen Forschung (Themen) auf der einen und Forschungskommunikation und -institutionalisierung (disziplinären Linien) auf der anderen Seite. Anstelle einer Differenzierung innerhalb von Forschung (Grundlagen- und Anwendungsforschung), die oftmals auch als wissenschaftliche Legitimierungsstrategie dient (Normand 2016), kann solch eine Unterscheidung komplementär gedacht werden (vgl. Schimank 1995). Sie können zwei Ebenen im Kontext der Organisation Wissenschaft darstellen, die sich gegenseitig bedingen und nicht ausschließen.

Auch wenn sich die Frage nach disziplinären Linien durch diese Verschiebung vorerst löst, öffnet es zugleich für Erziehungswissenschaft den Blick für die Funktion ihrer Grenzziehungen (Modus der Klage) bei gleichzeitiger Entgrenzung (Pädagogisierung): als eine disziplinäre Selbstbegrenzung bei einer gleichzeitigen thematischen Entgrenzung.

\section{Literatur}

Aljets, E. (2015): Der Aufstieg der Empirischen Bildungsforschung. Ein Beitrag zur institutionalistischen Wissenschaftssoziologie. Wiesbaden: SpringerVS.

Brown, P./Halsey, A. H./Lauder, H./Stuart Wells, A. (1997): The transformation of education and society: An introduction. In: Halsey, A. H./Lauder, H./Brown, P./Stuart Wells, A. (Hrsg.): Education culture economy society. Oxford: Oxford University Press, S. 1-44.

Beck, U./Bonß, W. (Hrsg.): Weder Sozialtechnologie noch Aufklärung? Analysen zur Verwendung sozialwissenschaftlichen Wissens. Frankfurt a. M.: Suhrkamp.

Biewer, G./Luciak, M. (2010): Der internationale Vergleich in der Sonderpädagogik. In: Waterkamp, D. (Hrsg.): Enzyklopädie Erziehungswissenschaften Online, Vergleichende Erziehungswissenschaft. Weinheim/München: Juventa. DOI: $10.3262 /$ EEO05100093

Bourdieu, P. (1998): Vom Gebrauch der Wissenschaft. Für eine klinische Soziologie des wissenschaftlichen Feldes. Konstanz: UVK.

Bucchi, M. (2010): Visible Scientist. In: Hornig Priest, S. (Hrsg.): Encyclopedia of Science and Technology Communication. Thousand Oaks, CA: SAGE, S. 932933. 
Cowen, R. (2014): Ways of knowing, outcomes and 'comparative education': be careful what you pray for. In: Comparative Education 50(3): 282-301.

Dunwoody, S. (2008): Science journalism. In: Bucchi, M./Trench, B. (Hrsg.). Handbook of Public Communication of Science and Technology. London: Routledge. S. 15-26.

Drori, G. S./Meyer, J. W. (2006): Scientization: Making a world safe for organizing. In: Djelic, M.-L./Sahlin-Andersson, K. (Hrsg.): Transnational governance: Institutional dynamics of regulation. Cambridge: Cambridge University Press, S. 3152.

Franzen, M./Rödder, S. (2013): Die Herstellung und Darstellung von Wissen unter Medialisierungsbedingungen. Eine vergleichende Betrachtung von Mathematik, Zeitgeschichte und Molekularbiologie. In: Grande, E./Jansen, D./Jarren, O./Rip, A./Schimank, U./Weingart, P. (Hrsg.): Neue Governance der Wissenschaft. Reorganisation - externe Anforderungen - Medialisierung. Bielefeld: Transcript Verlag, S. 337-361.

Gardner, J./Gallagher, T. (2007): Gauging the Deliverable? Educational Research in Northern Ireland. In: European Educational Research Journal 6(1): 101-114.

Gibbons, M./Limoges, C./Nowotny, H./Schwartzman, S./Scott, P./Trow, M. (1994): The new production of knowledge. The dynamics of science and research in contemporary societies. London: Sage.

Goodell, R. (1977): The Visible Scientist. Boston/Toronto: Little, Brown and Company.

Grande, E./Jansen, D./Jarren, O./Schimank, U./Weingart, P. (2013): Die neue Governance der Wissenschaft. Zur Einleitung. In: Grande, E./Jansen, D./Jarren, O./Rip, A./Schimank, U./Weingart, P. (Hrsg.): Neue Governance der Wissenschaft. Reorganisation - externe Anforderungen - Medialisierung. Bielefeld: Transcript Verlag, S. 15-45.

Grek, S. (2009): Governing by numbers: the PISA 'effect' in Europe. Governing by numbers: the PISA 'effect' in Europe. In: Journal of Education Policy 24(1): 2337.

Hitzler, R. (1994): Wissen und Wesen des Experten. Ein Annäherungsversuch - zur Einleitung. In: Hitzler, R./Honer, A./Maeder, C. (Hrsg.): Expertenwissen: Die institutionalisierte Kompetenz zur Konstruktion von Wirklichkeit. Opladen: Westdt. Verl., S. 13-30.

Landri, P. (2015): World of Educational Standards. Complex interplays between sociologies of education. In: Lawn, M./Normand, R. (Eds.): Shaping of European Education. Interdisciplinary approaches. London/New York: Routledge, S 81-96.

Lawn, M./Keiner, E. (2006): Editorial - The European University: between governance, discipline and network. In: European Journal of Education 41(2), S. 155167.

Liegle, L. (2010): Der internationale Vergleich in der Pädagogik der frühen Kindheit. In: Waterkamp, D. (Hrsg.): Enzyklopädie Erziehungswissenschaften Online, Vergleichende Erziehungswissenschaft. Weinheim/München, Juventa.

Lindgard, B./Martino, W./Rezai-Rashti, G. (2013): Testing regimes, accountabilities and education policy: commensurate global and national developments. In: Journal of Education Policy 28(5): 539-556.

Martens, K. (2007): How to become an influential actor - The 'comparative turn' in OECD education policy. In: Martens, K./Rusconi, A./Leuze, K. (Hrsg.): New 
Arenas of Education Governance. The Impact of International Organizations and Markets on Educational Policy Making. London: Routledge, S. 40-56.

Mau, S. (2017): Das metrische Wir: Über die Quantifizierung des Sozialen. Berlin: Suhrkamp Verlag.

Nóvoa, A./Yariv-Mashal, T. (2003): Comparative research in education: A mode of governance or a historial journey. In: Comparative Education 39(4): 423-438.

Normand, R. (2010): Expertise, networks and indicators: The construction of the European strategy in Education. In: European Journal of Education 9(3): 407421.

Normand, R. (2016): The Changing Epistemic Governance of European Education. The Fabrication of the Homo Academicus Europeanus? Switzerland: Springer International Publishing.

Parreira do Amaral, M./Hornberg, S./Kotthoff, H.-G. (2015): Internationale und Vergleichende Erziehungswissenschaft zwischen Traditionen und aktuellen Herausforderungen. In: Tertium Comparationes 21(1): S. 1-5.

Peters, H. P./Heinrichs, H./Jung, A./Kallfass, M./Petersen, I. (2008): Medialisierung der Wissenschaft als Voraussetzung ihrer Legitimierung und politischen Relevanz. In: Mayntz, R./Neidhardt, F./Weingart, P./Wengenroth, U. (Hrsg.): Wissensproduktion und Wissenstransfer - Wissen im Spannungsfeld von Wissenschaft, Politik und Öffentlichkeit. Bielefeld: transcript Verlag, S. 269-292.

Petersen, I./Heinrichs, H./Peters, H. P. (2010): Mass-mediated expertise as informal policy advice. In: Science, Technology, \& Human Values 35(6): 865-887.

Pettersson, D./Popkewitz, T. S./Lindblad, S. (2016): On the Use of Educational Numbers: Comparative Constructions of Hierarchies by Means of Large-Scale Assessments. In: Espacio, Tiempo y Educación 3(1): 177-202.

Pilz, M. (2011): Der internationale Vergleich in der Berufs- und Wirtschaftspädagogik. In: Waterkamp, D. (Hrsg.): Enzyklopädie Erziehungswissenschaften Online, Vergleichende Erziehungswissenschaft, Weinheim/München, Juventa. DOI: 10.3262/EEO05110160.

Power, M. (2004): Counting, control and calculation: Reflections on measuring and management. In: Human Relations 57(6): 765-783.

Rieger-Ladich, M. (2007): Akzeptanzkrisen und Anerkennungsdefizite: Die Erziehungswissenschaft als subalterne Disziplin? In: Ricken, N. (Hrsg.): Über die Verachtung der Pädagogik. Analysen - Materialien - Perspektiven. Wiesbaden: VS Verlag, S. 159-182.

Proske, M. (2002): Pädagogisierung und Systembildung. Das Pädagogische im gesellschaftlichen Umgang mit dem Dritte-Welt-Problem. In: Zeitschrift für Erziehungswissenschaft 5(2): 279-298.

Schimank, U. (1995): Für eine Erneuerung der institutionalistischen Wissenschaftssoziologie. In: Zeitschrift für Soziologie 24(1): 42-57.

Schröder, B. (2016): Vergleichende historische Religionspädagogik - methodologische Überlegungen. In: Zeitschrift für Pädagogik und Theologie 68(2): 238-251.

Schützeichel, R. (2008): Universitäten, Wissen, Expertise - Soziologische Überlegungen $\mathrm{zu}$ epistemischen Konstellationen und Regimen. In: Jäger, W./Schützeichel, R. (Hrsg.): Universität und Lebenswelt. Festschrift für Heinz Abels. Wiesbaden: VS Verlag, S. 46-83. 
Sirota, R./Zay, D./Lawn, M./Keiner, E. (2002): European Networking in Education. Report on Roundtable 2, held at ECER 2001, Lille, 7 September 2001. In: European Educational Research Journal 1(3): 566-592.

Stehr, N. (1994): Knowledge Societies. London u.a.: Sage.

Tenorth, H.-E. (2014): Politikberatung und Wandel der Expertenrolle oder: Die Expertise der Erziehungswissenschaft. In: Fatke, R./Oelkers, J. (Hrsg.): Das Selbstverständnis der Erziehungswissenschaft: Geschichte und Gegenwart. Weinheim; u.a.: Beltz Juventa, (Zeitschrift für Pädagogik, Beiheft; 60), S. 139-171.

Treptow, R. (2010): Vergleichende Sozialpädagogik/Sozialarbeit. In: Waterkamp, D. (Hrsg.): Enzyklopädie Erziehungswissenschaften Online, Vergleichende Erziehungswissenschaft, Weinheim/München, Juventa. DOI: 10.3262/EEO05100046.

Waldow, F. (2015): Coda: Hat sich die Vergleichende Erziehungswissenschaft zu Tode gesiegt? Wozu brauchen wir sie noch? In: Tertium comparationis 21(1): 130-139.

Wehling, P. (2007): Wissensregime. In. Schützeichel, R. (Hrsg.). Handbuch Wissenssoziologie und Wissensforschung. Konstanz: UTB, S. 704-712.

Weingart, P. (1998): Science and the media. In: Research Policy 27(9): 869-879.

Weingart, P. (2015): Die Entstehung einer Wissenspolitik. In: Weingart, P./Carrier, M./Krohn, W. (Hrsg.): Nachrichten aus der Wissensgesellschaft. Analysen zu Veränderung von Wissenschaft. 2. Auflage, Weilerswist: Velbrück Wissenschaft, S. 315-322.

Weingart, P./Schulz, P. (2014): Einleitung: Das schwierige Verhältnis zwischen Wissenschaft, Öffentlichkeit und Medien. In: Weingart, P./Schulz, P. (Hrsg.): Wissen - Nachricht - Sensation: Zur Kommunikation zwischen Wissenschaft, Öffentlichkeit und Medien. Weilerswist: Velbrück Wissenschaft, S. 9-18.

Weingart, P./Schwechheimer, H. (2015): Institutionelle Verschiebungen der Wissensproduktion - Zum Wandel der Struktur wissenschaftlicher Disziplinen. In: Weingart, P./Carrier, M./Krohn, W. (Hrsg.): Nachrichten aus der Wissensgesellschaft. Analysen zu Veränderung von Wissenschaft. 2. Auflage, Weilerswist: Velbrück Wissenschaft, S. 41-54.

Wigger, L./Marotzki, W. (2008): Einleitung. In: Marotzki, W./Wigger, L. (Hrsg.): Erziehungsdiskurse. Bad Heilbrun: Klinkhardt, S.7-14.

Zapp, M./Powell, J. J.W. (2016): How to construct an organizational field: Empirical educational research in Germany, 1995-2015. In: European Educational Research Journal 15 (5): 537-557. 


\title{
14 Rethinking education in times of globalization - but where to start the rethinking?
}

\author{
Iris Clemens, Tanu Biswas
}

Dysfunctionality of education - or to be more precise time spent in institutions meant to be installed for the purpose of education - is a problem that attracts attention globally. Apparently reports and studies show that in many contexts, not only due to bad conditions such as lack of facilities, absence of teachers (Abadzi 2009; De and Dreze 1999; De et al. 2011) etc., but also because of the inadequate form and content of education, children leave school after years of boredom and helpless disciplinary actions without the ability to read, write and/or be able to contribute a meaningful share to their community (Jeffrey et. al. 2004, 2005; Pillai 2013). Contrary, the socialisation in these institutions can alienate the young community members from their community and leave them without any competencies, be it for subsistence economy on the one hand or white-collar employment in global economy on the other (ibid.). Beside this urgent need for transformations in the given educational sector, it seems to be very difficult if not impossible to even think of alternative forms of education that are substantially different to the hegemonic concept of education found globally. In the following pages, we analyse more detailed the underlying concept of universal education and why thinking of alternative ways in education is so difficult, but urgent. Our assumption is that the very idea of singularity is part of the problem.

\subsection{The absent invisible quality or why to drink warm Coke in the desert}

In the beginning of his movie The Pervert's Guide to Ideology, Slavoj Zizek (2012) explains the awaking of specific desires such as drinking warm coke in the hot desert with the ability to add an absent invisible quality to a commodity. But were does this absent invisible quality come from? Any product is relational and refers to something other than itself - be it that the product is 
linked to an ideology as Zizek suggests or the many other thinkable ways of connections between products and social contexts and ideas. Anything that is made relates to a story. The story is an essential part of the product; the object is not the object without that meaning. The object and its meaning emerge in a certain context, as any concept or meaning pattern is coupled with the social figurations in which it emerged in the realm of social evolution. In systems theory, this constellation is described as structural coupling from semantics (meaning) and social structures (society) (Luhmann 1998). Both, semantics as much as society, provide each other basic necessities in the course of social evolution and are therefore interdependent. Ideas, concepts or any kind of meaning have to sooner or later show connectivity to the society wherein they emerged. Ideas and concepts which can describe or explain certain phenomena or circumstances sufficiently could be used as long as they are plausible for the actors: it might not turn-off your thirst, but it is cool/fashionable etc. to drink hot coke in the dessert and you can show a certain belonging.

But objects as much as the stories that add meaning to them can travel from one network to another, and they travel even more and faster under the conditions of globalization and digitalization. So do ideas and tied practices of education, which have to sooner or later show their connectivity to society in these new contexts. And it seems that they partly fail this test. Of course, there are long traditions explaining why concepts travel like the approach of externalisation (Schriewer 1987) or showing what happens with educational concepts if they do, as expressed in the terms of lending and borrowing (Steiner-Khamsi 2004). Another favoured concept is that of diffusion, leading to a homogenization at least on the surface: ideas and concepts that are on the market are taken up e.g. to show the modernity of a state (Meyer/Ramirez 2000). Indeed, there seem to be a lot of hints that it is reasonable today to speak about an ongoing homogenization of educational concepts as much as practices. A powerful factor here is the ongoing global expansion of the logic of economy in all parts of life: education is not only seen as an increasingly profitable business worldwide as Global Educational Industry (Verger et al. 2016) followed by privatization and economization, but due to standardization and the import of management logics and tools it is more and more also run like one, including controlling, frequent testing, monitoring, division in service centre and so on.

A so to say pure diffusion of education can be illustrated vividly with the painting American Progress (Gast 1873) from times of the settlers (see illustration 1). Here, the female (lightly covered) progress, looking like a Christian angle floats to the West with a school book in her hand and accompanied by the railway, laying railway tracks while passing and exile the "noncivilized' with her light (or enlightment?). What can be seen very good here is that 'the progress' and education are obvious foreign bodies in the space 
they enter. They seem to have no precursor in the context which they penetrate, they diffuse indeed like a gas and connect to nothing pre-existing, building no hybrids with the context but simply replacing what has been there before. The pre-existing can only flee.

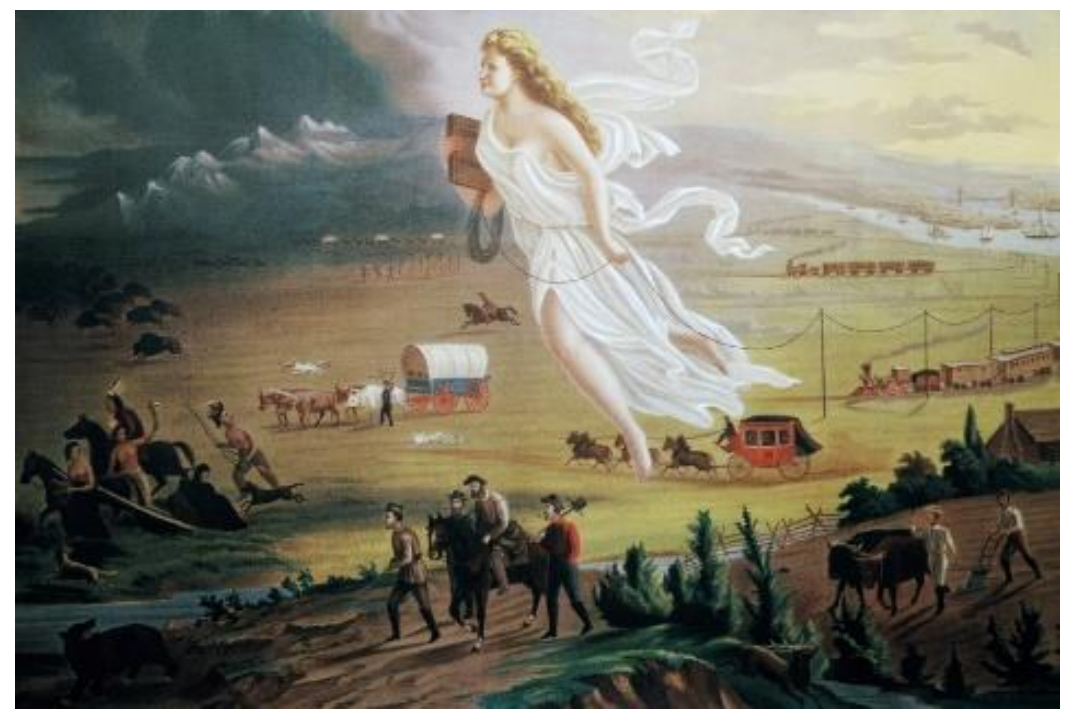

Illustration 1: Painting “American Progress” (Gast 1873)

Educational concepts, institutions and practices are favoured examples when it comes to descriptions of processes of diffusion by the neo-institutionalists. Some specific educational concepts emerged in the Euro-North-American context spread globally, it says. Neo-institutionalists speak of mimicry on the surface (dominant institutions and concepts were adopted as mythically inflated concepts of modernity, leading to institutional isomorphy) and include resistance in local organizations against these concepts, leading to homogenization on the outward and cultural differences remain in the operating processes.

Very obvious, besides all the talk on plurality a certain idea of a universal education can be found, be it implicit in the logic of large scale assessments such as PISA (a single global literacy concept for all) or in programs of the world bank etc. as well as in the concept of globally applicable human capital. It seems one can find leavings of idea fractions by the enlightment: the one, ostensibly progressive, good and sublime (very white, following the picture above) education for all that will finally lead to a better life for all in 
the world. In the following, we will analyse this idea of singularity of education, referring to employability as one of the recent core arguments for standardization (and therefore also homogenization) of education and related reforms in the educational sector.

\subsection{Global, not universal - the problematic assumption of singularity in education: the case of employability}

The problem can be firmly grasped using the often-quoted prognosis by the Boston Consulting Group, in which the idea of a singular education and its global applicability become obvious: In 2020, the rest of the world will face a deficit of 47 million working people while India will have a surplus of 56 million (Kumar 2016; Khare 2016), the group estimates in a report. Only in stepping back and reflecting about the very fact that these two numbers are opposed one sees the logic behind. Obviously in putting these numbers in relation to each other, it is suggested that a) there is indeed a relation after all and further $b$ ) that here lays a solution for a problem. Following this logic, one must make sure as soon as possible to provide these 56 million Indians with a universally conceptualized education to compensate for the global shortage. Believing in a positive effect of global 'development' through economic growth, and education playing an important part in this process - a fact Resnik (2006) called the 'education-economic-growth black-box' to point out that no one can really say if or how it works - this action would help everyone: "Filling the skill gaps in both the domestic and the global arena is crucial to sustain the economic growth", Kumar states (2016, p. 65; also Pilz 2016, p. 344). Implicit in this calculation we find the assumption of a singular education with universal connectivity: wherever you are educated, once that education is standardized you can go for work wherever you want (or have to). And this singular education is causally connected with economic growth, or more precisely: once established globally, this one singular education will lead to one specific modernity e.g. that of the Euro-North-America model including white collar jobs and a certain form of employment, and that this will be good for anyone.

So much for the logic of growth and universality: But does this ideology fit with reality? What is the state of the art of global employability? The enormous unemployment rates of academics for example in India (Gilbertson 2017), but also in parts of Africa such as e.g. Ethiopia (Mains 2012), Nigeria (Masquelier 2013) etc. however speak of a different reality and deliver no support for a causal relationship between growth in education and economy or at least between education and employment or economic security. There are not enough white-collar jobs, such specific employments invented in 
Euro-North-America for degree holders. A big contradiction in the argumentation becomes visible.

Studies "indicate that across many settings, young people feel that formal schooling has not prepared them well for productive life. This failure is sometimes referred to as a 'crisis of modernity' - the failure of state systems of education to deliver equally on the promises of development: jobs, income, health, wealth, and social security." (Stambach/Hall 2017, p. 34 , accentuation by authors)

Nevertheless, there are two main strategies and argumentations observable regarding how educational systems globally should or do handle the transformations related to globalization and the corresponding consequences like heavy critique on the educational systems. Very often they are assumed to be interrelative or additive. On the one side we find the call for expansion: more educational institutions should educate more humans of all ages in more ways. The other strategy demands quality of education and adaption to the world of work, expressed e.g. through the term of employability. In line with the debate on human capital, an education should be provided, that leads more or less directly to employability in a specific economic field worldwide. With the allocation function of education the preparatory role of school for job market has been pointed out (Luhmann 2002), and education is an important part of what is called human capital. This human capital is thought of as universal, as it is applicable globally. Godfather of this idea is the World Bank (e.g. Khare 2016), and universality of education is a precondition for this concept. But besides these ideologies until today, so-called modern educational systems produce a lot of degree holders who do not find an adequate position on the job market (Berlant 2011; Fernandes 2000; Gilbertson 2011; for the U.S. Chamie 2017). Having that in mind it is difficult to understand why worldwide across-the-board an expansion of an apparently problematic educational system is propagated, and alternative approaches are overseen, neglected or not even thought of.

The rentability of high expenses for education especially for socioeconomically weak families is questionable and not as obvious as suggested. Due to processes discussed under the term of educational inflation this is true not only for India but globally, observable e.g. in the United States as well (Chamie 2017; Consumer Financial Protection Bureau 2017). Taking the phenomenon of the American educational bubble helps to bring the problem to a global stage. Student debts there sum up to unbelievable 1 trillion dollars, and a lot of these students will never be able to pay these debts back (Rossi 2014). Half of all college degree holders under 25 years in the U.S. are unemployed or not employed in an appropriate position (ibid.). Especially for socio-economically weak families the sometimes enormous investment in education often does not pay back and does not lead to a reasonable employment. In contexts like India to which the Boston Consulting Group refers, additionally another problem arises with the enrollment in the so-called mod- 
ern education sector. Also, due to liberations in the state sector white-collar jobs are rare and difficult to attain, especially for persons from lower parts of the society (for Germany see Friedrich 2008) as jobs are awarded through networks from which they are excluded (Gilbertson 2017) and cast still plays a dominant role. On the other side, being engaged in the formal educational sector means being absent in the community and the subsistence economy, for example the family business or agriculture (see Maurus 2019 in this volume). The socialization in the formal education system leads to a gap with regard to the own community and its knowledge resources: who is not there cannot learn. These situations become critical if the degree holders can no longer fit into their communities - be it because of a transformed habitus and / or lack of knowledge etc. - but are also not able to find suitable employment (Jeffrey et. al. 2005). Another misleading, similar trend caused by formal education is the phenomenon of waiting: students who fail to get the most wanted government jobs for example in India (Jeffery 2010) or Bhutan (Roder 2017) decide to rather wait for those employments without knowing if they ever will get one instead of doing something else. Here again, the strategy works rather for the privileged who might sooner or later get jobs through their networks. For the underprivileged yet another discrimination is waiting, as they most probably just get older. Taking these different developments of dysfunctional education into account, some talk about a lost generation due to education here. This dysfunctionality of the formal educational system stays under-reflected and is not sufficiently considered by the demand for more or employability explained above. Education might be part of the problem it wants to solve (Clemens 2016, 2011). In opposition, the very idea of employment might be part of the problem too, as it refers to specific societal forms (wherein it emerged) that are not given in other contexts. Additionally, the focus on employment covers the informal work done especially by women (Sen 1999) which will never appear in any statistics, but contributes massively to the survival of families all over the world. And as Amartya Sen (1999) has rightly pointed out: one can be employed, but still poor in opportunities as the critical factor is to have opportunities to thrive. The idea of employability and the function education plays in it is structurally coupled with specific societal forms of Europe and North-America, and no one can say if in societies such as India or states in Africa similar contexts will ever emerge, once we take multiple modernities or alternative ways of social evolution into consideration. At least for now a mismatch can be stated.

In consequence, there are good reasons to ask for the general connectivity of the specific type of formal education going global (not universal) to different contexts, especially if economic aspects and employability chances - or broader: the world of work - are considered. With the quest of employability the question arises: in which world of work should one be integrated? Taking the Indian example again: the informal sector generates 60 percent of the 
country's economic output (Pilz 2016, p. 16) and more than 90 percent (!) of all workers are employed there (ibid.; Palanithurai 2016). India is an agriculturally shaped country with nearly 70 percent of the population living in rural areas (Majumdar 2016, p. 10). 57 percent of working men and 62 percent of working women in the rural areas are self-employed (Palanithurai 2016, p. 145). This partly mirrors global circumstances, as peasants provide round about 60 percent of food production worldwide ${ }^{1}$, not the big and influential global food companies who work on a much more resource intensive basis and where relatively less (white-collar) jobs are available. In consequence, one can see that the world of work for which, according to the human capital thesis, the standardized formal education should prepare, looks quite different in distinct contexts than so-called universal standards suggest (see also Clemens 2017). The very concept of employability itself does not have much connectivity to these social structures. It follows that, especially if entrance to the world of work is the goal (Kalam/Rajan 2016, p. 209-210; Srivastava 2017 , p. 29), an education assimilated mostly to urban white-collar jobs and related employments does not convince at all. The warm coke does not taste in the hot desert for a good reason.

So why do educational concepts and practices that are very openly dysfunctional for a great part of the corresponding societies, assert themselves? Communication theory and discussions on 'world society' (Stichweh 2000; Meyer/Ramirez 2000) have arguments to explain this phenomenon. In the last section however, we want to stress upon another aspect, pointing out some structures of logic and their consequences.

\subsection{Plurality on all levels as the starting point for rethinking education}

As we have seen, the idea of universal education is closely interwoven with the idea of economic growth, and both have played a tremendous part in the concept of development. For some good reasons, the idea is under pressure though. However, in the classical idea of development there is only one possible, positively connoted future. It is more or less a copy of the Euro-NorthAmerican economy and life style worldwide and a global extension of the same. This is also visible in the equation of the global lack of working people

1 According to the Food and Agriculture Organisation (FAO) of the United Nations, e.g. "small-scale and family farmers produce 80 percent of the food supply in sub-Saharan Africa and Asia“, see http://www.fao.org/3/a-i7658e.pdf [Access: 1 October 2018]. 
on the one side and the surplus in India on the other mentioned above. This idea of a singular future for all is based on assumptions of wealth through economic growth and the belief in white-collar employments of a specific way. Coupled with these expectations is a specific concept of education that should serve these goals.

The problem starts when it becomes clear that there are not (and maybe never will be) masses of these modern white-collar employment jobs around the world for the masses of graduates produced by the education systems fuelled by the ideology of more. And is it right to assume that millions of working people from one part of the world would really fill the global gap of working force somewhere else? Is there an education that is independent and applicable to any foreign context? Already the lack of connectivity of the given education within the own national contexts (like mentioned above for India and the U.S.) challenges the idea. The assumption, basis for the human capital thesis as well, that this capital can be used in any given social or cultural context is more than questionable. We can state that social mobility through education in general as well as education for all as the problemsolver for global crises is nothing but a fiction that might come true for some but doesn't necessarily have to be true for all (or even a majority). Not even one percent of degree holders in engineering science in India are assumed to be 'readily employable' says Khare (2016, p. 110). Children leaving educational institutions after years as functionally illiterate, indicates another reality as well (UNESCO, in Verger et al. 2016, p. 199). Majority of the world of work in India for example - the informal, rural, subsistence economy driven sector - is simply excluded from these educational stories. Unfortunately, this devaluates practices and knowledge resources of the majority population. This is extremely problematic taking into account aspects such as sustainability, plurality of modernity (or multiple modernities, Eisenstadt 2000) and alternative social transformations or developments. We see here that one of the basic problems for rethinking education is the still dominant concept of singularity, be it singularity of modernity, so called development, education (and their interrelatedness) or anything else. But where might this preference for singularity come from? And is it without alternative? And would a rethinking not have to start beyond such a thinking-pattern?

\subsubsection{Somehow singularity is true (T)}

Diversity, multiplicity, hybridization and simultaneity of contradicting processes and developments are characteristic for the post-modern times we live in. Thus, it is remarkable that singularity and duality still constitute dominant patterns of thinking and explaining. To highlight the underlying argument, we look very briefly for an alternative thinking pattern and ask for inferences 
for thinking and acting in hypercomplex, often contradicting worlds. To throw some light upon the how-ness of prevalent thinking with the intention of unveiling the foundational problem of coping with the various and simultaneously operating multiplicities, the principle of singularity is briefly visited in what follows. The logical foundation of singularity adheres to specific two-valued logic systems: $\mathrm{x}$ is either true $(T)$ or false $(\sim T)$. Such a system of logic can most probably not offer an efficient technology for the re-thinking of effective responses not only to the contemporary problem in the educational sector, but the systematically overheated (Eriksen 2016) or hypercomplex contemporary world at large. It seems highly unfruitful to accept logic as a universal fact primarily because the relationship between human psychology and logic remains unsettled. The debates between the Western and Indian tradition for example have to a large extent focused on this aspect. One can find anti-psychologists from the formal tradition, who did not tolerate that the inclusion of so-called psychological elements (e.g. experience) could be part of logical argumentation. As a result, they continued developing a highly formal code of logical expression. This resistance towards the inclusion of psychological elements in logical expression resulted in 'other' systems such as the Nyaya School of Logic having to constantly justify their status as logic. Based on the case of Nyaya logic in his article Psychologism in Indian Logical Theory, Mohanty (1985) argues that psychologism is not necessarily anti-logical. One could read this at face value as a case for Nyaya logic. Nevertheless, Mohantys' article is just one of the many expressions of a historical struggle for Indian schools of logic to be included in the mainstream, scientific definition of logic.

Formal logic as the epistemological ground for most mainstream sciences uses special symbols to express logical conjunctions of statements. This variety of logic is two-valued and thus it must always be clear if a proposition is true $(\mathrm{T})$ or false $(\sim \mathrm{T})$. Statement $A$ can only be either $(\mathrm{T})$ or $(\mathrm{F})$, never both (T) and (F) implying a co-existing negation e.g. $A$ and $\sim A$, must be false if $A$ is true and vice versa. In case there are two propositions i.e. $A$ and $B$, there are specific rules to determine the truth or falsity of their conjunction. If the statement ' $A$ and $B$ ' is (T), both statements $A$ and $B$ must be (T), in every other case the statement is (F). Similarly, in case of the disjunction ' $A$ or $B$ ', the proposition is only (F), if and only if both $A$ and $B$ are $(\mathrm{F})$, in every other case it is (T). Hence, and this is crucial for our argumentation, this technique of thinking is unable to tolerate contradiction. However, the noncontradictory two-valued characteristic need not be a necessary feature of all logics as seen in the case of Jaina logic (Biswas 2017, p. 98-99). 


\subsubsection{The Jaina Framework of Logic}

Jaina philosophers ${ }^{2}$ hold that reality cannot be expressed in simple and absolute statements (e.g. I am reading this text) as this would simplisticly reduce complexity of being. A valid claim of knowledge, according to the Jainas, is described through seven propositions which encapsulate the multifaceted nature of a phenomenon. Further, each proposition should be explicit about its conditional character and therefore begin with the term somehow or in a certain sense e.g. somehow I am reading this text. Although in principle everything can be seen from infinite perspectives since each of the propositions can be further analyzed from seven standpoints, Jainas hold that the seven standpoints in themselves cannot be reduced or increased further. The physical phenomena of doing something which resembles reading would be adequately described through the following set of seven standpoints:

Somehow, I am reading. $(+)$

Somehow, I am not reading. (-)

Somehow, I am both reading and not reading. (+ . -)

Somehow, this is indescribable. (0)

Somehow, I am reading and this is indescribable. $(+.0)$

Somehow, I am not reading and this is indescribable. $(-.0)$

Somehow, I am and I am not reading and this is indescribable. (+ . . . 0)

While through a two-valued logic perspective 'contradiction' assumes the epistemological status of a problem-to-be-solved, the inclusion of somehowness into the logical thought-scape doesn't produce such problems. Russell's Paradox $^{3}$ for example was partly a result of a logical framework incapable of coping well with contradictions. However, it is the strict adherence to a twovalued system that renders contradictions into problems-to-be-solved in the first place. And this might be part of the problem: this technique of thinking grounded on dual thinking and orientated towards singularity, creates patterns of how to think, observe, define problems and solve them. It is not surprising then that within this framework itself only one system of logic is universally true. While instead of falsehood they give another truth-value to

2 Jainism is one of the six recognized schools of classical Indian Philosophy that emerged paral lely to Buddhism in approximately 6th B.C. They developed a non-absolutist philosophical paradigm in order to explain the multi-faceted and complex nature of existence. The pluralistic approach also know as Anekantavada or doctrine of many-sidedness also grounds their ethics of non-violence at all levels including intellectual non-violence (see Shastri 1990 for a detailed presentation of Jaina Epistemology)

3 The paradox, acknowledged as having been discovered by Bertrand Russell in 1901, concerns logic of set and class. The puzzle was: Is the set of all sets, itself a set? If a set of all sets is itself a set, then does it implies that it is member of itself!? This has been a challenging preoccupation for Russell and his colleagues like Frege. 
'contradictory' statements, the Jaina system might somehow not have faced similar issues and could approach questions about the nature of reality from a whole different point of departure. Of course, within the formal two-valued definition of logic, the Jaina system would struggle to qualify as logic - rendering the possibility of a fruitful transcultural exchanges impossible.

The notion of indescribability, as something indeterminate makes room for accommodating the simultaneous occurrence of apparently contradictory phenomena. It also dissolves the linear sequence (e.g. first I am reading, then I am not reading) of interpretations that one seeks refuge in when faced with contradiction. If $\mathrm{X}$ is present and then disappears and comes back into vision, it doesn't create the confusion aroused in one's perception as when one tries 'to make sense' of X being there and not being there at the same time. What bothers the perceiving conscience is the simultaneity of the occurrence which is indescribable. Simultaneity however is indispensable in the project of grasping plurality. ${ }^{4}$

\subsection{Conclusion}

In order to avoid dysfunctionality while thinking about education, we should take plurality and simultaneity more seriously on all levels: on that of everyday socio-culturally differing lived-worlds with regard to the concepts, theories and epistemologies that education is based on, as well as concerning the worlds of works in which individuals have to find their ways to make a living. We pointed out some factors why it is so difficult for us to overcome uniformitarianism as explained by Lovejoy (1948), patterns of thought including enlightment residuums like universality and singularity. Particularly in the case of employability, so dominant in recent discussions in educational science and only at the first look as simplistic as e.g. the human capital concept suggests, shows how important plurality is. If at all, the question should be that of employabilities, or maybe better 'workablenesses', taking into account realities in non-European-North-American or majority world settings.

4 For a further elaborated consideration of the Jaina concepts of indescribability and somehowness see Gokhale (1991, p. 73-81). 


\section{References}

Abadzi, H. (2009): Instructional Time Loss in Developing Countries: Concepts, Measurement and Implications. Washington DC: World Bank.

Berlant, L. (2011): Cruel Optimism. Durham, NC: Duke University Press.

Biswas, T. (2017): Philosophieren mit Kindern über Grenzen hinweg: Eine childistische Perspective. In: Polylog Zeitschrift für Interkulturelles Philosophieren. Sonderdruck 37/2017: Philosophieren mit Kindern weltweit: 89-102.

Chamie, J. (2017): Student Debt Rising Worldwide. In: YaleGlobal Online. https://yaleglobal.yale.edu/content/student-debt-rising-worldwide [Accessed: 06.08.2018].

Consumer Financial Protection Bureau (2017): Snapshot of Older Consumers and Student Loan Debts. https://www.consumerfinance.gov/data-research/researchreports/snapshot-older-consumers-and-student-loan-debt/ 06.08.2018].

Clemens, I. (2016): When the solution becomes part of the problem: the role of education in social conflicts - observations in the Indian context In: Wulf, C. (ed.): Exploring Alterity in a Globalized World. New York: Routledge, pp. 389-400.

Clemens, I. (2011): Polished person or parasite? The implications of education for identities and self concepts and culturally diverse emotional consequences; a social Indian example In: Paragrana 20(2): 168-180.

Clemens, I. (2009): Globale Lösungen im Bildungssystem der Weltgesellschaft? Eine kulturtheoretische Analyse des Best-Practice-Konzepts in der Erziehungswissenschaft. In: Tertium Comparationis 15(2): 108-121.

Clemens, I. (2017): Review of Pilz, Matthias (ed.) (2016): India: Preparation for the world of work: education system and school to work transition. Wiesbaden: VS Verlag für Sozialwissenschaften In: Tertium Comparationis 23(1): 135-141.

De, A./Dreze, J. (1999): Public Report on Basic Education (PROBE) in India. New Delhi: Oxford University Press.

De, A./Kheera, R./Samson, M./Shiva Kumar, A.K. (2011): PROBE revisited: A report on elementary education in India. New Delhi: Oxford University Press.

Eisenstadt, S. (2000): Multiple Modernities. London: Transaction Pub.

Eriksen, T. H. (2016). Overheating - An Anthropology of Accelerated Change. London: Pluto.

Fernandes, L. (2000). Restructuring the new middle-class in liberalizing India. In: Comparative Studies of South Asia, Africa and the Middle East 20(1/2): 88-11.

Friedrichs, J. (2008): Gestatten: Eliten. Auf den Spuren der Mss in liberalizrgen. Hamburg: Hoffman und Kampe.

Food and Agriculture Organization of the United Nations (2017): The State of Food and Agriculture. Leveraging Food. Systems for Inclusive Rural Transformation. Rome. http://www.fao.org/3/a-i7658e.pdf [Accessed: 26.02.2018].

Gast, J. (1873): American Progress. http://schoolingtheworld.org/wpcontent/uploads/2010/11/American-Progress.jpg [Accessed: 26.02.2018].

Gokhale, P. (1991): The Logical structure of Syādvāda. In: Journal of Indian Council of Philosophical Research 8: 73-81. 
Gilbertson, A. (2017): Aspiration as Capacity and Compulsion: The Futures of Urban Middle-Class Youth in India. In: Stambach, A./Hall, K. D. (eds.): Anthropological Perspectives on Student Futures. Youth and the Politics of Possibility. Anthropological Studies of Education. New York: Palgrave Macmillan US, pp.1932.

Jeffrey, C. (2010): Timepass: Youth, class and the politics of waiting in India. Stanford, CA: Stanford University Press.

Jeffrey, C./Jeffery, P./Jeffery, R. (2004): "A Useless Thing!" or "Nectar of the Gods?" The Cultural Production of Education and Young Men's Struggles for Respect in Liberalizing North India. In: Annals of the Association of American Geographers 94(4): 961-981.

Jeffrey, C./Jeffery, P./Jeffery, R. (2005): When Schooling fails: Young Men, Education and Low-Caste Politics in Rural North India. In: Contributions to Indian Sociology 39(1): 1-38.

Khare, M. (2016): Higher Education / University: Taking the Skills March forward in India - Transitioning to the World of Work. In: Pilz, M. (ed.) India: Preparation for the World of Work. Education System and School to Work Transition. Wiesbaden: Springer, pp. 103-140.

Kumar, K. (2016): It is / ITCs: Industrial Training Institutes / Industrial Training Centres. In: Pilz, M. (ed.): India: Preparation for the World of Work. Education System and School to Work Transition. Wiesbaden: Springer, pp. 65-80.

Lovejoy, A. O. (1948): Essays in the History of Ideas. Baltimore: The John Hopkins Press.

Luhmann, N. (1998): Gesellschaftsstruktur und Semantik. Studien zur Wissenssoziologie der modernen Gesellschaft. Bd. 3, Frankfurt/M.: Suhrkamp.

Luhmann, N. (2002): Das Erziehungssystem der Gesellschaft. Frankfurt/M.: Suhrkamp.

Majumdar, S. (2016): Foreword: Reflections on Opportunities and Challenges of Skills Development in India. In: Pilz, M. (ed.): India: Preparation for the World of Work. Education System and School to Work Transition. Wiesbaden: Springer, pp. 7-14.

Masquelier, A. (2013): Teatime: Boredom and the temporalities of young men in Niger. In: Africa 83(3): 470-491.

Maurus, S. (2019): Rethinking the "Global Good" of Compulsory Schooling - Combining Young People's Education and Work for Making a Future in South-West Ethiopia. In: Clemens, I./Hornberg, S./Rieckmann, M. (eds.): Bildung und Erziehung im Kontext globaler Transformationen. Opladen, Berlin, Toronto: Verlag Barbara Budrich, pp. 139-150.

Meyer, J./Ramirez, F. O. (2000): The World Institutionalization of Education - Origins and Implications. In: Schriewer, J. (ed.): Discourse Formation in Comparative Education. Comparative Studies Series, Volume 10, Frankfurt am Main: Peter Lang, pp. 111-132.

Mohanty, J. N. (1985): Psychologism in Indian Logical Theory. In: Matilal, B. K./Shaw, J. L.. (eds.): Analytical Philosophy in Comparative Perspective. Synthese Library (Studies in Epistemology, Logic, Methodology, and Philosophy of Science) Vol. 178. Dordrecht: Springer, pp. 203-211.

Palanithurai, G. (2016): Other Official / Governmental Programmes: Government Initiatives for Preparing Youth for the World of Work. In: Pilz, M. (ed.): India: 
Preparation for the World of Work. Education System and School to Work Transition. Wiesbaden: Springer, pp. 141-168.

Pilz, M. (ed.) (2016): India: Preparation for the World of Work. Education System and School to Work Transition. Wiesbaden: Springer.

Resnik, J. (2006) International Organizations, the "Education-Economic Growth" Black Box, and the Development of World Education Culture. In: Comparative Educational Review 50(2): 173-195.

Roder, D. (2017): "Too Good to Teach": Bhutanese Students and a Hierarchy of Aspirations. In: Stambach, A./Hall, K. (eds.): Anthropological Perspectives on Student Futures. New York: Palgrave McMillan, pp. 33-49.

Rossi, A. (2014): Ivory Tower. Paramount Pictures.

Schriewer, J. (1987): Vergleich als Methode und Externalisierung auf Welt: Vom Umgang mit Alterität in Reflexionsdisziplinen. In: Baecker, D./Markowitz, J./ Stichweh, R./Tyrell, H./Willke, H. (eds.): Theorie als Passion. Frankfurt am Main: Suhrkamp, pp. 629-668.

Sen, A. (1999): Development as Freedom. New York: Oxford University Press.

Shastri, I. C. (1990): Jaina Epistemology. Varanasi: P.V. Research Institute.

Stambach, A./Hall, K. (2017): Anthropological Perspectives on Student Futures. New York: Palgrave McMillan.

Steiner-Khamsi, G. (ed.) (2004): The global politics of educational borrowing and lending. New York: Teachers College Press.

Stichweh, R. (2000): Die Weltgesellschaft. Frankfurt am Main: Suhrkamp.

Verger, A./Lubienski, C./Steiner-Khamsi, G. (eds.) (2016): The Global Education Industry. World Yearbook of Education 2016. New York: Routledge.

Zizek, S. (2012): The Pervert's Guide to Ideology. Zeitgeist Films. 


\section{Verzeichnis der Autorinnen und Autoren}

Nadine Bernhard, Dr. phil., Postdoktorandin am Lehrstuhl Vergleichende und Internationale Erziehungswissenschaften der Humboldt-Universität zu Berlin; Arbeitsschwerpunkte: Institutioneller Wandel von Berufsbildungsund Hochschulsystemen, Transfer von Bildungspolitiken, Internationalisierungs- und Europäisierungsprozesse in der (Hochschul-)Bildung, Strukturen und Praktiken der Differenzkonstruktion an Hochschulen, soziale Ungleichheitsforschung.

Tanu Biswas, M.A., Mphil., Junior Researcher at Department of General Pedagogy, University of Bayreuth; research areas: Childism, Childhoods, Philosophy of Pedagogy; affiliated guest researcher at the Institute for Lifelong Learning, Norwegian University of Science and Technology; Member of Ladakh Studies Association; Tanu has engaged closely with diverse childhoods in India (Ladakh, Goa, Pune District), Italy (Trentino-Alto Adige), Germany (Tübingen City) and Norway (Trondheim City). Her present focus is on suggesting a childist perspective for the pedagogy of philosophy in response to our era of Anthropocene Neoliberalism.

Antje Brock, wissenschaftliche Mitarbeiterin, Arbeitsstelle des Wissenschaftlichen Beraters des UNESCO-Weltaktionsprogramms „Bildung für nachhaltige Entwicklung"; Sprecherin der Early Career Scientists des Deutschen Komitees für Nachhaltigkeitsforschung in Future Earth; Arbeitsschwerpunkte: Bildung für nachhaltige Entwicklung, Gerechtigeitskonzeptionen und Nachhaltigkeit.

Iris Clemens, Dr., Professorin für Allgemeine Pädagogik an der Universität Bayreuth; stellvertretende Vorsitzende der Deutschen Gesellschaft für Netzwerkforschung (DGNet), Principal Investigator des Exzellenzcluster Africa Multiple; Arbeitsschwerpunkte: Globalisierungsprozesse und Implikationen für Bildung, Netzwerktheorie und relationale Perspektiven, Indien, Globale Relationen der Emergenz von Wissen und Ideenevolutionen, Wissens- und Bildungstransformationen in der Weltgesellschaft, kultursensitive Perspektiven auf Epistemologien.

Nadine Etzkorn, M.A. Bildungswissenschaft, arbeitet an der Arbeitsstelle des Wissenschaftlichen Beraters zur Umsetzung des Weltaktionsprogramms „Bildung für nachhaltige Entwicklung“ am Institut Futur der Freien Universi- 
tät Berlin. Ihre Promotion untersucht das Potential von Global Citizenship Education in Auslandsaufenthalten von Austauschstudierenden. Forschungsinteressen: Bildung für nachhaltige Entwicklung, Nachhaltigkeit in Hochschulen, Global Citizenship Education, Internationalisierung von Hochschulen.

Magnus Frank, wissenschaftlicher Mitarbeiter im DFG-Projekt „Die Pädagogik der ,Gülen-Bewegung' - Bildungspraktiken und Biographien in türkischmuslimischen Gesprächskreisen“ am Zentrum für Schul-und Bildungsforschung (ZSB) der Martin-Luther-Universität Halle-Wittenberg; Arbeitsschwerpunkte: Bildung und Islam, migrationsgesellschaftliche Differenz- und Mehrsprachigkeitsforschung sowie Methoden qualitativer Forschung (insb. Ethnographie und Biographieanalyse).

Thomas Geier, PD Dr. habil., z. Zt. Vertretung der Professur für Allgemeine Erziehungswissenschaft: Erziehung und Migration an der Goethe-Universität Frankfurt/Main; Leitung DFG-Projekt: „Die Pädagogik der Gülen-Bewegung - Bildungspraktiken und Biographien in türkisch-muslimischen Gesprächskreisen" am Zentrum für Schul-und Bildungsforschung (ZSB) der MartinLuther-Universität Halle-Wittenberg; Arbeitsschwerpunkte: Migration, Differenz und soziale Ungleichheit in schulischer und außerschulischer Bildung; Pädagogische Professionalität in der Migrationsgesellschaft; Schul- und Unterrichtsforschung sowie Methoden qualitativer Forschung.

Theresa Grapentin-Rimek, M. A., bis April 2019 wissenschaftliche Mitarbeiterin an der Arbeitsstelle des Wissenschaftlichen Beraters zur Umsetzung des Weltaktionsprogramms „Bildung für nachhaltige Entwicklung“ am Institut Futur der Freien Universität Berlin; Arbeits- und Forschungsschwerpunkte: Bildung für nachhaltige Entwicklung, kommunale Bildungslandschaften, Governance, Monitoring von BNE.

Sabine Hornberg, Dr., Professorin für Schulpädagogik und Allgemeine Didaktik im Kontext von Heterogenität an der Technischen Universität Dortmund; geschäftsführende Leiterin des Instituts für Allgemeine Didaktik und Schulpädagogik, Studiendekanin der Fakultät Erziehungswissenschaft, Psychologie und Soziologie, Vorsitzende der Kommission Internationale und Interkulturell Vergleichende Erziehungswissenschaft in der Deutschen Gesellschaft für Erziehungswissenschaft (DGfE); Arbeitsschwerpunkte: Internationalisierung und Transnationalisierung von Bildung, Erziehung und Schule, Europäische Schulentwicklungen, Lehren und Lernen im Kontext von Heterogenität, empirische Bildungsforschung.

Matthias Huber, Mag. phil., Universitätsassistent und Lektor am Institut für Bildungswissenschaft der Universität Wien sowie Dozent an der FH Wien 
und am Zentrum für LehrerInnenbildung; Arbeitsschwerpunkte: Bildung und Emotion, Pädagogische Epistemologie, Lehr-Lern-Forschung, interdisziplinäre Bildungsforschung, neuro- und kognitionswissenschaftliche Perspektiven auf Bildungs- und Entwicklungsprozesse, Schulentwicklung und MixedMethods-Research.

Lydia Kater-Wettstädt, Dr., wissenschaftliche Mitarbeiterin am Institut für Integrative Studien der Leuphana Universität Lüneburg sowie im Robert Bosch Graduiertenkolleg „Processes of Sustainability Transformation“. Arbeitsschwerpunkte: Bildung für nachhaltige Entwicklung, Lehreraus- und -weiterbildung, Bildungsmaterialien, Lernprozesse und Transformation.

Sabrina Maurus, Doktorandin an der Bayreuth International Graduate School of African Studies (BIGSAS) und wissenschaftliche Mitarbeiterin am Lehrstuhl Sozialanthropologie der Universität Bayreuth; Forschungsschwerpunkte: Ethnologie der Bildung, Kindheit und Jugend, Agro-Pastoralismus, Äthiopien.

Marco Rieckmann, Dr., Professor für Hochschuldidaktik, Schwerpunkt Schlüsselkompetenzen, an der Universität Vechta; Nachhaltigkeitsbeauftragter der Universität Vechta; Vertreter der Deutschen Gesellschaft für Erziehungswissenschaft (DGfE) im Council der European Educational Research Association (EERA); Convenor des EERA-Netzwerks „Environmental and Sustainability Education Research“; Sprecher des Deutschsprachigen Netzwerks „LehrerInnenbildung für eine nachhaltige Entwicklung“ (LeNa); Arbeitsschwerpunkte: Hochschuldidaktik, Bildung für nachhaltige Entwicklung, Nachhaltige Hochschulentwicklung, Kompetenzentwicklung und -erfassung.

Corinne Ruesch Schweizer, Erziehungswissenschaftlerin, wissenschaftliche Mitarbeiterin in der Forschungsgruppe Inter- und Transdisziplinarität, Programm Mensch Gesellschaft Umwelt (MGU), Universität Basel; Arbeitsschwerpunkte: (Hochschul-)Bildung für Nachhaltige Entwicklung, Kompetenzen für eine Nachhaltige Entwicklung, beschäftigungspraktische Anforderungen und organisationales Lernen im Kontext Nachhaltiger Entwicklung, interdisziplinäres Arbeiten, nachhaltiger Konsum.

Sarah Schaufler, M.A., wissenschaftliche Mitarbeiterin in der Arbeitsgruppe Internationale und vergleichende Erziehungswissenschaft an der Universität Münster.

Dorothea Schmidt, Bachelorstudentin der Religionswissenschaft an der Universität Leipzig; wissenschaftliche Hilfskraft am dortigen Institut für Orientalistik sowie am Zentrum für Schul- und Bildungsforschung (ZSB) an der Martin-Luther-Universität Halle-Wittenberg innerhalb des DFG Projektes 
„Die Pädagogik der ,Gülen-Bewegung “ - Bildungspraktiken und Biographien in türkisch-muslimischen Gesprächskreisen"; Forschungsinteressen: Rassismusforschung und -theorien, insb. zum antimuslimischen Rassismus sowie soziale Bewegungen und Protest.

Saphira Shure, wissenschaftliche Mitarbeiterin am Center for Migration, Education and Cultural Studies (CMC) an der Carl von Ossietzky Universität Oldenburg; Arbeits- und Forschungsschwerpunkte: Bildung in der Migrationsgesellschaft, Kritische Migrationsforschung, Professionalisierung von Lehrer*innen, Diskurstheoretische Perspektiven sowie interpretative Forschungszugänge.

Mandy Singer-Brodowski, Dr. phil., wissenschaftliche Koordination des nationalen Monitorings an der Arbeitsstelle des Wissenschaftlichen Beraters zur Umsetzung des Weltaktionsprogramms „Bildung für nachhaltige Entwicklung“ am Institut Futur der Freien Universität Berlin; Arbeitsschwerpunkte: Bildung für nachhaltige Entwicklung, Transformatives Lernen, Transformative Wissenschaft.

Nadine Sonnenburg, M.Ed., wissenschaftliche Mitarbeiterin am Lehrstuhl für Schulpädagogik und Allgemeine Didaktik im Kontext von Heterogenität an der Technischen Universität Dortmund; Arbeitsschwerpunkte: Internationalisierung und Europäisierung von Bildung, Heterogenität im Schulsystem, Schulentwicklung, Individuelle Förderung, empirische Bildungsforschung.

Leon Tikly, Ph.D., Professor in Education at the School of Education, University of Bristol. His research interests are in the area of the quality of education in Africa and the achievement of Black and Minority Ethnic learners in the UK. His work is informed theoretically by an understanding of the postcolonial condition in education and a commitment to social and environmental justice.

Theresa Vollmer, M.A., Studium der Pädagogik und Bildungswissenschaft, derzeit wissenschaftliche Mitarbeiterin/Doktorandin am Lehrstuhl Allgemeine Pädagogik, Universität Bayreuth; Forschungsschwerpunkte: aktuelle Bildungskonzeptionen, Netzwerkforschung, Diversität, Indien.

Janne von Seggern, M.A. Sozial- und Kulturanthropologie, 2017-2018 wissenschaftliche Hilfskraft an der Arbeitsstelle des Wissenschaftlichen Beraters zur Umsetzung des Weltaktionsprogramms „Bildung für nachhaltige Entwicklung“ am Institut Futur der Freien Universität Berlin; Arbeitsschwerpunkte: Bildung für nachhaltige Entwicklung, Internationale Zusammenarbeit. 
Marie Zipp-Timmer, M.A., M.Ed., wissenschaftliche Mitarbeiterin am Lehrstuhl für Schulpädagogik und Allgemeine Didaktik im Kontext von Heterogenität an der Technischen Universität Dortmund; Arbeitsschwerpunkte: Transnationale und internationale Schulmodelle, Bildungssystementwicklung und Systemtheorie, Privatschulwesen, Europa in der Schule, empirische Bildungsforschung. 


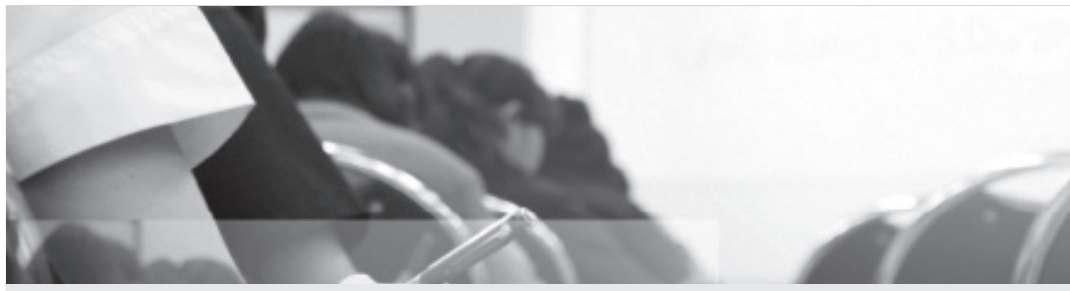

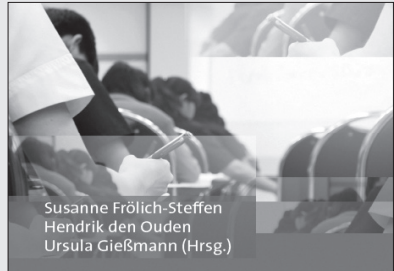

Kompetenzorientiert prüfen und bewerten an Universitäten

Didaktische Grundannahmen, rechtliche Rahmenbedingungen und

praktische Ha

Verlog Barbarer Butrich
Susanne Frölich-Steffen Hendrik den Ouden Ursula Gießmann (Hrsg.)

Kompetenzorientiert prüfen und bewerten an Universitäten

2019 197 Seiten $\cdot$ Kart. $17,90 €(D) \cdot 18,40 €(A)$

ISBN 978-3-8474-2294-5 • eISBN 978-3-8474-1473-5

Prüfungen sind ein Kernstück akademischer Ausbildungen. Sie zeigen die erworbenen Kompetenzen, reihen die Studierenden nach Leistungen und sind für jede Studiengangsorganisation unerlässlicher Bestandteil der Studienplanung. Dieser zentralen Bedeutung akademischer Prüfungen steht ein eklatanter Mangel an Fachliteratur zur Konzeption, Durchführung und Bewertung der Prüfungsformate gegenüber, die im Hochschulalltag aufzufinden oder denkbar sind. Genau diese Lücke soll dieses Buch schließen.

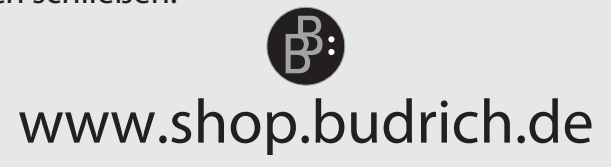


Iris Clemens, Sabine Hornberg, Marco Rieckmann (Hrsg.)

\section{Bildung und Erziehung im \\ Kontext globaler Transformationen}

Schriftenreihe „Ökologie und Erziehungswissenschaft“

der Kommission Bildung für nachhaltige Entwicklung der DGfE

Der Band widmet sich der Reflexion ausgewählter Aspekte von Bildung und Erziehung im Kontext globaler Transformationen. Die Beiträge untersuchen die Transformationsprozesse der Bildung für den globalen Süden sowie Europas Rolle im Kontext dieser Entwicklungen. Zudem zeigen sie, dass die globalen Herausforderungen nicht nur die Frage nach Normen und Werten für Bildung und Erziehung aufwerfen, sondern auch die nach der Veränderung der Erziehungswissenschaft selbst.

Die Herausgeber*innen:

Prof. Dr. Iris Clemens, Universität Bayreuth

Prof. Dr. Sabine Hornberg, Technische Universität Dortmund

Prof. Dr. Marco Rieckmann, Universität Vechta

ISBN 978-3-8474-2174-0

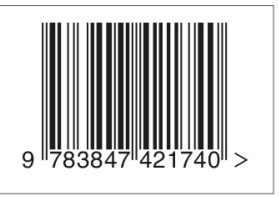

www.budrich-verlag.de 